
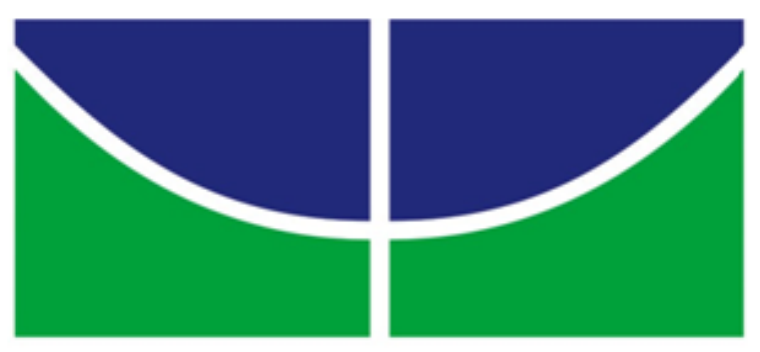

Universidade de Brasília - UnB

Programa de Pós-Graduação em

Patologia Molecular

\title{
Doutorado
}

\section{Modulação da resposta imune inata de polissacarídeos de basidiomicetos na infecção experimental de Cryptococcus neoformans.}

Angelina Maria Moreschi Basso

Orientadora: Anamélia Lorenzetti Bocca

Co-orientadora: Maria Fatima Grossi de Sá

Brasília, DF 


\section{Modulação da resposta imune inata de polissacarídeos de basidiomicetos na infecção experimental de Cryptococcus neoformans.}

Defesa apresentada ao Programa de Pós-Graduação em Patologia Molecular da Universidade de Brasília, como pré-requisito para obtenção de Título de Doutora em Patologia Molecular.

Orientadora: Anamélia Lorenzetti Bocca

Co-orientadora: Maria Fatima Grossi de Sá 
Tese de autoria de Angelina Maria Moreschi Basso intitulada "MODULAÇÃO DA RESPOSTA IMUNE INATA DE POLISSACARÍDEOS DE BASIDIOMICETOS NA INFECÇÃO EXPERIMENTAL DE Cryptococcus neoformans", apresentada como requisito parcial para obtenção do título de Doutora em Patologia Molecular da Universidade de Brasília em 21 de fevereiro de 2017, defendida e aprovada pela banca examinadora abaixo:

Dra. Anamélia Lorenzetti Bocca

Universidade de Brasíllia - UnB

Orientadora

Dra. Maria Fatima Grossi de Sa

Universidade de Brasília - UnB

Embrapa Recursos Genéticos e Biotecnologia

Co-orientadora

Dr. André Moraes Nicola

Universidade de Brasília - UnB

Avaliador

Dra. Andrea Queiroz Maranhão

Universidade de Brasília - UnB

Avaliadora

Dr. Marcelo Porto Bemquerer

Embrapa Recursos Genéticos e Biotecnologia

Avaliador

Dr. Marcio Lourenço Rodrigues

Fundação Oswaldo Cruz

Avaliador

Brasília-DF,

2017 
Autorizo a divulgação e reprodução parcial ou total deste trabalho, seja por meio eletrônico ou convencional, para fins de pesquisa ou estudo, desde que citada a fonte.

Ficha Catalográfica

Faculdade de Medicina

Programa de Pós-Graduação em Patologia Molecular

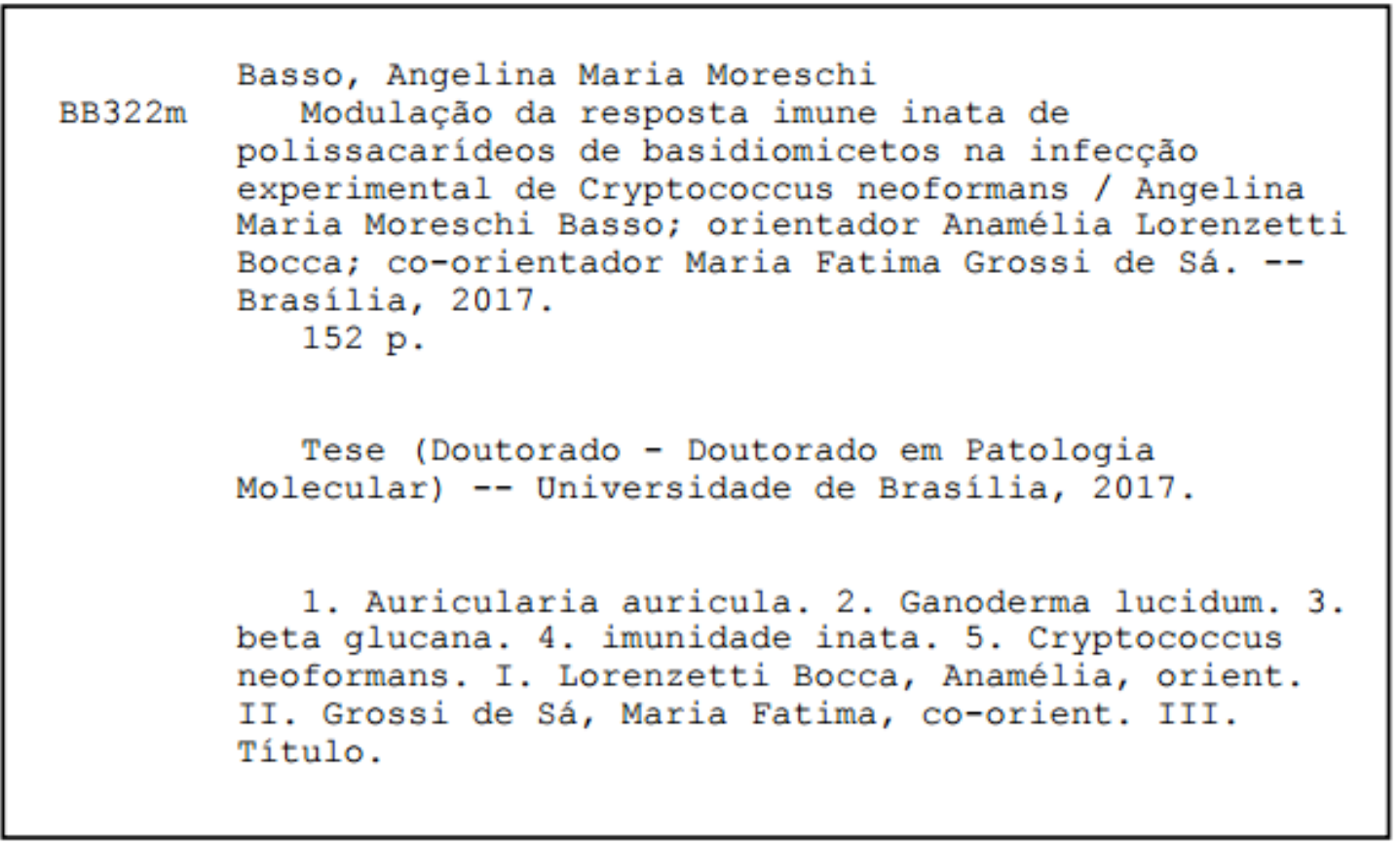

Para citar este documento, utilize:

Basso, A.M.M. Modulação da resposta imune inata de polissacarídeos de basidiomicetos na infecção experimental de Cryptococcus neoformans. Doutora (Doutorado em Patologia Molecular). 152 f. Universidade de Brasília - UnB. 2017. 
"Eu me sentiria mais otimista a respeito de um futuro luminoso para o homem se ele gastasse menos tempo provando que pode superar a natureza e mais tempo saboreando sua doçura e respeitando sua sabedoria".

E.B. White, “Coon Tree”, 1977.

"Não, eu não vou desanimar, não vou deixar de lutar, porque Senhor me é propício, Ele me faz vencedor".

Pode vir o que vier - Crícia e Glaucia Martins 
Dedico este trabalho a Deus, meu pai Bruno (in memorian), minha sempre excepcional mãe Angela e ao meu maravilhoso esposo Tiago. 


\section{AGRADECIMENTOS}

Em primeiro lugar agradeço a Deus, meu Pai e orientador, pela louca e maravilhosa jornada destes 4 anos. Com certeza nada seria possível sem a benção Dele. Espero ter honrado e glorificado Seu nome.

Agradeço ao meu amigo, namorado e esposo Tiago. Jamais pensei que casaríamos durante o doutorado!!! Mas a vida é assim, feita de momentos preciosos pelo qual devemos lutar e o nosso momento chegou. Hoje percebo o quanto fui, sou e sereifeliz ao seu lado. Muito obrigada por todo o apoio, suporte, críticas construtivas, lágrimas e compreensão todas as vezes que cheguei tarde em casa, buscando camundongos no aeroporto ou que você foi me buscar no estacionado do IB a noite. Te amo para sempre!

Também agradeço a minha mãe Angela, por todo o carinho, apoio e suporte apostando nos meus estudos e sonhos. Sempre enxergando a luz quando tudo estava escuro e confuso. Meu porto seguro que me conhece tão bem. Sempre serei grata por tudo mãe!!! Te amo!

Agradeço a minha tia Glaucia, minha madrinha científica, por todo o apoio e sabedoria nos momentos bons e dificeis, com um olhar positivo e protetor. Obrigada por tudo tia!!!

Agradeço a minha família Moreschi e Siqueira, por todo o carinho, torcida e conselhos. Agora sim vamos à luta por um emprego hehehe.

Agradeço MUITO as minhas orientadoras professora Anamélia Bocca e Dra. Fatima Grossi, por proporcionar a realização deste trabalho enigmático e maravilhoso, uma grande oportunidade para a minha carreira científica. Agradeço a confiança depositada em mim. Serei grata por toda a "paciência imunológica" e orientação nesse caminho chamado doutorado. Muito obrigada!

Aos professores membros da banca de qualificação, prof. Andrea, prof. Tatiana e dr. Marcelo. Todas as sugestões e correções foram de imensa valia para este trabalho. Meu muito obrigada pela contribuição. O mesmo para os membros da banca de defesa deste doutorado. Obrigada por aceitarem o convite e dividirem seus conhecimentos e observações.

Também quero agradecer a dra. Arailde Fontes, dra. Vera Polez e ao dr. Thales Rocha, por todas as conversas construtivas e MUITO valiosas, além do apoio na parte inicial deste trabalho. Muito obrigada! 
Agradeço a toda a família UnB, ao Laboratório de Imunologia Aplicada (LIA), começando pelo professor Aldo Tavares, pelos ensinamentos e discussões nos seminários. A professora Larissa, por dividir seus ensinamentos, reagentes e equipamentos. Ao técnico Chiquinho, dando aquela força no nitrogênio ou na autoclave quando eu me esquecia. Aos queridos colegas de trabalho, sempre deixando o dia mais proveitoso e alegre: Marcio, Raffael, Samyra (pelo alto astral contagiante), Karina, Luiza (pelo grande carinho quando cheguei), Paulo, Pedro, Camila (obrigada pela franca amizade), Camilly e Narla (duas meninas de ouro), Fabiana, Guilherme, Thaís (sempre tão ágil e competente), Helena (obrigada por lavar vidraria descontaminada comigo) e lsaque. Obrigada a todos por me ajudarem compartilhando conhecimento, jogando conversa fora ou simplesmente dividindo tarefas. Também gostaria de agradecer ao jivago e Adriana por toda a ajuda com os animais do biotério.

Um agradecimento mais que especial a estes colegas: aos alunos Fernanda, Marco e Fabiana, pelo auxílio e drama nos experimentos de PCR em tempo real. Obrigada à aluna Raquel (LIMI), por me ajudar em um momento tão crucial das análises de citometria de fluxo. Obrigada Marcio, por ajudar na infecção dos animais, Deus te abençoe! Gostaria de agradecer imensamente ao Raffael, obrigada por ajudar uma aluna cabeça dura sem domínio em imuno a aprender um pouco mais dessa área complexa e intrigante, seja na bancada, nas discussões ou dividindo responsabilidades. Espero ser consumidora dos seus produtos um dia hehehe. Também a Marcela (Bioquímica), com toda a ajuda, alto astral e conversas sobre o futuro da nossa profissão, que fizeram diferença na minha visão sobre a universidade. Ao Fabrício e Raissa (LIMPP) por todo o suporte e ajuda no desenho dos primers de RT-PCR e avaliação estatística. Meu obrigada especialmente a todos vocês!

Agradeço também a família Embrapa, ao Laboratório de Interação Molecular Planta Praga (LIMPP) pelo acolhimento nesses 10 anos de caminhada, a Dra. Cristina Mattar pela paciência na minha vida profissional dupla, sempre aceitando meus horários malucos. Aos companheiros de labuta, que se comunicavam comigo mais por e-mail ou whatsapp do que pessoalmente, obrigada pela compreensão, principalmente nos equipamentos sob a minha responsabilidade.

Ao Conselho Nacional de Desenvolvimento Cientifico e Tecnológico - CNPq, pelo apoio financeiro.

E a todos que ajudaram de alguma forma e infelizmente não mencionei....minha gratidão. 


\section{SUMÁRIO}

Lista de abreviaturas............................................................................................iv

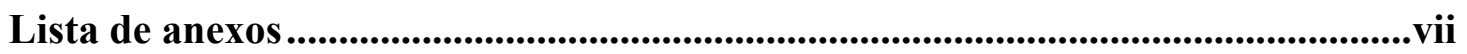

Lista de figuras ...................................................................................................ii

Lista de tabelas ................................................................................................................................xi

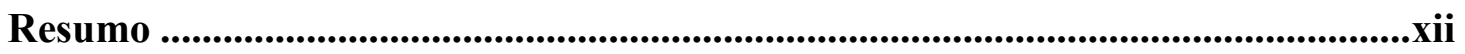

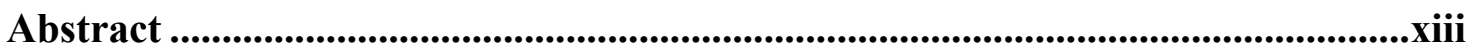

INTRODUÇÃ

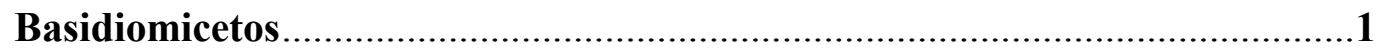

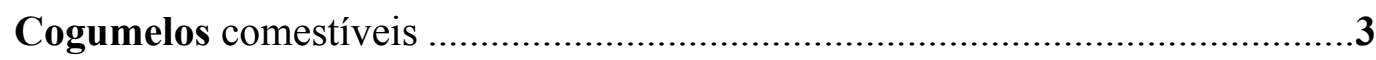

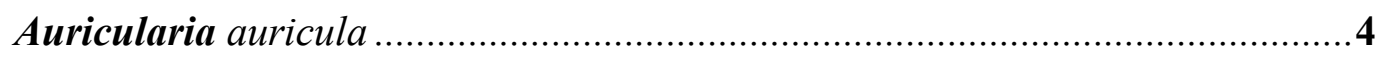

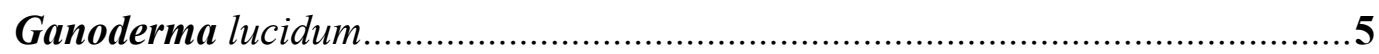

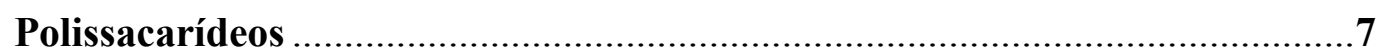

Homo e heteropolissacarídeos de basidiomicetos ...............................................9

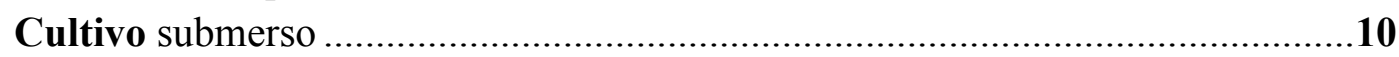

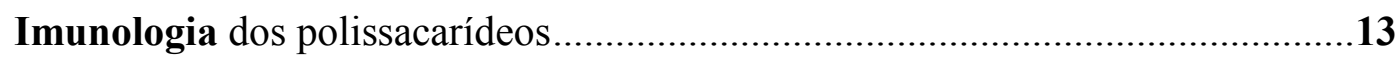

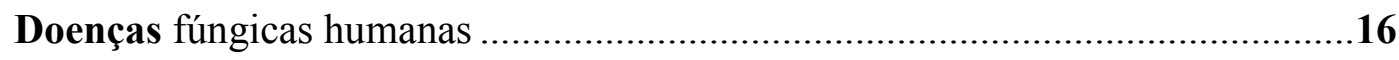

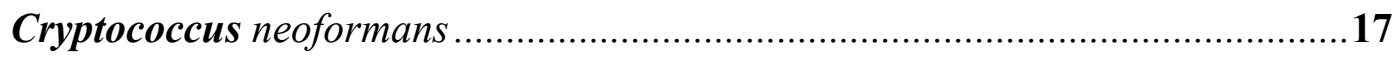

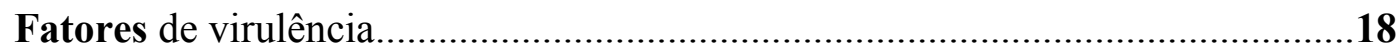

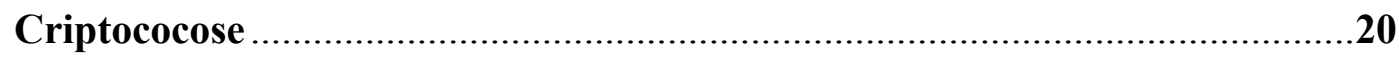

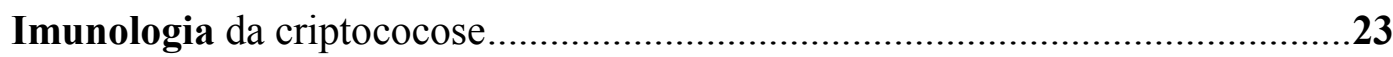

OBJETIVO …........................................................................................................................227

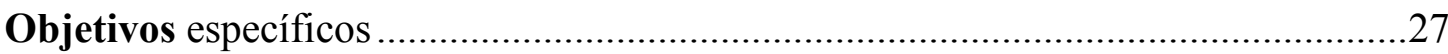

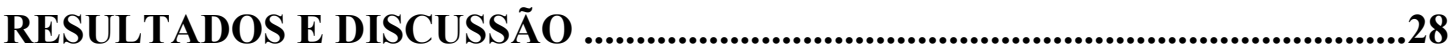

PARTE 1. Caracterização das beta-glucanas obtidas pelos basidiomicetos Ganoderma lucidum e Auricularia auricula .......................................................28

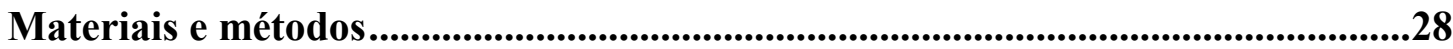

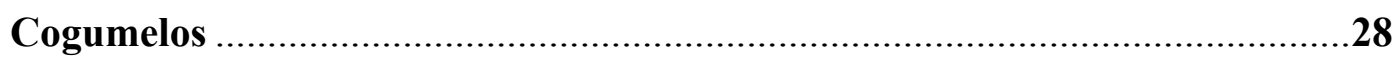

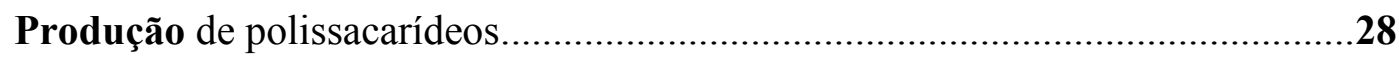

Quantificação de carboidratos....................................................................29

Composição monossacarídica e caracterização estrutural .....................................29

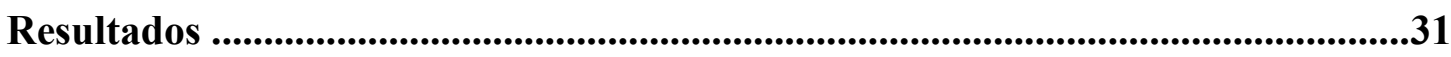

Análise da produção e composição monossacarídica das frações de Auricula auricula

e Ganoderma lucidum .....................................................................................31

Análise estrutural dos polissacarídeos de A. auricula.........................................34

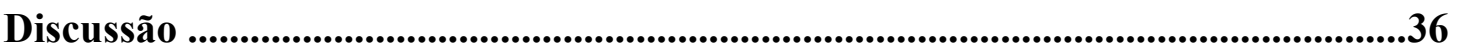


PARTE 2. A atividade imunomodulatória dos polissacarídeos provenientes de Auricularia auricula e Ganoderma lucidum estimularam a secreção de citocinas pró e anti-inflamatória pela ativação dos receptores dectina-1 e TLR2 por via canônica in vitro .39

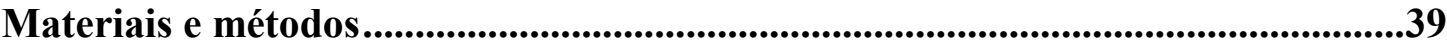

Obtenção e cultivo de células imunes in vitro .......................................................39

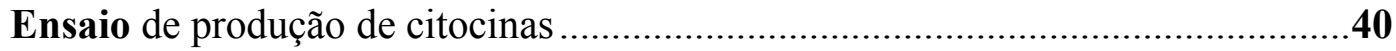

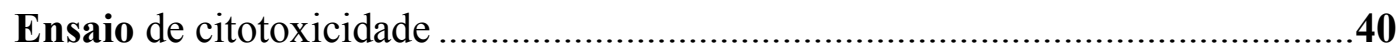

Ensaio de possível presença de LPS na atividade biológica dos cogumelos.........41

Ensaio da importância da internalização das frações na capacidade de estimular a

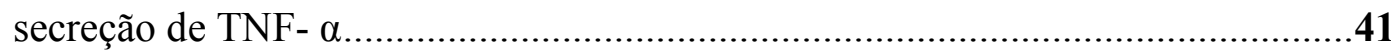

Ensaio de determinação dos receptores de reconhecimento padrão e da sinalização intracelular induzida pelas frações insolúveis e insolúveis

Ensaio da capacidade das frações em estimular a expressão de marcadores de

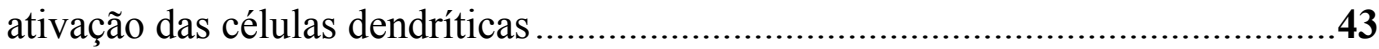

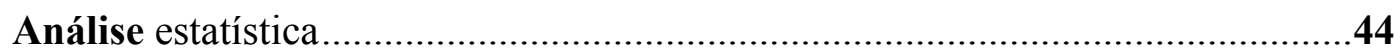

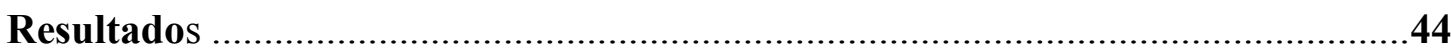

Avaliação de citotoxicidade de polissacarídeos de Auricularia auricula e Ganoderma lucidum .44

Avaliação da produção de citocinas induzida pelos polissacarídeos de Auricularia auricula e Ganoderma lucidum.

Determinação da possível interferência de LPS presente nos compostos de Auricularia auricula e Ganoderma lucidum ................................................48

Avaliação da atividade fagocítica para a sinalização intracelular ........................50 Avaliação da receptores e vias de sinalização de TLRs e CLRs sob estímulo dos polissacarídeos

Avaliação da expressão das moléculas co-estimulatórias Cd80, CD86 e MHCII em células dendríticas após estímulo

PARTE 3. A atividade imunomodulatória dos polissacarídeos oriundos de Auricularia auricula auxiliam a imunidade inata e a sobrevida de animais infectados pelo fungo patogênico Cryptococcus neoformans.

Materiais e métodos .65 Avaliação do índice de adesão e internalização de Cryptococcus neoformans após estímulo com as frações de Auricula auricula e Ganoderma lucidum. 65 
Determinação da atividade microbicida, produção de citocinas e óxido nítrico durante a infecção por Cryptococcus neoformans após estímulo com as frações de Auricularia auricula e Ganoderma lucidum .66

Avaliação da produção de espécies reativas de oxigênio durante a infecção por Cryptococcus neoformans após estímulos de Auricularia auricula e Ganoderma lucidum.

Ensaio de PCR quantitativo em tempo real (qRT-PCR) em células M2 estimuladas com as frações de Auricularia auricula e Ganoderma lucidum e infectadas com Cryptococcus neoformans .68

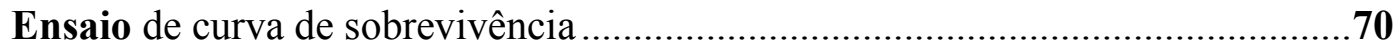

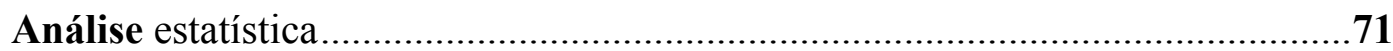

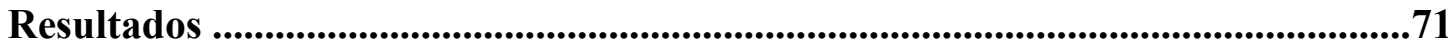

Determinação do índice de adesão e internalização de leveduras de Cryptococcus neoformans após estímulo com os polissacarídeos de Auricularia auricula e Ganoderma lucidum

Avaliação da capacidade microbicida sobre Cryptococcus neoformans de células dendríticas e macrófagos M1 e M2 estimuladas previamente com os polissacarídeos de Auricularia auricula e Ganoderma lucidum

Avaliação da produção de óxido nítrico e da secreção citocinas TNF- $\alpha$ e IL- $1 \beta$ e após estímulos com os polissacarídeos de Auricularia auricula e Ganoderma lucidum antes e durante a infecção por Cryptococcus neoformans

Avaliação da produção de espécies reativas de oxigênio em macrófagos M2 estimulados com polissacarídeos de cogumelos antes e após a infecção por Cryptococcus neoformans 78

Determinação da expressão de genes de macrófagos M2 relacionada á defesa do hospedeiro na infecção por Cryptococcus neoformans 79 Avaliação de curva de sobrevivência durante infecção com Cryptococcus neoformans sob estímulo com os polissacarídeos de Auricularia auricula e Ganoderma lucidum

CONCLUSÃO .91

Modelo proposto .092

PERSPECTIVAS. .93

REFERÊNCIAS .94

ANEXOS .121

PUBLICAÇÕES DO ALUNO 


\section{LISTA DE ABREVIATURAS}

AIDS - Síndrome da imunodeficiência adquirida

Ara - arabinose

A. auricula - Auricularia auricula

BMDC - bone marrow derived dendritic cells

BMDM - bone marrow derived macrophages

$\beta(\mathbf{1} \rightarrow \mathbf{3})$ - gluacanas beta-1,3

Calcitrol - $\alpha, 25$-dihidroxivitamina D3

CD - Cluster of differentiation

CLRs - C-type lectin receptors

Células NK - células Natural Killer

CG-EM - cromatografia em fase gasosa acoplada a espectrometria de massas

CNPq - Conselho Nacional de Desenvolvimento Científico e Tecnológico

$\mathbf{C O}_{2}$ - dióxido de carbono

C. gattii - Cryptococcus gattii

cm - centímetros

C. neoformans - Cryptococcus neoformans

CR3 - Receptor do Complemento 3

C-CSF - Fator estimulador de colônia de macrófagos

DC - células dendríticas

ELISA - Enzyme-Linked Immunosorbent Assay

EMBRAPA - Empresa Brasileira de Pesquisa Agropecuária

EPS - exopolissacarídeos

Fuc - Fucose

FcR $\gamma$ - Receptor FC gama

Gal - Galactose

GalXM - galactoxilomananas

Glc - Glicose

GM-CSF - Fator estimulador de colônias de granulócitos e de macrófagos

GXM - Glucuronoxilomanana

G. lucidum - Ganoderma lucidum

HDL3 - lipoproteína de alta densidade 3

$\mathbf{g} / \mathbf{L}$ - gramas por litro

iNOS - óxido nítrico sintase

IFN- $\boldsymbol{\gamma}$ - interferon gama

IL-1 - interleucina 1

IL-4 - interleucina 4

IL-6 - interleucina seis

IL-8 - interleucina 8

IL-10 - interleucina 10

IL-12 - interleucina 12

IL-12p70 - interleucina 12 subunidade p70

IL-13 - interleucina 13 
IL-1 $\alpha$ - interleucina 1 alfa

IL-1 $\boldsymbol{\beta}$ - interleucina 1 beta

kg - kilograma

LAL - lisado de Limulus amebocyte

LacCer - Lactosilceramida

LDH - lactato desidrogenase

LPS - lipopolisacarídeos

Man - Manose

MCL - macrophage C-type lectin

MIP2 - proteína inflamatória de macrófagos 2

mg - miligramas

$\mathbf{m g} / \mathbf{d L}$ - miligramas por decilitro

$\mathbf{m g} / \mathbf{m L}$ - miligramas por mililítro

$\mathbf{m L}-$ mililitros

MHC II - complexo principal de histocompatibilidade de classe II

Mincle - macrophage inducible C-type lectin

M1 - macrófagos classicamente ativados

M2 - macrófagos alternativos

NF-kB - factor nuclear kappa B

NHANES - National Heatlh and Nutrition Examination Survey

$\mathbf{n g} / \mathbf{m L}$ - nanogramas por mililitro

nm - nanômetros

NO - óxido nítrico

PAMPs - padrões moleculares associados a patógenos

PBS - Phospahte Buffered Saline

PI - Iodeto de propídeo

PTP - proteína tirosina fosfatase

PTX3 - pentraxina 3

PTGS2 - prostaglandina E2

rFC - fator recombinante $\mathrm{C}$

Raf-1 - serine/threonine-protein kinase

Rha - Raminose

Rib - Ribose

RMN - ressonância magnética nuclear

RPM - rotações por minuto

RPMI - Roswell Park Memorial Institute

Syk - Spleen tyrosine kinase

SP1 - receptor lisosfingolipideo

SRC - família de quinases

ROS - espécies reativas de oxigênio

TLRs - toll like receptors

TNF- $\boldsymbol{\alpha}$ - fator de necrose tumoral alfa

UFG - Universidade Federal de Goiás

UFRJ - Universidade Federal do Rio de Janeiro 
Xyl - Xilose

${ }^{\circ} \mathbf{C}$ - graus Celsius

$\mathbf{x} \mathbf{g}$ - força gravitacional

$\boldsymbol{\mu} \mathbf{L}-$ microlitros

$\boldsymbol{\mu g} / \mathbf{m L}$ - micrograma por mililítro

$\boldsymbol{\mu M}$ - micromolar 
ANEXO 9.1 AUTORIZAÇÃO DE ACESSO AO BANCO DE GERMOPLASMA

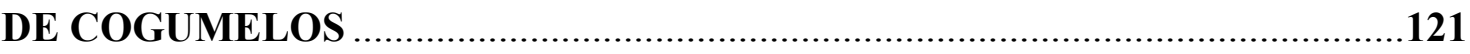

ANEXO 9.2 ANÁLISES ADICIONAIS DAS FRAÇÕES DE $A$. auricula ....................122

ANEXO 9.3. ESPECTRO 1D- ${ }^{1}$ H DE RMN DA FRAÇÃO SOLÚVEL DE A. auricula 123 ANEXO 9.4 TABELA DE DESLOCAMENTOS QUÍMICOS DA FRAÇÃO SOLÚVEL DE $A$. auricula 123

ANEXO 9.5 HISTOGRAMA DO ENSAIO DE AVALIAÇÃO DE EXPRESSÃO DAS MOLÉCULAS CO-ESTIMULATÓRIAS CD80, CD86 E MHC II 124

ANEXO 9.6 ESTRATÉGIA DE SELEÇÃO DA FENOTIPAGEM DE CÉLULAS DENDRÍTICAS 125

ANEXO 9.7 HISTOGRAMA DA ANÁLISE DA PRODUÇÃO DE ESPÉCIES REATIVAS DE OXIGÊNIO. 126

ANEXO 9.8 8 ESTRATÉGIA DE SELEÇÃO PARA AVALIAÇÃO DA PRODUÇÃO DE ESPÉCIES REATIVAS DE OXIGÊNIO EM MACRÓFAGOS M2. 128 


\section{LISTA DE FIGURAS}

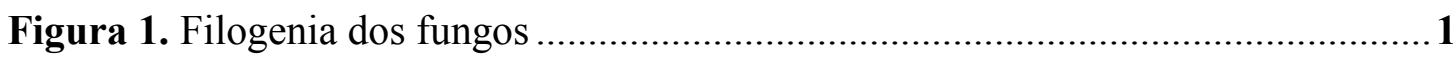

Figura 2. Aspecto estrutural macro e microscópico dos fungos..................................2

Figura 3. Cogumelo Auriculria auricula ................................................................ 5

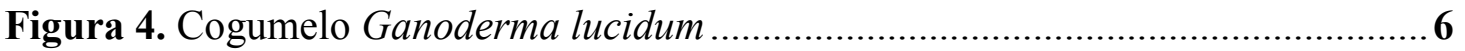

Figura 5. Estrutura molecular de $\beta$-glucanas do tipo $(1 \rightarrow 3),(1 \rightarrow 6)$ oriunda de leveduras

8

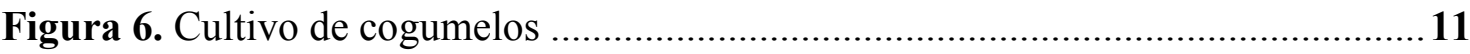

Figura 7. Esquema ilustrativo demonstrando o crescimento micelial a partir de hifas no

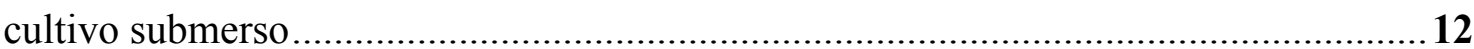

Figura 8. Esquema ilustrativo da ativação do sistema imunológico pelo estímulo de

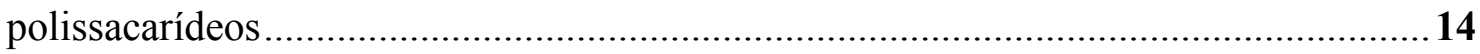

Figura 9. Esquema ilustrativo da formação da sinapse fagocítica.................................15

Figura 10. Primeiros desenhos de Crytococcus......................................................... 17

Figura 11. Ciclo de infecção de Cryptococcus envolvendo o ambiente e hospedeiro ..22

Figura 12. Avaliação dos constituintes monossacarídicos das frações solúveis e insolúveis de Auricularia auricula.....

Figura 13. Avaliação dos constituintes monossacarídicos das frações solúveis e insolúveis de Ganoderma lucidum

Figura 14. Espectro de RMN 2D- ${ }^{1} \mathrm{H}_{-}{ }^{13} \mathrm{C}$ HSQC da fração solúvel de A. auricula .......34

Figura 15. Espectro de RMN 2D- ${ }^{1} \mathrm{H}^{-13} \mathrm{C}$ HSQC da fração insolúvel de A. auricula ... 35

Figura 16. Viabilidade celular após estímulos com polissacarídeos de A. aurícula e $G$. lucidum 45

Figura 17. Viabilidade celular após estímulos com polissacarídeos de A. aurícula e $G$. lucidum avaliado por citometria de fluxo 46

Figura 18. Produção de citocinas após estímulos com polissacarídeos de A. auricula e $G$. lucidum 47

Figura 19. Células dendríticas estimuladas com compostos polissacarídeos tratados e não tratados de A. auricula e G. lucidum

Figura 20. Ensaio de polimixina $B$ para detecção de LPS nos compostos de polissacarídeos de A. auricula e G. lucidum 49

Figura 21. Estímulo de polissacarídeos de A. auricula e G. lucidum em células nocautes para TLR4 
Figura 22. Produção de TNF- $\alpha$ no bloqueio da fagocitose em células estimuladas com polissacarídeos de A. auricula e G. lucidum

Figura 23. Estímulo de polissacarídeos de A. auricula e G. lucidum em células nocautes para dectina-1 e TLR2

Figura 24. Ensaio repórter da interação de receptores CLRs e os polissacarídeos de $A$. auricula e G. lucidum.

Figura 25. Estímulo de polissacarídeos de A. auricula e G. lucidum em células nocautes para dectina-2.

Figura 26 Estímulo de polissacarídeos de A. auricula e G. lucidum em células nocautes para dectina-3.

Figura 27. Avaliação da participação de Syk e Raf-1 na sinalização de Auricularia auricula e Ganoderma lucidum.

Figura 28. Fenotipagem do estimulo de polissacarídeos de A. auricula e G. lucidum para células dendríticas positivas para as moléculas co-estimulatórias CD80, CD86 e MHC II

Figura 29. Extração de RNA de macrófagos M2 estimulados com polissacarídeos e infectados com C. neoformans. 68

Figura 30. Índice de adesão e internalização de leveduras de $C$. neoformans após estímulo de polissacarídeos de A. auricula e G. lucidum.

Figura 31. Ensaio de unidades formadoras de colônia de $C$. neoformans após estímulo de polissacarídeos de A. auricula e G. lucidum.

Figura 32. Porcentagem de atividade microbicida a $C$. neoformans após estímulo de polissacarídeos de A. aurícula e G. lucidum

Figura 33. Produção de TNF- $\alpha$ antes e durante a infecção de $C$. neoformans após estímulo de polissacarídeos de $A$. auricula e G. lucidum. 75

Figura 34. Produção de IL-1 $\beta$ antes e durante infecção de $C$. neoformans após estímulo de polissacarídeos de A. auricula e G. lucidum. 76

Figura 35. Produção de $\mathrm{NO}_{3}^{-}$antes e durante infecção de $C$. neoformans após estímulo de polissacarídeos de A. auricula e G. lucidum. 77

Figura 36. Produção de espécies reativas de oxigênio (EROs) por células M2 antes e durante infecção de $C$. neoformans após estímulo de polissacarídeos de $A$. auricula e $G$. lucidum

Figura 37. Avaliação da expressão gênica de macrófagos M1 estimulados e infectados com C. neoformans

Figura 38. Comparação de expressão dos transcritos de genes relacionados à resposta imune de células M2 estimuladas com $A$. auricula e $G$. lucidum e infectadas com $C$. neoformans 80

Figura 39. Comparação de expressão dos transcritos de genes relacionados à resposta imune de células M2 estimuladas com $A$. auricula e $G$. lucidum e infectadas com $C$. neoformans

Figura 40. Efeito dos polissacarídeos de Auricularia auricula e Ganoderma lucidum administrados via intranasal no curso da doença de $C$. neoformans in vivo 82 
Figura 41. Efeito dos polissacarídeos de Auricularia auricula e Ganoderma lucidum administrados via oral no curso da doença de $C$. neoformans in vivo...........................83

Figura 42. Modelo esquemático da sinalização de beta glucanas das frações dos cogumelos A. auricula (A) e G. lucidum (B) em células da imunidade inata 


\section{LISTA DE TABELAS}

Tabela 1. Diferentes fontes, estruturas e funções de beta-glucanas ..... 8

Tabela 2. Polissacarídeos isolados de diferentes fontes de G. lucidum ......................12

Tabela 3. Monossacarídeos padrão e os tempos de retenção utilizando a coluna HP5 30

Tabela 4. Composição monossacarídica das frações de G. lucidum e A. auricula.......31

Tabela 5. Análise estrutural das frações de A. auricula e G. lucidum ..........................35

Tabela 6. Oligonucleotídeos utilizados para a RT-PCR ............................................69

Tabela 7. Condições de ciclagem utilizadas para a RT-PCR...................................70 


\section{RESUMO}

Os fungos patogênicos oportunistas são responsáveis pela maior parte das infecções fúngicas nos seres humanos. Nos últimos anos, foi observado um aumento considerável na incidência de infecções causadas por esses organismos, principalmente em pacientes imunossuprimidos (portadores de HIV), transplantados ou em tratamento quimioterápico. Atualmente, a medicina está proporcionando um aumento na sobrevida desses pacientes, contudo a taxa de mortalidade continua elevada. A resposta imunitária é essencial para a proteção do hospedeiro durante o curso destas infecções e a ativação imunológica adequada é fundamental para controlar o patógeno. Neste contexto, a utilização de estimuladores de ativação é uma estratégia terapêutica interessante, uma vez que possibilita o controle eficiente destes fungos. Os polissacarídeos são importantes indutores da resposta imune e podem se ligar aos receptores de reconhecimento padrão. Além disso estas moléculas podem ativar a mecanismos da resposta imunológica, como estimular a produção de citocinas pró-inflamatórias e da explosão respiratória, aumentando assim a eficiência da atividade microbicida. Os polissacarídeos são constituintes da parede celular de fungos, leveduras, bactérias e plantas. Os cogumelos são fontes importantes de polissacarídeos que apresentam diversas propriedades biologicamente ativas, principalmente aquele relacionado a atividade imunomodulatória, sendo capazes de modular a ativação da imunidade inata e adaptativa. Assim, estes carboidratos podem ser diferenciados de acordo com as diversas características estruturais. Neste contexto, o objetivo deste trabalho foi selecionar e caracterizar os polissacarídeos provenientes dos cogumelos Ganoderma lucidum e Auricularia auricula, e avaliar sua capacidade imunomodulatória e a resposta imunitária do hospedeiro infectado pelo fungo patogênico Cryptococcus neoformans. Os resultados indicaram que ambas as frações (solúvel e insolúvel) de polissacarídicas extraídas dos cogumelos avaliados demonstraram uma composição monossacarídica similar (majoritariamente glicose na fração insolúvel e galactose na fração solúvel) e da identificação de beta glucanas nas frações solúveis e insolúveis de Auricularia auricula. Adicionalmente, a avaliação das frações dos cogumelos analisados não apresentou citotoxicidade, frações LPS free, uma atividade imunomodulatória em células dendríticas e macrófagos M1 e M2 por análise pela ligação aos receptores Dectina-1, TLR2 e TLR4). Ainda foi observado a secreção de citocinas (TNF- $\alpha$, IL-1 $\beta$, IL-10), de óxido nítrico e de espécies reativas de oxigênio. Assim como a modulação da imunidade adaptativa (pelo aumento da expressão de CD80, CD86 e MHCII) utilizando técnicas como ELISA e citometria de fluxo. Todavia, os ensaios in vitro referente à atividade microbicida das frações na infecção fúngica e também assim as análises de genes relacionados à defesa contra o patógeno assim como a avaliação da sobrevida in vivo indicaram que somente polissacarídeos da fração insolúvel de Auricularia auricula demonstraram serem promissores como adjuvantes para potencializar a defesa da imunidade inata referente à infecção por Cryptococcus neoformans.

Palavras chave: Auricularia auricula, Ganoderma lucidum, beta-glucana, imunidade inata, Cryptococcus neoformans. 


\begin{abstract}
Opportunistic pathogenic fungi are responsible for the majorist of human infection. In the last years, it was observed an increase in the incidence of infections by these organism, mainly in patients exhibiting immunosuppressed patients (HIV), transplanted or in chemotherapy treatment. Currently, medicine advances are providing to provide an increase in the survival of these patients although the mortality rate is still high. The immune response is essential to protect the host during these infections and the immune adequate activation is critical to pathogen control. In this context, immune cell activation stimulators is a therapeutic strategy promising, since it allows fungi efficient control. The polysaccharides are important immune response inductors and may receptors bind of pattern recognition receptors. Moreover, these molecules can activate various functions pro-inflammatory cytokine production stimulate and respiratory burst, thereby improving microbicide efficient activity. The polysaccharide are constituents of fungi bacteria and plants cell wall. The mushrooms are important sources of polysaccharides showing several active biological properties, mainly innate and adaptive immunomodulatory activity. These carbohydrates can be differentiated according to structural diversity. Then, the objective of this study was to select and to characterize polysaccharides from Ganoderma lucidum and Auricularia auricula mushrooms as well as to evaluate the host immune response infected by fungus pathogen Cryptococcus neoformans. The results showed that both fractions (soluble and insoluble) of polysaccharides obtained from Ganoderma lucidum and Auricularia auricula have similar monosaccharide composition (mainly glucose in insoluble fraction and galactose in soluble fraction) and beta-glucan in Auricularia auricula fractions. In addition, the assessment of insoluble fractions of the species analyzed showed acceptable cytotoxicity; free LPS molecules; immunomodulatory activity in dectin-1, TLR2 and TLR4 and macrophages by receptors ligation. Moreover, it was observed a production of TNF- $\alpha$, IL-1 $\beta$, IL-10 cytokine as well as nitric oxide and species oxygen reactive production. In addition; an adaptive immune modulation with increase of CD80, CD86 and MHCII. Nevertheless, in vitro and in vivo fungal infection assays presented that only fraction insoluble obtained from Auricularia auricula were promising adjuvants in innate immunity defense Cryptococcus neoformans infection.
\end{abstract}

Keywords: Auricularia auricula, Ganoderma lucidum, beta-glucan, innate immunity, Cryptococcus neoformans. 


\section{INTRODUÇÃO}

\section{Basidiomicetos}

Alguns estudos indicam que o número de espécies fúngicas no planeta esteja entre 500 mil a 1.5 milhões, tornando-os extremamente abundantes e diversos. Entretanto, foram descritas apenas 100 mil espécies (Kirk et al., 2008; Wasser, 2010; Wasser, 2014).

O reino Fungi é formado principalmente por bolores, leveduras e cogumelos e sua a classificação é baseada em características morfológicas (macroscópico, microscópico e ultramicroscópico), fisiológicas e moleculares. A filogenia fúngica define vários grupos fúngicos distintos como: quitridiomicetos (Allomyces, Batrachochytrium), zigomicetos (Rhizopus, Encephalitozoo), glomeromicetos (micorrizas arbusculares), ascomicetos (como Saccharomyces, Candida, Neurospora) e basidiomicetos (como Agaricus, Amanita) (Figura 1) (Madigan, 2010).

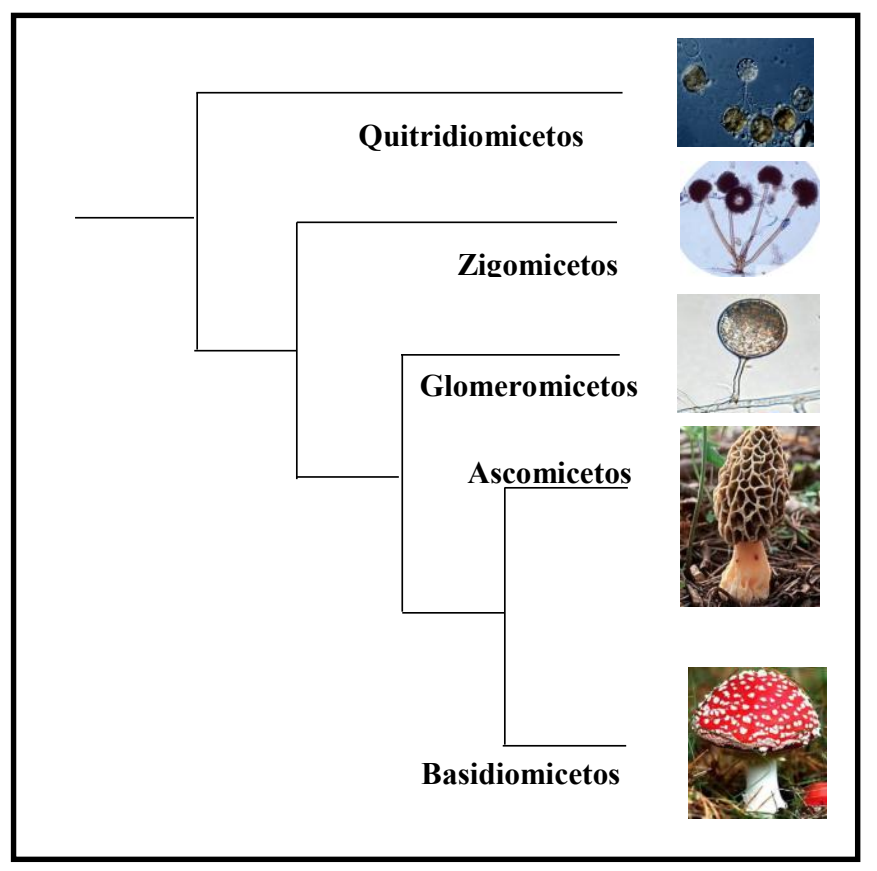

Figura 1. Filogenia dos fungos. Árvore geral filogenética, que retrata as relações entre os principais grupos ou filos de acordo com a sequências do gene de rRNA 18S) (Figura modificada de Madigan, 2010). 
Os fungos, geralmente são em sua maioria aeróbios e quimiorganotróficos, apresentando exigências nutricionais simples, alimentando-se com o auxílio da secreção de enzimas extracelulares, que digerem compostos orgânicos complexos (como proteínas e polissacarídeos) e seus constituintes monoméricos (aminoácidos e monossacarídeos). O habitat destes organismos é variado e a grande maioria vive em ambientes aquáticos (principalmente de água doce) e terrestres (solo e matéria vegetal morta), além de crescerem em temperaturas elevadas (aproximando-se até $62^{\circ} \mathrm{C}$ ) e $\mathrm{pH}$ ácido (Madigan, 2010).

A maioria dos fungos é multicelular sendo formado por uma rede de filamentos denominado de hifas, que podem apresentar diversas formas, tais como simples ou ramificadas, septada ou não-septada e que constituem o micélio dos fungos (Figura 2A) (Madigan, 2010). Os micélios se formam conforme o desenvolvimento das hifas individuais à medida que crescem na superfície e no interior do substrato constituído principalmente por compostos orgânicos e utilizando como uma fonte de nutrição. Após as ramificações das hifas se entrelaçarem, uma massa compacta se forma e quando as hifas ramificadas atingirem a superfície do substrato há a formação das ramificações aéreas. No caso dos cogumelos, a estrutura gerada denomina-se de basidiocarpo, constituída de duas partes: a estirpe (talo ou haste) e o píleo (chapéu). Além disso, mediante a essas ramificações aéreas são formados os esporos, denominados de conídios (Figura 2B), que são estruturas assexuais, pigmentadas e resistentes ao dessecamento. $\mathrm{O}$ conídio atua na dispersão do fungo para outros habitats. Uma vez formado o conídio, a coloração branca pode alterar-se para uma cor característica, que pode variar consideravelmente em preto, azul, esverdeado, marrom, amarelo ou vermelho (Madigan, 2010).

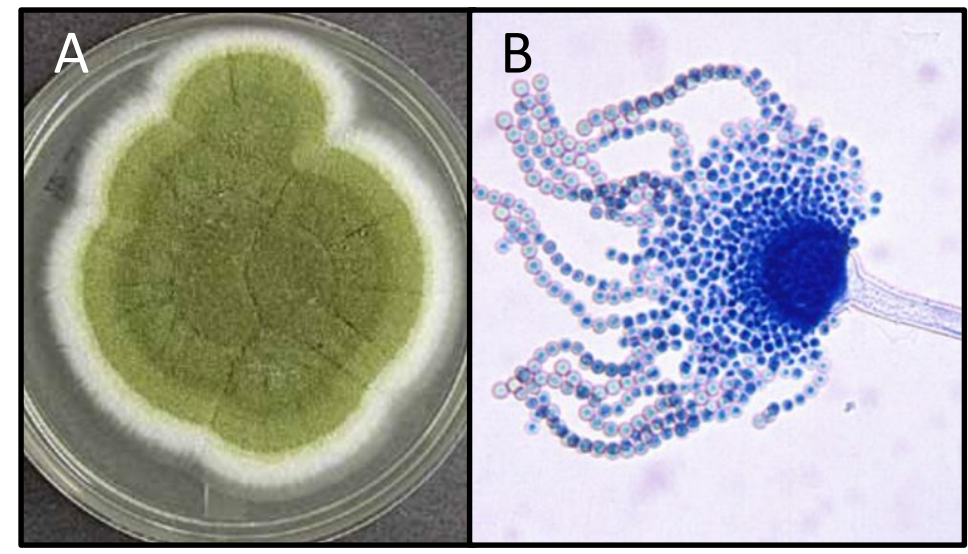

Figura 2. Aspecto estrutural macro e microscópico dos fungos. (A) colônias de uma espécie de Aspergillus, um ascomiceto. A aparência das massas de células filamentosas (o micélio) e dos esporos assexuais conferem às colônias um aspecto pulverulento e emanharado. (B) Conidiáforo e conídios de Aspergillus fumigatus. $\mathrm{O}$ comprimento de um conidióforo é de aproximadamente $300 \mu \mathrm{m}$ e dos conídios de aproximadamente $3 \mu \mathrm{m}$. Fonte: Madigan, 2010. Com modificações. 
A classificação filogênica dos basidiomicetos inclui mais de 25 mil espécies descritas e constituem um grande grupo de fungos. Neste caso, apresentam uma estrutura unicelular na qual os basidiósporos (esporos sexuais produzidos nas extremidades de uma estrutura claviforme) que são formados por meio da meiose (Carlile, et al., 2001; Lemos, 2009; Madigan, 2010; Silva, 2013). Os cogumelos são considerados como um grupo especial de fungos devido ao seu tamanho macroscópico ("macromiceto" ou macrofungo), um distinto corpo de frutificação e a produção de esporos.

Estimativas indicam que dentre as 100 mil espécies de fungos descritos, 14 mil sejam cogumelos (Kirk et al., 2008; Wasser, 2010). Neste âmbito, as espécies de cogumelos catalogadas encontram-se agrupadas como: comestíveis (aproximadamente 2 mil espécies descritas e 12 destas são fonte de alimento), venenosas (30 espécies) e medicinais. Ademais, novas espécies foram descobertas principalmente na Europa e América do Norte (Hawksworth, 2001; Mueller e Schmit, 2007, Wasser, 2010).

\section{Cogumelos comestíveis}

Os cogumelos são utilizados como fonte comestível e medicinal há mais de 2.000 anos, especialmente nos países asiáticos. Ao longo da história, o papel deste macrofungo foi documentado pelas civilizações grega, romana, egípcia, chinesa, mexicana e indiana (Rowan et al., 2003; Cui et al, 2007; revisado de Smiderle, 2008; Wasser, 2011; Feeney et al., 2014).

Os primeiros indícios do cultivo de cogumelos medicinais são relatados na Mesoamérica (México, Guatemala, El Salvador, Belize, Honduras, Nicarágua e Costa Rica), África, Argélia, Egito e a Sibéria (Wasser, 2010). Porém, a primeira estrutura voltada para o cultivo e produção comercial de cogumelos ocorreu somente em 1894, em Chester Count na Pensilvânia (Estados Unidos) (Beyer, 2008; revisado de Silva 2011).

Atualmente os maiores produtores de cogumelos são China, Estados Unidos, Itália, Holanda, Polônia e Japão, cultivando quinze tipos distintos de cogumelos sendo responsáveis por 90\% da produção global (Feeney et al., 2014, revisado de Viana, 2014). Em 2014, a produção mundial foi de 743,2 mil toneladas, o que movimentou $€ 1,7$ bilhões 
de euros e para 2015 estimava-se uma produção de 1.16 milhão de toneladas (Boon, 2015). As espécies de cogumelos mais comercializadas mundialmente são Agaricus bisporus (Champignon de Paris), Pleurotus ostreatus (Shimeji) e Lentinula edodes (Shiitake) (revisado de Gonçalves, 2012; revisado de Silva, 2015).

O cultivo de cogumelos comestíveis no Brasil iniciou-se entre 1950 e 1980, introduzido por chineses em Mogi das Cruzes, São Paulo (Bett e Perondi, 2011, Zied et al., 2014). Atualmente, devido ao seu modo de produção, há um aumento no número de pequenos e médios produtores. O cogumelo mais cultivado no Brasil é o Agaricus bisporus (representando 55\% da produção nacional), seguidos por Pleurotus spp., Lentinula edodes e Agaricus subrufescens ou Agaricus blazei (Zied, et al, 2014).

A produção mundial de cogumelos aumentou dez vezes entre 1969 e 2009 (Zhang, 2014). Dentre os fatores responsáveis pela crescente produção mundial e consumo per capta de cogumelos, estão as propriedades nutricionais e as medicinais (revisado de Silva, 2015). Neste caso, os fatores nutricionais que mais se destacam são a quantidade significativa de proteínas (com aminoácidos essenciais), carboidratos, minerais (como ferro, potássio e fósforo), vitaminas do complexo B (riboflavina, tiamina, niacina), vitamina $\mathrm{C}$ e provitamina $\mathrm{D}_{2}$, compostos fenólicos entre outros (Chang e Miles, 2004; Cui et al, 2007; Zied, et al, 2014). Ademais, apresenta em sua composição uma quantidade moderada de fibras e cinzas e baixa quantidade de lipídeos (Chang \& Miles, 2004).

Atualmente, foram relatadas na literatura 126 propriedades medicinais relacionadas aos cogumelos, dentre elas destacam-se as atividades antioxidante, anticancerígena e imunomodulatória (Lull et al., 2005; Chan et al., 2009; Ramberg et al., 2010; Lo e Wasser, 2011; Wasser, 2011).

\section{Auricularia auricula}

O primeiro cogumelo comestível a ser cultivado pelos seres humanos foi a espécie Auricularia auricula (A. auricula) (Figura 3), pelo sistema de toras de madeira, há mais de 1.000 anos na China (revisado de Herrera, 2001; revisado de Silva, 2011; Li et al., 
2014). Este macrofungo apresenta importantes características nutricionais e medicinais, dentre elas as atividades anticancerígena, antioxidante, imunomoduladora, de manutenção da homeostase, dentre outras (Ma et al., 2010, Du et al., 2013; Vijai et al., 2015). Ademais, apresenta uma distribuição climática preferencialmente nos trópicos, subtrópicos e regiões temperadas, sendo o quarto mais cultivado no mundo (Du et al., 2013; Li et al., 2014).

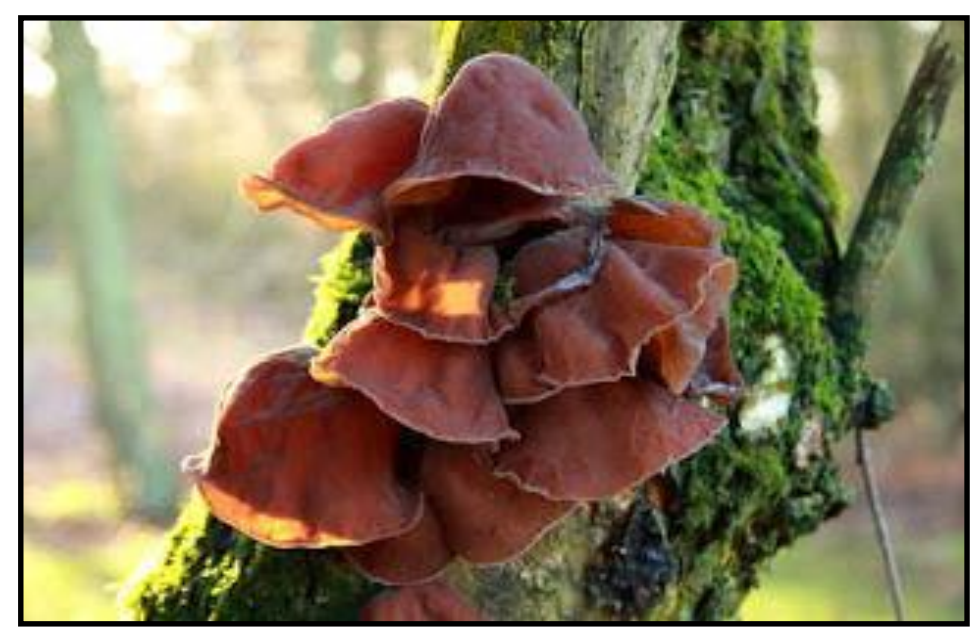

Figura 3. Cogumelo Auriculria auricula.

Fonte: http://sublimart.blogspot.com.br/2009_12_01_archive.html

Recentemente, foi descrita a atividade biológica protetora de A. auricula em camundongos expostos a doses letais de radiação (Revskaya et a., 2012). O trabalho demonstrou que a administração de carboidratos extraídos do corpo frutífero do cogumelo no local afetado por radiações influenciou no aumento de células linfoides e foi determinante na recuperação hematológica por meio da hematopoese extra medular. Ademais, relatos da literatura demonstraram que o estímulo de Auriculria aurícula influenciou no aumento da proliferação de células $\mathrm{B}$, na produção de óxido nítrico $\left(\mathrm{NO}^{-}\right)$ por macrófagos, bem como nos níveis elevados de fator de necrose tumoral alfa (TNF- $\alpha$ ) e interferon gama (IFN- $\gamma$ ) em ensaios in vitro utilizando-se células mononucleares do sangue periférico cultivadas in vitro (Rai et al., 2004; Zuo et al., 2008; Li et al., 2012).

\section{Ganoderma lucidum}


O cogumelo Ganoderma lucidum (G. lucidum) é a espécie mais estudada dentre todos os cogumelos. Os primeiros estudos científicos utilizando este cogumelo (Figura 4) foram realizados por pesquisadores japoneses, que desenvolveram métodos de produção eficientes e demonstraram que os basidiomas (estrutura microscópica produtora de esporos no corpo de frutificação) poderiam conter diversas cores. Essa variação de cores referia-se às condições ambientais de cultivo e representam diferentes concentrações de substâncias biologicamente ativas (Buchanan et al., 2001; revisado de Viana, 2014), como polissacarídeos e glicoproteínas.

O macrofungo G. lucidum é um dos cogumelos medicinais mais populares no Japão (conhecido como Reishi), China (conhecido como Lingzhi), Coréia e Estados Unidos (Baskar et al., 2011). Na história antiga da China, o fungo G. lucidum era reservado exclusivamente para os imperadores e membros privilegiados da sociedade devido à sua raridade e por ser considerado um "elixir da vida", por estar associado à longevidade, poder divino, símbolo do sucesso e bem-estar (Benzie e Wachtel-Galor, et al., 2011).

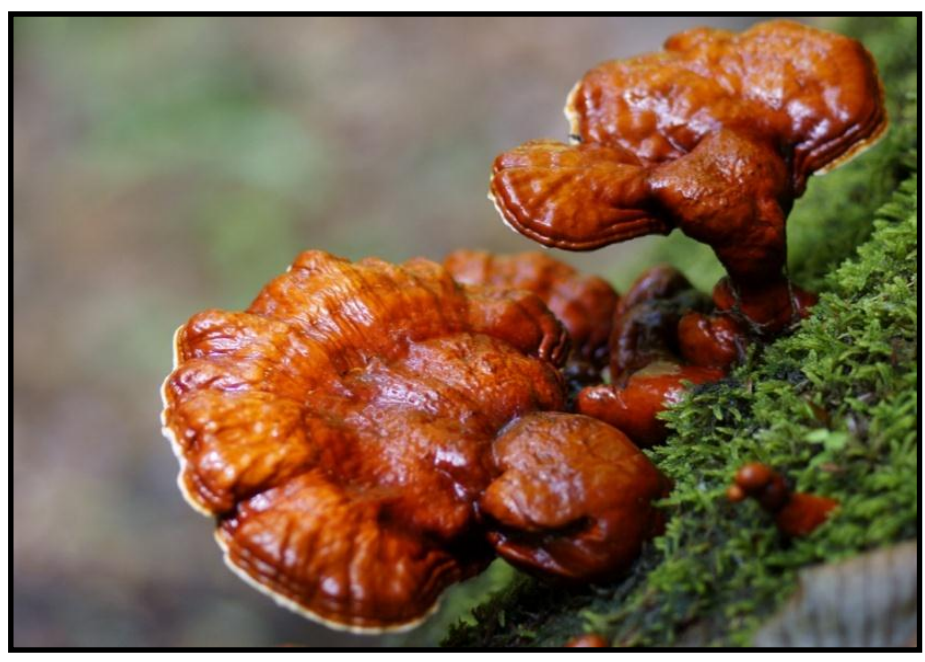

Figura 4. Cogumelo Ganoderma lucidum.

Fonte: https://mushroomsworld.wordpress.com/category/lingzhi-ganoderma-lucidum/

Os efeitos imunomodulatórios de G. lucidum promovem a ativação da imunidade humoral e celular, incluindo a ativação de células dendríticas, fagócitos, linfócitos B e T, além de células Natural Killer (células NK) (Berovic et al., 2003; Boh et al., 2007; Boh et al., 2013). Estudos anteriores relataram que em macrófagos, G. lucidum aumentou: (1) a fagocitose in vivo e in vitro, (2) a produção de interleucina 1 alfa (IL-1 $\alpha$ ) e (3) TNF- $\alpha$ (Li et al., 2000; Lin, 2001; Jiang et al., 2003). Tang et al. (2004) avaliaram a ativação de 
macrófagos de camundongos in vitro pelo estímulo de uma fração alcalina de G. lucidum, cujo resultado indicou a secreção da interleucina 1 beta (IL-1 $\beta$ ) e de $\mathrm{NO}^{-}$. Atualmente, mais de cinquenta espécies de cogumelos estão relacionadas à atividade imunomodulatória, cujos compostos obtidos são agrupados em quatro categorias, baseadas em suas características químicas como as lectinas, os terpenóides, as proteínas e os polissacarídeos (Enshasy e Hatti-Kaul, 2013).

\section{Polissacarídeos}

Os polissacarídeos são polímeros de carboidratos que variam entre baixa a alta massa molecular, sendo constituídos por monossacarídeos unidos por ligações glicosídicas. Esses polímeros diferenciam-se, principalmente, pela composição dos monômeros, tipo de ligação, comprimento da cadeia e número de ramificações (Freimund et al., 2003; revisado de Smiderle, 2008).

Essas macromoléculas são produzidas principalmente por bactérias, fungos e plantas (Fuentes et al., 2011), e são importantes na estrutura celular (celulose, glicoproteínas e quitina), no armazenamento de energia (glicogênio e amido), como indicadores de endereçamento para proteínas e ainda como mediadores para interações específicas entre as células e/ou a matriz extracelular (Lehninger, 2002; revisado de Smiderle, 2008). Desde 1936, têm sido estudadas as aplicações funcionais e imunológicas do polissacarídeo beta-glucanas têm sido estudadas (Morgan, 1936; Liu et al., 2008; Ferreira et al., 2015). As beta-1,3-glucanas ou $\beta(1 \rightarrow 3)$ são polímeros de glicose, em conformação anomérica $\beta$, cuja ligação entre as unidades glicosídicas ocorre nos carbonos um e três. Estruturalmente, apresentam uma cadeia principal de ligações do tipo beta $1 \rightarrow 3$ de D-glicose com ramificações de cadeia laterais com ligações beta do tipo $1 \rightarrow 6$ (Figura 5). Outras estruturas encontradas em beta-glucanas são principalmente com ligações do tipo 1,3 de D-glicose contendo ramificações de cadeia lateral com ligações beta do tipo $1 \rightarrow 2,1 \rightarrow 3$ e $1 \rightarrow 4$ (revisado de Smiderle, 2008; revisado de Souza, 2014; Zhang e Edgar, 2014). 


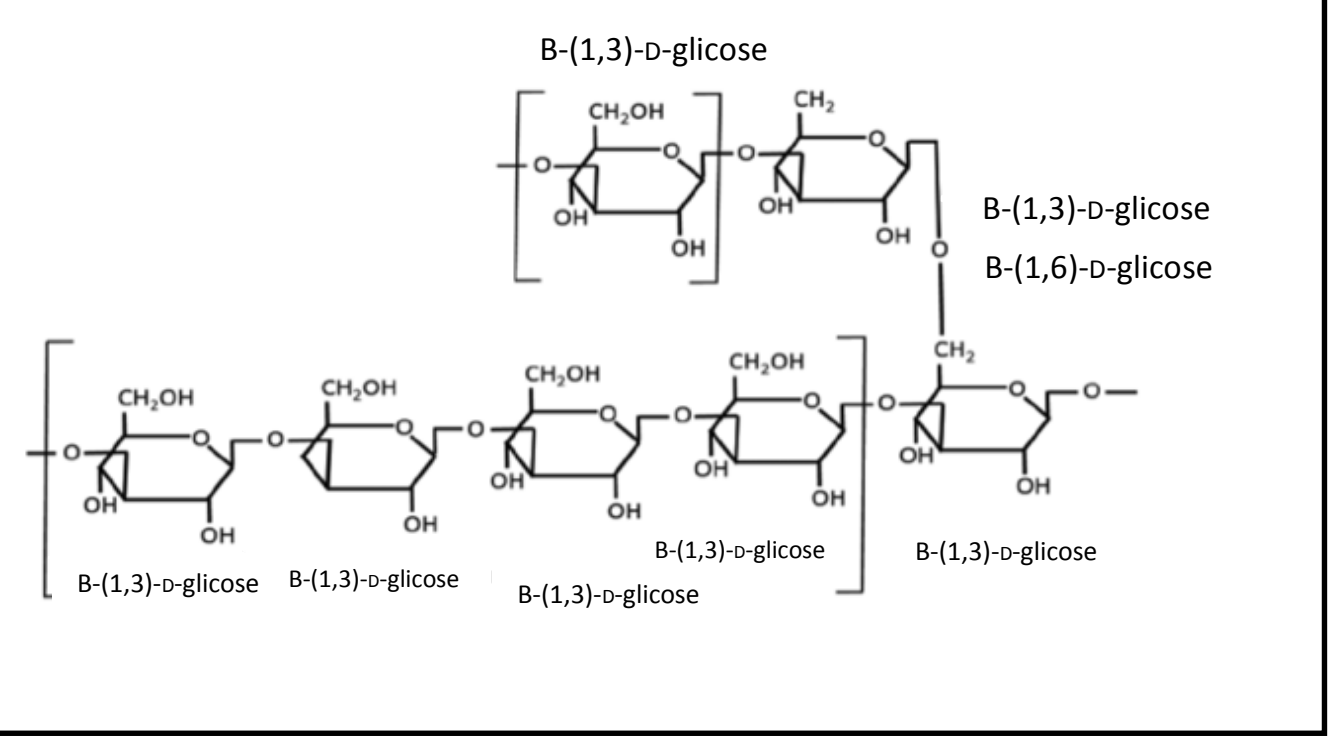

Figura 5. Estrutura molecular de $\beta$-glucanas do tipo $(1 \rightarrow 3),(1 \rightarrow 6)$ oriunda de leveduras. Fonte: Jacob e Pescatore, 2014). Com adaptações.

As beta-glucanas são produzidas por diversos organismos, como as algas, as bactérias, as plantas superiores e os fungos (Tabela 1), e cujas funções envolvem a formação da parede celular de plantas e fungos, reserva em algas e plantas (como a defesa contra herbívoros) (Bartnicki-Garcia 1968; Gorin e Spencer 1968; Wessels e Siestma 1982; Aspinall 1982; Krainer et al., 1994; Bacic et al. 1998, revisado de Souza, 2014).

Tabela 1. Diferentes fontes, estruturas e funções de beta-glucanas.

\begin{tabular}{lcccc}
\hline \multicolumn{1}{c}{ Fonte } & Beta-glucana & $\begin{array}{c}\text { Tipo de } \\
\text { ligação } \\
\text { principal }\end{array}$ & Função & Observação \\
\hline $\begin{array}{l}\text { Vegetais em } \\
\text { geral, } \\
\text { bactérias }\end{array}$ & $\begin{array}{c}\text { Celulose, } \\
\text { Lipopolisacarídeo }\end{array}$ & $\beta-1,4$ & $\begin{array}{c}\text { Principal } \\
\text { constituinte } \\
\text { da parede } \\
\text { celular }\end{array}$ & Linear; insolúvel \\
Algas pardas & Laminarina & $\beta-1,3$ & Reserva & $\begin{array}{c}\text { Linear - insolúvel; } \\
\text { pode possuir } \\
\text { ramificações } \beta-1,6 \\
\text { tornando a molécula } \\
\text { solúvel; gelificante }\end{array}$ \\
$\begin{array}{c}\text { Vegetais } \\
\text { superiores }\end{array}$ & Calose vegetal & $\beta-1,3$ & $\begin{array}{c}\text { Formação } \\
\text { de poros do } \\
\text { floema }\end{array}$ & Linear; insolúvel \\
& & & & \\
\hline
\end{tabular}




\begin{tabular}{|c|c|c|c|c|}
\hline Coníferas & Laricinana & $\beta-1,3$ & $\begin{array}{c}\text { Reserva; } \\
\text { constituinte } \\
\text { da parede } \\
\text { celular }\end{array}$ & $\begin{array}{c}\text { Solúvel; } \\
\text { Ramificações } \beta-1,6\end{array}$ \\
\hline Fungos & $\begin{array}{c}\text { Pachyman (Poria } \\
\text { cocos) }\end{array}$ & $\beta-1,3$ & $\begin{array}{c}\text { Constituinte } \\
\text { da parede } \\
\text { celular }\end{array}$ & Linear; insolúvel \\
\hline $\begin{array}{c}\text { Fungos e } \\
\text { macrofungos }\end{array}$ & $\beta$-glucana & $\beta-1,3$ e 1,6 & $\begin{array}{c}\text { Constituinte } \\
\text { da parede } \\
\text { celular }\end{array}$ & $\begin{array}{c}\text { Ramificações } \beta-1,6, \\
\text { solúvel e insolúvel, } \\
\text { gelificante }\end{array}$ \\
\hline Cereais & $\beta$-glucana & $\beta-1,4$ e $\beta-1,3$ & $\begin{array}{l}\text { Constituinte } \\
\text { da parede } \\
\text { celular; } \\
\text { reserva }\end{array}$ & $\begin{array}{l}\text { Linear; solúvel, alta } \\
\text { capacidade } \\
\text { gelificante }\end{array}$ \\
\hline Líquens & Liquenana & $\beta-1,4$ e $\beta-1,3$ & $\begin{array}{l}\text { Constituinte } \\
\text { da parede } \\
\text { celular; } \\
\text { reserva }\end{array}$ & $\begin{array}{l}\text { Linear; solúvel, alta } \\
\text { capacidade } \\
\text { gelificante }\end{array}$ \\
\hline
\end{tabular}

Fonte: Genta, 2004. Com adaptações

\section{Homo e heteropolissacarídeos de basidiomicetos}

Em 1957, Lucas et al. publicaram um dos primeiros trabalhos demonstrando o efeito significativo na inibição de células tumorais de sarcoma S-180, a partir de moléculas isoladas de Boletus edulis (revisado de Smiderle, 2008). A partir deste trabalho, inúmeras pesquisas foram publicadas mencionando a atividade biológica de moléculas extraídas de basidiomicetos (Zhang et al., 2007).

Os basidiomicetos são importantes fontes de beta-glucanas, que apresentam diversas propriedades biologicamente ativas, dentre elas destaca-se a atividade imunomodulatória (Ali, 2009; Vetvicka, 2011). Ademais, algumas beta-glucanas isoladas apresentam interesse clínico e encontram-se disponíveis comercialmente, tais como: (1) Lentinano ou Lentinan (isolado do cogumelo Lentinula edodes), (2) Schizophyllan (isolado do cogumelo Schizophyllum commune), (3) PSK (Krestin) (isolado do cogumelo 
Coriolus versicolus). (4) Scleroglucan (isolado de Sclerotium rolfsii) e (5) Grifolan (isolado de Grifola frondosa) (Zekovic et al., 2005; Ali, 2009; Carbonero et al., 2012).

As beta-glucanas do tipo $(1 \rightarrow 3 ; 1 \rightarrow 6)$ são reconhecidas como potentes polissacarídeos bioativos provenientes de fungos (Chen e Seviour, 2007; revisado de Wang et al., 2014), constituindo parte da parede celular de organismos. Estas moléculas e seus conjugados são comercializados para auxiliar tratamentos clínicos em pacientes com câncer, tais como Schizophyllan (Schizophyllum commune), Lentinan (Lentinula edodes), Grifolan (Grifola frondosa) e Krestin ou PSK (complexo proteínapolissacarídeo, Trametes versicolor). No Japão, o fármaco Lentinan é indicado para auxiliar pacientes com câncer gástrico, o que demonstrou um aumento na taxa de sobrevida dos pacientes (Wang et al., 2014).

Deste modo, diversos polissacarídeos foram isolados de basidiomicetos, como as glucanas, as heterogalactanas, bem como as heteromananas, e podem ser divididos em dois grupos: os homopolissacarídeos (constituídos por um tipo de monossacarídeo) e os heteropolissacarídeos (constituído por mais de um tipo de monossacarídeo) (Schepetkin e Quinn, 2006; revisado de Smiderle, 2008).

Devido ao interesse por polissacarídeos bioativos provenientes de homopolissacaríedos (caso da beta-glucana), existem poucos relatos referente aos heteropolissacarídeos. Entretanto, algumas moléculas já foram descritas, como as fucoxilomananas (extraídas de Ganoderma lucidum, Fomes annosus e Polyporus pinicola) e as fucogalactanas (Ganoderma applanatum e Fomes annosus) (revisado de Smiderle, 2008). Dentre esses polímeros, sejam homo ou heteroglucanas, que contenham ligações glicosídicas $\beta$-(1,3), $\beta$ - $(1,4)$ e $\beta$-(1,6), estes atuam com um papel chave na atividade biológica dos cogumelos (Manzi e Pizzoferrato, 2000). Entretanto, apesar da escassez de publicações a respeito da atividade biológica dos heteropolissacarídeos, há um interesse no estudo sobre estas moléculas, principalmente devido a algumas propriedades biológicas envolvendo os monômeros de glicose, manose e galactose (Zhang et al., 2007).

\section{Cultivo Submerso}


A capacidade de cultivar cogumelos em meio líquido é estudada há mais de 45 anos. A primeira tentativa ocorreu utilizando Agaricus campestres em meio aquoso contendo nutrientes e em agitação (Leonowicz, et al., 1991, revisado de Confortin, 2006).

Os cogumelos são produzidos geralmente em substratos sólidos (Figura 6a), utilizando madeira ou compostos lignocelulósicos (madeira, palha, vegetais). O tempo de cultivo varia entre 4 a 6 meses para obtenção do corpo frutífero ou de frutificação (Cui et al., 2006).

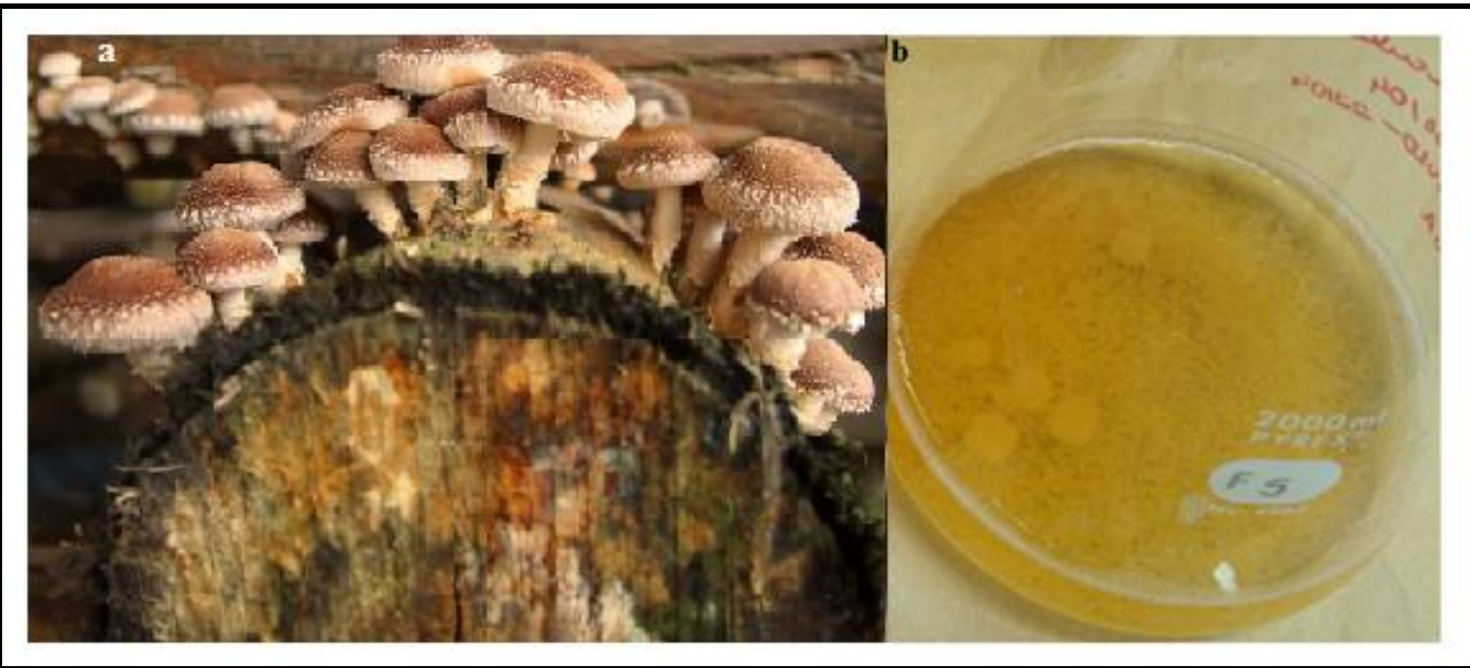

Figura 6. Cultivo de cogumelos. (a) Cultivo de cogumelos Shiitake em toras de madeira; (b) Cultivo submerso de cogumelos em meio líquido.

Fonte: (a) http://www.flfrevista.pt/events/aprender-a-produzir-cogumelos-shiitake-em-troncos-demadeira.

Contudo, uma alternativa é o crescimento em meio líquido de cultura específico, denominado de cultivo submerso ou fermentação submersa (figura 6b). Esta técnica é vantajosa devido ao crescimento mais rápido, a obtenção de massa fúngica de qualidade consistente, dentre outros (Tang e Zhong, 2002; Cui et al., 2006; Wang et al., 2014).

No cultivo líquido não ocorre o estágio de formação do corpo de frutificação, mas as hifas crescem em conjunto ao longo de uma superfície formando os micélios (Figura 7), que podem produzir os polissacarídeos exsudatos ou exopolissacarídeos (EPS). Além disso, a biomassa produzida pode ser diretamente usada como inóculo para novos processos produtivos, como fonte para a produção de metabólitos intermediários, como 
complemento de alimentos ou nutrientes enriquecidos e para extração de aromas e sabores (Maziero et al., 1999; Rosado et al., 2003; revisado de Confortin, 2006; Madigan, 2010).

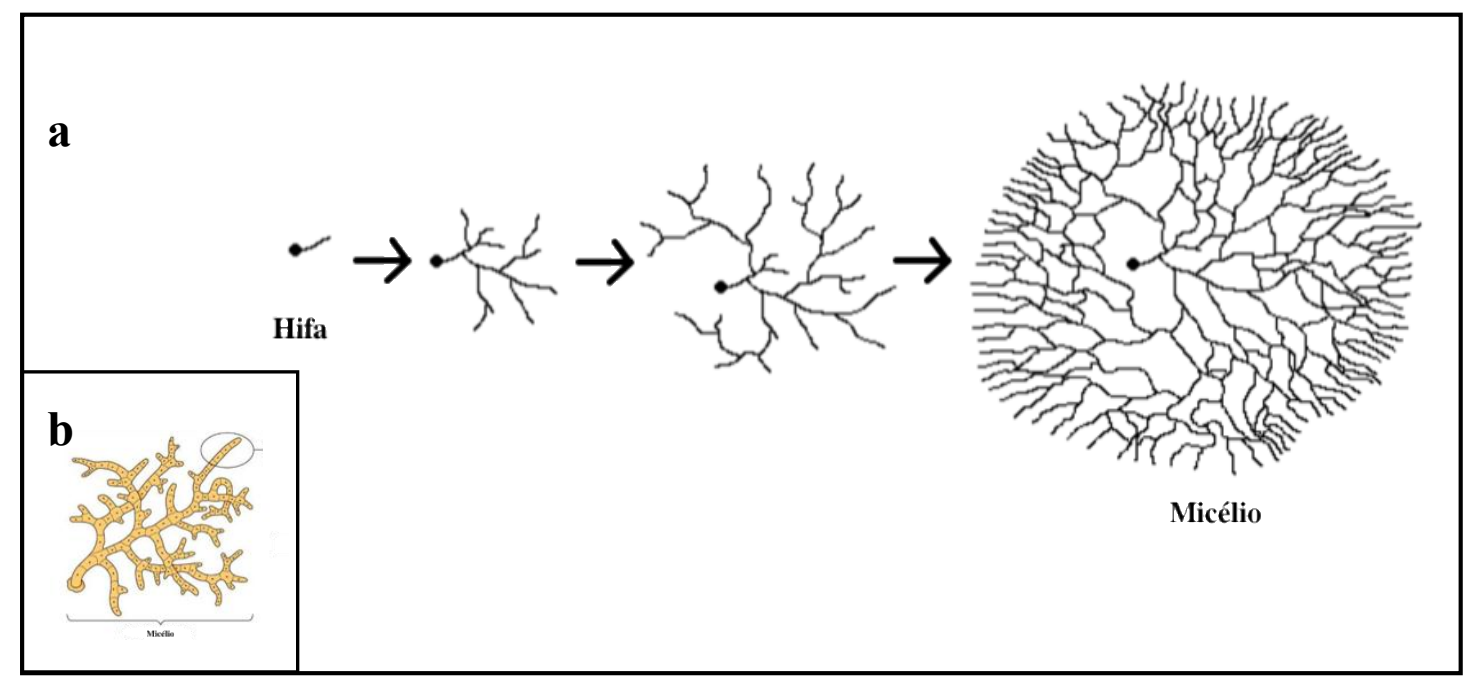

Figura 7. Esquema ilustrativo demonstrando o crescimento micelial a partir de hifas no cultivo submerso. (a) inicialmente o esporo (ponto preto) encontra-se junto ao tubo de germinação. Em seguida, as fases posteriores demonstram a expansão até a formação do micélio; (b) Estrutura miceliar. Fonte: (a) Herbário Nacional da Austrália, 2016; (b) Universidade de Rai, 2016. Com adaptações.

Deste modo, utilizando-se esse bioprocesso também ocorre a obtenção de endopolissacarídeos (provenientes de isolados do micélio), além de outras moléculas simultaneamente obtidas ao crescimento micelial (Kim, et al, 2001; Cui et al., 2006, revisado de Bortoli, 2015). A técnica referida é considerada eficiente para a obtenção de polissacarídeos de Ganoderma lucidum, cujos estudos obtiveram um rendimento de 200 a 1500 miligramas por decilitro (mg/dL) de polissacarídeos (Wang et al., 2014). A tabela 2 apresenta os polissacarídeos obtidos em métodos de cultivo distintos de Ganoderma lucidum.

Tabela 2. Polissacarídeos isolados de diferentes fontes de G. lucidum.

\begin{tabular}{cc}
\hline Fonte & Principais Compostos Obtidos \\
\hline Corpo Frutífero & $\beta-(1 \rightarrow 3)$-D-Glucana \\
Micélio & $\beta-(1 \rightarrow 3)$-D-Glucana com ramificações $\beta-(1 \rightarrow 6)$ \\
Meio de Cultura & Glicoproteínas
\end{tabular}

Fonte: Chang e Miles, 2004. Com adaptações 
A composição química dos cogumelos pode variar de acordo com a linhagem, as condições de cultivo e fatores ambientais. O cultivo dos basidiomicetos está sujeito a uma variedade de condições físico-químicas tais como a aeração, o pH, a densidade, a temperatura, a umidade e a composição do substrato de cultura. Recentemente, o cultivo submerso tornou-se uma técnica biotecnológica promissora para a obtenção de metabólitos com atividades biológicas importantes, devido à facilidade de reprodução das condições experimentais (Fang et al., 2002; Tang e Zhong, 2002).

As técnicas de cultivo submerso são amplamente desenvolvidas para a propagação de micélios da maioria dos cogumelos medicinais (Smith et al., 2002; revisado de Confortin, 2006), proporcionando taxas elevadas de exopolissacarídeos, dentre eles betaglucanas extracelulares que são um dos homopolissacarídeos mais comuns em basidiomicetos (Zhang et al., 2007). Ademais, a otimização do crescimento submerso é continuamente avaliada, cujos estudos podem utilizar processos baseados em análises estatísticas para otimizar a produção de metabólitos (Xu et al., 2002, Cui et al., 2006).

\section{Imunologia dos Polissacarídeos}

Os polissacarídeos com atividade imunoestimulatória podem interagir direta ou indiretamente com o sistema imunológico, ativando principalmente monócitos, células dendríticas, macrófagos e neutrófilos, bem como desencadear eventos celulares e moleculares (Schepetkin e Quinn, 2006; Minato et al., 2016) (Figura 8). 


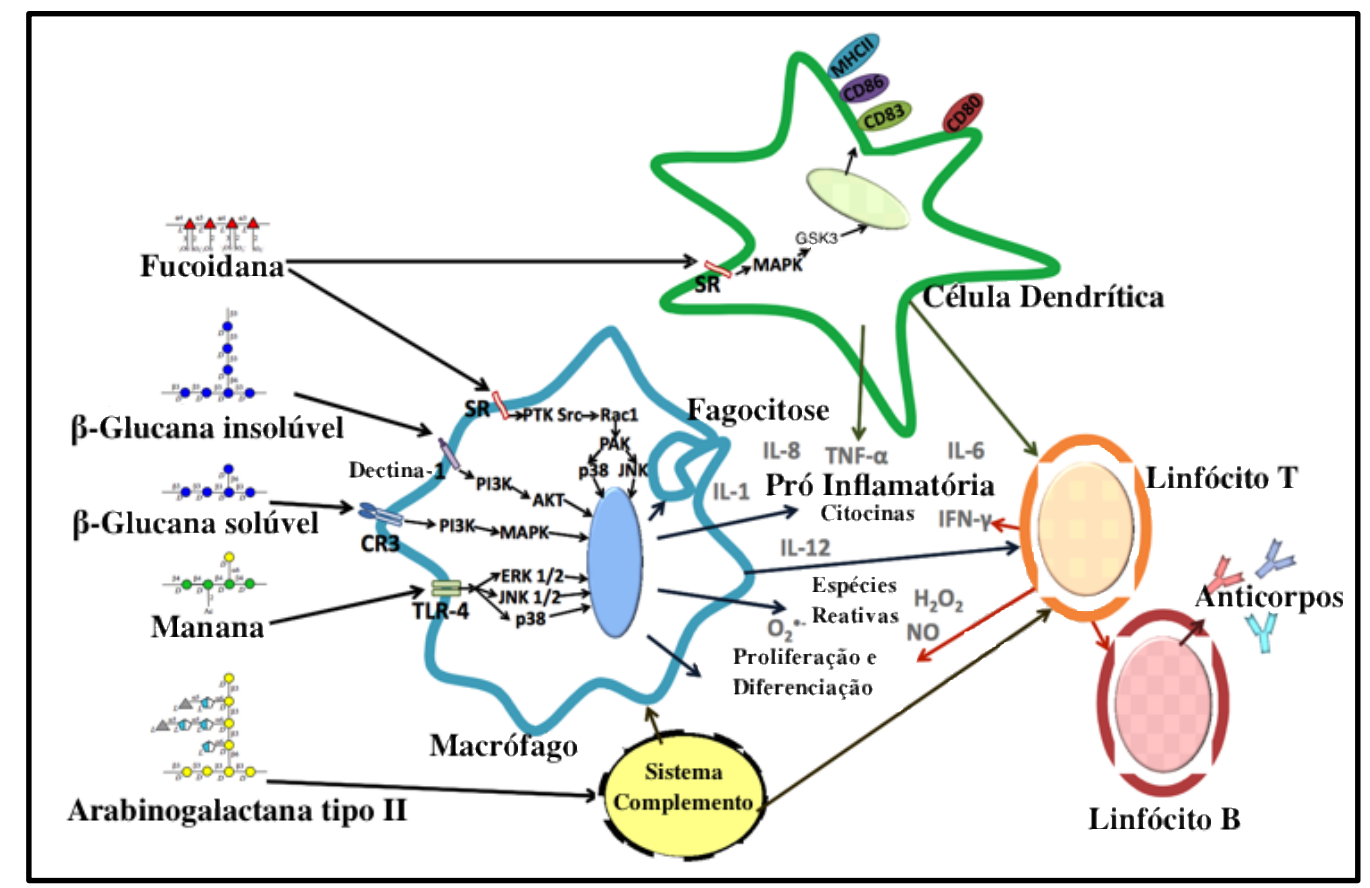

Figura 8. Esquema ilustrativo da ativação do sistema imunológico pelo estímulo de polissacarídeos. Akt, proteína quinase B; CD, cluster de diferenciação; CR3, receptor do complemento 3; ERK 1/2, sinal extracelular regulado pelas quinases $1 / 2$; GSK3, glicogênio sintase quinase $3-\beta ; \mathrm{H}_{2} \mathrm{O}_{2}$, peroxido de hidrogênio, IFN, interferon; IL, interleucina; JNK 1/2, Jun N-terminal 1/2 quinase; JNK, c-Jun N-terminal quinase; MAPK, p38 proteína quinase ativada por mitógeno; MHC II, complexo maior de histocompatibilidade classe II; NO, óxido nítrico, $\mathrm{O}_{2}$, ânion superóxido, $\mathrm{PAK}$, quinase ativada por p21; PI3K, quinase fosfatidilinositol-3; PTK, proteína tirosina quinase; Rac 1, substrato de toxina botulínica relacionada a C3; SR, receptor Scavenger; Src, proteína quinase proto-oncogene; TLR-4, receptor do tipo Toll 4; TNF- $\alpha$, fator de necrose tumoral alfa. Beta-glucanas solúvel e insolúvel também são reconhecidos por células dendríticas por meio de dectina-1. Fonte: Ferreira et al., 2015. Com adaptações.

Os carboidratos podem estimular a proliferação e/ou diferenciação de macrófagos (Ramesh, et al., 2002), a produção de espécies reativas de oxigênio (ROS), de óxido nítrico (Xie et al., 2008), a secreção de citocinas pró inflamatórias como TNF- $\alpha$, interleucina 1 (IL-1), interleucina 6 (IL-6), interleucina 8 (IL-8), interleucina 12 (IL-12), IFN- $\gamma$ (Ohta et al., 2007; Schepetkin, et al., 2005; Khil'chenko et al., 2011; Xu, 2012) e a ativação do sistema complemento (Samuelsen, et al., 2011) e do inflamassoma (Yang et al., 2015).

As células fagocíticas reconhecem os polissacarídeos, dentre eles as betaglucanas, utilizando receptores toll like receptors (TLRs) e C-type lectin receptors (CLRs) (Abbas et al., 2015), tais como TLR2 e dectina-1, respectivamente. Estudos 
envolvendo antagonistas e anticorpos monoclonais bloqueadores demonstraram que dectina-1 é o principal receptor que medeia as beta-glucanas e a atividade de leucócitos, principalmente macrófagos e células dendríticas (Brown et al., 2002; Gantner et al., 2003; Rogers et al., 2005; Willment et al., 2005). Goodridge et al. (2011) identificaram o mecanismo molecular (Figura 9) pelo qual dectina-1 interage com ligantes solúveis e insolúveis de beta-glucanas. O receptor liga-se ao polissacarídeo solúvel e insolúvel, contudo a sinalização intracelular foi observada somente quando o receptor se ligou a beta-glucanas insolúveis, devido a dependência de grupamentos de diferenciação (CD) 45 e CD148.

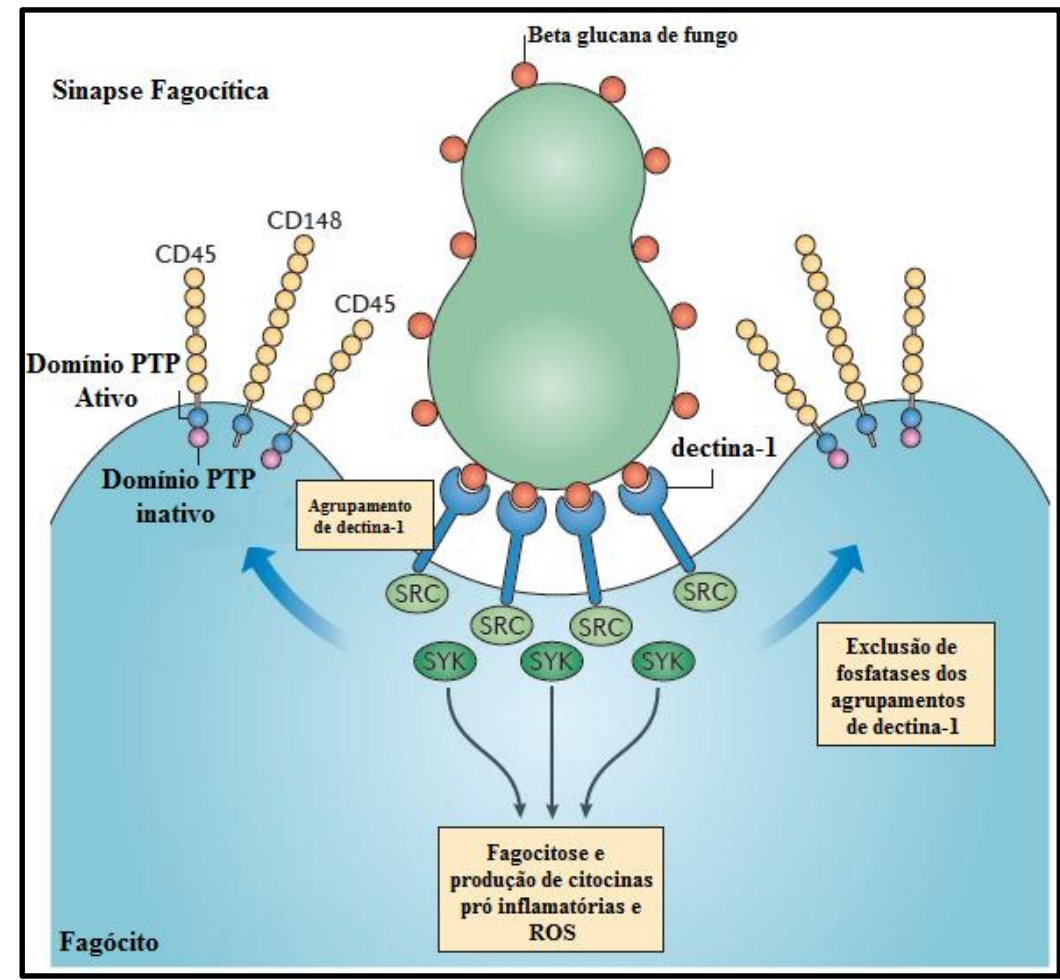

Figura 9. Esquema ilustrativo da formação da sinapse fagocítica. A resposta de dectina-1 é iniciada em um sítio de contato de uma molécula insolúvel através da formação de uma sinapse fagocítica. A via de sinalização está relacionada a um motivo denominado de hemITAM. As cascatas de tirosina quinase iniciadas após a ativação de ambos os receptores, são regulados por uma tirosina fosfatase intrínseca à membrana (CD45 e CD148), que são inicialmente requeridas para ativar a família de quinases (SRC) e recrutar a molécula adaptadora Syk continuando assim a sinalização intracelular. PTP - proteína tirosina fosfatase; ROS - espécies reativas de oxigênio. Adaptado de Goodridge et al, 2011.

Numerosos estudos demonstraram que as beta-glucanas podem potencializar a defesa da imunidade inata (Liu et al., 2008; Dubey et al., 2014; Van der Meer et al., 2015). Estas moléculas podem apresentar tanto atividade estimuladora como supressora 
(Giaimis et al., 1993; Fuentes et al., 2011). Esta atividade ambígua pode ocorrer devido às diferentes fontes e consequentemente composições químicas distintas (Volman et al., 2010), bem como na capacidade de ligar-se a diferentes TLRs e CLRs. Além disso, a literatura diverge sobre o efeito destes polissacarídeos na fagocitose, com trabalhos demonstrando o efeito inibitório (estimulo com zimosan, uma beta-glucana proveniente de Saccharomyces cerevisiae, S. cerevisiae) na fagocitose (Giaimis et al., 1993; Brown et al., 2002; Nair et al., 2006; Fuentes et al., 2011) e outros afirmando que após estímulo houve o aumento da capacidade fagocítica sobre os microrganismos alvo (Martins et al., 2008a).

A contaminação por endotoxinas é um importante aspecto referente a qualidade da amostra (isenta de contaminação) que pode interferir na atividade biológica de betaglucanas, podendo ocorrer durante o cultivo miceliar ou na preparação destas (Chan et al., 2009). A molécula lipopolisacarídeo (LPS) é um potente mediador inflamatório, ativando células imunes através dos receptores TLRs e estimulando a secreção de citocinas pró-inflamatórias, tais como TNF- $\alpha$ e Il-1 $\beta$ (Bode et al., 2012; Calil et al., 2014).

Assim, várias doenças que resultam na depressão da imunidade do hospedeiro, como àquelas causadas por fungos, causam uma severidade. Desta forma, a identificação de moléculas que estimulam a reposta imunológica do hospedeiro, como as beta-glucanas não contaminadas, é importante para estudos envolvendo estratégias de tratamento destes pacientes.

\section{Doenças fúngicas humanas}

Recentemente, os fungos patogênicos tornaram-se um problema de saúde global, com mais de trezentas espécies fúngicas associadas a infecções em humanos e em animais. As principais causas são devidas ao aumento do número pacientes imunossuprimidos e susceptíveis a essas infecções, tais como portadores de síndrome da imunodeficiência adquirida (AIDS), pacientes em uso de quimioterápicos e submetidos a transplantes, bem como à seleção de resistência pelo uso excessivo de antibióticos (Low e Rotstein, 2011). Ademais, estimativas indicam que o aquecimento global poderá 
favorecer uma maior incidência dessas infecções no planeta (Chandler e Watts, 1996; Garcia-Solache e Casadevall; 2010; Ramana et al., 2013; Bell et al. 2016).

As infecções fúngicas invasivas apesar de apresentarem uma incidência menor quando comparadas às infecções superficiais, apresentam uma taxa de mortalidade elevada (1,5 milhão de óbitos anualmente). Dentre as espécies responsáveis pelas infecções consideradas invasivas estão os gêneros Candida, Aspergillus, Pneumocytis e Cryptococcus (Brown et al., 2012; Paramythiotou et al., 2014; Rathore et al., 2016).

\section{Cryptococcus neoformans}

O nome do gênero Cryptococcus ssp. é derivado de duas palavras gregas: krypton, que significa escondido (devido à forma de transmissão não perceptível pelo ar) e kokkos, que significa semente (devido à forma esférica do microrganismo) (Offiah e Naseer, 2016). Em 1894, o fungo Cryptococcus neoformans (C. neoformans) foi isolado pela primeira vez em uma lesão de periostite tibial pelos médicos alemães Abraham Buschke e Otto Busse (revisado em Coelho et al., 2013), que o descreveu como Saccharomyces hominis (Figura 10). No mesmo período, o italiano Francesco Sanfelice também o isolou em um suco de fruta fermentado, nomeando-o de Saccharomyces neoformans (Walton et al., 2005; Lin e \& Heitman, 2006; Barnett \& Barnett, 2011).

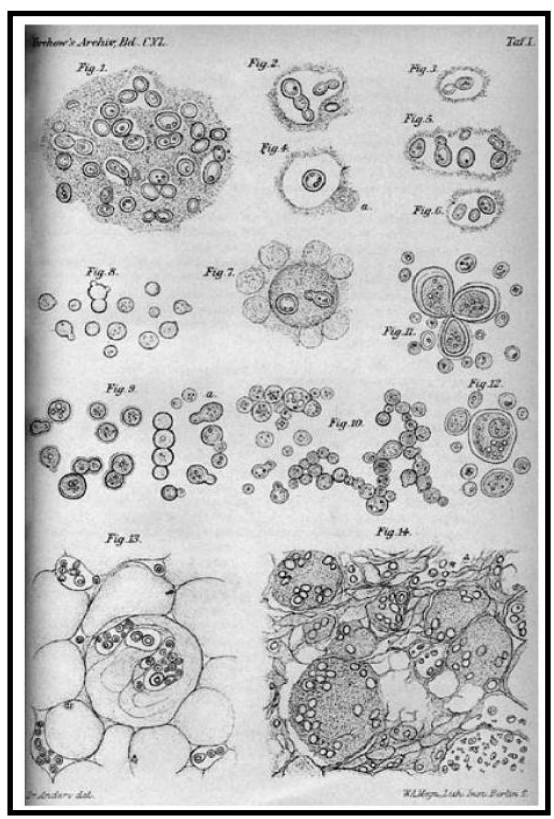

Figura 10. Primeiros desenhos de Crytococcus sp. Desenhos do patologista alemão Otto Busse em 1894. Fonte: Barnett \& Barnett, 2011. 
O médico micologista Jean Paul Vuillemin avaliou, em 1901, a nomenclatura dos fungos encontrados em 1894. Após análises, denominou o fungo Saccharomyces hominis para o nome C. neoformans e o fungo Saccharomyces neoformans para Saccharomyces litogenes (Barnett \& Barnett, 2011). Contudo, a classificação do gênero Cryptoccocus como um gênero homogêneo permaneceu a mesma até 1949, quando Evans (1950) classificou as cepas de fungos pertencentes ao mesmo gênero, devido a um ensaio de aglutinação de antígenos capsulares usando soro de coelho (Meyer et al., 2009; Barnett, 2010; Barnett \& Barnett, 2011; revisado de Santos, 2014).

A classificação de Evans foi utilizada anteriormente e é constituída por quatro sorotipos, sendo C. neoformans var. grubii sorotipo A, Cryptococcus gattii (C. gattii) sorotipos B e C e C. neoformans var. neoformans sorotipo D (Evans, 1950; Meyer et al., 2009; revisado de Santos, 2014). Em 2009, Meyer et al. Sugeriram uma nova classificação baseada em padrões moleculares, pelo sequenciamento multilocus (análise de diferentes genes entre espécies).

Embora o número de espécies do gênero Cryptococcus ser significativo, aproximadamente 30 espécies, apenas duas são agentes etiológicos da patologia causada pela criptococose: C. gatti e C. neoformans (revisado de Santos, 2014; Offiah e Naseer, 2016). Os indivíduos imunocomprometidos são acometidos pelo fungo C. neoformans, enquanto os imunocompetentes são infectados por principalmente por $C$. gatti e em alguns casos também por C. neoformans (Offiah e Nasser, 2016).

\section{Fatores de Virulência}

Os mecanismos de virulência associados à $C$. neoformans são complexos, porém importantes para o entendimento da patogenicidade do fungo. Para que o patógeno sobreviva tanto no ambiente externo quanto no hospedeiro são cruciais a efetividade do processamento de sinais e sua resposta. Assim, a resposta adequada ocorre pelas vias de transmissão de sinais, que são ativadas em resposta a diversas condições microambientais e permitem a sua sobrevivência devido a fatores de virulência (Kozubowski, et al. 2009; revisado de Barros, 2014). 
Dentre os diversos fatores de virulência de C. neoformans há: (1) a capacidade de sintetizar melanina devido a presença de compostos fenólicos, gerando proteção e estabilidade da parede celular, (2) a atividade de lipases, peptidases e DNAses, entre elas as enzimas fosfolipases (B e C) e urease, auxiliando no estabelecimento e disseminação do patógeno, (3) a capacidade de tolerância e crescimento a $37 \mathrm{C}^{\circ}$ (em geral incomum para o reino Fungi) e (4) a produção de uma cápsula polissacarídica, uma de revestimento e outra externa à parede celular (observada no gênero Crytococcus) (Cox et al., 2000; Erickson et al., 2001; Zaragoza et al., 2006; Bahn et al., 2007; Eisenman et al., 2007; Robert e Casadevall, 2009; Djordjevic, 2010; Almeida et al., 2015).

A capsula polissacarídica é composta por três tipos de polissacarídeos: manoproteínas, galactoglicoxilomananas (GalGXM) e GXM (Glucuronoxilomanana), que compõem 90-92\% da massa capsular (O’Meara e Alspaugh, 2012). Estes carboidratos protegem o fungo contra o sistema imunológico do hospedeiro (por exemplo a fagocitose), de predadores (fagocitose de amebas e nemátodos) e do ambiente (dessecação) (Steenbergen et al., 2003; Zaragoza et al., 2008; revisado de Barros, 2014).

No hospedeiro, a cápsula atua interferindo no sistema imunológico e protegendose de mecanismos efetores do sistema imune. A interferência a nível imunológico ocorre de diferentes maneiras, tais como: produzindo propriedades antifagocitárias, inibindo a produção de anticorpos, depletando o complemento, diminuindo a capacidade de apresentação antigênica por monócitos, inibindo a migração de leucócitos, por meio da indução da apoptose em macrófagos e células $\mathrm{T}$ e pela inibição da ação de espécies reativas de oxigênio e nitrogênio de macrófagos (Zaragoza, 2011; O'Meara e Alspaugh, 2012).

De fato, a estrutura e o tamanho da cápsula são dependentes da localização de $C$. neoformans. O papel do crescimento da cápsula no meio ambiente é incerto, porém relatos da literatura indicam que o crescimento ocorre como um mecanismo de proteção contra dessecação ou como uma fonte de nutrientes. Uma vez no hospedeiro, o fungo sobrevive aumentando a espessura da cápsula, protegendo-o de hipóxia, acidificação do meio e depleção de ferro e glicose, mecanismos produzidos pelo sistema imune (Feldmesser et al., 2001; Kozel et al., 2003; Zaragoza et. al., 2008; O’Meara e Alspaugh, 2012; Almeida et al., 2015). 
As cepas de $C$. neoformans não capsuladas são raramente observadas em isolados de amostras clínicas e mutações específicas na formação da cápsula resultam em uma redução significativa na virulência de C. neoformans (O’Meara e Alspaugh, 2012), demonstrando a importância desta estrutura tanto para o patógeno quanto para a patologia.

\section{Criptococose}

Um estudo demonstrou que crianças na faixa etária de 2 a 5 anos de idade entraram em contato e produziram anticorpos contra o fungo C. neoformans. Este trabalho indicou ainda que a primeira infecção poderia ocorrer durante este período avaliado (Goldman, 2001). Ademais, outro estudo de cunho epidemiológico demonstrou que o número de casos de criptococose em pessoas saudáveis variou entre dois a nove casos a cada 1 milhão de indivíduos, enquanto que entre pessoas imunodeficientes a incidência foi de 17 a 66 mil casos a cada 1 milhão de indivíduos infectados com a HIV (Goldman, 2001). Deste modo, estes resultados demonstraram como a deficiência da resposta imune pode influenciar em uma diferença importante no número de casos entre os indivíduos imunocompetentes e aqueles imunologicamente comprometidos.

Desde 1980, o número de casos envolvendo o fungo C. neoformans apresenta um aumento significativo, principalmente em pacientes imunossuprimidos acometidos pela AIDS (Barnett e Barnett, 2011) e em tratamento quimioterápico (Bovers et al., 2008; revisado de Barros, 2014). Em 1990, a combinação de medicamentos antifúngicos (anfotericina) e de antirretrovirais diminuiu o número de casos. Contudo, em lugares cujo acesso aos medicamentos antirretrovirais é inconstante ou inexistente, como partes da Ásia e África subsaariana, os números continuaram crescentes (Park et al., 2009; Jackson et al., 2012; Rohatgi \& Pirofski, 2015).

Historicamente, a maioria dos casos de criptococose mundialmente é causada por C. neoformans var. grubii e var neoformans, exceto na Austrália (Lin e Heitman, 2006). Em 2015, uma estimativa global relatou que o número de óbitos de criptococose foi de 233 mil (Denning, 2016). Do total de pacientes infectados com HIV no mundo, 40\% apresentaram a criptococose meningocócica no ano 2000 (Powderly, 2000). Nos Estados 
Unidos, a meningite criptocócica foi diagnosticada em $8 \%$ dos casos de pacientes com HIV, que resultou em uma taxa de morbidade e mortalidade significante entre 1997 a 2009 (Pyrgos et al 2013; Rohatgi \& Pirofski, 2015). Apesar do tratamento, a meningite criptocócica é letal para 20\% dos pacientes em um período de dois meses (Perfect et al., 2010). No Brasil, 5.898 óbitos foram associados a micoses sistêmicas entre 1998 e 2006. As principais doenças fúngicas relacionadas aos obtidos foram: (1) criptococose $(50,9 \%$ dos casos), candidíase (30,2\%) e (3) histoplasmose (10,1\%) (Prado et al., 2009, revisado de Santos, 2014).

As infecções de fungos patogênicos estão associadas a uma alta taxa de mortalidade, como no caso de Candida anbicans (20-50\%), C. neoformans (20-70\%) e Aspergillus fumigatus (50-90\%) (Balloy e Chignard, 2009; Arendrup et al., 2011; Brown et al., 2012; Tripathi e Meena., 2014; Filipuzzi et al., 2016), principalmente em indivíduos imunocomprometidos (Brown et al., 2012; Hope et al., 2013). As doenças fúngicas ocorrem principalmente pela inalação de conídios infectantes com um a cinco $\mu \mathrm{m}$ de diâmetro, atingindo os espaços alveolares e o interstício pulmonar no trato respiratório superior (Barbosa et al., 2006; Griffiths et al, 2012). Além do trato respiratório ser a via primária de infecção, esta pode ocorrer por trauma ou transplante de órgãos infectados. Apesar de os casos de grávidas infectadas com criptococose serem incomuns, a transmissão placentária também pode ocorrer (Desalermos et al., 2012; Patel et al., 2012; Kiggundu et al., 2014).

Uma vez nos pulmões, as leveduras são fagocitadas por macrófagos alveolares, podendo ocorrer a disseminação hematogênica, que permite ao fungo atingir qualquer órgão, principalmente o sistema nervoso central para o qual o patógeno apresenta tropismo (Hull e Heitman, 2002). A figura 11 demonstra o ciclo de infecção de $C$. neoformans. 


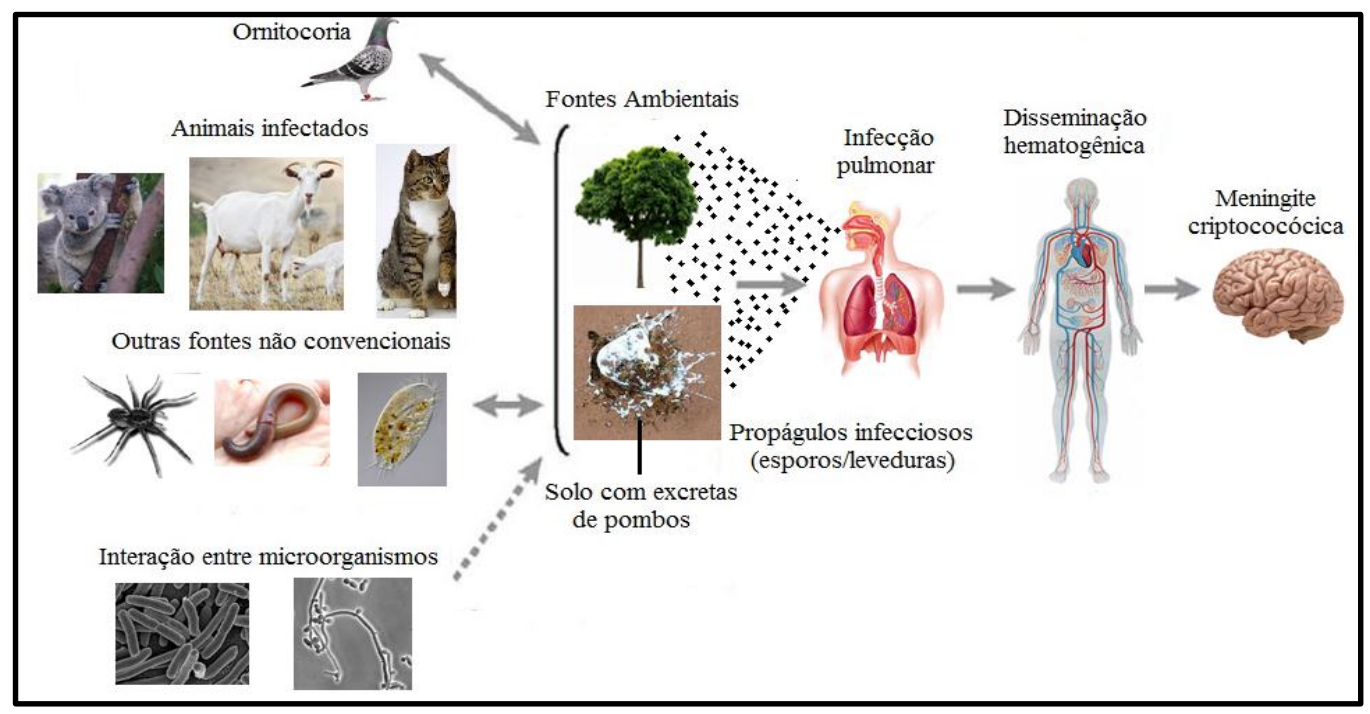

Figura 11. Ciclo de infecção de Cryptococcus envolvendo o ambiente e hospedeiro. No solo, associado às excretas de aves (principalmente pombos) ou em árvores, o fungo consegue sobreviver. Outros animais (gatos, cabras e coalas) também são considerados dispersores. A espécie C. neoformans é capaz de sobreviver em associação a outros organismos (insetos, amebas e minhocas), podendo interagir com bactérias e outros fungos. Uma vez estabelecido o imunocomprometimento, o fungo é capaz de tornar-se reativo no hospedeiro, dispersando-se por meio da corrente sanguínea e atingindo o sistema nervoso central. Adaptado de Lin e Heiman (2006).

Em hospedeiros imunocompetentes, a criptococose é assintomática e restrita nos pulmões. Contudo, na deficiência de uma resposta imune efetiva o fungo pode utilizar seus fatores de virulência e difundir-se para outros órgãos e tecidos (fígado, trato urinário, trato gastrointestinal, pele, olhos, glândulas adrenais, ossos, próstata, coração, linfonodos e articulações). Ademais, o cérebro é o segundo local mais infectado, causando a meningoencefalite (meningite) (Chen et al., 2000; Lin e Heitman, 2006; Casadevall et al., 2009; Zaragoza et al., 2011). O fato de o número de casos de criptococose (doença causada pelo fungo Cryptococcus ssp.) aumentar consideravelmente nos imunossuprimidos influenciou nas pesquisas voltadas para a compreensão desta doença. Entre 1947 e 2011 foram publicados mais de 9.000 estudos que influenciaram positivamente no avanço do conhecimento biológico da resposta imune do hospedeiro à C. neoformans (Barnett e Barnett, 2011; Rohatgi e Pirofski, 2015). 


\section{Imunologia da Criptococose}

Diferentes fungos infectam os seres humanos, podendo viver dentro de fagócitos e em tecidos extracelulares. Em indivíduos saudáveis, o patógeno é contido de forma eficiente após a infecção, mas não é erradicado completamente, gerando a reação imune granulomatosa e permanecendo assim de forma latente no hospedeiro (Dromer et al., 2011). Neste contexto, a imunidade inata atua como a primeira linha de defesa do hospedeiro contra o patógeno. Os principais mediadores da imunidade inata contra os fungos são: os neutrófilos, os macrófagos e as células dendríticas, atuando cada um de forma distinta (Abbas et al., 2015).

As células dendríticas agem no reconhecimento e internalização do fungo. Neste contexto, por meio do reconhecimento de células dendríticas, muitos fungos induzem uma resposta Th17, secretando IL-6 e IL-23, estimulando a inflamação e o recrutamento de neutrófilos e monócitos que eliminam fungos extracelulares (Abbas et al., 2015). Contudo, C. neoformans é um fungo patogênico intracelular. Neste caso, as células dendríticas são responsáveis pela comunicação entre a resposta imune inata e adaptativa, a partir da apresentação de antígenos para a ativação de linfócitos $\mathrm{T} \mathrm{CD}^{+}$e $\mathrm{T} \mathrm{CD} 8^{+}$ (Wozniak, 2006; Voelz e May, 2010; Coelho et al., 2013). Adicionalmente, o componente capsular GXM inibe a sinalização da molécula adaptadora Syk, interferindo no receptor do complexo inflamassoma NLRP3 e facilitando o parasitismo intracelular do fungo (Guo et al., 2014, Tavares et al., 2015).

Embora mais de $80 \%$ das leveduras sejam fagocitadas por macrófagos alveolares num período de aproximadamente 4 horas (Feldmesser et al., 2000), o mecanismo de eliminação não ocorre de forma eficiente, permitindo que o patógeno sobreviva nas células fagocíticas (Levitz et al., 1999). Outros mecanismos de resistência relacionados à interação $C$. neoformans e macrófago foram descritos, tais como (1) capacidade de permanecer e proliferar no fagolisossomo ativado; (2) disseminar-se sistemicamente a partir da permanência do fungo no interior do macrófago e (3) a exocitose não lítica (capacidade de evasão do interior do macrófago sem danos celulares (Voelz e May, 2010; Johnston e May, 2010). 
Além de fagocitar, os macrófagos secretam citocinas e quimiocinas para recrutar outras células do sistema imunológico, modular a resposta e apresentar antígenos (Vecchiarelli, 2000; He et al., 2003; Siddiqui et al., 2006). A imunidade mediada por células é o principal mecanismo da imunidade adaptativa contra infecções fúngicas (Romani et al., 2011; Davis et al., 2013).

Posteriormente à resposta imune inata, a imunidade adaptativa é ativada e células $\mathrm{T} \mathrm{CD}^{+}{ }^{+}$sinalizam para a produção de citocinas do tipo Th1, como TNF- $\alpha$ e IFN- $\gamma$. Neste processo inflamatório, as citocinas estimulam a produção de macrófagos classicamente ativados (M1), aumentando assim a atividade efetora e resposta contra a criptococose, além de manter a infecção sob controle (Vecchiarelli, 2000). Ademais, as células T CD4 ${ }^{+}$ e CD $8^{+}$cooperam para eliminar as leveduras de $C$. neoformans que colonizam os pulmões e o cérebro em imunodeficientes. Todavia, $C$. neoformans pode inibir a produção de citocinas, tais como TNF- $\alpha$ e a IL-12, e estimula a produção da interleucina 10 (IL-10), inibindo a ativação destes macrófagos (Abbas, et al., 2015). Os macrófagos podem também ser expostos a citocinas do tipo Th2, como interleucina 4 (IL-4) e interleucina 13 (IL-13), gerando a ativação de macrófagos alternativos (M2) que não são suficientes para controlar a replicação fúngica, favorecendo-a (Muller et al., 2007).

A resposta protetora observada nesta doença é mediada pela produção de anticorpos (Casadevall e Pirofski, 2012), cuja importância foi relatada pela primeira vez na literatura em 1980. Os primeiros anticorpos monoclonais produzidos foram contra o polissacarídeo GXM (Casadevall et al., 1992) e posteriormente foram propostos como uma alternativa terapêutica, uma vez que demonstraram proteção em camundongos infectados (Casadevall et al., 1998). Os mecanismos envolvidos nesta proteção envolvem a opsonização, a fixação de complemento na superfície do fungo e toxicidade celular mediada por anticorpos (Casadevall e Pirofski, 2007).

A cápsula polissacarídica que reveste $C$. neoformans, impede que este seja englobado por fagócitos (macrófagos e neutrófilos) do hospedeiro, na ausência de opsoninas. Além disso, os polissacarídeos GXM e GalXM são secretados para o meio externo no qual o fungo se encontra, interferindo na atividade de linfócitos $\mathrm{T}$ e macrófagos e prejudicando a resposta imune efetora (Kozel et al., 1988; Vecchiarelli et al., 2007). 
Recentemente, foi descrito que a interação de polissacarídeos presentes na parede celular dos fungos com o sistema imunológico do hospedeiro é capaz de ativar tanto a resposta inata como a adaptativa, devido ao seu potente efeito imunoestimulatório (Dalmo e Bogwald, 2008; Ramberg et al., 2010; Ferreira et al., 2015). Em 2014, mais de 7.000 publicações voltadas para os efeitos biológicos de diferentes beta-glucanas foram relatadas na literatura. Contudo, a obtenção dessas beta glucanas não é reprodutível devido a vários fatores, tais como processo de obtenção, quantificação e controle de qualidade. Assim essas diferenças prejudicam o aceite da comunidade científica e médica, uma vez que apresentam características distintas como solubilidade, tamanho molecular, cadeias laterais bem como outras características físico-químicas (Vetvicka et al., 2014a).

Apesar da capacidade imunoestimulatória das beta-glucanas, os fungos patogênicos humanos impedem a ativação adequada do sistema imunológico do hospedeiro, subvertendo ou mascarando estes polissacarídeos da parede celular, contribuindo para a adaptação fúngica oportunista, como nos casos das infecções causadas pelos fungos Candida albicans, Histoplasma capsulatum, Paracoccidioides brasiliensis, C. neoformans, dentre outros (Vecchiarelli, 2007; Rappleye e Goldman, 2008; Levitz, 2010; Romani, 2011).

Além do reconhecimento ineficiente do C. neoformans, sua eliminação também é dificultada pelas estratégias de tratamento, uma vez que os fármacos utilizados atualmente para o tratamento das infecções fúngicas apresentam eficácia e biodisponibilidade limitadas, pequeno espectro de atuação e alta toxicidade (Odds, 2003; Sheng, 2011). Ademais, o desenvolvimento de novas drogas seletivas contra fungos, especialmente alvos proteicos, tem se mostrado desafiador devido à evolução conservada entre estes e o homem, o que resulta em um número limitado de alvos biológicos (Denning e William, 2010).

O papel de agonistas na imunomodulação do hospedeiro (como os polissacarídeos) é atualmente estudado, uma vez que estes poderiam potencializar a resposta imunológica à infecção fúngica (Antachopoulos e Walsh, 2012). Contudo, a diversidade de estudos utilizando beta-glucanas é um desafio, o que poderia ser resolvido realizando estudos comparativos. Entretanto, poucos trabalhos comparam a atividade biológica de diferentes fontes de beta-glucanas (Vetvicka et al., 2014b; Zhao et al., 2014). Esta divergência foi abordada por Vetvicka et al. (2010), indicando que as beta-glucanas 
não são obtidas igualmente, que diversas fontes comerciais apresentam baixa atividade biológica, algumas moléculas apresentam diferentes efeitos biológicos baseado em características testadas, e principalmente, não houve relevância clara entre as fontes de beta-glucana e a atividade observada. Portanto, novos estudos comparativos sobre diferentes fontes de beta-glucanas são necessários para elucidar divergências sobre atividades biológicas e imunológicas distintas. 


\section{OBJETIVO}

Sabendo que a depressão do sistema imunológico está associada à ineficácia da proteção do hospedeiro a infecções fúngicas e às limitações terapêuticas, a utilização de moléculas agonistas com efeito imunoestimulatório potente, como o caso dos polissacarídeos oriundos de cogumelos, ativariam o sistema imune e desencadearia uma resposta pró-inflamatória equilibrada que poderia auxiliar na resposta imunitária no curso de diversas doenças, no caso dos fungos patogênicos humanos. Considerando que os polissacarídeos são capazes de ativar e modular o sistema imunológico inato, o objetivo do presente trabalho foi obter e caracterizar exopolissacarídeos dos basidiomicetos Ganoderma lucidum e Auricularia auricula e avaliar sua capacidade de modular o sistema imunológico do hospedeiro imunocompetente, bem como da resposta imune do hospedeiro infectado pelo fungo patogênico Cryptococcus neoformans.

Objetivos específicos:

1- Produzir polissacarídeos dos basidiomicetos Auricularia auricula e Ganoderma lucidum bem como caracterizar as moléculas obtidas quanto a sua composição e estrutura.

2- Avaliar a capacidade imunomodulatória dos polissacarídeos obtidos dos basidiomicetos Auricularia auricula e Ganoderma lucidum em células da imunidade inata.

3- Avaliar a atividade imunomodulatória dos polissacarídeos obtidos dos cogumelos A. auricula e G. lucidum frente ao fungo patogênico C. neoformans e no curso da criptococose. 


\section{RESULTADOS E DISCUSSÃO}

\section{PARTE 1 - Caracterização da das beta-glucanas obtidas pelos basidiomicetos $G$.}

lucidum e A. auricula.

Nesta seção foi padronizada a metodologia para o cultivo submerso sob estresse; analisada a composição monossacarídica e a caracterização da estrutura dos exopolissacarídeos obtidos após o processo de produção.

\subsection{MATERIAIS E MÉTODOS}

\section{Cogumelos}

Os cogumelos A. auricula (cc 309) e G. lucidum (cc 359) foram obtidos no Banco de Germoplasma de Cogumelos para Uso Humano da Empresa Brasileira de Pesquisa Agropecuária (EMBRAPA), Unidade Recursos Genéticos e Biotecnologia - Cenargen, sob coordenação da Dra. Arailde Fontes Urben. O termo de autorização de acesso de patrimônio genético (número 010342/2014-1, Anexo 9.1) foi concedido pelo Conselho Nacional de Desenvolvimento Científico e Tecnológico - CNPq.

\section{Produção de polissacarídeos}

Os cogumelos foram cultivados pela técnica de cultivo submerso. As cepas fúngicas isoladas permaneceram a 28 graus Celsius $\left({ }^{\circ} \mathrm{C}\right)$ em placas contendo meio batata dextrose (Acumedia, ref. 7585A) ágar (Merck, ref. VM887114) e após crescimento foram armazenadas a $4{ }^{\circ} \mathrm{C}$.

Para a obtenção do pré-inóculo, fragmentos de micélio crescidos em meio de cultivo sólido (2 centímetros $(\mathrm{cm})$ por $2 \mathrm{~cm}$ ) foram adicionados a 100 mililitros $(\mathrm{mL}) \mathrm{de}$ meio batata dextrose líquido estéril, contendo agente seletivo ácido lático filtrado (concentração final de $28 \%$, P.V.) (J.T.Baker, Ref. 0194-01) e cultivados a $30^{\circ} \mathrm{C}$, por 130 rotações por minuto (RPM), durante sete dias. Após este período, o inóculo foi preparado 
a partir do pré-inóculo, contendo $500 \mathrm{~mL}$ de meio batata dextrose líquido estéril e agente seletivo na mesma concentração e condições de crescimento do pré-inóculo.

Após o período de crescimento, os micélios obtidos foram centrifugados em tubos falcon de $50 \mathrm{~mL}$ estéreis à $6.188 \mathrm{x} \mathrm{g}, 4^{\circ} \mathrm{C}$ por 12 minutos e o sobrenadante foi descartado. Em seguida, os micélios foram lavados com água destilada, os tubos foram centrifugados à $6.188 \mathrm{x} \mathrm{g}, 4^{\circ} \mathrm{C}$ por 12 minutos e o sobrenadante foi descartado. Esta etapa se repetiu mais duas vezes. Após a lavagem foram adicionados ao micélio $500 \mathrm{~mL}$ de meio estressor denominado de meio de cultivo mínimo nutricional estéril (processo em pedido de patente). Em seguida, o micélio permaneceu sob cultivo por 24 horas, a $130 \mathrm{rpm}$ à $30^{\circ} \mathrm{C}$. Posteriormente ao período de incubação, o meio contendo micélio foi centrifugado a $6.188 \times \mathrm{g}, 4^{\circ} \mathrm{C}$ por 12 minutos. $\mathrm{O}$ micélio foi descartado e o sobrenadante foi filtrado (papel filtro qualitativo, J.Prolab) e armazenado a $-20^{\circ} \mathrm{C}$. Após o congelamento o material foi liofilizado e armazenado a $-20^{\circ} \mathrm{C}$ para análises posteriores. A separação das frações quanto a solubilidade ocorreu adicionando água destilada e solubilização dos polissacarídeos solúveis. Em seguida as frações solúveis e insolúveis são centrifugadas a $5.000 \mathrm{rpm}, 4^{\circ} \mathrm{C}$, por 10 minutos. O sobrenadante foi coletado e o precipitado contendo a fração insolúvel foi solubilizada com água destilada.

\section{Quantificação de carboidratos}

A quantificação dos polissacarídeos obtidos foi feita pela reação colorimétrica baseado em DuBois et al. (1956), com modificações. Basicamente, 50 microlitros $(\mu \mathrm{L})$ de amostras foram adicionados a $500 \mu \mathrm{L}$ de fenol $4 \%$ e $2,5 \mathrm{~mL}$ de ácido sulfúrico. Em

seguida as amostras foram homogeneizadas por 10 segundos e lidas em espectrofotômetro no comprimento de onda de 490 nanômetros.

\section{Composição monossacarídica e caracterização estrutural}

A análise dos constituintes monossacarídicos obtidos dos cogumelos foi feita utilizando a técnica de cromatografia em fase gasosa acoplada a espectrometria de massa (GC-MS), baseando-se em Bitencourt (2015). Resumidamente, os espectros foram obtidos comparando o tempo de detecção das moléculas padrão de monossacarídeos 
(Tabela 3) e o tempo de retenção das amostras avaliadas. Estas análises foram feitas no Laboratório de Produtos Naturais da Universidade Federal de Goiás (UFG), unidade Catalão, sob a coordenação da professora Dra. Elaine Carbonero.

Tabela 3. Monossacarídeos padrão e os tempos de retenção utilizando a coluna HP5.

\begin{tabular}{|c|c|c|c|}
\hline & \multicolumn{2}{|c|}{$\begin{array}{c}\text { Monossacarídeos } \\
\text { Controle }\end{array}$} & $\begin{array}{l}\text { Tempo de } \\
\text { retenção }\end{array}$ \\
\hline \multirow{2}{*}{ 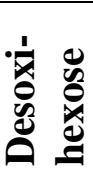 } & Rha & Ramnose & 17.168 \\
\hline & Fuc & Fucose & 17.310 \\
\hline \multirow{3}{*}{ 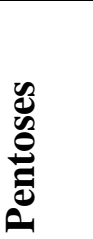 } & Rib & Ribose & 17.209 \\
\hline & Ara & Arabinose & 17.363 \\
\hline & Xyl & Xilose & 17.655 \\
\hline \multirow{3}{*}{ 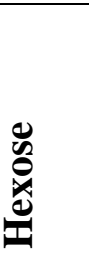 } & Man & Manose & 22.757 \\
\hline & Gal & Galactose & 23.338 \\
\hline & Glc & Glicose & 23.064 \\
\hline
\end{tabular}

A caraterização estrutural dos carboidratos solúveis e insolúveis de A. auricula ocorreu pela técnica de ressonância magnética nuclear (RMN), baseando-se em Nyman et al. (2016). As análises foram feitas no Instituto de Bioquímica Médica Leopoldo de Meis e Hospital Universitário Clementino Fraga Filho da Universidade Federal do Rio de Janeiro (UFRJ) sob a coordenação professor Dr. Vitor Hugo Pomin. 


\section{RESULTADOS}

Análise da produção e composição monossacarídica das frações de A. auricula e G. lucidum.

Os cogumelos cresceram por meio da técnica de cultivo submerso e após estresse os polissacarídeos totais exsudatos foram quantificados, cujo rendimento de carboidratos totais por litro foi aproximadamente de 90 miligramas $(\mathrm{mg})$ de fração solúvel e $40 \mathrm{mg}$ de fração insolúvel de A auricula e $50 \mathrm{mg}$ de fração solúvel e $43 \mathrm{mg}$ de fração insolúvel de G. lucidum. Os monossacarídeos presentes nas frações solúveis e insolúveis obtidos pela análise de GC-MS de A. auricula e G. lucidum estão descritos na tabela 4 e nas figuras 12 e 13 .

Tabela 4. Composição monossacarídica das frações de Ganoderma lucidum e Auricularia auricula.

\begin{tabular}{|c|c|c|c|c|c|c|c|c|c|}
\hline \multirow{2}{*}{ Cogumelo } & \multirow{2}{*}{ Amostra } & \multicolumn{8}{|c|}{ Monossacarídeos (mol\%) } \\
\hline & & Rha & Fuc & Rib & $\overline{\text { Ara }}$ & $\overline{\mathrm{Xyl}}$ & Man & Gal & Glc \\
\hline \multirow{3}{*}{$\begin{array}{c}\text { Auricularia } \\
\text { auricula }\end{array}$} & Frac̃̃o & & 12,1 & & & 8,0 & 24,3 & 10,9 & 25,2 \\
\hline & insolúvel & - & $\begin{array}{c}- \\
20,1\end{array}$ & - & 3,7 & $\begin{array}{c}- \\
19,3\end{array}$ & $\begin{array}{c}- \\
27,3\end{array}$ & $\begin{array}{c}- \\
15,4\end{array}$ & $\begin{array}{c}- \\
33,7\end{array}$ \\
\hline & $\begin{array}{l}\text { Fração } \\
\text { solúvel }\end{array}$ & - & $\begin{array}{c}22,1 \\
- \\
27,9 \\
\end{array}$ & 1,7 & - & $\begin{array}{c}7,1 \\
- \\
8,4 \\
\end{array}$ & $\begin{array}{c}23,4 \\
- \\
24,1 \\
\end{array}$ & $\begin{array}{c}21,3 \\
- \\
24,9 \\
\end{array}$ & $\begin{array}{c}18,8 \\
- \\
19,3 \\
\end{array}$ \\
\hline \multirow{2}{*}{$\begin{array}{c}\text { Ganoderma } \\
\text { lucidum }\end{array}$} & $\begin{array}{c}\text { Fração } \\
\text { insolúvel }\end{array}$ & - & 2,9 & 1,3 & - & $\begin{array}{c}\text { traços } \\
- \\
8,3\end{array}$ & $\begin{array}{c}22,1 \\
- \\
32,2\end{array}$ & $\begin{array}{c}15,7 \\
- \\
23,7\end{array}$ & $\begin{array}{c}39,6 \\
- \\
54,2\end{array}$ \\
\hline & $\begin{array}{l}\text { Fração } \\
\text { solúvel }\end{array}$ & - & $\begin{array}{c}3,1 \\
- \\
3,3\end{array}$ & 1,6 & 1,2 & 6,2 & $\begin{array}{c}35,9 \\
- \\
45,7\end{array}$ & $\begin{array}{c}21,2 \\
- \\
29,8\end{array}$ & $\begin{array}{c}22,0 \\
- \\
30,0\end{array}$ \\
\hline
\end{tabular}

Rha - Ramnose, Fuc - Fucose, Ara - Arabinose, Xyl - Xilose, Man - manose, Gal - Galactose, glc Glicose. Experimento realizado em triplicata técnica. 

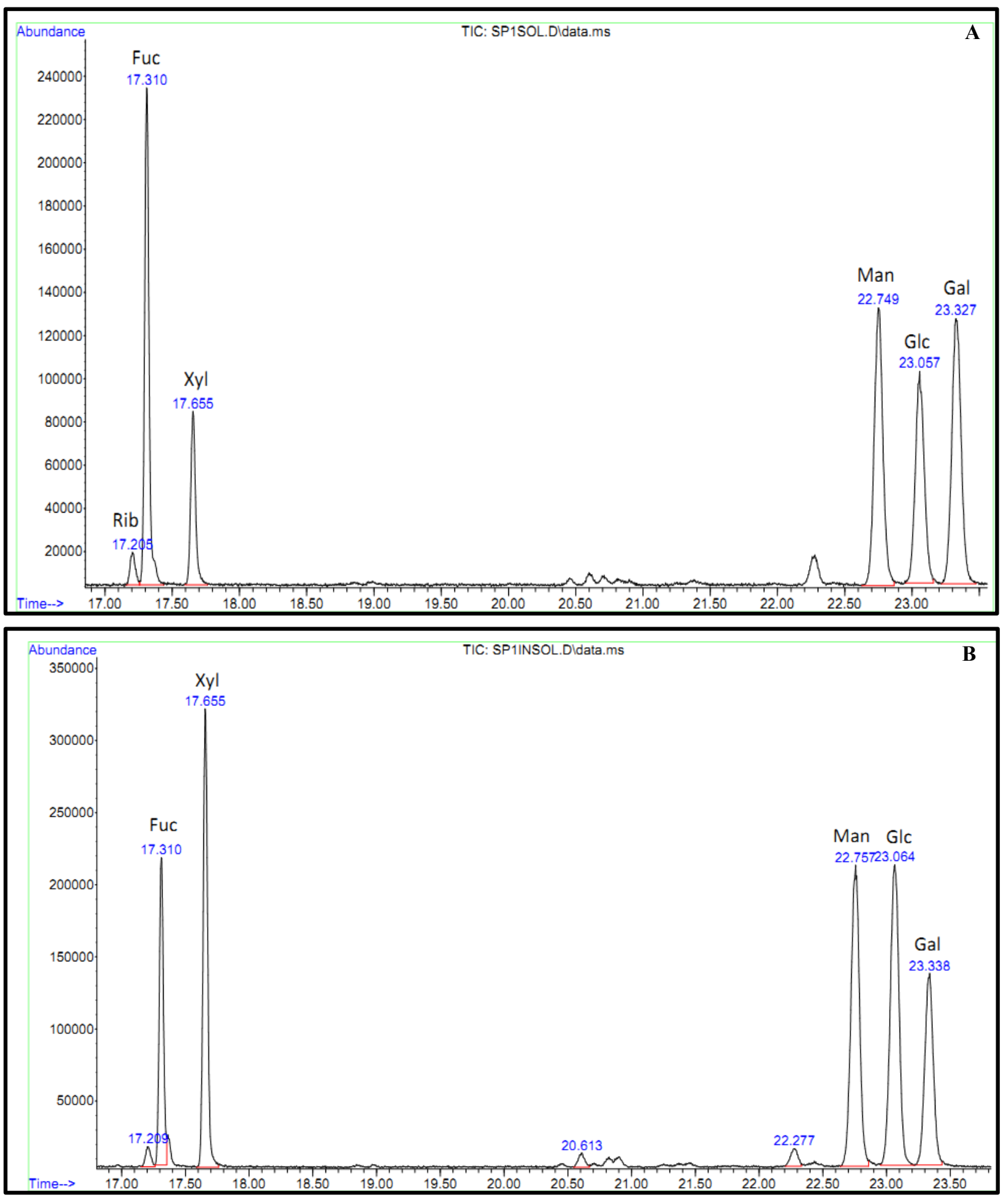

Figura 12. Avaliação dos constituintes monossacarídicos das frações solúveis e insolúveis de Auricularia auricula. A análise foi feita pela técnica de GC-MS dos constituintes monossacarídicos das frações solúveis (A) e insolúveis (B) de A. auricula. Fuc - Fucose; Xyl - Xilose; Man - Manose; Glc Glicose; Gal - Galactose; Rib - Ribose. 

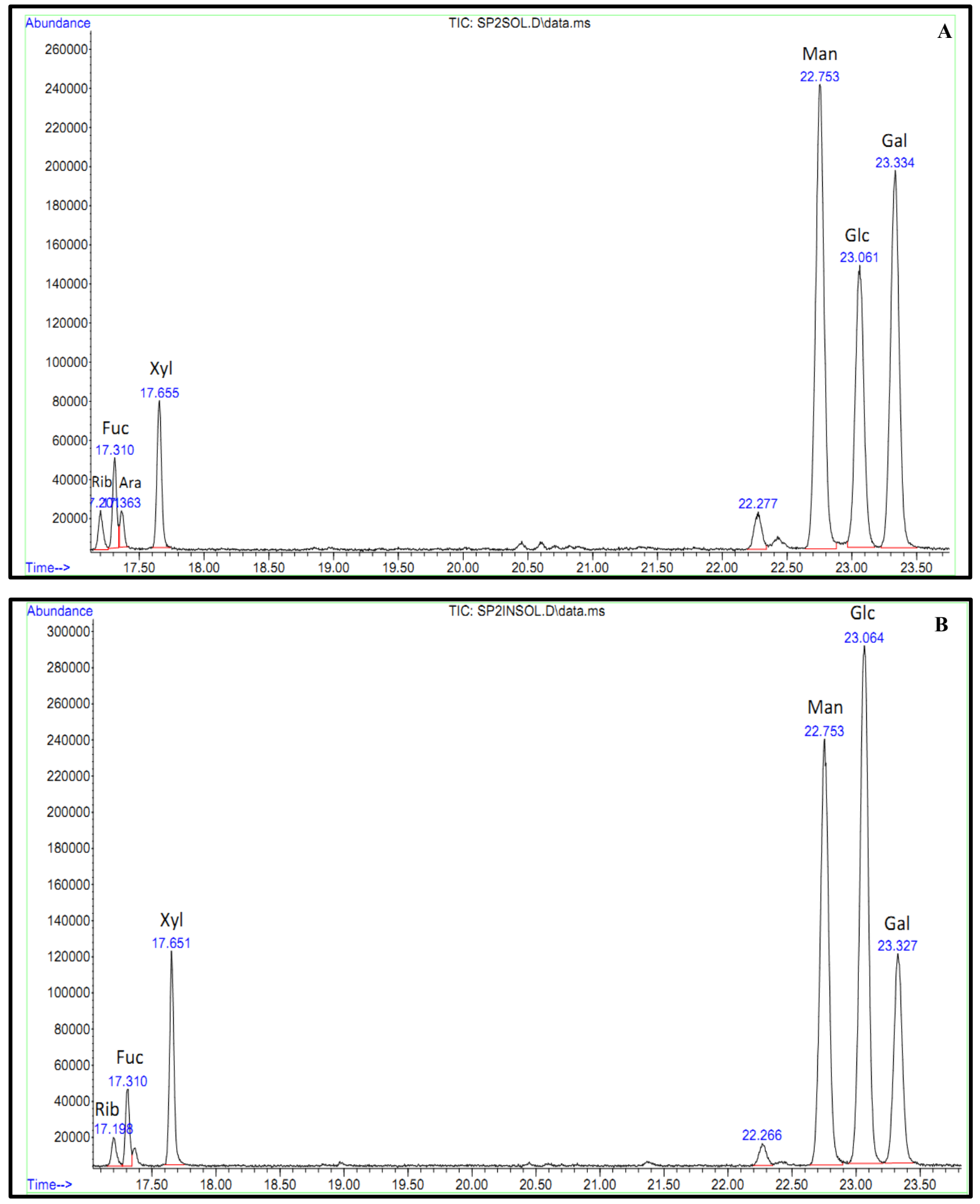

Figura 13. Avaliação dos constituintes monossacarídicos das frações solúveis e insolúveis de Ganoderma lucidum. A análise foi feita pela técnica de GC-MS dos constituintes monossacarídicos das frações solúveis (A) e insolúveis (B) de G. lucidum. Fuc - Fucose; Xyl - Xilose; Man - Manose; Glc Glicose; Gal - Galactose; Rib - Ribose; Ara - Arabinose. 
Os principais monossacarídeos observados nos experimentos foram fucose, xilose, manose, galactose e glicose. Os monossacarídeos mais abundantes das frações solúveis foram fucose, manose, galactose e glicose e das frações insolúveis foram glicose e manose (Tabela 4).

\section{Análise estrutural dos polissacarídeos de Auricularia auricula}

As figuras 14 e 15 demonstram as análises das frações solúveis e insolúveis de $A$. auricula pela técnica de ressonância magnética nuclear e a identificação dos assinalamentos dos açúcares glicose e manose.

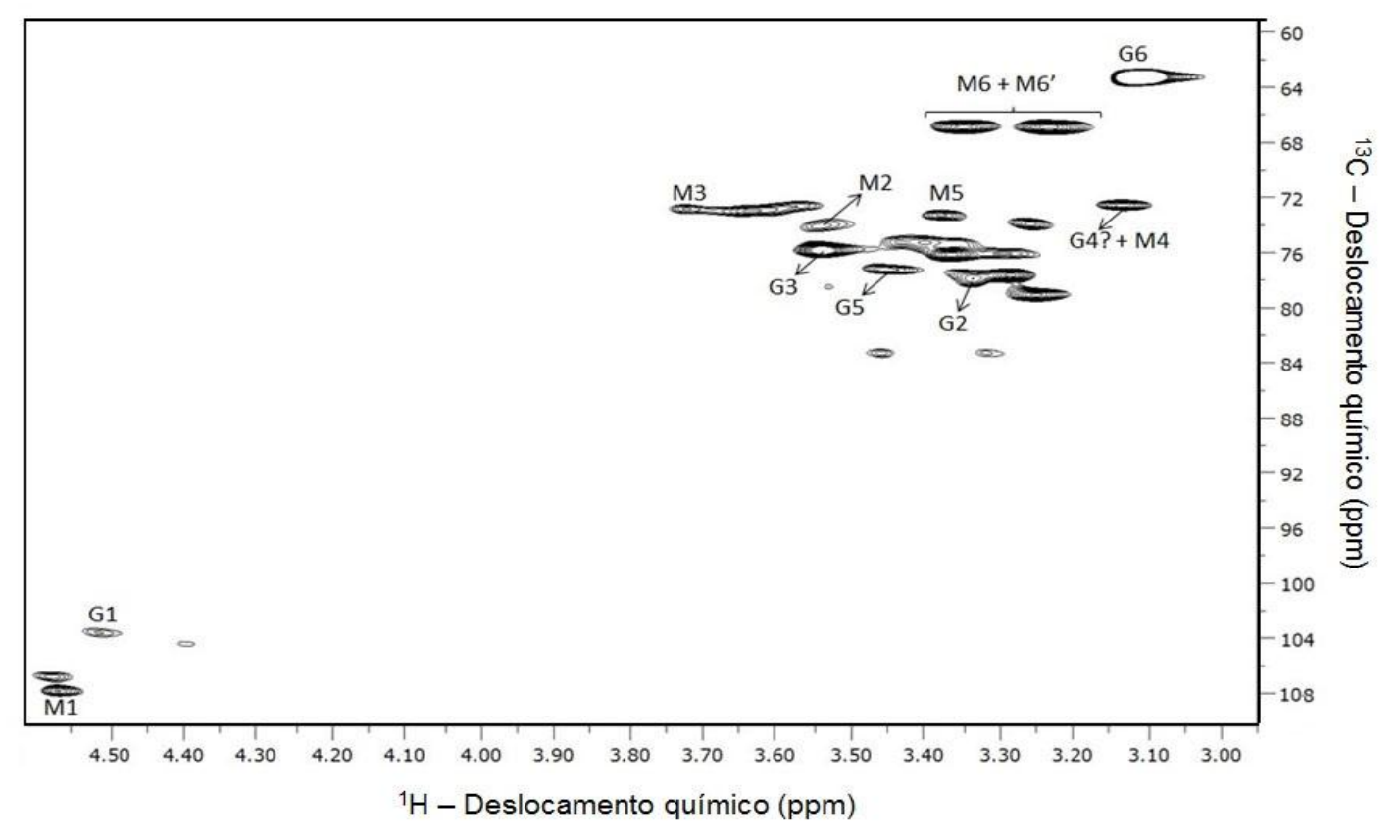

Figura 14. Espectro de RMN 2D- ${ }^{1} \mathbf{H}^{13} \mathbf{C}$ HSQC da fração solúvel de $\boldsymbol{A}$. auricula. ( $\delta_{\mathrm{H}}: 4.9$ a $\left.2.1 \mathrm{ppm}\right)$. No painel superior podemos ver o espectro da amostra com os assinalamentos feitos para os resíduos de Glcp (G). No painel inferior os assinalamentos obtidos para os resíduos de $\operatorname{Man} p(\mathrm{M})$. O numero após a letra refere-se ao $1 \mathrm{H}$ respectivo no anel glicosídico. Os espectros foram gravados em um espectrômetro Bruker $500 \mathrm{MHz}$ Avance III a $298 \mathrm{~K}$. 


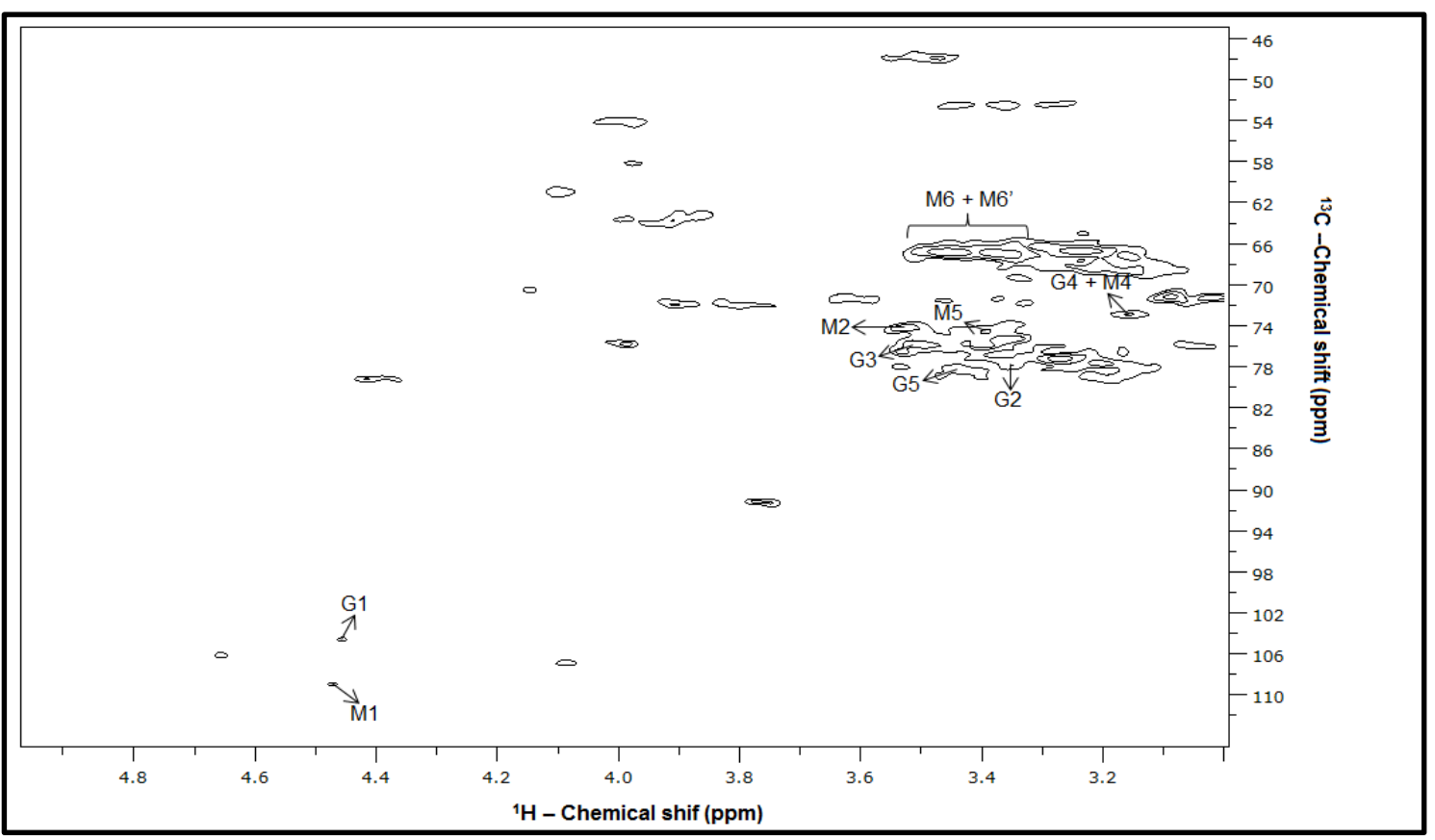

Figura 15. Espectro de RMN 2D- ${ }^{1} \mathrm{H}^{13} \mathrm{C}$ HSQC da fração insolúvel de Auricularia auricula $\left(\delta_{\mathrm{H}}: 3.0 \mathrm{a}\right.$ $5.0 \mathrm{ppm} ; \delta_{\mathrm{C}}: 45.0$ a $\left.115 \mathrm{ppm}\right)$. No painel podemos ver o espectro da amostra com os assinalamentos feitos para os resíduos de glicopiranose $(\mathrm{G})$ e os assinalamentos obtidos para os resíduos de manopiranose (M). $\mathrm{O}$ numero após a letra refere-se ao ${ }^{1} \mathrm{H}$ respectivo no anel glicosídico. Os espectros foram gravados em um espectrômetro Bruker $500 \mathrm{MHz}$ Avance III a $25^{\circ} \mathrm{C}$.

Conclui-se que as análises das frações solúveis e insolúveis de Auricularia auricula foram identificados os açúcares manose e glicose com a identificação do polissacarídeo beta-glucana $(1,6)$ (Tabela 5). Outras análises serão necessárias para identificar os outros monossacarídeos identificados na Tabela 4, bem como analisar se os polissacarídeos estão ligados ou não. Outras análises que corroboram com os resultados estão nos anexos 9.2 - 9.4.

Tabela 5. Análise estrutural das frações de Auricularia auricula e Ganoderma lucidum.

\begin{tabular}{|ccc|}
\hline Cogumelo & Fração & Estrutura \\
\hline \multirow{2}{*}{ Auricularia auricula } & Solúvel & $\begin{array}{c}\beta \text {-D-Glc } p \text { e } \\
\alpha \text {-D-Man } p 2,6\end{array}$ \\
\cline { 2 - 3 } & Insolúvel & $\begin{array}{c}\beta \text {-D-Glc } p \text { 6 e } \\
\alpha \text {-D-Man } p 2,6\end{array}$ \\
\hline \multirow{2}{*}{ Ganoderma lucidum } & Solúvel & Em fase de determinação \\
\cline { 2 - 3 } & Insolúvel & Em fase de determinação \\
\hline
\end{tabular}

* Os monossacarídeos galactose, fucose e xilose detectados nas primeiras análises não foram identificados na técnica de ressonância magnética nuclear. 


\section{DISCUSSÃO}

Os metabólitos de cogumelos, como os polissacarídeos, são capazes de estimular diferentes células do sistema imunológico. Os principais efeitos descritos para estas moléculas são a mitogenicidade (indutores de proliferação), estimulação de células tronco hematopoiéticas e a ativação de células imunológicas, tais como células $\mathrm{T}$ helper, B, macrófagos, células NK e células dendríticas (Lull et al., 2005).

A habilidade de extrair e isolar metabólitos de cogumelos é de suma importância para modular a resposta imune, uma vez que diversos estudos demonstraram diferenças nas propriedades imunomodulatórias, dependendo do método utilizado. Uma molécula oriunda de G. lucidum ativou células B murinas e macrófagos, porém não foi capaz de ativar células T (Shao et al., 2004), mas polissacarídeos de Phellinus linteus ativaram macrófagos e células B e T (Kim et al. 1996). Contudo, Lentinana (oriundo de Lentinula edodes) é um estimulador de células T, porém não ativa células B (Liu et al., 1998).

Assim, extratos ou metabólitos provenientes de cogumelos devem ser selecionados e usados adequadamente para a modulação da resposta, avaliando a origem, estrutura e a atividade imunomodulatória (Zhu et al., 2003; Lull et al. 2005). Uma maneira de assegurar extratos com atividade biológica é a cultura por cultivo submerso. Este processo apresenta vantagens potenciais na produção micelial em um espaço compacto, tempo de incubação curto e da diminuição de uma potencial contaminação. A otimização da composição do meio de cultura e das condições físico-químicas de crescimento podem proporcionar uma regulação, bem como homogeinização da composição metabólica fúngica, bem como na obtenção de amostras substancialmente padronizadas e puras (Lull et al., 2005).

Uma vez padronizada, a produção dos polissacarídeos secretados (exopolissacarídeos) precisa ser caracterizada e quantificada, uma vez que a sua composição reflete a metodologia utilizada para sua obtenção independentemente da composição da parede celular e do exsudato extracelular do micro-organismo de origem (Donot et al., 2012; Osinska-Jaroszuk et al. 2015). As frações estudadas neste trabalho foram analisadas inicialmente pela de quantificação e composição monossacarídica, cujo resultado indicou a presença do monômero de glicose, o constituinte do polissacarídeo 
beta-glucana. Este resultado sugere que a utilização da técnica de cultivo submerso para obtenção de carboidratos biologicamente ativos foi bem-sucedida.

Recentemente, vários fungos filamentosos e leveduras foram considerados capazes de produzir EPS, como A. auricula cuja produção foi de até 7.5 gramas por litro (g/L) (Wu et al., 2006) e G. lucidum com até 4,8 g/L (Fraga et al. 2014). Neste trabalho as concentrações dos polissacararídeos foram menores, devido ao protocolo de produção ter sido adaptado para ser realizado em escala laboratorial.

O tempo de produção e obtenção dos EPS neste trabalho ocorreu entre treze a quartorze dias de cultivo. Entretanto, Wan-Mohtar e et al. (2016) reduziram o tempo de produção de EPS de G. lucidum de treze para seis dias, aperfeiçoando o processo e favorecendo a produção em larga escala. Contudo, esta técnica não foi avaliada neste trabalho.

A análise monossacarídica é uma etapa essencial para indicar o perfil da composição dos monossacarídeos de carboidratos complexos estudados. Os principais monossacarídeos produzidos foram a fucose, xilose, manose, galactose e glicose, sendo que nas frações solúveis os mais abundantes foram a fucose, manose, galactose e glicose e nas frações insolúveis foram os monossacarídeos glicose e manose, principalmente (Tabela 4).

O cultivo e a extração do corpo frutífero de A. auricula por Kadnikova et al. (2015) produziu os mesmos monossacarídeos descritos neste trabalho, com exceção da fucose. Contudo, Zhang et al. (2011) identificaram também a ramnose e arabinose. A composição dos monossacarídeos secretados pelo corpo frutífero de G. lucidum foi similar à descrita por Peng et al. (2015), exceto para os polímeros de ramnose, arabinose e ribose. A glicose foi sempre o monossacarídeo mais abundante obtido (Peng et al., 2015; Su et al., 2016).

Apesar de todas as frações apresentarem os mesmos monossacarídeos, a porcentagem entre elas foi distinta. O conjunto dos monossacarídeos secretados por cogumelos distintos está diretamente relacionado com os efeitos terapêuticos mostrando que o conjunto destes açúcares está associado a distintas atividades biológicas (Soltani et al., 2013; revisado de Bitencourt, 2015). 
Devido a características estruturais distintas, frações solúveis e insolúveis de betaglucanas apresentam diferentes aplicações, modos de ação e atividade biológica em geral. As duas frações, solúvel e insolúvel, demonstraram papéis importantes em várias funções do corpo humano e em doenças relacionadas a distúrbios imunológicos, como o aumento da quimiotaxia e adesão dos neutrófilos e o sinergismo nos fatores de crescimento mielóide, para aumentar a hematopoiese e mobilizar células progenitoras do sangue periférico in vivo. Ademais, estimularam diretamente células progenitoras do sangue periférico comprometidas, aumentaram a sobrevivência e regeneração hematopoiética em camundongos irradiados, amplificaram a taxa de fagocitose de células tumorais e a atividade antitumoral por meio de anticorpos monoclonais (Ali, 2009). A variação do tamanho, das estruturas e da composição de diferentes fontes de beta-glucanas ou de fungos patogênicos, que consequentemente pode ter um impacto sobre o envolvimento do receptor e da sinalização, além de determinar o tipo de resposta imunológica subsequente (Underhill e Goodridge, 2012).

As análises da estrutura de G. lucidum estão em fase de andamento e serão finalizadas, bem como novas avaliações serão realizadas para determinar os outros constituintes monossacarídicos detectados em ambas as frações insolúveis dos cogumelos quanto a estrutura (podendo haver uma única molécula constituída por mais de um tipo de açúcar) bem como avaliar outras possíveis atividades biológicas que foram descritas anteriormente na literatura.

Assim, conclui-se que pela da técnica de cultivo submerso utilizado no presente trabalho foi possível a obtenção da secreção de polissacarídeos, dentre eles a betaglucanas tanto por G. lucidum quanto por A. auricula. 
PARTE 2. A atividade imunomodulatória dos polissacarídeos provenientes de Auricularia auricula e Ganoderma lucidum estimularam a secreção de citocinas pró e anti-inflamatória pela ativação dos receptores dectina-1 e TLR2 por via canônica in vitro.

Neste capítulo foram avaliados atividade das frações de A. auricula e G. lucidum para (1) estimular a produção de citocinas pró-inflamatória (TNF- $\alpha$ ) e anti-inflamatória (IL-10) em células dendríticas, macrófagos M1 e M2; (2) induzir a citotoxicidade celular; e (3) mecanismos de ativação das células do sistema imunológico;

\section{MATERIAIS E MÉTODOS}

\section{Obtenção e cultivo de células imunes in vitro}

As células murinas foram obtidas de camundongos C57BL/6, em idade adulta, acondicionados no biotério do Instituto de Biologia da Universidade de Brasília - UnB, sob condições apropriadas e fornecimento de água e ração ad libitum.

Células derivadas de medula óssea foram coletadas do interior da tíbia e fêmur de camundongos, por meio de lavado femoral. Posteriormente às análises de viabilidade (utilizando azul de tripan) e concentração, as células foram cultivadas de acordo com o fenótipo desejado, em placas de petri (Prolab) contendo meio Roswell Park Memorial Institute (RPMI) 1640 (Sigma, ref. R4130), 0,2\% de bicarbonato de sódio (Sigma, ref. S6014), 25 miligramas por mililitro $(\mathrm{mg} / \mathrm{mL})$ de gentamicina (Gibco), filtrado usando filtro estéril (0,22 micrometros, Kasvi ref. K16-1250). Para obtenção de células dendríticas (DC) ("bone marrow derived dendritic cells" - BMDC) e macrófagos classicamente ativados ("bone marrow derived macrophages” - BMDM - M1) utilizouse um protocolo baseado nos trabalhos de Lutz (1999) e Lutz (2000). Para macrófagos ativados alternativamente (BMDM - M2) utilizou-se o protocolo de Kim e et al. (2015), com adaptações. Todos os ensaios de cultivo de células murinas in vitro foram realizados 
em triplicata biológica e repetido por três vezes, bem como todos os procedimentos utilizando os animais foram aprovados pelo comitê de ética da Universidade de Brasília (UnBDoc no. 66729/2016) (Anexo 9.5).

\section{Ensaio de produção de citocinas}

As células dendríticas e macrófagos (M1 e M2) foram cultivadas em meio RPMI estéril (nas mesmas condições descritas anteriormente) em placa de 96 poços, sob estímulo de frações solúveis e insolúveis durante 24 horas, a $37^{\circ} \mathrm{C}, 5 \%$ de dióxido de carbono $\left(\mathrm{CO}_{2}\right)$. Como controle positivo dos experimentos foi utilizado zimosan depletado (Invivogen, ref. 58856-93-2). Em seguida o sobrenadante foi coletado para dosagem de TNF- $\alpha$ e IL-10 através da técnica ELISA (Enzyme-Linked Immunosorbent Assay), usando o kit de TNF- $\alpha$ e Mouse IL-10 ELISA Ready-SET-Go! ®, de acordo com as instruções do fabricante.

\section{Ensaio de citotoxicidade}

A avaliação da citotoxicidade dos polissacarídeos foi realizada pela dosagem de lactato desidrogenase (LDH) e iodeto de propídeo (PI) (Invitrogen, ref. P3566). Para o ensaio de LDH, utilizou-se o kit CytoTox 96 Non-Radioactive Cytotoxicity Assay ( (Promega, ref. G1780), de acordo com as instruções do fabricante. Resumidamente, as células foram cultivadas em meio RPMI estéril $(0,2 \%$ de bicarbonato de sódio e 25 $\mathrm{mg} / \mathrm{mL}$ de gentamicina) em placa de 96 poços, sob estímulo de frações solúveis e insolúveis durante 12,24 e 48 horas, à $37^{\circ} \mathrm{C}, 5 \% \mathrm{CO}_{2}$. Após a coleta do sobrenadante, as amostras foram analisadas por espectrofotometria, em um comprimento de onda de 490 nm. O ensaio de iodeto de propídeo (PI) foi realizado utilizando a técnica de citometria de fluxo, baseando-se em Coelho et al. 2015. Resumidamente, $5 \times 10^{4}$ células foram incubadas em placa de cultura de células de 6 poços (Kasvi) à $37^{\circ} \mathrm{C}, 5 \% \mathrm{CO}_{2} \mathrm{e}$ estimuladas nas concentrações e períodos indicados nas figuras. Em seguida, as células foram desaderidas utilizando o tampão TrypLE (Invitrogen, ref. 12604013), lavadas com 
Phospahte Buffered Saline - PBS (137 milimolar - mM de NaCl, 2,7 mM KCl, 8,1 mM $\mathrm{Na}_{2} \mathrm{HPO}_{4}, 1,5 \mathrm{mM} \mathrm{KH} \mathrm{PO}_{4}, \mathrm{pH}$ 7.2-7.4) $1 \mathrm{X}$, e centrifugadas a $300 \mathrm{x}$ g, por 5 minutos. $\mathrm{O}$ sobrenadante foi descartado e as células foram ressuspendidas em PBS e $2 \%$ de soro fetal bovino. Em seguida, as células foram marcadas com PI (10 microgramas por mililitro $\mu \mathrm{g} / \mathrm{mL}$ ) durante 5 minutos. Para o controle positivo de PI utilizou-se etanol $70 \%$, por 5 a 10 minutos.

\section{Ensaio da possível presença de LPS na atividade biológica dos cogumelos}

Para avaliar a possível presença de lipídeos e interferência na atividade dos polissacarídeos, foi utilizada o protocolo número 5 de Varelas et al., 2015. De forma resumida, foi adicionado isopropanol na proporção de 1:4 às amostras e aquecidas sob refluxo por 2 horas. Em seguida as amostras foram centrifugadas à 5000 x g por 10 minutos. O sobrenadante foi descartado e o precipitado foi lavado três vezes com acetona (proporção 1:1). Em seguida o precipitado foi seco, ressuspendido e utilizado para análise.

As frações insolúveis $(100 \mu \mathrm{g} / \mathrm{mL})$ e/ou lipopolisacarídeo (LPS, 500 nanogramas por mililitro, $\mathrm{ng} / \mathrm{mL}$ ) (Invivogen) foram incubados com macrófagos M1 ou células dendríticas em meio de cultura RPMI estéril (nas mesmas condições descritas anteriormente) tratados previamente com polimixina B (30 microgramas por mililitro $\mu \mathrm{g} / \mathrm{mL}$, ref. Gibco, 21850-029) (concentração de $5 \times 10^{4}$ por poço) durante 24 horas, à $37^{\circ} \mathrm{C}, 5 \% \mathrm{CO}_{2}$. Após este período o sobrenadante foi coletado para dosagem de TNF- $\alpha$ pela técnica de ELISA como descrito anteriormente.

\section{Ensaio da importância da internalização das frações na capacidade de estimular a secreção de TNF- $\alpha$}

Para avaliar a importância da fagocitose na sinalização intracelular após a incubação das células com as frações, utilizou-se o bloqueador de fagocitose citocalasina D (Sigma, ref. C8273). As células foram cultivadas em placa de 96 poços, em meio de 
cultura RPMI (nas mesmas condições descritas anteriormente) contendo citocalasina D, nas concentrações de 1,2 e 4 micromolar $(\mu \mathrm{M})$ durante 1 hora, a $37^{\circ} \mathrm{C}, 5 \% \mathrm{CO}_{2}$. Em seguida, após a troca de meio de cultura, adicionaram-se as frações insolúveis de polissacarídeos, durante 24 horas. O sobrenadante foi coletado para dosagem de TNF- $\alpha$ pela técnica de ELISA como descrito anteriormente.

\section{Ensaio de determinação dos receptores de reconhecimento padrão e da sinalização intracelular induzida pelas frações avaliadas}

Os camundongos utilizados para os experimentos de receptores ineficientes foram nocautes de TLR2, TLR4, dectina-1, 2 e 3. Os animais TLR2 e TLR4 KO foram cedidos pelo Prof. Dr. João Santana da Silva, da USP/Ribeirão Preto. Os animais dectina-1 foram cedidos pelo Prof. Dr. Gordon Brown da universidade de Alberdeen, Reino Unido e os animais dectina-2 e dectina-3 foram cedidos pelo Prof. Dr. Bruce Klein, Universidade de Wisconsin (Estados Unidos). As células destes animais foram extraídas da tíbia e fêmur e cultivadas utilizando protocolo mencionado anteriormente. Brevemente, as células dendríticas ou macrófagos (M1) nocautes ou selvagens foram cultivadas em meio RPMI estéril (nas mesmas condições descritas anteriormente) em placa de 96 poços, sob estímulo de frações solúveis e insolúveis durante 24 horas, a $37^{\circ} \mathrm{C}, 5 \% \mathrm{CO}_{2}$. Em seguida o sobrenadante foi coletado para dosagem de TNF- $\alpha$ pela técnica de ELISA como descrito no item 2.1.3.

A ligação dos polissacarídeos a alguns receptores da família dos CLRs também foi avaliada, utilizando linfócitos $\mathrm{T}$ transgênicos que expressavam o receptor FC gama (FcR $\gamma$ ), dectina-1, dectina-2, Mincle (macrophage inducible C-type lectin) e MCL (macrophage C-type lectin) (dectina-3). O gene repórter GFP foi inserido na sequencia genômica das células, para indicar a ativação e interação ligante-receptor. Após 18 horas de incubação, as amostras foram lidas em comprimento de onda de $560 \mathrm{~nm}$. O experimento foi baseado em Wüthrich et al. (2015) e realizado no laboratório do Dr. Bruce Klein, Universidade de Wisconsin (EUA), com o auxílio do Dr. Isaque Medeiros.

A interação dos receptores de células dendríticas e macrófagos M1 com as frações de cogumelos foi avaliada por meio do cultivo das células em meio RPMI estéril (nas 
mesmas condições descritas anteriormente) em placa de 96 poços, sob estímulo de frações solúveis e insolúveis durante 24 horas, a $37^{\circ} \mathrm{C}, 5 \% \mathrm{CO}_{2}$. Em seguida o sobrenadante foi coletado para dosagem de TNF- $\alpha$ pela técnica de ELISA como descrito anteriormente.

Para a avaliação da participação das vias de sinalização de Syk (Spleen tyrosine kinase) ou Raf-1 (serine/threonine-protein kinase) após os estímulos com as frações, células dendríticas foram incubadas em meio RPMI estéril (nas mesmas condições descritas anteriormente) na presença ou não dos inibidores R406 (5 $\mu \mathrm{M}$, Invivogen) e Raf1 Kinase (9 mM, ref. 553008, Calbiochem) que são bloqueadores de Syk e Raf-1, respectivamente, e celatrol ( $5 \mu \mathrm{M}$, Invivogen), inibidor do fator de transcrição NF-kB (factor nuclear kappa B). Após 1 hora de incubação com os inibidores, as células foram incubadas com as frações insolúveis de A. auricula e G. lucidum durante 24 horas. Após este período, o sobrenadante foi coletado para dosagem de TNF- $\alpha$ pela técnica de ELISA como descrito no anteriormente.

\section{Ensaio da capacidade das frações em estimular a expressão de marcadores de ativação das células dendríticas}

A determinação da modulação da ativação das células dendríticas foi realizada pela quantificação dos receptores CD80, CD86 e do complexo principal de histocompatibilidade de classe II (MHC-II) após estímulo com os polissacarídeos, por citometria de fluxo. Células dendríticas (na concentração de $3 \times 10^{6}$, placa de seis poços) foram cultivadas em meio RPMI estéril (nas mesmas condições descritas anteriormente) e estimuladas com a fração insolúvel por 12 horas, a $37^{\circ} \mathrm{C}, 5 \% \mathrm{CO}_{2}$. Após este período as células foram desaderidas, lavadas com PBS $1 \mathrm{X}$ uma vez ( $300 \mathrm{x} \mathrm{g}, 5$ minutos, $\left.4^{\circ} \mathrm{C}\right)$, e marcadas com os anticorpos anti-CD11c (APC, eBioscience), isotipo controle IgG1 (APC, Ebioscience), anti-CD80 (FITC, eBioscience), anti-CD86 (FITC, eBioscience) e anti-MHC-II (FITC, eBioscience) de acordo com as instruções do fabricante. Posteriormente, as células marcadas foram lavadas três vezes com PBS contendo $2 \%$ de soro fetal bovino e ressuspendidas no mesmo tampão de lavagem para análise. Para a estratégia de seleção de células positivas foram (1) selecionadas populações de células de acordo com tamanho e granulosidade para o tipo celular (BMDC) (SSC-A vs FSC-A), 
(2) excluídos os doublets (grumos de células) (FSC-A vs FSC-W) e (3) selecionadas células positivas para o marcador de identificação CD11c (Anexo 9.6).

\section{Análise estatística}

Todos os resultados desta parte do trabalho foram analisados com desvio padrão da média (SEM) da triplicata biológica feita de um dos experimentos independentes, de um total de três análises técnicas. Para avaliar estatisticamente diferenças entre grupos experimentais a análise da variância (ANOVA), seguida pelos métodos Sidak, Turkey e Dunnett's foram utilizados pelo software GraphPad Prism (versão 6.0). Os dados foram considerados significantes quando $\mathrm{p}<0,05$.

\section{RESULTADOS}

Avaliação de citotoxicidade de polissacarídeos de Auricularia auricula e Ganoderma lucidum.

A molécula LDH é uma enzima citosólica, cuja detecção no fluido extracelular indica morte ou perda da integridade celular, um importante marcador da viabilidade celular (Lucisano e Mantovani, 1984; revisado de Monteiro, 2015). Para avaliar possíveis efeitos citotóxicos dos polissacarídeos obtidos em células inatas, a dosagem de LDH foi feita do cultivo celular de macrófagos (M1 e M2) e células dendríticas estimulados com as frações obtidas da Auricularia auricula e Ganoderma lucidum (Figura 18).

Os resultados indicaram que de todas as frações avaliadas em células dendríticas e macrófagos M1, a fração solúvel de A. auricula causou redução total da viabilidade celular entre os tempos de 12 a 48 horas, o que não era esperado. Entretanto, para a fração solúvel de G. lucidum e as frações insolúveis de ambos os cogumelos, não houve ação citotóxica dos compostos. Para os macrófagos M2, a fração solúvel de G. lucidum não 
alterou a viabilidade celular. No caso de A. auricula, a fração solúvel também apresentou uma redução da viabilidade, que variou entre (60 a 80\%); porém em porcentagem maior quando comparado à de células dendríticas e macrófagos M1 (0\%). Ademais, para as frações insolúveis de G. lucidum $(200 \mu \mathrm{g} / \mathrm{mL})$ a viabilidade foi também reduzida, permanecendo entre 5 a $40 \%$ e de A. auricula permaneceu aproximadamente em $80 \%$. Desta forma, demonstra-se um uma atividade distinta das frações, induzindo um perfil de viabilidade celular diferente entre células dendrítica, M1 e M2 (Figura 16).
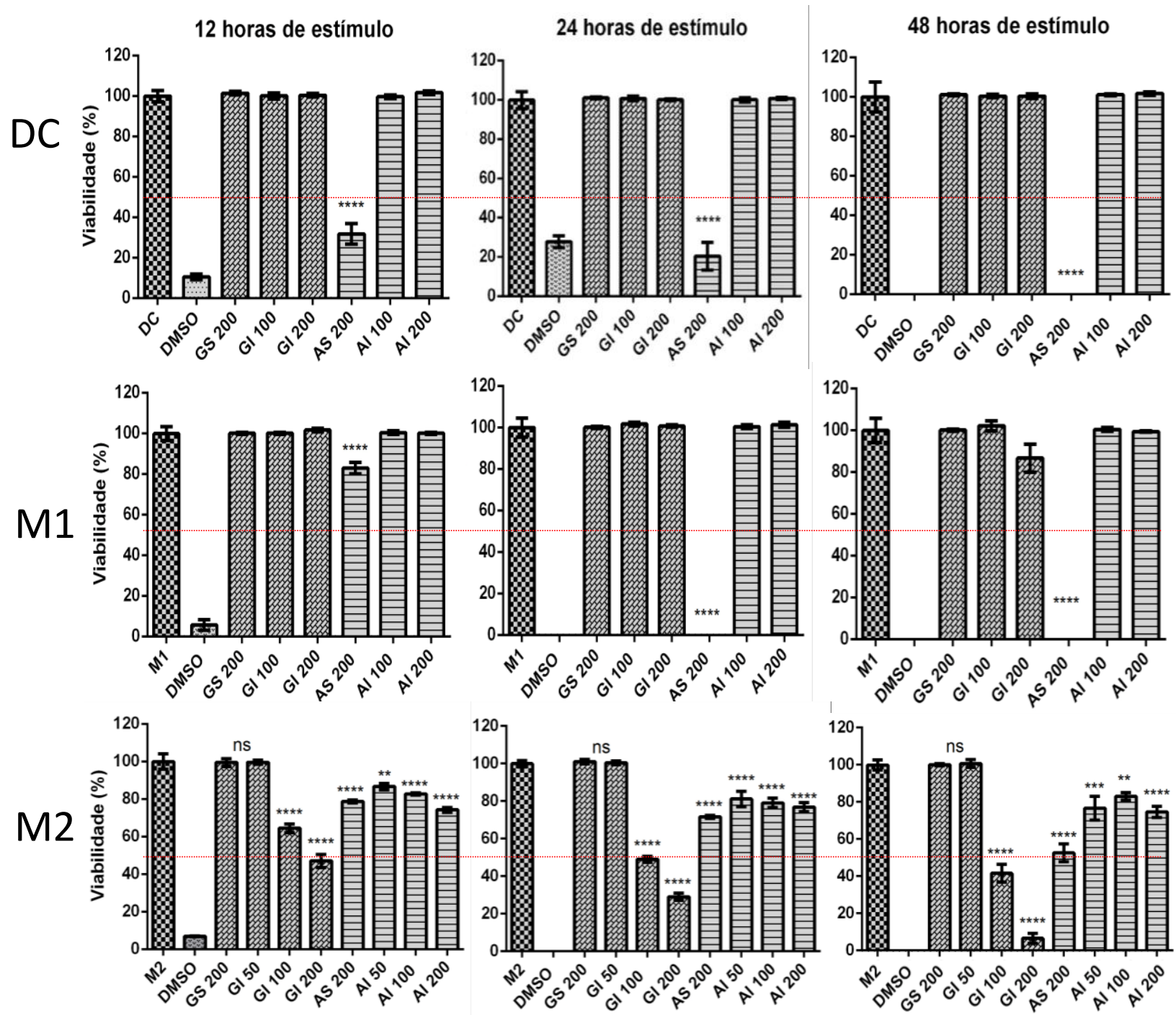

Figura 16. Viabilidade celular após estímulos com polissacarídeos de A. aurícula e G. lucidum. Os tempos avaliados foram de 12, 24 e 48 horas após estímulos. GS 200 - Ganoderma lucidum fração solúvel $200 \mu \mathrm{g} / \mathrm{mL}$; GI 50, 100 e GI 200 - Ganoderma lucidum fração insolúvel 50, 100 e $200 \mu \mathrm{g} / \mathrm{mL}$, respectivamente; AS 200 - Auricularia auricula fração solúvel $200 \mu \mathrm{g} / \mathrm{mL}$; AI 50, 100 e AI 200 Auricularia auricula fração insolúvel 50,100 e $200 \mu \mathrm{g} / \mathrm{mL}$, respectivamente; DC - Células Dendríticas; M1 - Macrófagos classicamente ativados; M2 Macrófagos alternativamente ativados; controle positivo, DMSO (dimetilsulfóxido) $15 \%$, controle negativo - célula não tratada; Linha vermelha pontilhada indica o 
limite mínimo de viabilidade celular aceitável. Experimento repetido em triplicata biológica. $\mathrm{p}$ significante $<0,05$.

A figura 16 mostra a viabilidade celular utilizando o iodeto de propídeo, pela de citometria de fluxo. O iodeto de propídio foi utilizado, sendo um corante que intercala nas bases nitrogenadas do DNA de células não viáveis, produzindo consequentemente emissão de fluorescência. Uma vez que a célula é estável, o corante não é capaz de atravessar a membrana plasmática em direção ao núcleo (Ormerod et al., 1992; revisado de Raele, 2013). Assim, para confirmar os resultados obtidos pela análise de LDH, o corante iodeto de propídeo foi adicionado às células nos tempos de 12, 24 e 48 horas após estímulos com os polissacarídeos (figura 17).
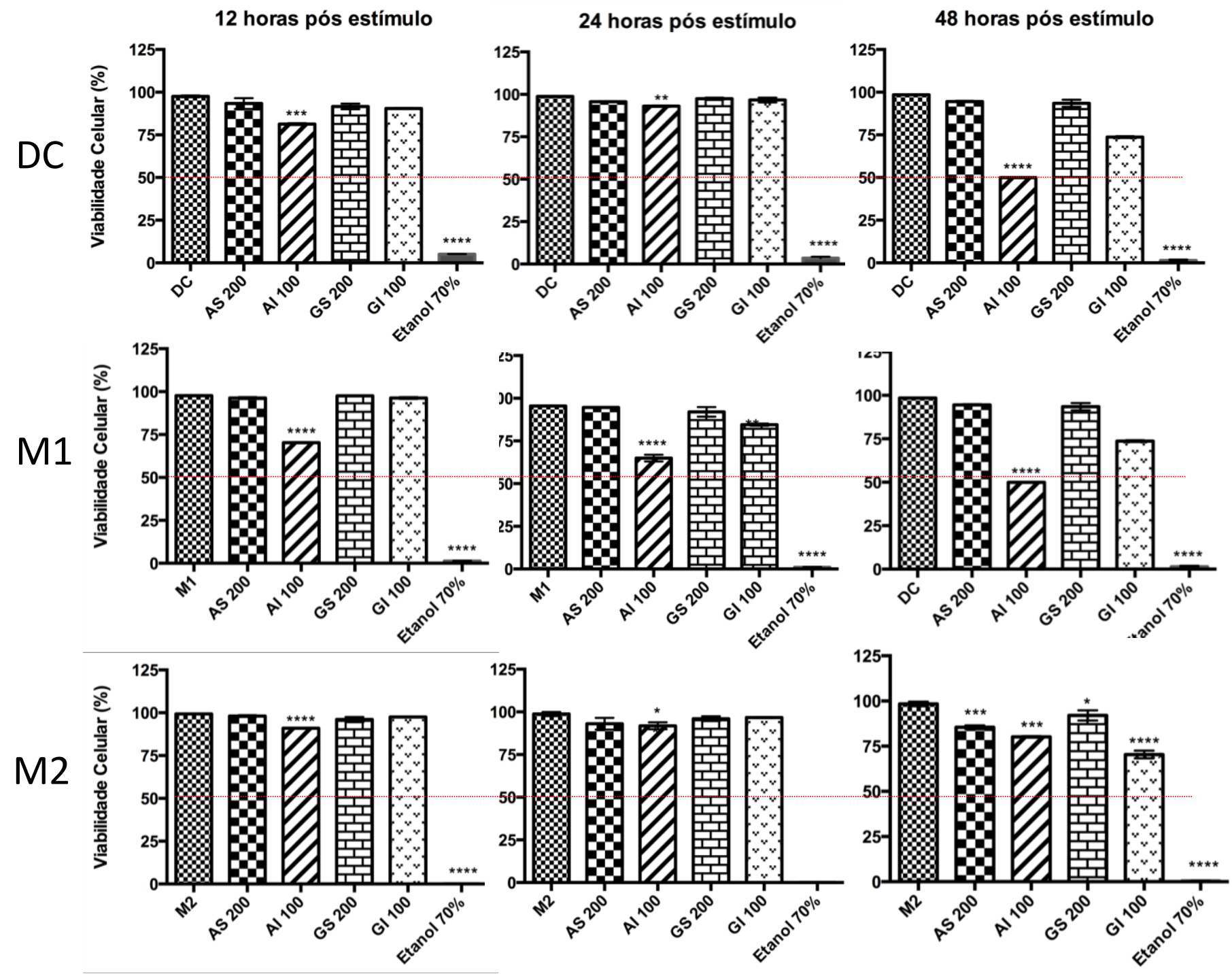

Figura 17. Viabilidade celular após estímulos com polissacarídeos de $A$. aurícula e G. lucidum avaliado por citometria de fluxo. Os tempos avaliados foram de 12, 24 e 48 horas após estímulos. GS 200 - Ganoderma lucidum fração solúvel $200 \mu \mathrm{g} / \mathrm{mL}$; GI 100 - Ganoderma lucidum fração insolúvel 100 $\mu \mathrm{g} / \mathrm{mL}$; AS 200 - Auricularia auricula fração solúvel $200 \mu \mathrm{g} / \mathrm{mL}$; AI 100 - Auricularia auricula fração insolúvel $100 \mu \mathrm{g} / \mathrm{mL}$; DC - Células Dendríticas; M1 - Macrófagos classicamente ativados; M2 Macrófagos alternativamente ativados; controle positivo - Etanol 70\%, controle negativo - célula não tratada; Linha 
vermelha pontilhada indica o limite mínimo de viabilidade celular aceitável. Experimento repetido em triplicata biológica. $\mathrm{p}$ significante quando $<0,05$.

A figura 16 corrobora com o resultado da figura anterior, cuja viabilidade celular de uma forma geral foi considerada aceitável em todos os tempos avaliados, exceto na fração AS $200 \mu \mathrm{g} / \mathrm{mL}$. Além disso, a figura 17 demonstra que a fração solúvel de Auricularia auricula e a fração insolúvel de Ganoderma lucidum não apresentaram porcentagem baixa de viabilidade celular.

\section{Avaliação da produção de citocinas induzida pelos polissacarídeos de Auricularia auricula e Ganoderma lucidum.}

A medicina moderna utiliza com sucesso imunomoduladores de origem natural, que interferem em reações biológicas e proporcionam mecanismos de defesa ao hospedeiro (Piotrowski et al., 2015). As frações solúveis e insolúveis de A. auricula e $G$. lucidum foram avaliadas quanto à capacidade de estimular a produção de citocinas pró (TNF- $\alpha$ ) e anti-inflamatória (IL-10) (Figura 18).
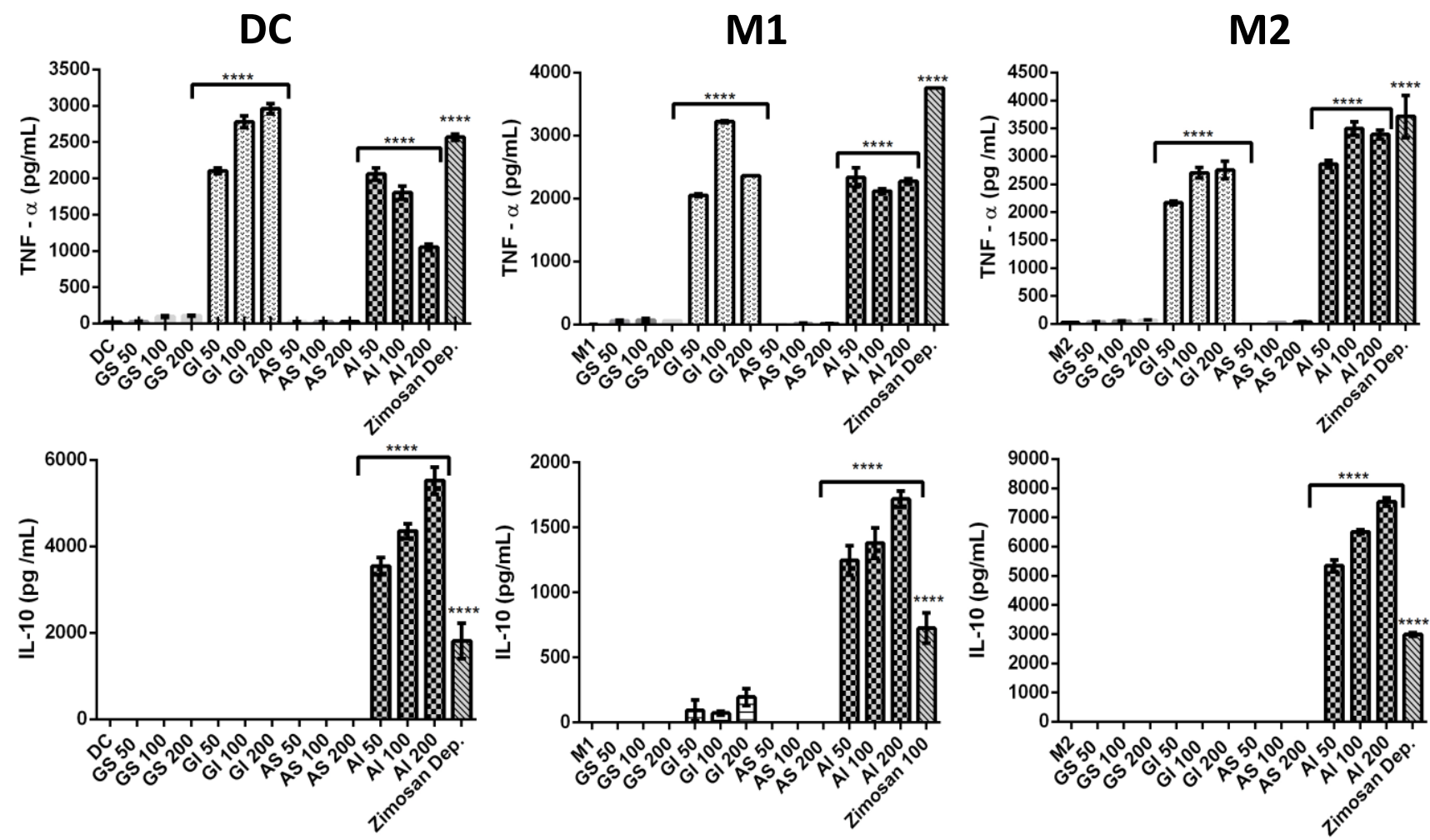

Figura 18. Produção de citocinas após estímulos com polissacarídeos de A. auricula e G. lucidum. Sobrenadante do cultivo celular avaliado após 24 horas de estímulo. GS - Ganoderma lucidum Solúvel, GI - Ganoderma lucidum Insolúvel; AS - Auricularia auricula Solúvel, AI - Auricularia auricula Insolúvel; concentrações de 50 a $200 \mu \mathrm{g} / \mathrm{mL}$ para todas as frações testadas. DC - Células Dendríticas; M1 Macrófagos classicamente ativados; M2 Macrófagos alternativamente ativados; Zimosan Dep. - Zimosan 
depletado, controle positivo; Análise estatística comparando controle (células não estimuladas) aos tratamentos. Experimento realizado em triplicata biológica. p significante quando $<0,05$.

De acordo com a figura 20, a produção de TNF- $\alpha$ foi observada somente nas frações insolúveis para todas as células avaliadas em um padrão dose não dependente. A avaliação da secreção de IL-10 indica produção de forma dose dependente entre células dendríticas, M1 e M2 somente para a frações insolúveis de A. auricula. Assim, somente as frações insolúveis de $A$. auricula estimularam a produção das duas citocinas avaliadas, enquanto a fração insolúvel de G. lucidum indicou atividade apenas para a produção de TNF- $\alpha$. Após o resultado da figura 18, apenas as frações insolúveis dos cogumelos Auricularia auricula e Ganoderma lucidum serão avaliados em experimentos posteriores.

\section{Determinação da possível interferência de LPS presente nos compostos de Auricularia auricula e Ganoderma lucidum.}

A obtenção de compostos de fontes naturais por vezes encontra-se contaminada com LPS (Beutler, 2004). Os ácidos graxos participam de processos de sinalização intracelular, podendo modular funções do sistema imune (Parveen, 2003). Para avaliar uma possível interferência deste componente, frações que induziram a produção de citocinas foram tratadas para a remoção de lipídeos. Posteriormente, os polissacarídeos foram adicionados em cultura de células dendríticas e o perfil de TNF- $\alpha$ foi analisado (figura 19).

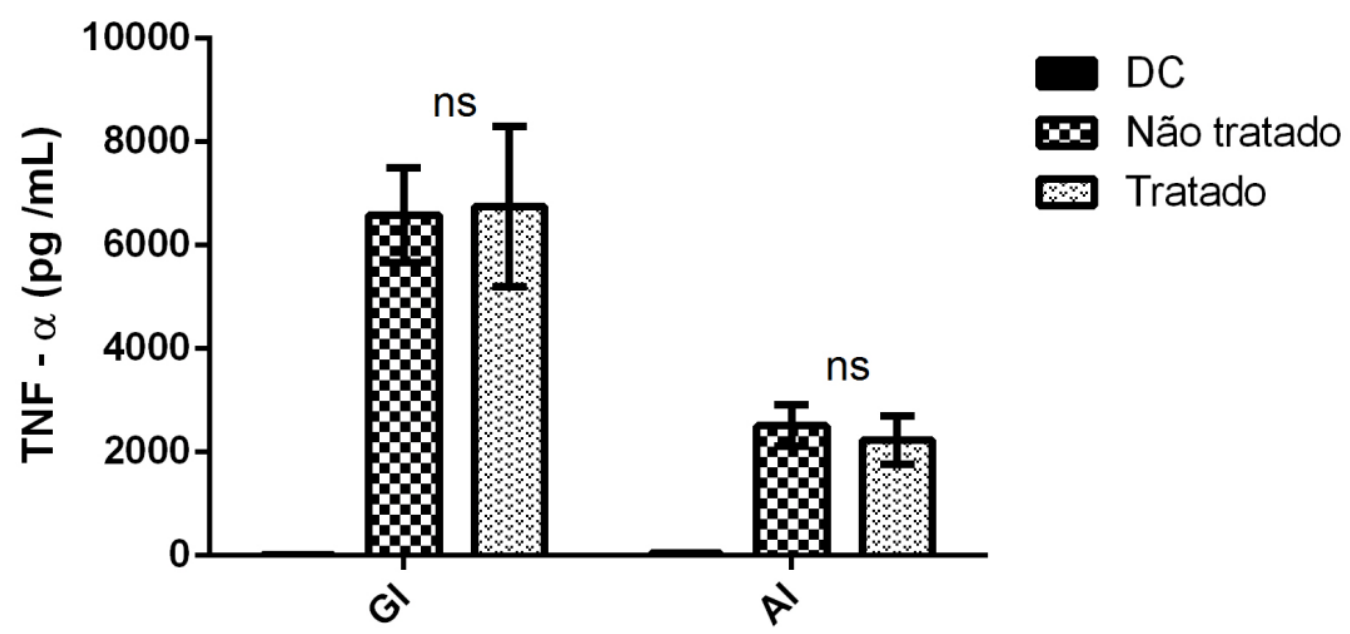

Figura 19. Células dendríticas estimuladas com as frações insolúveis dos polissacarídeos tratados e não tratados de A. auricula e G. lucidum. O tempo de estímulo dos polissacarídeos foi de 24 horas; GI Ganoderma lucidum fração insolúvel; AI - Auricularia auricula fração insolúvel; Concentração de 100 
$\mu \mathrm{g} / \mathrm{mL}$ para as amostras testadas; DC - células dendríticas; ns - não significante; Análise estatística comparando controles aos tratamentos. Experimento repetido em triplicata biológica. $\mathrm{p}$ significante quando $<0,05$.

O ensaio indicou que após tratamento das frações insolúveis para a remoção dos lipídeos inclusive o LPS, estas não apresentaram diferença na capacidade de estimular a produção de TNF- $\alpha$, indicando que não houve interferência de lipídeos nos estímulos e produção da citocina.

Para confirmar estes dados utilizamos a polimixina B, que é empregado para detectar indiretamente a presença de LPS e cuja função é se ligar a regiões do lipopolisacarídeo e neutralizá-lo (Kataoka et al., 2002). Os polissacarídeos obtidos dos macrofungos foram analisados quanto à presença do contaminante LPS (Figura 20).

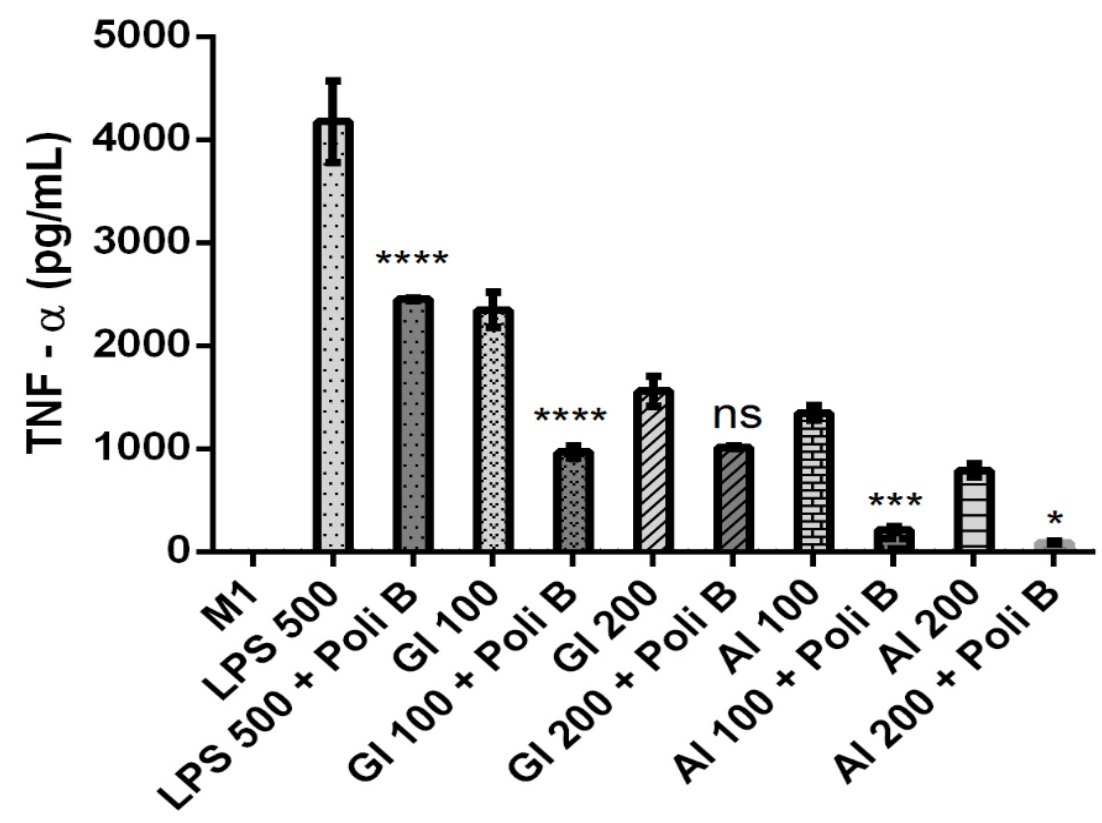

Figura 20. Ensaio de polimixina B para detecção de LPS nos compostos de polissacarídeos de $\boldsymbol{A}$. auricula e G. lucidum. O tempo de estímulo dos polissacarídeos foi de 24 horas; LPS 500 - LPS 500 ng/mL; GI 100 e 200 - Ganoderma lucidum fração insolúvel; AI 100 e 200 - Auricularia auricula fração insolúvel; Concentrações de 100 ou $200 \mu \mathrm{g} / \mathrm{mL}$ para as amostras testadas; M1 - Macrófagos classicamente ativados; ns - não significante; Análise estatística comparando controles aos tratamentos. Experimento repetido em triplicata biológica. p significante quando $<0,05$.

O resultado indica que as amostras de polissacarídeos obtidos podem estar contaminadas com LPS, principalmente baseando-se nas amostras não tratadas com o inibidor polimixina B (controle) (Figura 20). 
Para comprovar definitivamente a presença de LPS nas amostras, utilizou-se células deficientes para o receptor TLR4 estimulados com os compostos. A análise dos estímulos dos polissacarídeos de ambos os cogumelos em células deficientes para o receptor é apresentada na Figura 21.

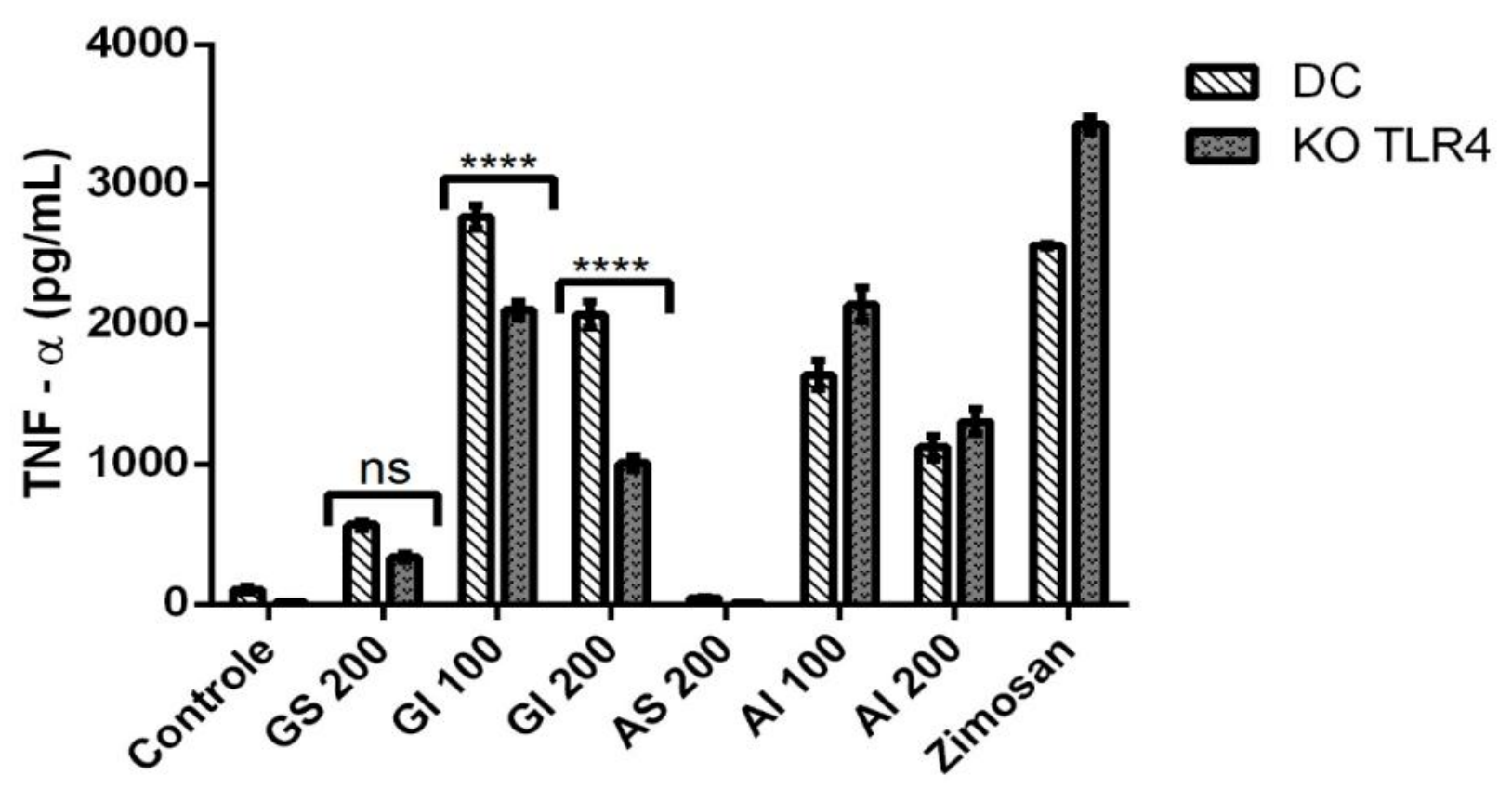

Figura 21. Estímulo de polissacarídeos de A. auricula e G. lucidum em células nocautes para TLR4. O tempo de estímulo dos polissacarídeos foi de 24 horas; GS - Ganoderma lucidum Solúvel, GI Ganoderma lucidum Insolúvel; AS - Auricularia auricula Solúvel, AI - Auricularia auricula Insolúvel; concentrações de 100 e $200 \mu \mathrm{g} / \mathrm{mL}$ para todas as frações testadas; Zimosan - Zimosan depletado 100 $\mu \mathrm{g} / \mathrm{mL}$; DC - Células Dendríticas; KO TLR4 - receptor TLR4 não funcional; ns - não significante. Experimento realizado em triplicata biológica. Análise estatística comparando controle aos tratamentos. $p$ significante quando $<0,05$.

Os estímulos de ambas as frações dos polissacarídicas de Auricularia auricula nas células deficientes para o receptor TLR4 não demonstraram diminuição dos níveis da citocina TNF- $\alpha$, mesmo resultado encontrado no controle (Zimosan depletado). Contudo, houve uma redução dos níveis da citocina após estímulo das frações de Ganoderma lucidum. De acordo com os resultados obtidos e apresentados, somente as frações insolúveis serão utilizadas para análises posteriores, exceto a figura 24.

Avaliação da atividade fagocítica para a sinalização intracelular. 
O processo de fagocitose envolve a internalização, gerando a ativação do fagócito, mas a ativação destas células não está diretamente relacionada com a internalização de partículas (Underhill e Goodridge, 2012). Para avaliar a necessidade da internalização e transdução do sinal intracelular nas células dendríticas e macrófagos (M1 e M2) estimulados com as frações insolúveis dos polissacarídeos, utilizou-se a citocalasina D que bloqueia a fagocitose e consequentemente diminui a produção do TNF- $\alpha$ (McCann et al., 2005; Vance et al., 2016) (Figura 22).

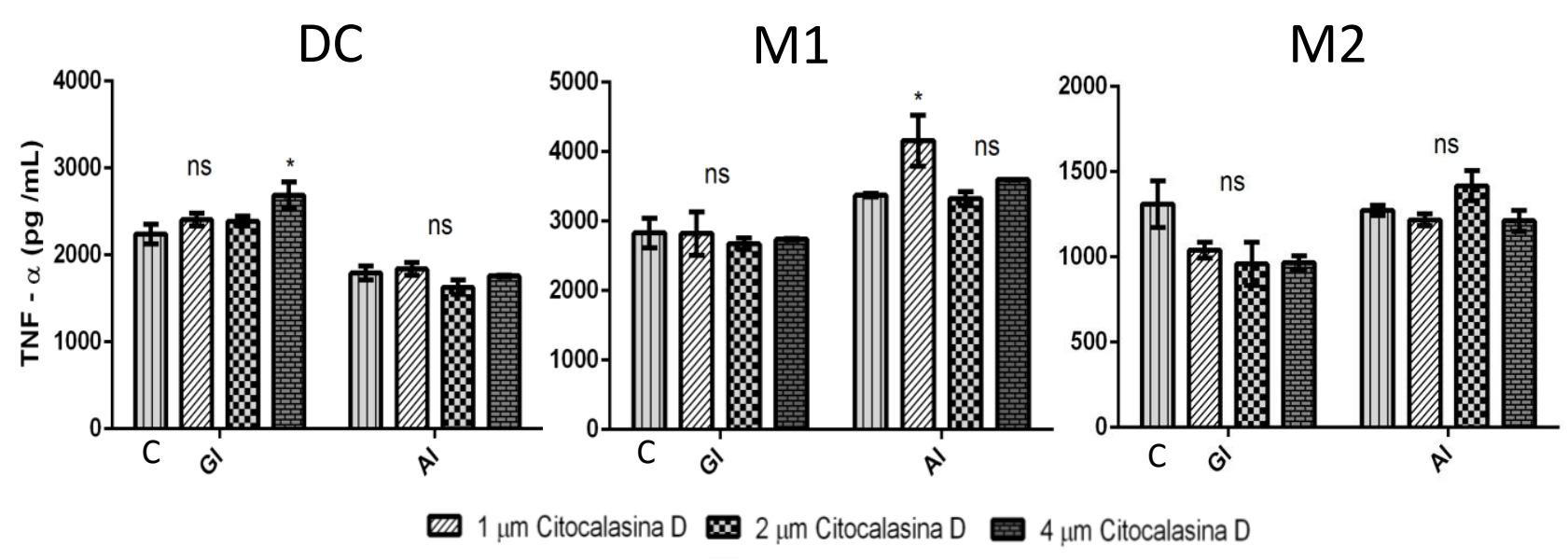

Figura 22. Produção de TNF- $\alpha$ no bloqueio da fagocitose em células estimuladas com polissacarídeos de A. auricula e G. lucidum. Sobrenadante do cultivo celular avaliado após 24 horas de estímulo.GI Ganoderma lucidum fração insolúvel, AI - Auricularia auricula fração insolúvel; Concentração de 100 $\mu \mathrm{g} / \mathrm{mL}$ para as amostras testadas; C - controle negativo, amostras não tratadas; DC - Células Dendríticas; M1 - Macrófagos classicamente ativados; M2 Macrófagos alternativamente ativados; ns - não significante, Análise estatística comparando células não tratadas (controle) aos tratamentos. Experimento realizado em triplicata biológica. $\mathrm{p}$ significante quando $<0,05$.

A figura 22 demonstrou que a produção da citocina TNF- $\alpha$ não requer a internalização das frações insolúveis de Auricularia auricula e Ganoderma lucidum, uma vez que os níveis permaneceram estatisticamente iguais após o tratamento com o inibidor citocalasina D.

Avaliação dos receptores e vias de sinalização de TLRs e CLRs sob estímulo dos polissacarídeos. 
O sistema imunológico, por meio de receptores, reconhece polissacarídeos nas frações solúveis e insolúveis de diversos fungos (Brown, 2006). Para avaliar os receptores envolvidos na sinalização dos polímeros de A. auricula e G. lucidum, a citocina TNF- $\alpha$ foi dosada no sobrenadante da cultura de células obtidas de animais geneticamente

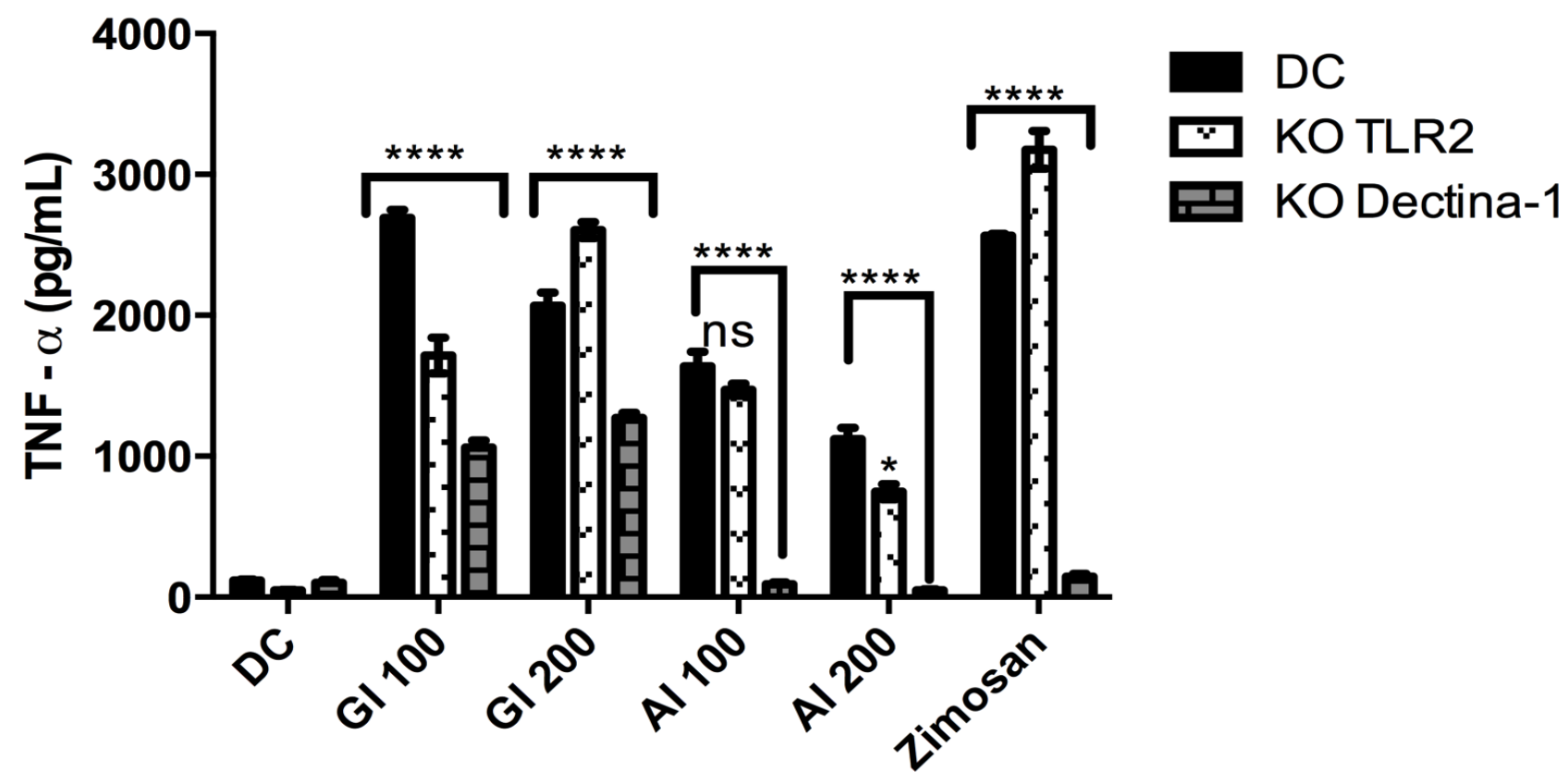

modificados (nocautes - KO) ou não (WT) para os receptores dectina-1 e TLR2. (Figura 23).

Figura 23. Estímulo de polissacarídeos de A. auricula e G. lucidum em células nocautes para dectina1 e TLR2. O tempo de estímulo dos polissacarídeos foi de 24 horas; GI - Ganoderma lucidum Insolúvel; AI - Auricularia auricula Insolúvel; concentrações de 100 e $200 \mu \mathrm{g} / \mathrm{mL}$ para todas as frações testadas; Controle - zimosan comercial livre de LPS e agonista do receptor dectina-1 - zimosan depletado, $100 \mu \mathrm{g} / \mathrm{m}$, L; DC - Células Dendríticas; KO TLR2 - receptor TLR2 não funcional; KO Dectina-1 - receptor dectina1 não funcional; ns - não significante; Análise estatística comparando controle aos tratamentos. Experimento realizado em triplicata biológica. p significante quando $<0,05$.

O estímulo dos polímeros de A. auricula resultou na abolição dos níveis de TNF$\alpha$ quando as células não apresentaram o receptor dectina-1 funcional, porém não houve o mesmo resultado na ausência funcional dos receptores TLR-2. As frações de G. lucidum, em ambas as concentrações testadas, diminuíram em aproximadamente 50\% dos níveis da citocina na ausência do receptor dectina-1.

Em relação ao receptor TLR2, a fração insolúvel de Ganoderma lucidum (concentração de $100 \mu \mathrm{g} / \mathrm{mL}$ ) estimulou níveis menores de TNF- $\alpha$ quando comparado a células selvagens, demonstrando a importância deste receptor para a produção da citocina 
avaliada. As frações de $200 \mu \mathrm{g} / \mathrm{mL}$ de ambos os cogumelos estimularam níveis de TNF$\alpha$ elevados (Ganoderma lucidum) ou diminuídos (Auricularia auricula) quando comparado ao controle. Após o resultado da figura 23, apenas as concentrações de 100 $\mu \mathrm{g} / \mathrm{mL}$ serão utilizadas para análises posteriores, uma vez que a concentração de 200 $\mu \mathrm{g} / \mathrm{mL}$ estimulou uma produção de TNF- $\alpha$ de maneira inespecífica.

As frações de parede celular contendo outros componentes além das betaglucanas, como é o caso de zimosan, podem interagir com os diversos receptores de reconhecimento padrão (PRRs), e apresentar uma importante atividade biológica in vitro (Brown et a., 2003). O polissacarídeo zimosan é capaz de ligar-se à diversos receptores, como o TLR-2, CR3 e a dectina-1, provocando uma ativação mediada por interações cruzadas entre vários receptores (Adams, et al., 1997; Battle et al., 1998, Williams et al., 2004, Brown et al., 2006). Ademais, o zimosan depletado é tratado quimicamente para interagir somente com a dectina-1. Observando os resultados apresentados anteriormente, é possível disser que a fração insolúvel da Auricularia auricula se liga especificamente à dectina-1 enquanto G. lucidum se liga tanto ao TLR-2 como a dectina-1.

Para confirmar a interação dos polissacarídeos obtidos de A. auricula e G. lucidum a outros receptores CLRs, em especial à dectina-1, utilizou-se um sistema repórter que identifica a interação de estimuladores a determinados receptores avaliados (Figura 24).

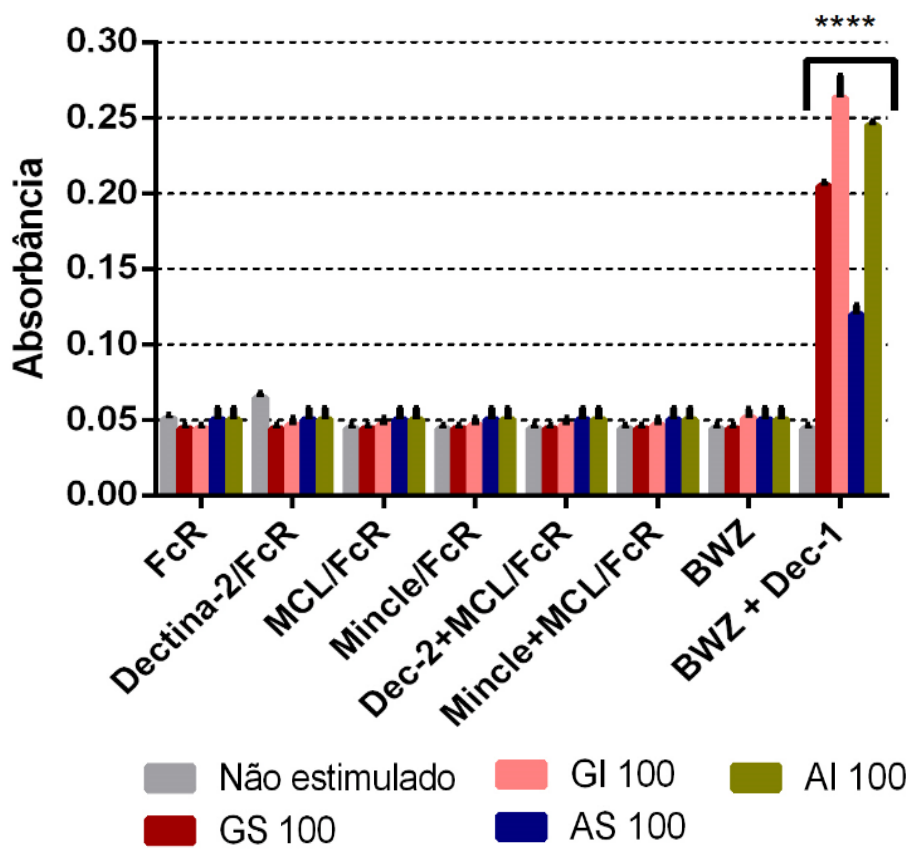

Figura 24. Ensaio repórter da interação de receptores CLRs e os polissacarídeos de A. auricula e G. lucidum. Células BWZ transgênica e sublinhagens expressando dectina-1, células B3Z expressando dectina-2, Mincle, a cadeia FcR $\gamma$, dectina-2 $+\mathrm{FcR} \gamma, \mathrm{MCL}$ (dectina-3) + FcR $\gamma$, dectina$2+\mathrm{MCL}+\mathrm{FcR} \gamma$, Mincle + FcR $\gamma$ ou Mincle $+\mathrm{MCL}+\mathrm{FcR} \gamma$ foram estimuladas com polissacarídeos por 18 horas. Após esse período, a atividade de lacZ foi mensurada em ensaio colorimétrico sob OD 560/620. GS - Ganoderma solúvel; GI - Ganoderma Insolúvel; AS - Auricularia auricula solúvel; AI - Auricularia auricula Insolúvel; Concentração de $100 \mu \mathrm{g} / \mathrm{mL}$ para todas as frações testadas. Experimento realizado em triplicata biológica. $\mathrm{p}$ significante quando $<0,05$. 
No modelo de estudo, avaliando a ativação individual ou conjunta de receptores CLRs, foi analisado se as frações de ambos os cogumelos se ligam apenas ao receptor dectina-1. As frações foram incubadas com células de animais geneticamente modificados para dectina-2 e dectina-3 e, a dosagem de TNF- $\alpha$ foi realizada (Figuras 25 e 26).

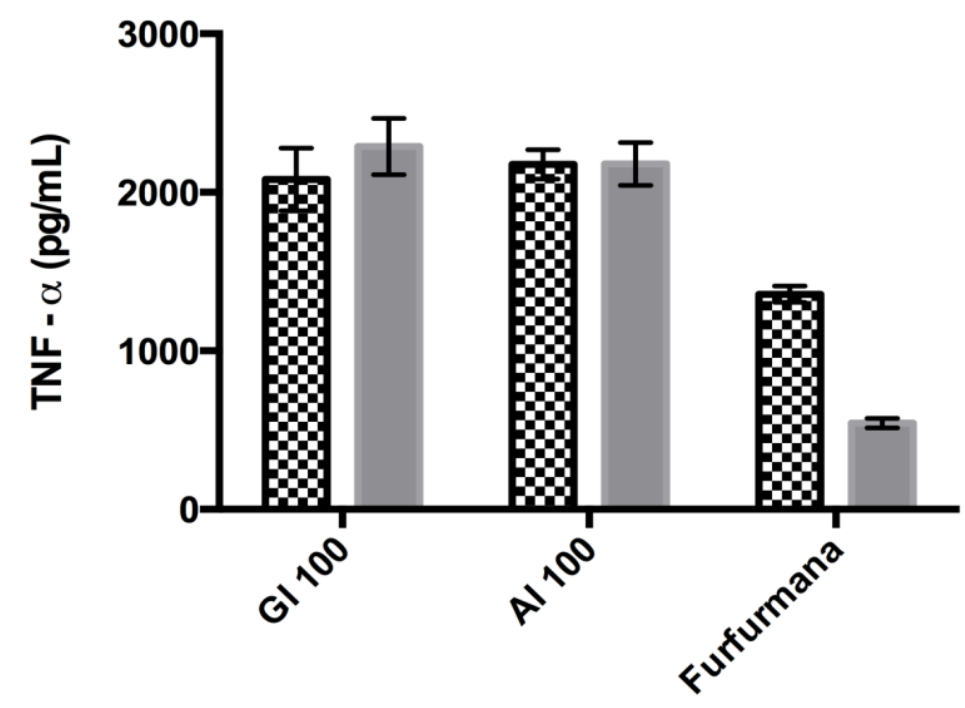

Deg DC

DC KO DEC-2

Figura 25. Estímulo de polissacarídeos de $A$. auricula e G. lucidum em células nocautes para dectina2. O tempo de estímulo dos polissacarídeos foi de 24 horas; GI - Ganoderma lucidum Insolúvel; AI Auricularia auricula Insolúvel; concentrações de $100 \mu \mathrm{g} / \mathrm{mL}$ para todas as frações testadas; Controle (agonista dectina-2) - Furfurmana, $5 \mu \mathrm{g} / \mathrm{mL}$; DC - Células Dendríticas; DC KO Dectina-3 - receptor Dectina-3 não funcional; Experimento realizado em triplicata biológica. p significante quando $<0,05$.

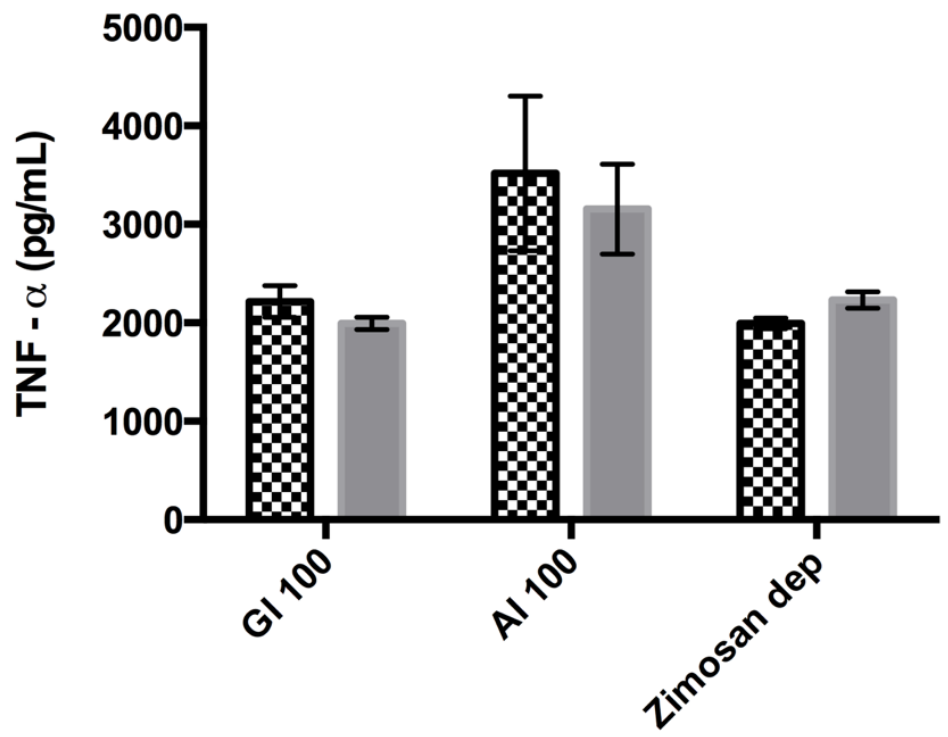

W DC WT DEC-3 DC KO DEC-3

Figura 26. Estímulo de polissacarídeos de A. auricula e G. lucidum em células nocautes para dectina3. O tempo de estímulo dos polissacarídeos foi de 24 horas; GI - Ganoderma lucidum Insolúvel; AI Auricularia auricula Insolúvel; concentrações de $100 \mu \mathrm{g} / \mathrm{mL}$ para todas as frações testadas; Controle Zimosan dep - zimosan depletado $100 \mu \mathrm{g} / \mathrm{mL}$; DC - Células Dendríticas; DC KO DEC-2 - receptor Dectina-1 não funcional; Experimento realizado em triplicata biológica. p significante quando $<0,05$. 
Os resultados demonstraram que os polissacarídeos insolúveis do cogumelo $A$. auricula ligaram-se apenas em dectina-1 enquanto a fração insolúvel de Ganoderma lucidum ligou-se a dectina-1, mas também ao receptor TLR2 e TLR4.

O receptor fagocítico dectina-1 está envolvido no reconhecimento de patógenos fúngicos. A ativação deste receptor estimula uma variedade de respostas celulares resultando na iniciação de várias cascatas de sinalização, como a via canônica de ativação de NFkB dependente de Syk. Contudo, a sinalização via Raf1 também pode ocorrer, iniciando a ativação não canônica de NFkB (Rogers et al., 2005; Gringhuis, et al., 2009; Drummond e Brown, 2011).

A molécula zimosan foi utilizada como controle positivo, uma vez que este estimula a produção de TNF- $\alpha$ via dectina-1/SyK/NFkB (Goodridge et al., 2011). A avaliação da participação das moléculas Syk e Raf-1, bem como a ativação de NFkB na sinalização dos polissacarídeos de A. auricula e G. lucidum, estão demonstrados na figura 27.

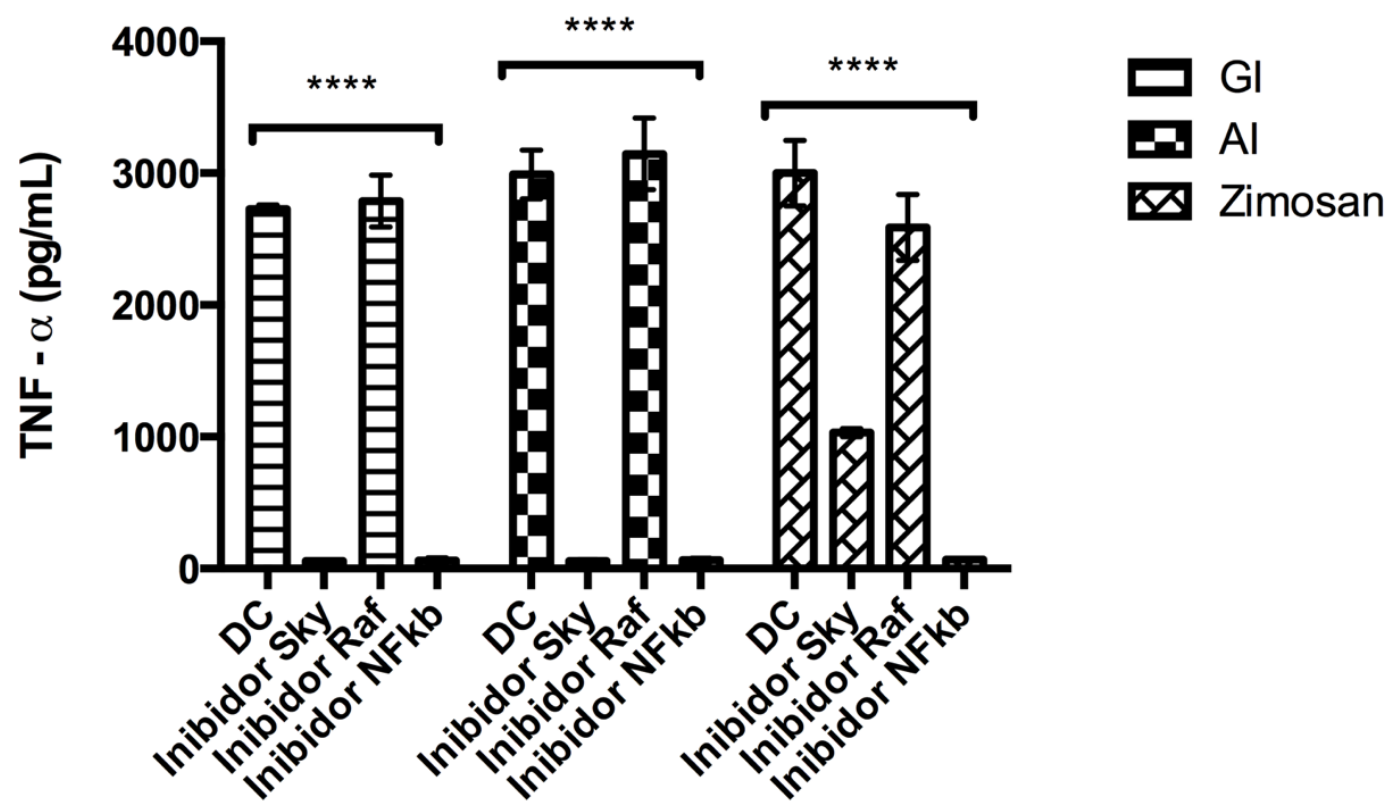

Figura 27. Avaliação da participação de Syk e Raf-1 na sinalização de Auricularia auricula e Ganoderma lucidum. O sobrenadante do cultivo celular foi avaliado após 24 horas de estímulo. GI Ganoderma lucidum Insolúvel; AI - Auricularia auricula Insolúvel; concentrações de $100 \mu \mathrm{g} / \mathrm{mL}$; zimosan normal - $100 \mu \mathrm{g} / \mathrm{mL}$; DC - Células Dendríticas; Análise estatística comparando controle aos bloqueios. Experimento realizado em triplicata biológica. p significante quando $<0,05$.

Após os estímulos com os polissacarídeos e utilizando os bloqueadores de Syk, Raf-1 e NFkB, foi constatada a importância da molécula adaptadora Syk na ativação de 
NFkB/TNF- $\alpha$, sendo observada a produção da citocina pela ativação do fator de transcrição pela via canônica.

\section{Avaliação da expressão das moléculas co-estimulatórias CD80, CD86 e MHC II em células dendríticas após estímulo.}

O grau de ativação das células dendríticas é correlacionado com a expressão de alguns marcadores de superfície celular, dentre eles o MHC II (Lugt et al., 2014), CD80 e CD 86. A avaliação destes após estímulo com os polissacarídeos de Auricularia auricula e Ganoderma lucidum estão apresentados na figura 28 e nos anexos 9.5 e 9.6.
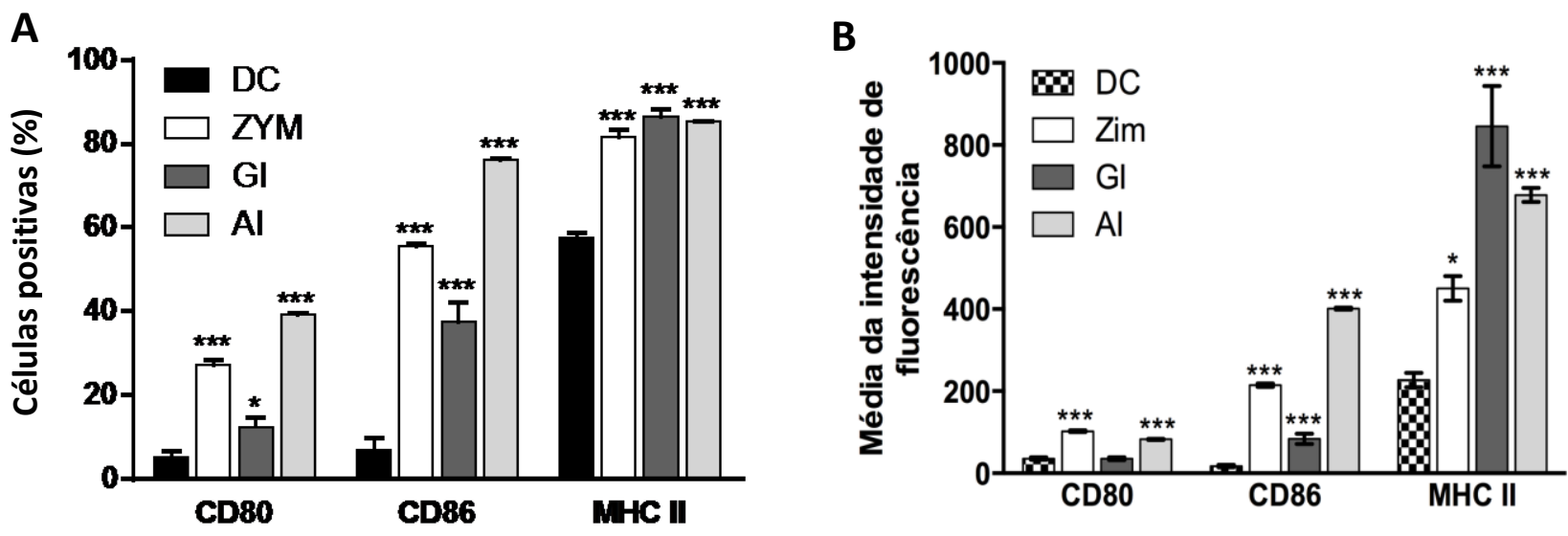

Figura 28. Fenotipagem do estimulo de polissacarídeos de A. auricula e $G$. lucidum para células dendríticas positivas para as moléculas co-estimulatórias CD80, CD86 e MHC II. O tempo de estímulo dos polissacarídeos foi de 24 horas DC - Células dendríticas, Zim - Zimosan não depletado, GI Ganoderma lucidum fração insolúvel, AI - Auricularia auricula fração insolúvel; Concentração de 100 $\mu \mathrm{g} / \mathrm{mL}$ para todas as amostras testadas; MHC II - complexo de histocompatibilidade tipo II, Isotipo CD11 $\mathrm{b}^{+}$ (A) Porcentagem de células dendríticas positivas para os receptores CD80, CD86 e MHC II estimulados com polissacarídeos; (B) Média da intensidade de fluorescência das células dendríticas positivas para CD80, CD86 e MHC II estimuladas com polissacarídeos. Análise estatística comparando células não tratadas (controle) aos tratamentos. Experimento realizado em triplicata biológica. p significante quando $<$ 0,05 .

Os polissacarídeos de Ganoderma lucidum estimularam o aumento de expressão das moléculas co-estimulatórias de expressão de superfície MHC II e CD 86, diferentemente de Auricularia auricula que estimulou a expressão de todas as moléculas 
avaliadas, um padrão semelhante, porém maior quando comparado ao controle positivo zimosan.

\section{DISCUSSÃO}

A determinação de atividade citotóxica é uma etapa necessária no estudo de moléculas com possíveis aplicações terapêuticas, e, diferentes avaliações podem ser realizadas para a sua determinação (Riss et al., 2016). A enzima LDH é um marcador de viabilidade celular, da presença de necrose tecidual e da integridade da membrana (Cummings et al., 2013), e pode ser utilizada para avaliação de efeitos gerais, como a inibição de crescimento e de morte celular em determinadas condições (Galluzzi et al., 2009; Smith, 2011). A avaliação da viabilidade das células estimuladas com as frações dos cogumelos Auricularia auricula e Ganoderma lucidum, pela da dosagem de LDH, identificou uma toxicidade celular aceitável após 48 horas de estímulo, exceto para a fração solúvel de Auricularia auricula (Figura 16).

Os ensaios utilizados para avaliação de citotoxicidade envolvem a comparação de função e/ou integridade celular e depende do tipo celular e do agente usado para a injúria/estímulo (Cummings et al., 2013). Neste trabalho foi realizada uma segunda determinação da viabilidade celular, avaliando-se a integridade nuclear utilizado o marcador iodeto de propídeo, que demonstrou não haver citotoxicidade em nenhuma das frações de cogumelos avaliadas (Figura 17). A morte celular necrótica é avaliada pela determinação de lesões na membrana plasmática. Os ensaios de citotoxicidade para avaliação de necrose basicamente são a absorção de corantes que intercalam ao DNA, caso do iodeto de propídeo, e no vazamento de moléculas intracelulares pela membrana plasmática comprometida, como o LDH (Chan et al., 2013). Neste caso, os resultados das figuras 16 e 17 demonstraram que não houve necrose celular e comprometimento da membrana, indicando que as frações não comprometeram a viabilidade celular, exceto a fração solúvel de Auricularia auricula (Figura 16).

Os estudos sobre a citotoxicidade de frações de outros cogumelos em células saudáveis, como para o tratamento de câncer e de Mycobacterium tuberculosis, bem como em monócitos humanos THP-1, demostraram que não há efeitos citotóxicos 
(Stanikunaite, et al., 2008; Tong et al., 2009; Huang et al., 2012). Contudo, a avaliação é necessária para cada modelo avaliado, uma vez que a citotoxicidade pode ocorrer, como o caso observado na amostra solúvel de A. auricula (DC e M1) (Figura 16). Uma das possíveis causas para a ação tóxica das frações de A. auricula e G. lucidum (Figura 17) poderia ser o aumento do influxo de cálcio regulado pelas mitocôndrias, uma vez que o estímulo de beta-glucanas (zimosan) resultou em um influxo em mastócitos (Coung, et $a l ., 2016)$. Outra possível causa seria o mecanismo de indução de piroptose, com aumento da ativação do inflamassoma, como descrito para beta-glucanas presentes na parede celular de hifas de Candida albicans (Wellington, 2014), contudo estes mecanismos não foram avaliados neste trabalho. O sistema imunológico, por meio de receptores, reconhece tanto beta-glucanas solúveis quanto insolúveis (Brown, 2006) (Figura 24) e devido ao tamanho, as beta-glucanas solúveis não induzem a participação do CD45 e do CD148, como relatado por Goodridge et al. (2011) e corroborado nas figuras 18 e 24 . Segundo Lee e Kim (2014), as frações insolúveis dos cogumelos Auricularia auricula e Ganoderma lucidum apresentaram uma atividade imunomodulatória quando comparada a frações solúveis. Um exemplo é a laminaria, beta-glucana solúvel extraída de algas pardas, conhecida como um antagonista dos receptores dectina-1 (Xie et al., 2010; Xu et al., 2015). Entretanto, outros estudos indicaram que ambas as frações demonstraram papéis importantes em várias funções do corpo humano, e auxiliando no tratamento de doenças relacionadas a distúrbios imunológicos, como no aumento da quimiotaxia e adesão dos neutrófilos e no sinergismo de fatores de crescimento mielóide (Ali, 2009; Revskaya et al., 2012).

Dentre as citocinas produzidas por estes polissacarídeos (Fuentes et al., 2011), estão TNF- $\alpha$, IFN- $\gamma$, IL-1 $\beta$ e IL-10 (Lindequist et al., 2005; Johnson et al., 2009). Apesar de haver semelhanças entre as beta-glucanas, estas diferem na capacidade de induzir várias respostas celulares, particularmente na produção de citocinas (Lull et al., 2005), como observado na figura 18 , uma vez que $A$. auricula estimulou a produção de TNF- $\alpha$ e IL-10 enquanto G. lucidum estimou a produção apenas de TNF- $\alpha$ em todas as células avaliadas. Além disso, a capacidade de estímulo de A. auricula (Zuo, et al., 2008) e G. lucidum (Zhu, 2007; Cheung e Ooi, 2009) na produção de TNF- $\alpha$ já foi relatada na literatura anteriormente, corroborando com os dados observados com as frações insolúveis deste trabalho (Figura 18). Ademais, a obtenção de polissacarídeos pela técnica 
de cultivo submerso resulta na obtenção de biomoléculas diferentes quanto comparada à extração utilizando-se o por corpo frutífero.

A secreção de IL-10 ocorreu apenas após a estimulação das células com as frações insolúveis de A. auricula. (Figura 18). A produção de determinadas citocinas por diferentes grupos celulares (como DCs e macrófagos) é importante nos processos de diferenciação e ativação dos linfócitos T helper (Abbas et al., 1996; Kronin et al. 2000), como células dendríticas que secretam IL-10 favorecendo um perfil de células Th2 e inibindo a síntese de IL-12 e a via Th1 (Koch et al., 1996; revisado de Kaiko et al., 2008), demonstrando a ação estimulatória dos polissacarídeos obtidos de ambos os cogumelos. Os macrófagos M2, cuja resposta é de reparo tecidual, também secretaram TNF- $\alpha$ após estímulo A. auricula, indicando que os polímeros deste macrofungo conseguem reverter a polarização da célula. Assim, as frações insolúveis de A. auricula estimularam a produção das duas citocinas avaliadas, enquanto G. lucidum demonstrou uma atividade pró-inflamatória estimulando apenas a produção de TNF- $\alpha$.

A produção de TNF- $\alpha$ é também resultado de ativação de outros receptores, além dos ligantes de beta-glucana, como o TLR-4. Neste sentido foi importante descartar que a produção desta citocina ocorreu por um ligante (LPS) de TLR-4 que poderia estar contaminando as amostras analisadas, como o LPS. Neste contexto, a análise de contaminantes das amostras deste trabalho faz-se necessária. Um dos primeiros testes descritos para a detecção indireta de LPS foi o ensaio pirogênico de coelho, que posteriormente foi substituído pelo teste de lisado de Limulus amebocyte (LAL) (Hermanns et al., 2012). Contudo, diversos estudos demonstraram que este último não é um método totalmente seguro para detecção de LPS em amostras complexas (caso das moléculas deste trabalho) (Grallert et al., 2011; Gnauck et al., 2015; Reich et al., 2016), impulsionando o desenvolvimento de outros testes, como o $\mathrm{rFC}$ (fator recombinante $\mathrm{C}$ ) e o EndoLISA (Loverock et al., 2010; Grallert et al., 2011). Uma alternativa para esta análise é o ensaio utilizando o polipeptídeo catiônico polimixina $\mathrm{B}$, um antibiótico com afinidade elevada pelo LPS, que o neutraliza (Kataoka et al., 2002; Esteban et al., 2013). Assim, as frações de cogumelos A. auricula e G. lucium foram incubadas previamente com polimixina B e sugeriram uma possível contaminação por LPS (Figura 20), o que não era esperado. A molécula LPS é um potente estimulador da resposta imune inata (Takeuchi e Akira, 2010), pela ativação direta de TLR4, reconhecendo preferencialmente o domínio Lipídeo A da molécula LPS (Knirel e Valvano, 2011). Dessa forma, as frações 
dos cogumelos foram reavaliadas, estimulando células dendríticas contendo o receptor TLR4 funcional ou ineficiente, cujo resultado sugeriu novamente a contaminação somente das frações de G. Lucidum (Figura 21). Contudo, estudos anteriores demonstraram uma interação entre os polissacarídeos de G. lucidum e o receptor TLR4 (Batbayar et al., 2011) para a produção de IL-1 em macrófagos peritoneais de Balb/C (Shao et al., 2004), o que poderia justificar o resultado dos carboidratos de Ganoderma lucidum ao receptor TLR4 deste trabalho (Figura 21). Considerando o resultado da figura 19 (avaliando comparativamente as amostras tratadas e não tratadas com remoção de lipídeos), pode-se inferir que as frações de G. lucidum não estariam contaminadas com LPS. Uma possível justificativa para os resultados observados no ensaio de polimixina B (Figura 20) seria uma ligação inespecífica de polimixina B às regiões semelhantes entre aquelas observadas no LPS e que também podem estar presentes nas frações dos cogumelos.

As atividades das beta-glucanas descritas na literatura não estão diretamente relacionadas com a sua internalização. O processo de fagocitose envolve a etapa de internalização das partículas estranhas ao hospedeiro, processo necessário para a eliminação de microrganismos, além de ser essencial para o processamento e apresentação antigênica. No entanto, a ativação celular não depende do processo de fagocitose, como na produção de citocinas, podendo ser induzidas na ausência da internalização do alvo (Underhill e Goodridge, 2012). Os polissacarídeos avaliados neste trabalho (Figura 22) não necessitaram da internalização para desencadear a sinalização intracelular e posterior produção da citocina TNF- $\alpha$. Segundo Underhill e Goodridge (2012), polissacarídeos de massa molecular elevada induzem um processo conhecido como fagocitose "frustrada" e apesar da falta de internalização podem produzir uma grande quantidade de citocinas pró-inflamatórias. No entanto é importante ressaltar a capacidade de internalização das beta-glucanas pelo mecanismo de endocitose, como observado por Herre e et al. (2004). Estes dados também foram analisados por Ozment e et al. (2012), que observaram partículas de beta-glucana solúveis proveniente de $S$. cerevisiae, localizadas no complexo de Golgi, indicando que as frações foram internalizadas por endocitose. A produção de TNF- $\alpha$ pelas partículas de beta-glucana insolúveis independem da fagocitose ou endocitose (McCann et al., 2005), corroborando com o resultado obtidos neste trabalho (Figura 22). As moléculas zimosan e curdlan, ambas agonistas do receptor dectina-1 (Song et al., 2015; Zhu et al., 2015) estimularam 
a produção de citocinas por mecanismos distintos, sendo que zimosan precisa ser fagocitado enquanto curdlan não (McCann et al., 2005; Calugaru et al., 2009). Todas essas diferenças observadas para as frações solúveis e insolúveis/internalizadas ou não, podem ser explicadas pelas características físicas distintas como solubilidade, cadeias principal e lateral (Ozment et al., 2012) ou pela interação com receptores distintos como observado por Goodridge et al. (2011).

No processo de internalização, a ligação aos receptores de reconhecimento padrão é muito importante para a ativação das células. Os receptores descritos como importantes nos processos de reconhecimento antigênico na imunidade inata estão associados com a sinalização intracelular e os mecanismos efetores observados. Duas classes destes receptores foram descritas como sendo os principais, os CLRs e TLRs (Medzhitov, 2009; Thaiss et al., 2016). Além do reconhecimento individual destes receptores, estes ainda cooperam sinergicamente. Recentemente, um receptor que foi considerado importante para o reconhecimento de beta-glucanas são os dectina (dectina 1-3) (Brown et al., 2006; revisado por Huang et al., 2015). Baseado na alta massa molecular e na afinidade, os polissacarídeos são capazes de interagir com vários receptores, tais como Receptor do Complemento 3 (CR3), Lactosilceramida (LacCer), dectina-1 e TLR2 (Enshasy e HattiKaul, 2013). Neste contexto, foi avaliada a capacidade dos polissacarídeos de A. auricula e G. lucidum ligarem-se aos receptores dectina-1 e TLR2 estimulando a produção de TNF- $\alpha$. A figura 23 demonstrou que a fração insolúvel de G. lucidum ligou-se aos dois receptores avaliados diferentemente de A. auricula, que se ligou apenas a dectina-1, mesmo resultado obtido pelo controle zimosan depletado, agonista apenas de dectina-1 (Megias et al., 2016).

Os resultados obtidos na figura 24 demonstraram que houve interação das frações com apenas dectina-1 dentre os receptores CLRs analisados. Assim a produção parcial de TNF- $\alpha$ pelos polissacarídeos de Ganoderma lucidum, na ausência de dectina-1 (Figura 24), sugerem que outros monossacarídeos podem estar estimulando os demais receptores, tais como CR3, TLR-2 e o receptor de manose. O receptor dectina-1 reconhece betaglucanas $(1,3)$ e $(1,6)$ solúveis e insolúveis, oriundas de várias fontes. Este receptor medeia sua própria sinalização intracelular, iniciando a produção de várias citocinas e quimiocinas como o TNF- $\alpha$, IL-2, IL-10, IL-12 e a proteína inflamatória de macrófagos 2 (MIP2) (Gantner et al., 2003; Brown et al., 2003; Steele et al., 2003; Rogers et al., 2005). Os níveis de citocinas produzidas pelas células são mais elevados quando ocorre 
a co-ativação dos receptores dectina-1 e TLR2 (Underhill e Goodridge (2012), cujos dados deste trabalho demostraram esta ligação cruzada dos receptores nas frações do $G$. lucidum, que também aumentou a produção de TNF- $\alpha$ enquanto comparado com as frações de Auricularia auricula (Figura 23). A capacidade de beta-glucanas provenientes de G. lucidum ligarem-se a dectina-1 foi descrita anteriormente (Batbayar et al., 2011; Wang et al., 2012). Contudo, não existem dados na literatura que demonstraram a ligação de dectina-1 aos polissacarídeos de A. auricula, sendo este um dos primeiros trabalhos que relata este reconhecimento.

Para corroborar com o resultado obtido da figura 24, um sistema de linfócitos transgênicos que indicou a ligação de das frações solúveis e insolúveis de G. lucidum e A. auricula apenas ao receptor dectina-1, células contendo receptores ineficientes de dectina-2 e 3 foram estimuladas com frações insolúveis dos macrofungos (Figura 25 e 26). Os resultados indicaram que a ausência funcional dos receptores dectina- 2 e 3 não interferiu na produção de TNF- $\alpha$. Alguns receptores CLRs formam homo ou hetero oligômeros para aumentar a avidez por ligantes multivalentes (Cummings e McEver, 2009) e potencializar a resposta, como dectina-3 (MCL) e dectina-2 que formam um complexo heterodimérico para aumentar a habilidade de reconhecimento a Candida albicans (Zhu et al., 2013). Ademais, dectina-3 também se associa com Mincle, aumentando a expressão do próprio Mincle (Lobato-Pascual et al., 2013), porém a atividade biológica da associação destes receptores não está claramente definida (Miyake et al., 2015). Esta resposta potencializada pela associação dos receptores não foi observada com as frações insolúveis estudadas de A. auricula (Figuras 21, 23, 24, 25 e 26) e G. lucidum (Figuras 24, 25 e 26). Uma das preocupações deste trabalho foi que outros monossacarídeos presentes nas frações pudessem interferir na ativação das células estudadas. No entanto, os monossacarídeos estavam presentes tanto nas frações solúveis como nas insolúveis e foi observado atividade nas frações insolúveis avaliadas.

A ativação de Dectina-1 resulta na transdução de sinal pela via de sinalização ITAM/Syk/CARD9 (Drummond et al., 2011; Drummond et al. 2016). À jusante de Syk, CARD9 forma um complexo com BLC10 e MALT1, levando à ativação do fator de transcrição NF-kB (Lionakis e Netea, 2013). Gringhuis et al. (2009) descreveram que curdlan sinaliza para uma segunda via independente de Syk, mas que também ativa NFkB, denominada de via não canônica, dependente de Raf-1 (Zhao et al., 2016). Desta forma, avaliou-se qual destas vias de ativação foi desencadeada pelos polissacarídeos de 
Auricularia auricula e Ganoderma lucidum. O resultado (Figura 27) demonstrou que as frações de ambos os cogumelos acionaram somente a via de sinalização canônica e consequentemente a ativação do fator de transcrição NF-kB e produção de TNF- $\alpha$ em células dendríticas, o que pode inferir em mecanismos da resposta imune distintos.

Um outro mecanismo de avaliação da ativação celular é o aumento da expressão de moléculas co-estimulatórias presentes na membrana celular. Dentre estas moléculas estão aquelas que permitem uma maior interação entre células apresentadoras de antígenos (APCs) e linfócitos T (Fooksman et al., 2010; Lim et al., 2012). As moléculas co-estimulatórias expressas pelas células dendríticas são fundamentais para a correta ativação da resposta imune adaptativa, destacando-se CD28, CD80 e CD86 (Lim et al., 2011; Lim et al. 2012). Avaliando a capacidade de as frações insolúveis de Ganoderma lucidum, Auricularia auricula e zimosan (controle) ativarem moléculas co-estimulatórias em células dendríticas, houve um nível de expressão aumentado das moléculas CD 80 (apenas Auricularia auricula e zimosan), CD86 e MHC II (todos) significativo quando comparado aos níveis basais (Figura 28). Além disso, relatos da literatura também mencionam a capacidade de outros polissacarídeos estimularem o aumento dos níveis de expressão de CD80, CD86 e MHC II, como curdlan (Kim et al., 2016) e LPS (Wei et al., 2011). O aumento da expressão destas moléculas pode contribuir para uma resposta imune adaptativa mais efetiva, podendo estas frações ser utilizadas como adjuvante de tratamento de algumas doenças que cursam juntamente à depressão da resposta imune celular. Uma fração polissacarídica de G. lucidum apresentou a capacidade de ativar células dendríticas maduras, aumentando a expressão de CD40, CD54, CD80, CD83, CD86 e MHC II, bem como a ativação de linfócitos TCD4 e TCD8 (Lai et al., 2010; Dhama et al., 2015). Não foram encontrados relatos na literatura referente ao aumento da expressão de CD 80, CD86 e MHC II após estímulo com polissacarídeos de A. auricula. Ademais, os polissacarídeos de cogumelos induzem um efeito regulatório na maturação e função de células dendríticas, o que consequentemente pode aumentar a capacidade de DCs promoverem a proliferação de células T virgens ativa a resposta imune mediada por linfócitos. Vários extratos de macrofungos apresentam a habilidade de modular a capacidade de diferenciação de células $\mathrm{TCD}^{+}$que promovem uma polarização Th1 ou Th2, causando efeitos particulares em diversas doenças (Borchers et al., 2004; Lull et al., 2005). Além disso, a co-estimulação de células dendríticas propicia sinais importantes 
que podem influenciar, de tal modo que resultam na indução tanto de células $T$ efetoras como regulatórias (Steinman, 2003; Zygmunt e Veldhoen, 2011; Huang et al., 2013a).

Assim, conclui-se que os polissacarídeos insolúveis de G. lucidum e A. auricula foram capazes de estimular as células inatas de maneira distinta, secretando por meio dos receptores TLR2, TLR4 e dectina-1 e da via canônica de sinalização as citocinas TNF- $\alpha$ e IL-10, bem como estar relacionado na imunidade adaptativa. 
PARTE 3. A atividade imunomodulatória dos polissacarídeos oriundos de Auricularia auricula auxiliam a imunidade inata e a sobrevida de animais infectados pelo fungo patogênico Cryptococcus neoformans.

Neste capítulo foi avaliada a atividade das frações insolúveis de A. auricula e G. lucidum nas infeções in vitro analisando-se (1) a capacidade de adesão e internalização; (2) a capacidade microbicida (3) a produção de citocinas pró-inflamatórias e $\mathrm{NO}^{-}$(4) a produção de espécies reativas de oxigênio; (5) a expressão de genes relacionados à defesa da imunidade inata; (6) e na infecção in vivo avaliando (7) a capacidade de aumentar a sobrevida de animais experimentalmente infectados.

\section{MATERIAIS E MÉTODOS}

Avaliação do índice de adesão e internalização de Cryptococcus neoformans após estímulo com frações de Auricularia auricula e Ganoderma lucidum.

As leveduras de C. neoformans (var. grubii sorotipo A, H99) foram incubadas em meio Sabouraud (Acumedia, ref.7617) líquido estéril à $37^{\circ} \mathrm{C}$, sob agitação de $120 \mathrm{rpm}$, durante 24 horas. Após este período, as leveduras foram lavadas três vezes com PBS 1X, quantificadas e em seguida opsonizadas com anticorpo 18B7 $(5 \mu \mathrm{g} / \mathrm{mL}$ ) (que reconhece GXM, cedido gentilmente pelo Dr. Arturo Casadevall, Universidade Johns Hopkins, EUA) durante 1 hora, a $37^{\circ} \mathrm{C}, 5 \% \mathrm{CO}_{2}$.

As células DC, M1 e M2 foram cultivadas em meio RPMI estéril (nas mesmas condições descritas anteriormente, Parte 2) em placa de 96 poços contento $5 \times 10^{4}$ células, sob estímulo de frações insolúveis $(100 \mu \mathrm{g} / \mathrm{mL})$ durante 24 horas, a $37^{\circ} \mathrm{C}, 5 \% \mathrm{CO}_{2}$. Posteriormente, adicionaram-se as leveduras às células, em uma proporção de cinco leveduras para uma célula (MOI 5:1), durante 2 horas. Em seguida, após três lavagens com PBS (1X) utilizou-se a coloração do kit panótico rápido (LB laborclin ref. 620529) 
para auxiliar na contagem de leveduras aderidas à membrana celular ou internalizadas. $\mathrm{O}$ cálculo do índice de internalização foi baseado em Thomaz (2012).

\section{Determinação da atividade microbicida, produção de citocinas e óxido nítrico durante a infecção por Cryptococcus neoformans após estímulo com frações de Auricularia auricula e Ganoderma lucidum.}

Nestes experimentos, células dendríticas e macrófagos (M1 e M2) foram cultivados em meio RPMI estéril (nas mesmas condições descritas anteriormente, Parte II) em placa de 96 poços contento $5 \times 10^{4}$ células, sob estímulo de frações insolúveis de polissacarídeos, um agonista de dectina-1, zimosan depletado $(100 \mu \mathrm{g} / \mathrm{mL})$, um agonista de TLR-2 - Pam3 (300 $\mu \mathrm{g} / \mathrm{mL})$ e um agonista de TLR-4 - LPS (500 ng/mL), durante 12 horas, a $37^{\circ} \mathrm{C}, 5 \% \mathrm{CO}_{2}$. Posteriormente, leveduras de $\mathrm{H} 99$ previamente opsonizadas, foram adicionadas no tempo de 24 horas (MOI 5:1). Após os períodos de incubação, o sobrenadante foi coletado para análises e os poços foram lavados cinco vezes com RPMI. Em seguida, as células foram lisadas com uma solução aquosa de dodecil sulfato de sódio (SDS) 0.05\% (Bio-Rad, (ref. 1610302), diluídas em PBS (1X) numa proporção de 1:100, plaqueadas em meio Sabouraud Ágar (ref. 7150, Acumedia) estéril e incubadas à $37^{\circ} \mathrm{C}$ por 48-72 horas. A porcentagem de eliminação de $C$. neformans pelas células avaliadas foi obtida pela diferença entre os números de unidade formadora de colônias durante os dois tempos avaliados, 2 e 24 horas para os experimentos de unidades formadoras de colônia.

O sobrenadante do cultivo celular de DC, M1 e M2 foi coletado antes e após os períodos de infecção avaliados para dosagem das citocinas TNF- $\alpha$ e IL-1 $\beta$ (utilizando a técnica de ELISA, kits de TNF- $\alpha$ e Mouse IL-1 beta ELISA Ready-SET-Go! ${ }^{\circledR}$ Ebioscience, de acordo com as instruções do fabricante).

A dosagem indireta de oxido nítrico $\left(\mathrm{NO}^{-}\right)$foi feita a partir do sobrenadante coletado antes e após a infecção, baseando-se no protocolo de Green et al. (1981), formando a reação colorimétrica de Griess. Brevemente, as estimativas dos níveis de NO foram obtidas a partir do consumo de elétrons de $\mathrm{NO}_{3}{ }^{-}$em $\mathrm{NO}_{2}{ }^{-}$pela adição de

sulfanilamida, que reagindo forma um composto diazônico $\left(\mathrm{NO}_{2}{ }^{-}\right)$. Este reage com 
bicloridrato-N-(1-naftil)-etilenodiamina para formar um composto de coloração rósea, quantificado através de espectrofotômetro $(520-550 \mathrm{~nm})$. Os valores analisados foram obtidos baseando-se na curva padrão, cujos valores foram de 1,56, 3,12, 6,24, 12,48, 24,96, 49,92 e 99,4 micromolar $(\mu \mathrm{M})$ (Green et al., 1981; revisado de Siqueira, 2010).

\section{Avaliação da produção de espécies reativas de oxigênio durante a infecção por Cryptococcus neoformans após estímulos de Auricularia auricula e Ganoderma lucidum.}

A avaliação da produção de espécies reativas de oxigênio foi realizada pela técnica de citometria de fluxo. Assim, as células M2 foram cultivadas em meio RPMI estéril (nas mesmas condições descritas anteriormente, Parte 2) na quantidade de $3 \times 10^{6}$ (placa de seis poços) por 12 horas com estímulos de frações insolúveis de $100 \mu \mathrm{g} / \mathrm{mL}$ de A. auricula e G. lucidum a $37^{\circ} \mathrm{C}, 5 \% \mathrm{CO}_{2}$. Após o período de incubação das frações, as células foram marcadas utilizando o kit Cell ROX Deep Red (ref. C10422, Thermo Fisher) de acordo com as instruções do fabricante. Posteriormente à marcação, as células foram desaderidas, lavadas duas vezes com PBS e $2 \%$ de soro, e ressuspendidas com o mesmo tampão de lavagem para leitura no citômetro. As leveduras de $C$. neoformans foram previamente mortas por calor, incubadas a $65^{\circ} \mathrm{C}$ por 30 minutos. Em seguida, foram lavadas três vezes com PBS (1X) e opsonizadas com anticorpo 18B7 conforme protocolo prévio descrito na Parte 2. Após, leveduras mortas por calor foram incubadas por duas horas com as células M2 (MOI 5:1) que foram previamente estimuladas com polissacarídeos insolúveis dos cogumelos avaliados. Posteriormente ao período de infecção, as células foram marcadas (utilizando o kit descrito acima), desaderidas, lavadas duas vezes (PBS e $2 \%$ de soro fetal bovino) e ressuspendidas no mesmo tampão de lavagem para análise no citômetro. Para a estratégia de seleção de células positivas foram (1) selecionadas as populações de células de acordo com tamanho e granulosidade para o tipo celular (BMM) (SSC-A vs FSC-A), (2) excluídos os doublets (grumos de células) (FSC-A vs FSC-W) e (3) selecionados as células positivas para o marcador de identificação anticorpo-ROS-APCS (Anexo 9.8). 


\section{Ensaio de PCR quantitativo em tempo real (qRT-PCR) em células M2 estimuladas com frações de Auricularia auricula e Ganoderma lucidum e infectadas com Cryptococcus neoformans.}

As células M2 foram cultivadas em meio RPMI estéril (nas mesmas condições descritas anteriormente) na quantidade de $3 \times 10^{6}$ (placa de seis poços) com frações insolúveis de $100 \mu \mathrm{g} / \mathrm{mL}$ dos cogumelos por 12 horas, a $37^{\circ} \mathrm{C}, 5 \% \mathrm{CO}_{2}$. Posteriormente, o RNA das células estimuladas foi extraído utilizando Trizol (Invitrogen, ref. 15596-026), conforme protocolo previamente estabelecido (Invitrogen, 2016). O RNA foi quantificado e armazenado a $-80{ }^{\circ} \mathrm{C}$. Outro grupo experimental de macrófagos M2 foi previamente estimulado com frações insolúveis $(100 \mu \mathrm{g} / \mathrm{mL})$ dos polissacarídeos estimulados durante 12 horas e em seguida, infectado com C. neoformans opsonizado com anticorpo IgG 18B7 (MOI 5:1) por 2 horas. Após o período de infecção, o RNA das células foi extraído utilizando o mesmo protocolo mencionado. A concentração e a pureza do RNA extraído foram avaliadas por espectrofotometria (NanoDrop 2000, Thermo Scientific), aferindo a absorbância em $260 \mathrm{~nm}$ e a razão de $\mathrm{A}_{260} / \mathrm{A}_{280}$. As amostras de RNA foram aplicadas em gel de agarose $1 \%$ corado com brometo de etídeo $(0,5 \mu \mathrm{g} / \mathrm{mL})$ para avaliar integridade e qualidade do RNA (Figura 29).

Figura 29. Extração de RNA de macrófagos M2 estimulados com polissacarídeos e infectados com $C$. neoformans. O tempo de estímulo dos polissacarídeos foi de 12 horas; Tempo de infecção após estímulo com polissacarídeos foi de 2 horas; Polissacarídeos usados - GI Ganoderma lucidum fração insolúvel; AI - Auricularia auricula fração insolúvel; Concentrações de todos os estímulos foi de $100 \mu \mathrm{g} / \mathrm{mL} ; \mathrm{M} 2$ - macrófagos alternativamente ativados; 1 - macrófagos sem estímulo; 2 macrófagos infectados com $C$. neoformans; 3 e 4 macrófagos estimulados com AI e GI, respectivamente; 5 e 6 - macrófagos estimulados com AI e GI, respectivamente, e infectados com C. neformans.

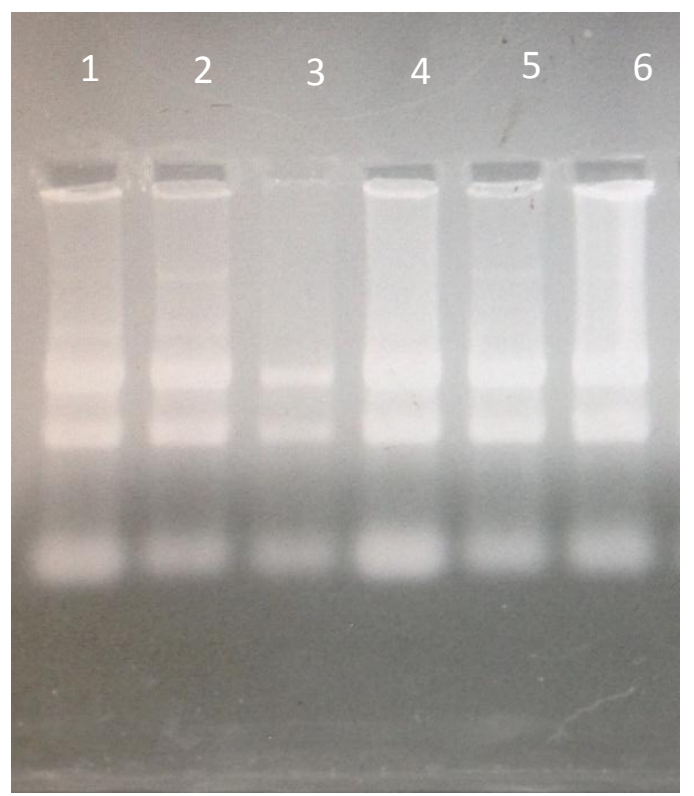


A síntese de cDNA foi feita a partir de $1 \mu \mathrm{g}$ de RNA total de cada amostra, utilizando o kit $R T^{2}$ First Strand Kit (Qiagen, ref. 330404), conforme instruções do fabricante. Para a PCR em tempo real, o kit Fast Syber ${ }^{\circledR}$ Green Master Mix (Applied Biosystems, A25776) foi utilizado, observando as recomendações do fabricante. Uma alíquota de 1/10 da reação de cDNA foi adicionada à reação de amplificação de PCR em tempo real, em um volume final de $10 \mu \mathrm{L}\left(5 \mu \mathrm{L}\right.$ de $\operatorname{SyBr}{ }^{\circledR}$ green master mix (Applied Biosystem), 3,6 $\mu \mathrm{L}$ de cDNA, $2 \mu \mathrm{L}$ de água deionizada e $0,2 \mu \mathrm{M}$ de cada oligonucleotídeo específico (forward e reverse) (Tabela 6). Todos os oligonucleotídeos foram validados previamente.

Tabela 6. Oligonucleotídeos utilizados para a qRT-PCR.

\begin{tabular}{|c|c|c|}
\hline Gene & Primer forward $\left(5^{\prime} \rightarrow 3^{\prime}\right)$ & Primer reverse $\left(5^{\prime} \rightarrow 3^{\prime}\right)$ \\
\hline Ill0 & CGCAGCTCTAGGAGCATGTG & GCTCTTACTGACTGGCATGAG \\
\hline Illr1 & TGCTGGTCAGGAGACTTTCA & CCGGCAGTTTCTCCTTAGTG \\
\hline $\begin{array}{l}\text { Nos2 } \\
\text { (iNOS) }\end{array}$ & CGAAACGCTTCACTTCCAA & TGAGCCTATATTGCTGTGGCT \\
\hline Nfkb1(p105) & AGCCAGCTTCCGTGTTTGTT & AGGGTTTCGGTTCACTAGTTTCC \\
\hline Plcg2 & TCCTTCGGTGATGACATTGA & CCACCTTCTTGTGGAACCAT \\
\hline Ptgs2 & GGAGCACCATTCTCCTTGAA & GCTGTGGATCTTGCACATTG \\
\hline Ptx3 & GGCCAAGAAAAGAATGGTTG & TGAGAACCCGATCCCAGATA \\
\hline $\begin{array}{l}\text { Mrc1 } \\
\text { (Receptor } \\
\text { Manose) }\end{array}$ & CTTATGAAGATGCTGACTGTGTAG & GTCACAGGTGTCATCCATCC \\
\hline $\operatorname{Rps} 9$ & CGCCAGAAGCTGGGTTTGT & CGAGACGCGACTTCTCGAA \\
\hline Syk & CTACCTGCTACGCCAGAGC & GCCATTAAGTTCCCTCTCGATG \\
\hline Stat1 & TCACAGTGGTTCGAGCTTCAG & GCAAACGAGACATCATAGGCA \\
\hline Tlr9 & CTACGCTTGTGTCTGGAGG & GCCAGCACAAATAGAGTCTTG \\
\hline Tnfa & GTACCTTGTCTACTCCCAGGTTCTCT & GTGGGTGAGGAGCACGTAGTC \\
\hline
\end{tabular}

Como controle interno, foram utilizados os oligonucleotídeos que amplificam o RNA mensageiro da proteína ribossomal 40S (gene Rps9). As condições de ciclagem estão descritas na tabela 7. 
Tabela 7. Condições de ciclagem utilizadas para a qRT-PCR.

\begin{tabular}{|c|c|}
\hline Ciclagem & Curva de dissociação \\
\hline $1-50^{\circ} \mathrm{C}$ por 2 minutos & $1-95^{\circ} \mathrm{C}$ por 15 minutos \\
\hline $2-95^{\circ} \mathrm{C}$ por 5 minutos & $2-60^{\circ} \mathrm{C}$ por 1 hora \\
\hline $3-95^{\circ} \mathrm{C}$ por 3 segundos & $3-95^{\circ} \mathrm{C}$ por 15 minutos \\
\hline $4-60^{\circ} \mathrm{C}$ por 30 segundos & \\
\hline Repetir passos 3 e 4 quarenta vezes & \\
\hline
\end{tabular}

Para as análises de PCR em tempo real foi utilizado o equipamento 7500 Fast Real-Time PCR System (Applied Biosystems). Os níveis de expressão de transcritos foram avaliados e calculados utilizando os valores de $\Delta$ ct das amostras e os dados foram comparados usando o método de Ct comparativo ( ${ }^{2-\Delta \Delta c t}$ ) (Livak e Schmittgen, 2001). Os resultados foram representados utilizando o valor de expressão relativa ao controle (Fold Change), onde os controles e a significância de expressão gênica foi considerada quando maior que 2 .

\section{Ensaio de curva de sobrevivência}

O ensaio de curva de sobrevivência in vivo utilizou camundongos C57BL/6, com idade de 8-12 semanas, mantidos no biotério do Instituto de Biologia da Universidade de Brasília - UnB, sob condições apropriadas e fornecimento de água e ração ad libitum. $\mathrm{O}$ número de permissão do comitê de ética foi 66729 /2016 (Anexo 9.9).

Os camundongos foram infectados por via intranasal por meio de um sistema de anestesia inalatória, contendo $1 \times 10^{4}$ leveduras de $C$. neoformans, baseando-se em Wager et al. (2014). Após três dias de infecção, os animais foram divididos em cinco grupos de cinco indivíduos cada e tratados três vezes por semana, por via intranasal ou gavagem, com frações insolúveis (contendo $25 \mu \mathrm{g}$ em 50 microlitros) dos cogumelos A. auricula ou G. lucidum, bem como PBS como controle negativo. Os grupos experimentais foram divididos em: (1) grupo PBS, (2) grupo Ganoderma lucidum gavagem, (3) grupo Ganoderma lucidum intranasal, (4) Auricularia auricula gavagem e (5) Auricularia auricula intranasal. Para análise do ensaio, os animais foram acompanhados diariamente, observando-se as manifestações clínicas da doença (como perda de peso e pelo eriçado) 
e relatando a sobrevivência dos grupos ao longo do experimento. Os dados foram analisados por meio de uma curva de sobrevida.

\section{Análise estatística}

Todos os resultados da parte III deste trabalho foram analisados com desvio padrão da média (SEM) da triplicata biológica feita de um dos experimentos independentes, de um total de 3 análises técnicas. Para avaliar estatisticamente diferenças entre grupos experimentais a análise da variância (ANOVA) e pelos métodos Sidak e Turkey foram utilizados. Para os experimentos de curva de sobrevivência os testes LogRank (Mantel-Cox) e Logrank for trend foram utilizados. O software GraphPad Prism (versão 6.0) foi utilizado para a análise dos dados, que foram considerados significantes quando $\mathrm{p}<0,05$.

\section{RESULTADOS}

Determinação do índice de adesão e internalização de leveduras de Cryptococcus neoformans após estímulo com polissacarídeos de Auricularia auricula e Ganoderma lucidum.

Para avaliar o efeito dos estímulos dos polissacarídeos de A. auricula e G. lucidum na capacidade de adesão e internalização fúngica de $C$. neoformans, foi realizado um ensaio foi feito utilizando células dendríticas e macrófagos (M1 e M2) (Figura 30). 

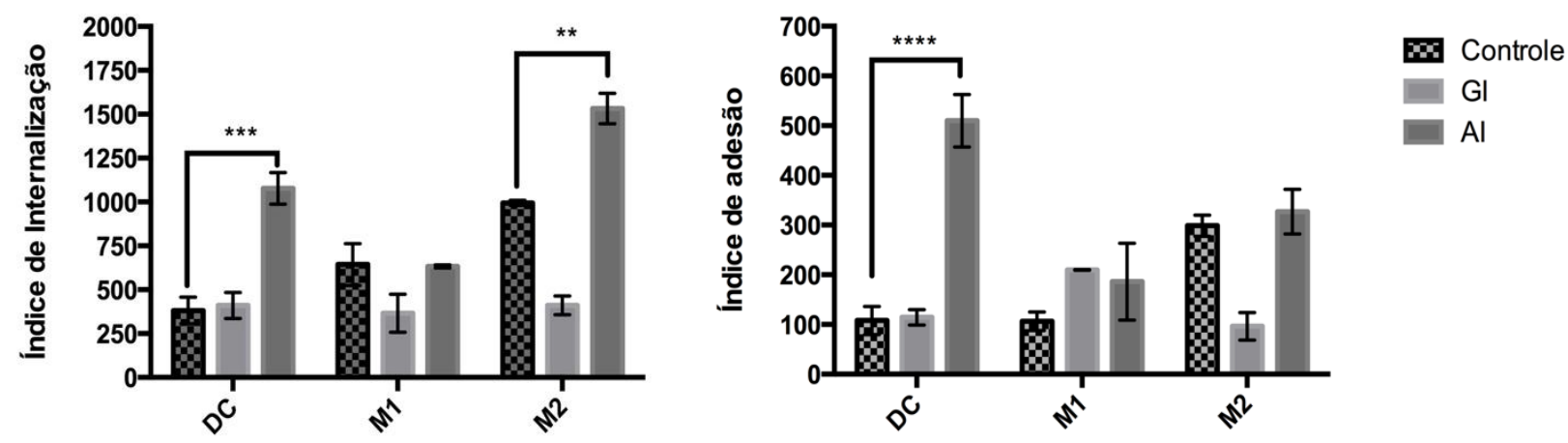

Figura 30. Índice de adesão e internalização de leveduras de $C$. neoformans após estímulo de polissacarídeos de $\boldsymbol{A}$. auricula e $\boldsymbol{G}$. lucidum. O tempo de estímulo dos polissacarídeos foi de 24 horas; Tempo de infecção após estímulo com polissacarídeos foi de 2 horas; GI - Ganoderma lucidum fração insolúvel; AI - Auricularia auricula fração insolúvel; Concentração de $100 \mu \mathrm{g} / \mathrm{mL}$; DC - células dendríticas; M1 - Macrófagos classicamente ativados; M2 - macrófagos alternativamente ativados; Experimento realizado em triplicata biológica. p significante quando $<0,05$.

Os resultados da Figura 30 demonstraram que os polímeros insolúveis de Auricularia auricula aumentaram a capacidade de adesão (células dendríticas) e internalização (células dendríticas e macrófagos alternativamente ativados, M2) destas células ao C. neoformans. A fração insolúvel de Ganoderma lucidum demonstrou que, para os macrófagos M2, as capacidades de adesão e de internalização estão diminuídas quando comparadas a células não estimuladas (controle).

Avaliação da capacidade microbicida sobre Cryptococcus neoformans de células dendríticas e macrófagos M1 e M2 estimuladas previamente com os polissacarídeos de Auricularia auricula e Ganoderma lucidum.

Para avaliar a eficácia do efeito dos estímulos dos polissacarídeos dos cogumelos estudados em células dendríticas, (M1 e M2) durante a eliminação fúngica, foram realizados ensaios de contagem de unidades formadoras de colônia e a porcentagem de atividade fungicida (Figuras 31 e 32). 
$\mathrm{DC}$

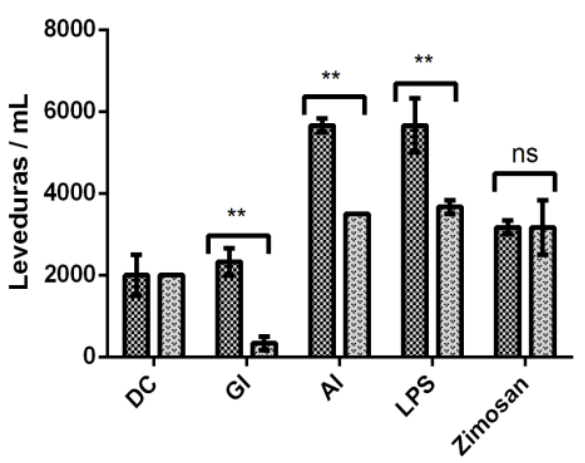

M2

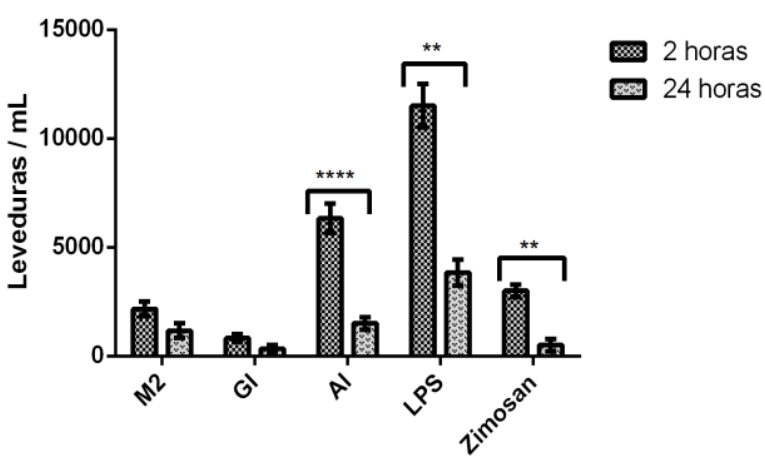

M1

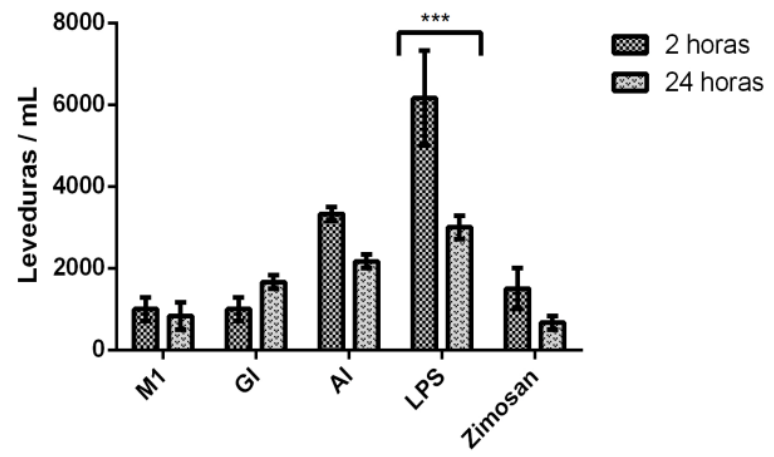

Figura 31. Ensaio de unidades formadoras de colônia de $C$. neoformans após estímulo de polissacarídeos de $\boldsymbol{A}$. auricula e G. lucidum. O tempo de estímulo dos polissacarídeos foi de 12 horas; Tempo de infecção após estímulo com polissacarídeos foi de 2 e 24 horas; GI - Ganoderma lucidum fração insolúvel $100 \mu \mathrm{g} / \mathrm{mL}$; AI - Auricularia auricula fração insolúvel $100 \mu \mathrm{g} / \mathrm{mL} ; \mathrm{PAM}_{3}-300 \mathrm{ng} / \mathrm{mL}$, LPS - $500 \mathrm{ng} / \mathrm{mL}$, Zimosan $-100 \mu \mathrm{g} / \mathrm{mL}$. DC - Células dendríticas; M1 - Macrófagos classicamente ativados; M2 macrófagos alternativamente ativados; Experimento realizado em triplicata biológica. p significante quando $<0,05$.

A figura 31 demonstra a eliminação fúngica entre os períodos de 2 e 24 horas após a infecção. A figura 32 comprova a porcentagem de eliminação fúngica comparativamente às células não estimuladas com nenhum agonista (controle). Em relação às células dendríticas, todos os tratamentos indicaram uma diminuição na quantidade de leveduras entre os tempos de 2 e 24 horas e na porcentagem de morte, exceto quando estimulados com zimosan (Figuras 31 e 32). Para macrófagos M1 os estímulos com LPS, zimosan depletado e a Auricularia auricula sugeriram uma diferença significativa entre os tempos avaliados com uma porcentagem de eliminação fúngica estatisticamente significativa ao controle (Figura 34). Os macrófagos M2, estimulados com os agonistas LPS e zimosan, e a fração da Auriculária auricula, apresentaram redução significativa tanto na diminuição de leveduras (quando analisadas em um ensaio de unidades formadoras de colônia) e na porcentagem de morte de $C$. neoformans (Figuras 33 e 34). Estes resultados indicam que o estímulo dos agonistas Auricularia auricula e Ganoderma lucidum são distintos entre células dendríticas, M1 e M2, aumentando a capacidade fungicida para M2 apenas para Auricularia auricula, o que não ocorreu com M1. 

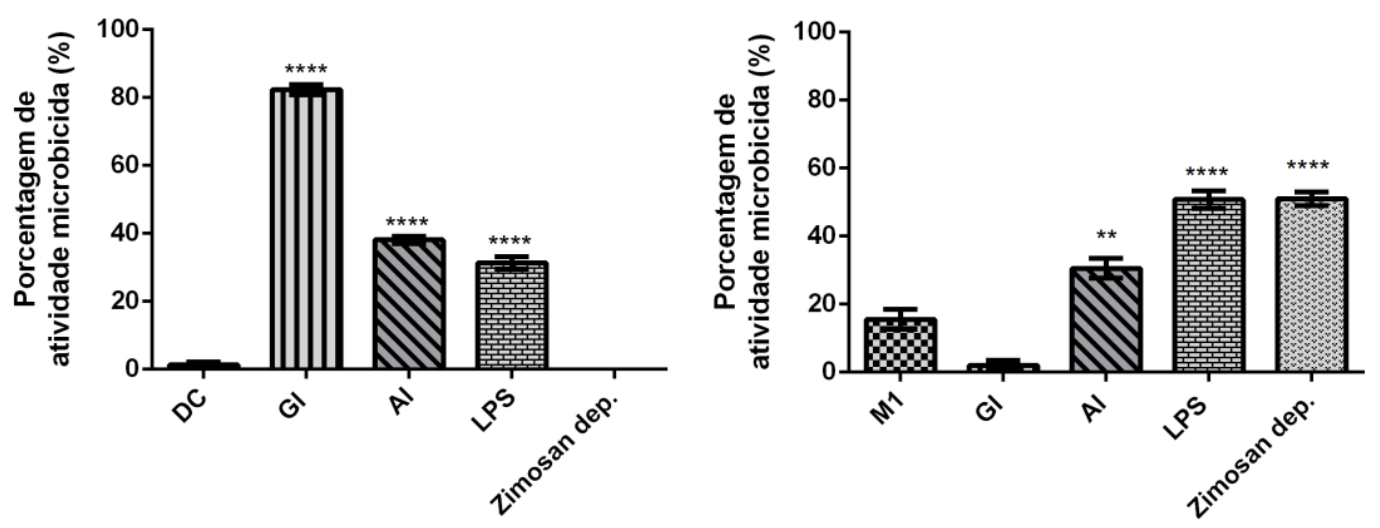

M2

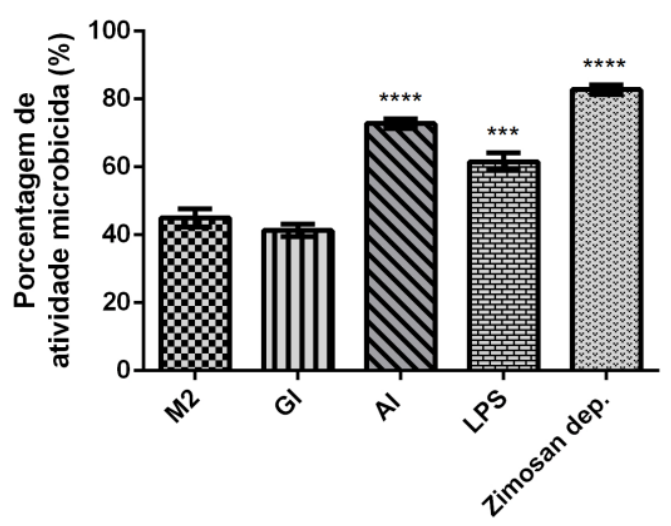

Figura 32. Porcentagem de atividade microbicida a $C$. neoformans após estímulo de polissacarídeos de $\boldsymbol{A}$. aurícula e $\boldsymbol{G}$. lucidum. Os tempos para o cálculo de porcentagem foram de 2 e 24 horas de infecção. Os polissacarídeos foram estimulados por 12 horas; GI - Ganoderma lucidum fração insolúvel $100 \mu \mathrm{g} / \mathrm{mL}$; $\mathrm{AI}$ - Auricularia auricula fração insolúvel $100 \mu \mathrm{g} / \mathrm{mL} ; \mathrm{PAM}_{3}-300 \mathrm{ng} / \mathrm{mL}$, LPS - $500 \mathrm{ng} / \mathrm{mL}$, Zimosan $100 \mu \mathrm{g} / \mathrm{mL}$. DC - Células dendríticas; M1 - Macrófagos classicamente ativados; M2 - macrófagos alternativamente ativados; Análise estatística comparando controle (célula não estimulada aos tratamentos. Experimento realizado em triplicata biológica. p significante quando $<0,05$

Avaliação da produção de óxido nítrico e da secreção das citocinas TNF- $\alpha$ e IL-1ß e do após estímulos com os polissacarídeos de Auricularia auricula e Ganoderma lucidum antes e durante a infecção por Cryptococcus neoformans.

As citocinas TNF- $\alpha$ e IL-1 $\beta$ são importantes para a resposta imune protetora do hospedeiro à infeção por C. neoformans (Guillot et al., 2008; Rohatgi, 2015). Assim, foi realizada a avaliação da produção destas moléculas antes e durante a infecção, estimulando previamente macrófagos e células dendríticas com os polissacarídeos analisados (Figuras 33 e 34). 

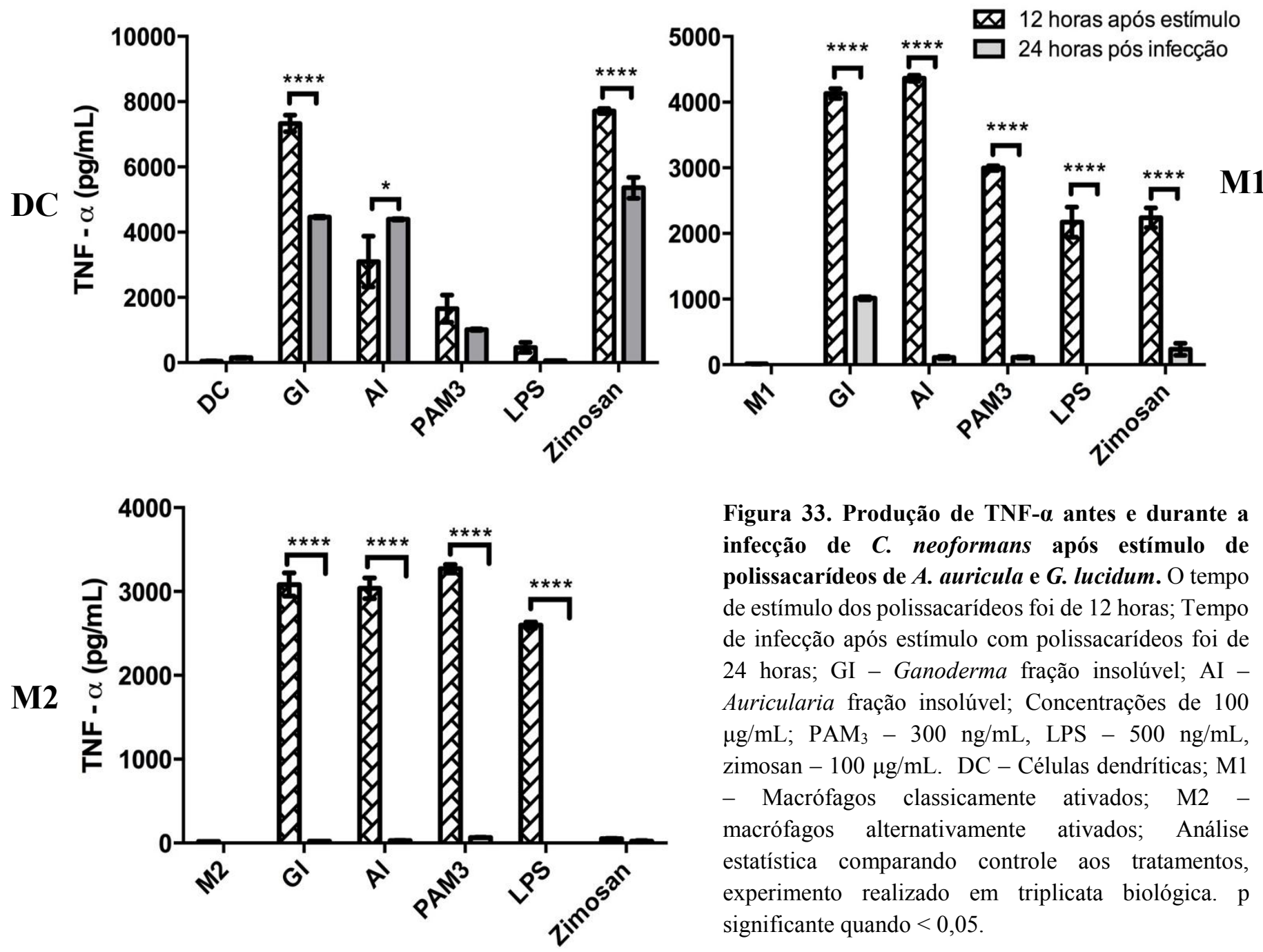

Figura 33. Produção de TNF- $\alpha$ antes e durante a infecção de $C$. neoformans após estímulo de polissacarídeos de $\boldsymbol{A}$. auricula e G. lucidum. O tempo de estímulo dos polissacarídeos foi de 12 horas; Tempo de infecção após estímulo com polissacarídeos foi de 24 horas; GI - Ganoderma fração insolúvel; AI Auricularia fração insolúvel; Concentrações de 100 $\mu \mathrm{g} / \mathrm{mL} ; \mathrm{PAM}_{3}$ - $300 \mathrm{ng} / \mathrm{mL}, \mathrm{LPS}$ - $500 \mathrm{ng} / \mathrm{mL}$, zimosan $-100 \mu \mathrm{g} / \mathrm{mL}$. DC - Células dendríticas; M1 - Macrófagos classicamente ativados; M2 macrófagos alternativamente ativados; Análise estatística comparando controle aos tratamentos, experimento realizado em triplicata biológica. $p$ significante quando $<0,05$.

Na Figura 33, as células que foram apenas estimuladas induziram níveis elevados de TNF- $\alpha$ para todos os tratamentos, exceto zimosan depletado em células M2. Após 24 horas de infecção apenas células dendríticas estimuladas com a fração de Auriculária auricula aumentaram os níveis desta citocina. Para as células M1 e M2, a produção de TNF- $\alpha$ caiu drasticamente, considerando todos os estímulos avaliados. Todas as frações insolúveis das beta-glucanas testadas neste trabalho (Figura 34) foram capazes de estimular a produção de IL-1 $\beta$, em diferentes níveis. No tempo de 24 horas somente os polissacarídeos da Auricularia auricula aumentaram discretamente os níveis de IL-1 $\beta$ em células dendríticas. 


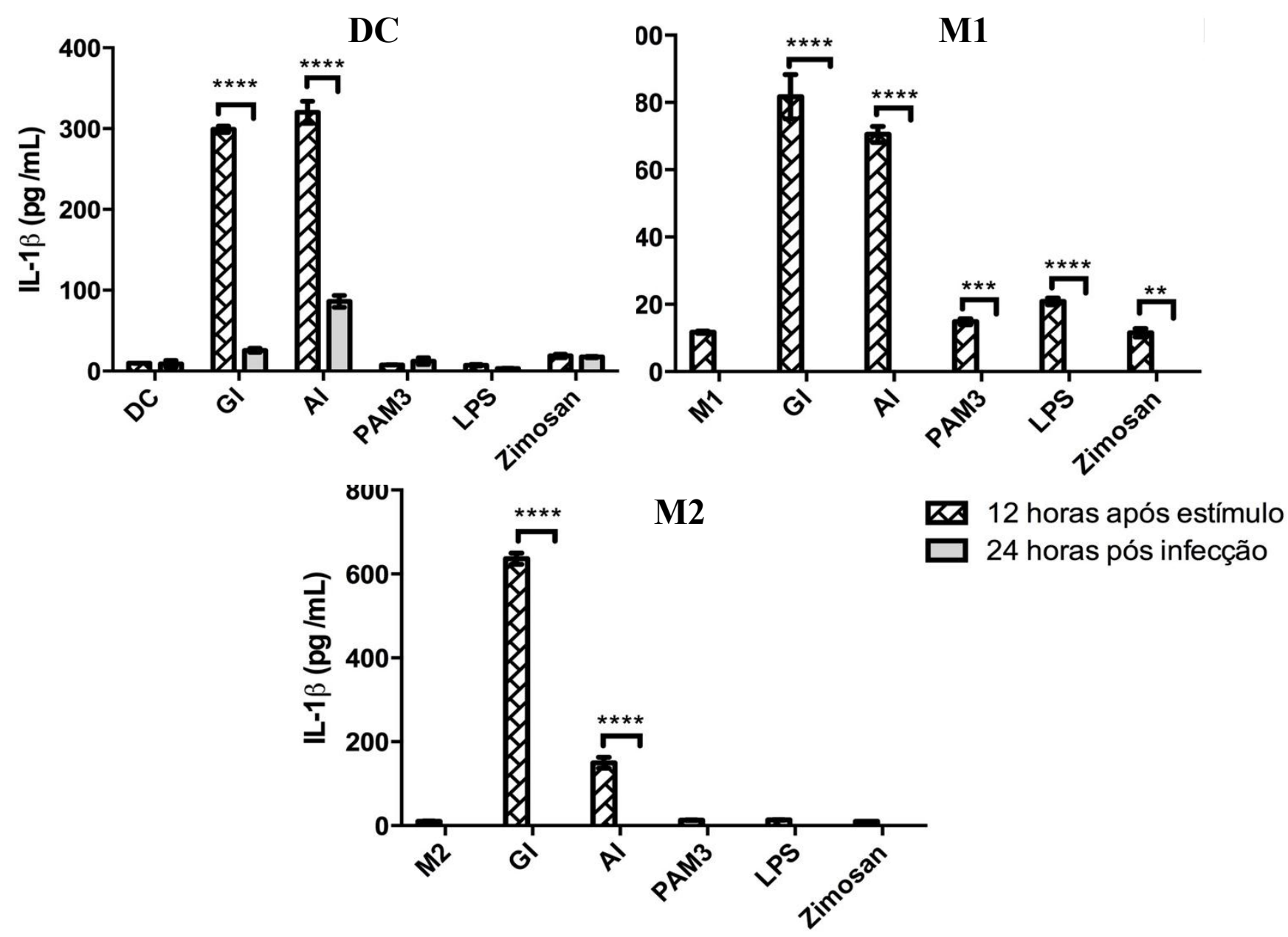

Figura 34. Produção de IL-1ß antes e durante infecção de $C$. neoformans após estímulo de polissacarídeos de $\boldsymbol{A}$. auricula e G. lucidum. O tempo de estímulo dos polissacarídeos foi de 12 horas; Tempo de infecção após estímulo com polissacarídeos foi de 24 horas; GI - Ganoderma lucidum fração insolúvel; AI - Auricularia auricula fração insolúvel; Concentrações de $100 \mu \mathrm{g} / \mathrm{mL} ; \mathrm{PAM}_{3}-300 \mathrm{ng} / \mathrm{mL}$, LPS - $500 \mathrm{ng} / \mathrm{mL}$, zimosan - $100 \mu \mathrm{g} / \mathrm{mL}$. DC - Células dendríticas; M1 - Macrófagos classicamente ativados; M2 - macrófagos alternativamente ativados; Análise estatística comparando controle aos tratamentos, experimento realizado em triplicata biológica. p significante quando $<0,05$.

Além da produção de citocinas, foram avaliados alguns mecanismos microbicidas observados pelas células da resposta imune. Neste contexto, as frações insolúveis de Auricularia auricula e Ganoderma lucidum foram avaliadas quanto a capacidade de produção de $\mathrm{NO}^{-}$antes e durante a infecção por C. neoformans (Figura 35). 

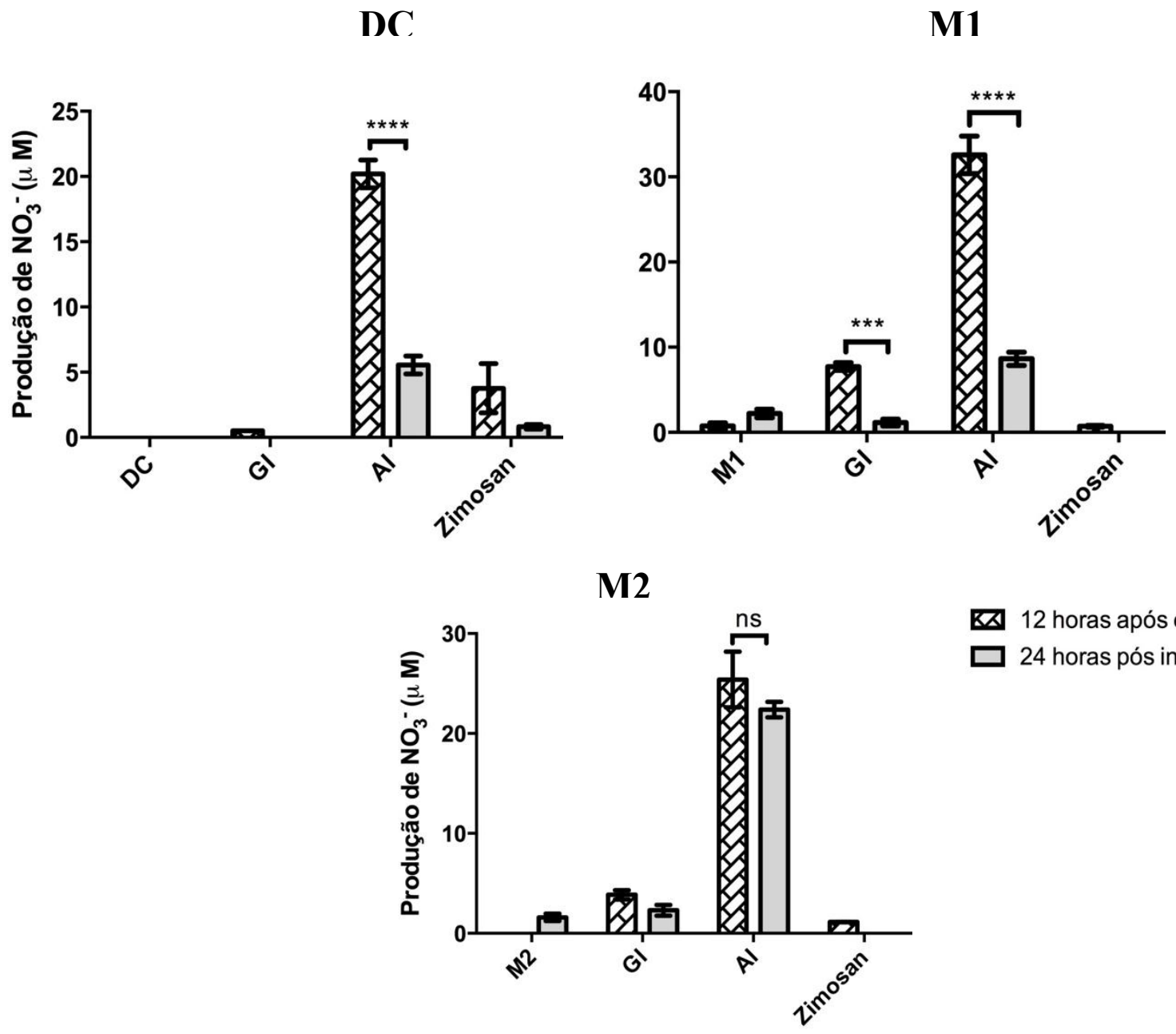

12 horas após estímulo $\square 24$ horas pós infecção

Figura 35. Produção de $\mathrm{NO}_{3}^{-}$antes e durante infecção de $C$. neoformans após estímulo de polissacarídeos de $\boldsymbol{A}$. auricula e $\boldsymbol{G}$. lucidum. O tempo de estímulo dos polissacarídeos foi de 12 horas; Tempo de infecção após estímulo com polissacarídeos foi de 24 horas; GI - Ganoderma lucidum fração insolúvel; AI - Auricularia auricula fração insolúvel; Concentrações de $100 \mu \mathrm{g} / \mathrm{mL}-100 \mu \mathrm{g} / \mathrm{mL}$. DC Células dendríticas; M1 - Macrófagos classicamente ativados; M2 - macrófagos alternativamente ativados; Análise estatística comparando controle aos tratamentos. Experimento realizado em triplicata biológica. p significativo quando $<0,05$.

Os polissacarídeos de Ganoderma lucidum, Pam 3 , LPS e zimosan depletado estimularam a produção de níveis de $\mathrm{NO}^{-}$menores que $10 \mu \mathrm{M}$, valores considerados baixos biologicamente. Entretanto, a fração de Auricularia auricula no tempo de 12 horas após estímulo, apresentou níveis de NO de $32 \mu \mathrm{M}$ (M1), $26 \mu \mathrm{M}$ (M2) e $22 \mu \mathrm{M}$ (DC) (Figura 35). Após 24 horas de infeção com o fungo, os níveis de $\mathrm{NO}^{-}$diminuíram nas culturas de DCs e macrófagos M1. Os níveis de óxido nítrico produzidos pelos 
macrófagos M2 pós 24 horas de infecção $(24 \mu \mathrm{M})$ permaneceram semelhantes, demostrando que as duas frações apresentam atividades biológicas distintas.

\section{Avaliação da produção de espécies reativas de oxigênio em macrófagos M2 estimulados com polissacarídeos de cogumelos antes e após a infecção por Cryptococcus neoformans.}

Devido ao fato de que NO apresentou níveis significativos em células alternativamente ativadas (M2) apenas para os polissacarídeos de Auricularia auricula, avaliou-se a produção de espécies reativas de oxigênio (EROs) neste tipo celular após 2 horas de infecção de $C$. neoformans (Figura 36 e anexos 9.7 e 9.8).

A

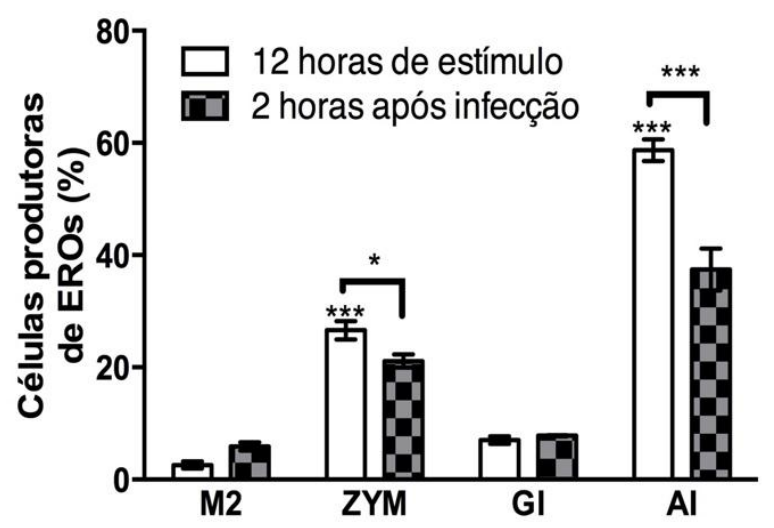

B

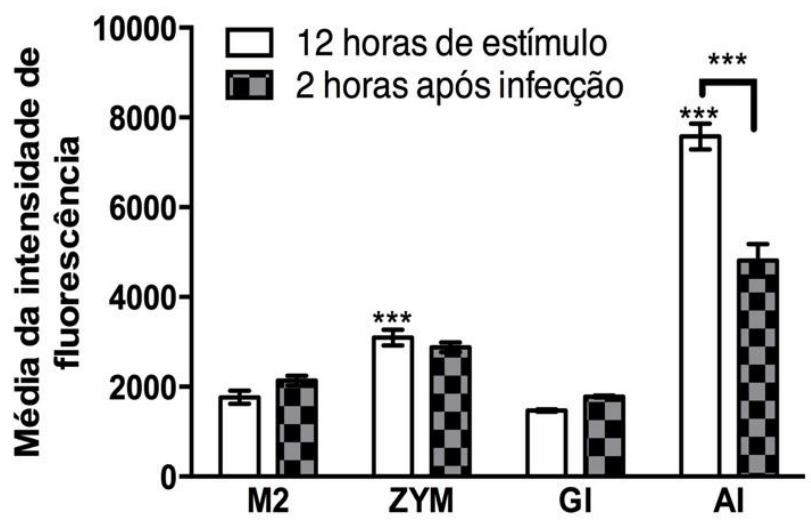

Figura 36. Produção de espécies reativas de oxigênio (EROs) por células M2 antes e durante infecção de $\boldsymbol{C}$. neoformans após estímulo de polissacarídeos de A. auricula e G. lucidum. O tempo de estímulo dos polissacarídeos foi de 12 horas; Tempo de infecção após estímulo com polissacarídeos foi de 2 horas; Zim - zimosan não depletado, GI - Ganoderma lucidum fração insolúvel; AI - Auricularia auricula fração insolúvel; Concentrações de todos os estímulos foi de $100 \mu \mathrm{g} / \mathrm{mL}$; M2 - macrófagos alternativamente ativados; (A) Porcentagem de células M2 positivas para EROs estimulados com polissacarídeos; (B) Média da intensidade de fluorescência das células M2 para EROS estimuladas com polissacarídeos. Análise estatística comparando controle aos tratamentos, experimento realizado em triplicata biológica. $\mathrm{p}$ significativo quando $<0,05$.

A figura 36 indicou que Auricularia auricula e zimosan estimularam macrófagos alternativamente ativados (M2) a produzir EROs. Contudo, após duas horas de infecção com o fungo houve uma redução na produção de EROs para células estimuladas com $A$. auricula, porém ainda estatisticamente significante quando comparada ao controle (macrófagos M2 não estimulados e infectados). A fração de Ganoderma lucidum além de 
não estimular a produção de EROs induziu a uma diminuição quando comparado aos níveis basais.

Determinação da expressão de genes de macrófagos M2 relacionada á defesa do hospedeiro na infecção por Cryptococcus neoformans.

Para avaliar a expressão de genes importantes envolvidos na resposta a $C$. neoformans, os macrófagos M2 foram estimulados e infectados, bem como o RNA foi extraído para análise. Os genes selecionados para esta análise basearam-se em resultados prévios de macrófagos M1 estimulados com zimosan e posteriormente infectados com $C$. neoformans (Figura 37). Os resultados das análises estão apresentados nas figuras 40 e 41.
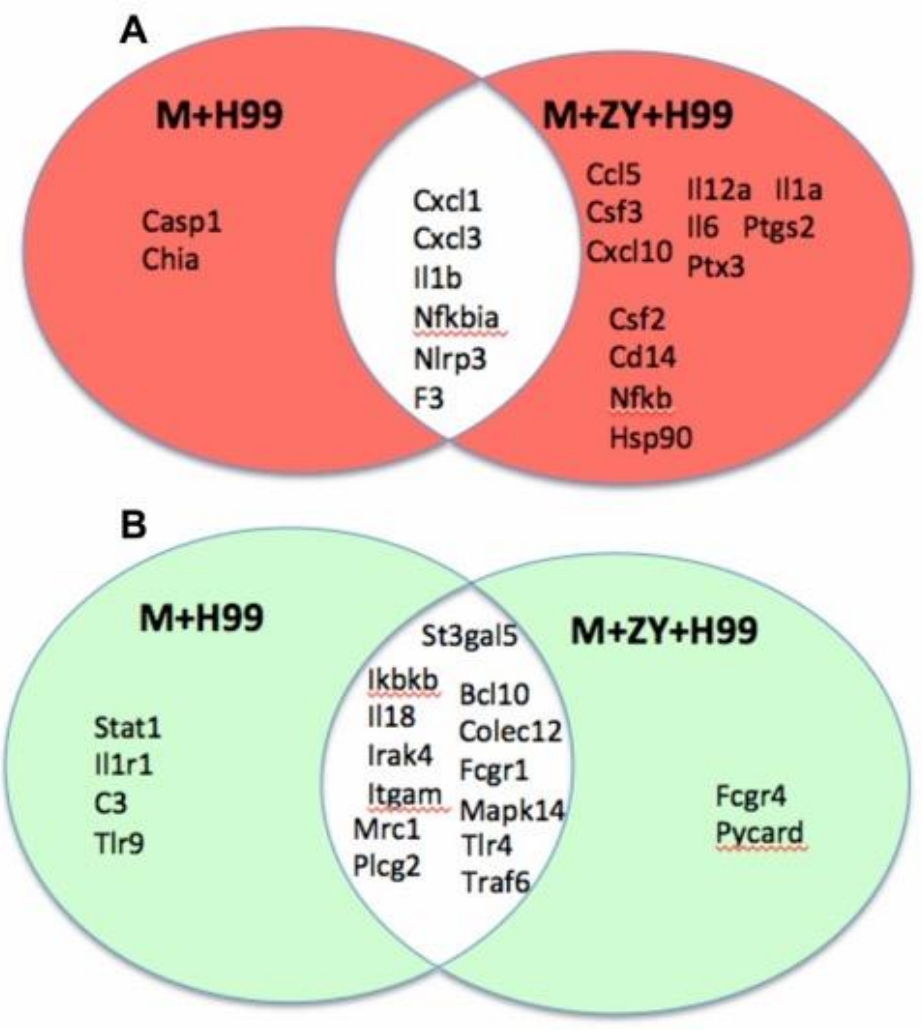

Figura 37. Avaliação da expressão gênica de macrófagos M1 estimulados e infectados com $C$. neoformans. Os genes foram regulados positivamente (A) ou negativamente (B) por $C$. neoformans, zimosan ou por ambos; H99 - C. neoformans, Zy - zimosan depletado, M - macrófagos M1. 

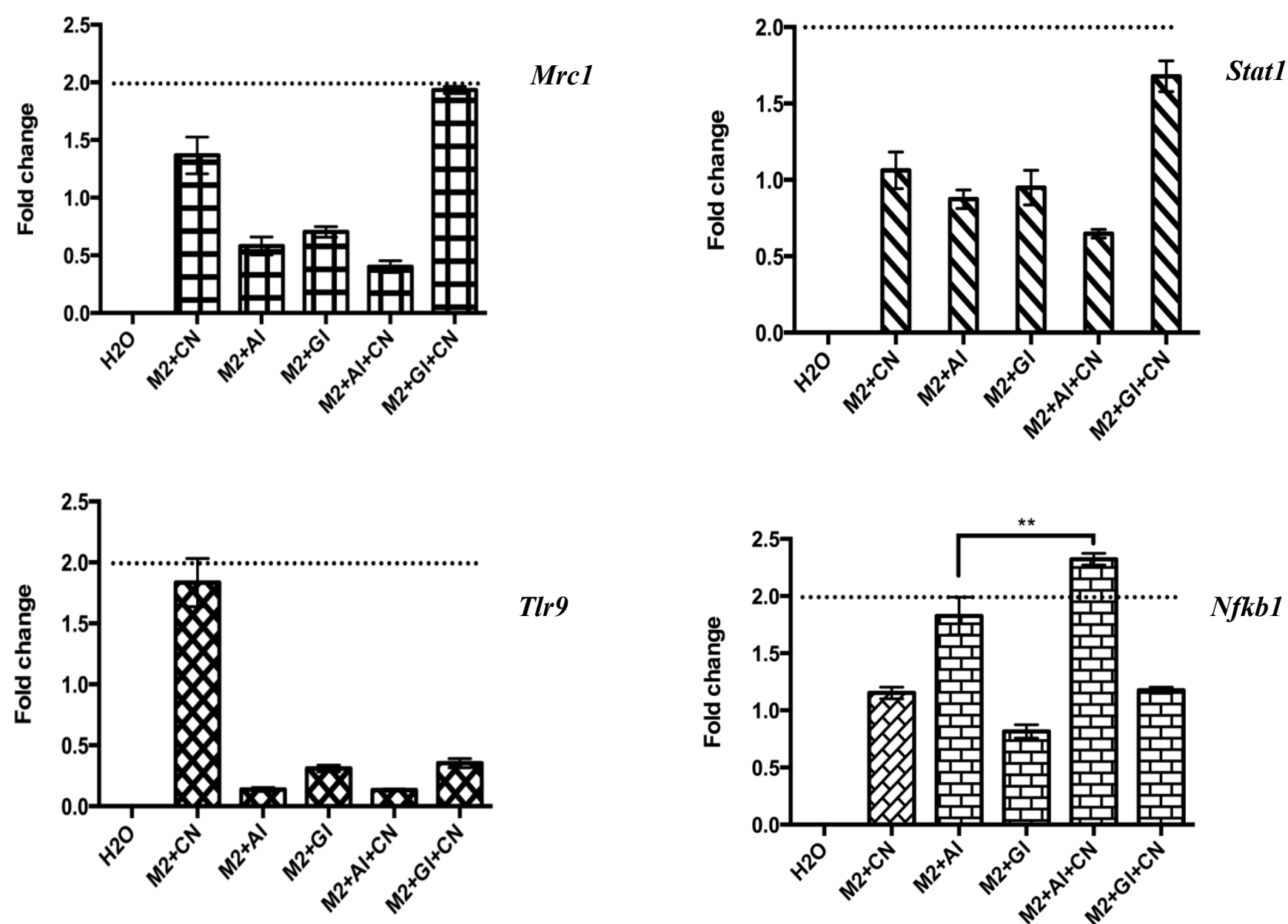

Tlr9
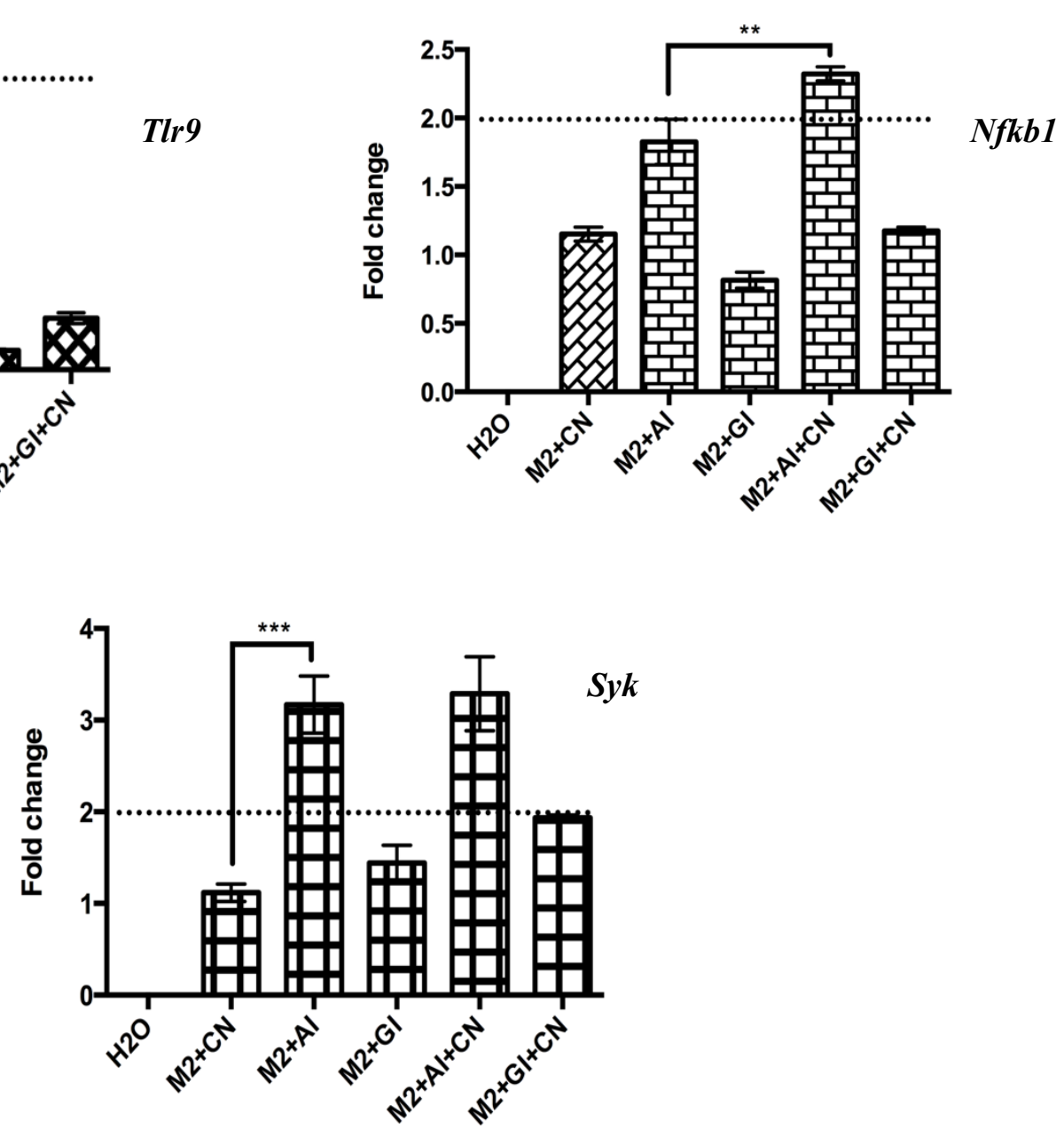

Figura 38. Comparação de expressão dos transcritos de genes relacionados à resposta imune de células M2 estimuladas com A. auricula e G. lucidum e infectadas com $\boldsymbol{C}$. neoformans. Os genes analisados codificam os receptores TLR9 e Manose), a molécula adaptadora Syk, e os fatores de transcrição STAT1 e NFkB1 (p105). O tempo de estímulo dos polissacarídeos foi de 12 horas; Tempo de infecção após estímulo com polissacarídeos foi de 2 horas; GI - Ganoderma fração insolúvel $100 \mu \mathrm{g} / \mathrm{mL}$; AI - Auricularia auricula fração insolúvel $100 \mu \mathrm{g} / \mathrm{mL}$; M2 - macrófagos alternativamente ativados; Fold change foi calculado pelo método $2^{-\Delta \Delta \mathrm{Ct}}$. Acima das linhas pretas pontilhadas significam expressão significativa, acima de 2 . Experimento realizado em triplicata biológica. p significativo quando $<0,05$ 


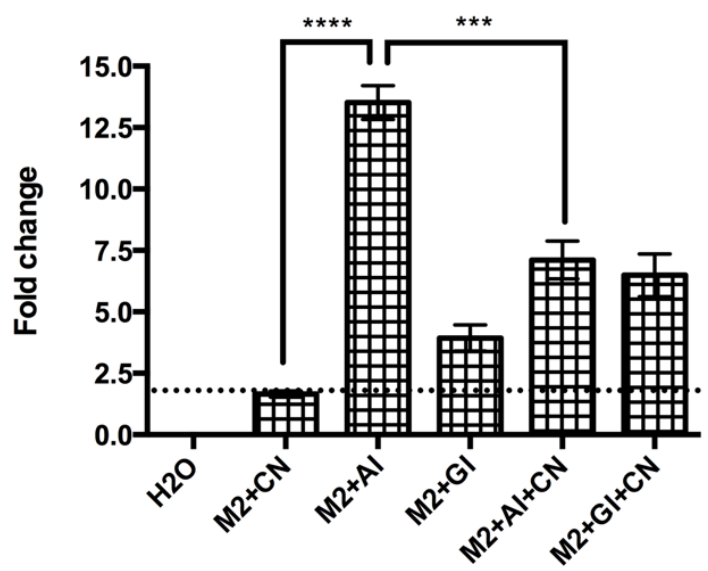

Tnfa
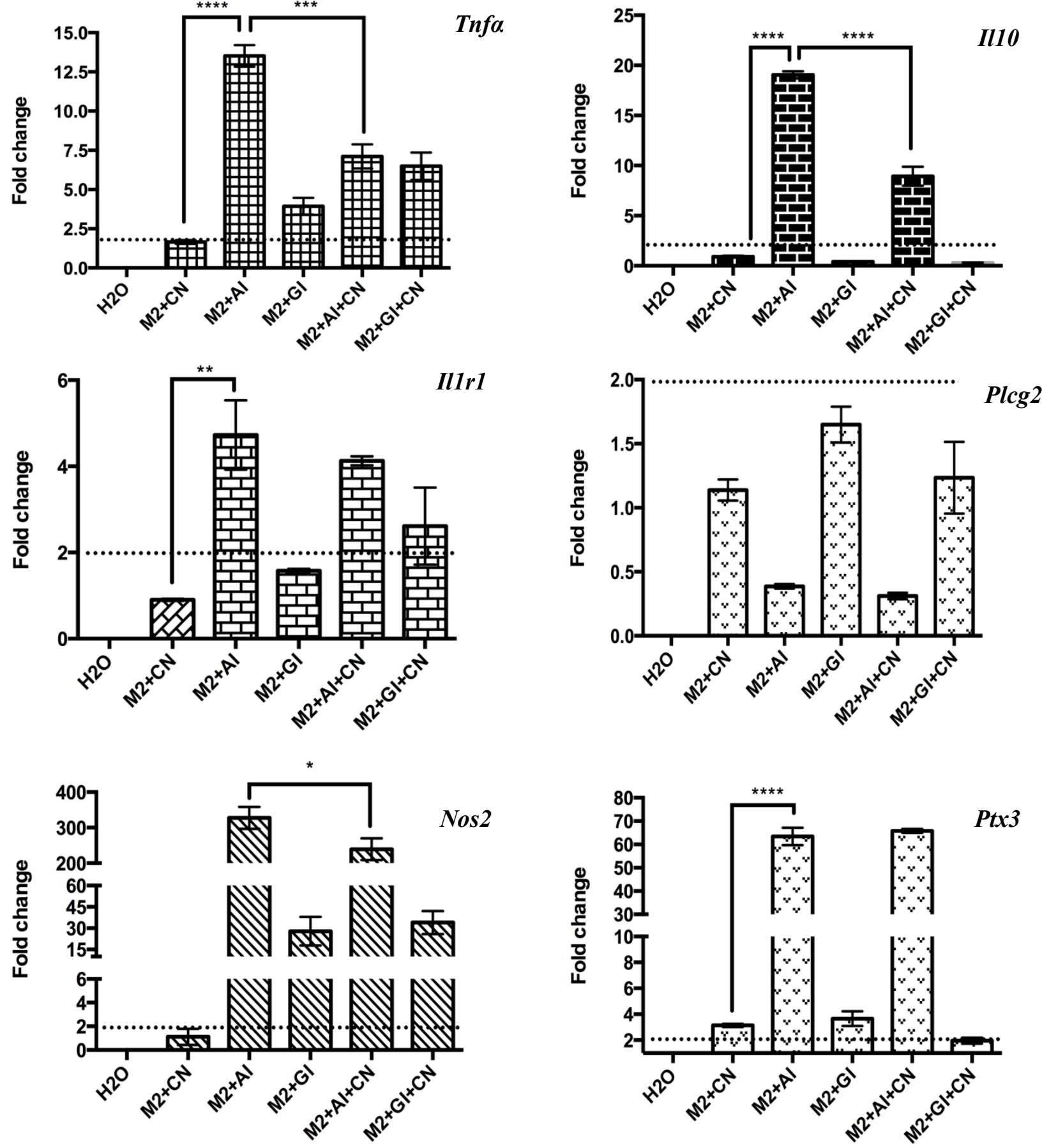

Figura 39. Comparação de expressão dos transcritos de genes relacionados à resposta imune de células M2

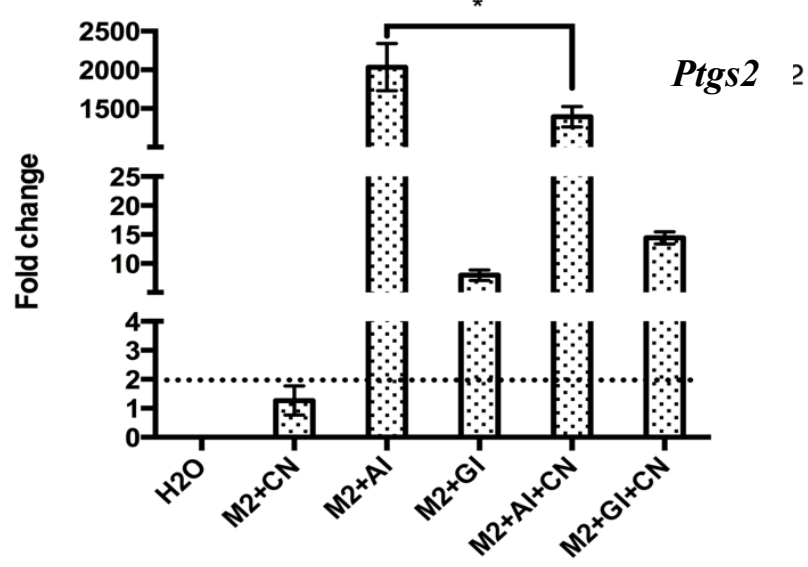
estimuladas com A. auricula e G. lucidum e infectadas com $\boldsymbol{C}$. neoformans. Os genes analisados codificam citocinas (TNF- $\alpha$, IL-10 e IL1R1), enzimas (PLCG2, PTGS2, iNOS) e da proteína PTX3. O tempo de estímulo dos polissacarídeos foi de 12 horas; Tempo de infecção após estímulo com polissacarídeos foi de 2 horas; GI Ganoderma fração insolúvel $100 \mu \mathrm{g} / \mathrm{mL}$; AI Auricularia auricula fração insolúvel $100 \mu \mathrm{g} / \mathrm{mL}$; M2 macrófagos alternativamente ativados; $\mathrm{O}$ "fold change" foi calculado pelo método $2^{-\Delta \Delta \mathrm{Ct}}$. Acima das linhas pretas pontilhadas significam expressão significativa, acima de 2. experimento realizado em triplicata biológica. $p$ significativo quando $<0,05$ 
Os resultados indicaram que houve uma expressão induzida dos transcritos de Tnfa, Il10, Illr, Nos2, Ptx3 e Ptgs2 (Figuras 38 e 39) em células M2 estimuladas com Auricularia auricula. Após duas horas de infecção com C. neformans a expressão induzida dos genes para Syk, Nfkb, Illrl e Ptx3 não diminuiu (Figuras 38 e 39). Contudo, 2 horas após infecção houve expressão induzida de $S y k$ e $N f k b$. Nas células estimuladas com frações de Ganoderma lucidum houve expressão induzida de Tnfa, Nos2 e Ptx3. Após duas horas de infecção houve expressão reprimida de Tnf $\alpha$ e Ptx3 e uma expressão induzida mantida para Nos2.

\section{Avaliação de curva de sobrevivência durante infecção com Cryptococcus neoformans} sob estímulo com os polissacarídeos de Auricularia auricula e Ganoderma lucidum.

Para avaliar a capacidade dos polissacarídeos de Auricularia auricula e Ganoderma lucidum auxiliarem na resposta imunitária durante o curso da infecção da criptococose in vivo, foi realizado o experimento de curva de sobrevida, administrando as frações dos cogumelos por via intranasal ou oral (Figuras 40 e 41).

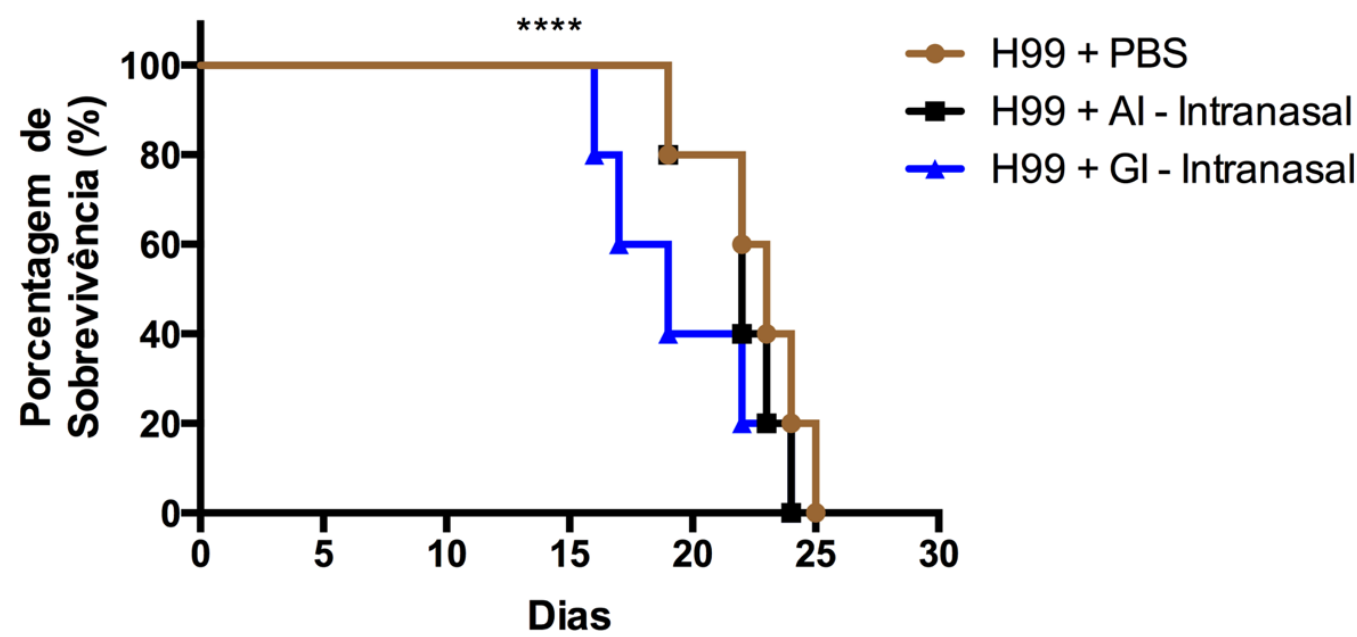

Figura 40. Efeito dos polissacarídeos de Auricularia auricula e Ganoderma lucidum administrados via intranasal no curso da doença de $\boldsymbol{C}$. neoformans in vivo. Animais ( $\mathrm{n}=5$ ) C57/BL/6 foram infectados com leveduras $C$. neoformans (H99) e após 3 dias de infecção foram tratados 3 vezes por semana por via intranasal com $25 \mu \mathrm{g}$ de polissacarídeos insolúveis de A. auricula e G. lucidum. Testes Log-Rank (MantelCox) e logrank for trend, $\mathrm{p}$ significativo quando $<0,05$. 


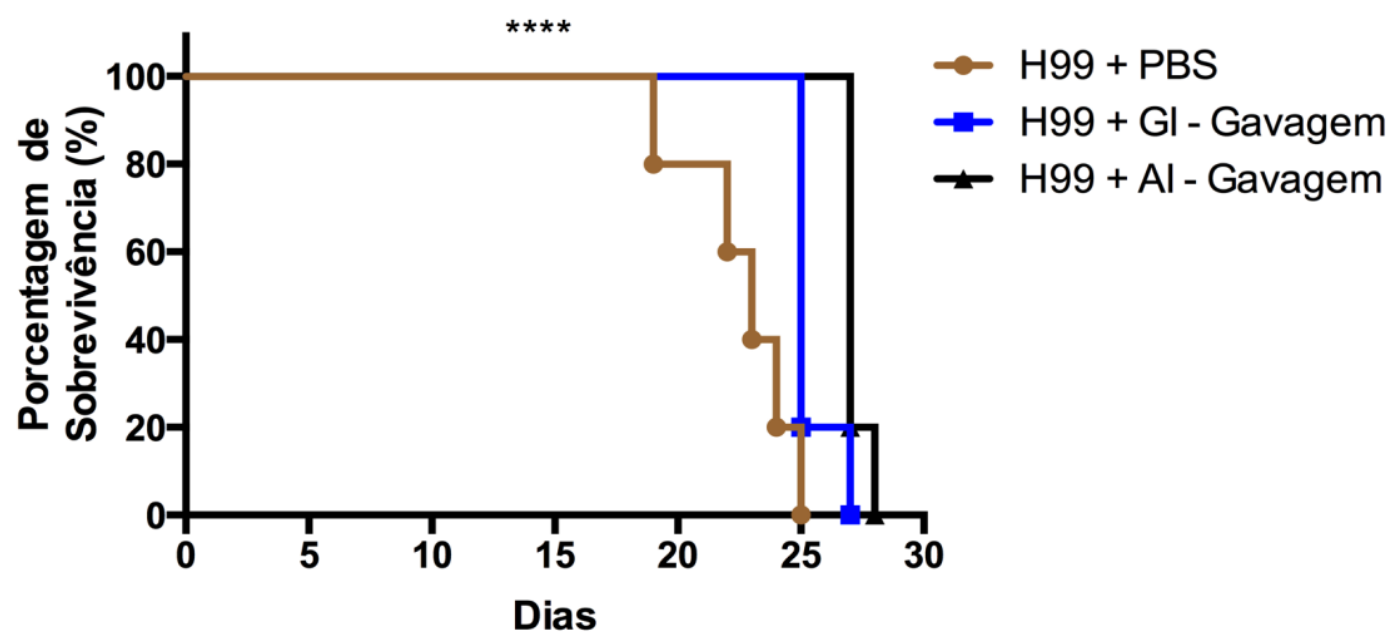

Figura 41. Efeito dos polissacarídeos de Auricularia auricula e Ganoderma lucidum administrados via oral no curso da doença de $\boldsymbol{C}$. neoformans in vivo. Animais (n=5) C57/BL/6 foram infectados com leveduras $C$. neoformans (H99) e após 3 dias de infecção foram tratados 3 vezes por semana por via intranasal com $25 \mu \mathrm{g} / \mathrm{mL}$ de polissacarídeos insolúveis de A. auricula e G. lucidum. Testes Log-Rank e Mantel-Cox e logrank for trend, p significativo quando $<0,05$.

O tratamento com a fração de Ganoderma lucidum por via intranasal diminuiu de forma significativa a sobrevida dos animais infectados, cuja mortalidade ocorreu entre o $16^{\circ}$ e o $24^{\circ}$ dia pós infecção, quando comparado aos animais infectados e tratados com PBS (mortalidade entre $19^{\circ}$ e $25^{\circ}$ dia pós infecção) (figura 40). Ademais, a fração de Auricularia auricula (mortalidade entre $19^{\circ}$ e $24^{\circ}$ dia pós infecção) não apresentou diferença significativa quando comparada ao controle PBS (figura 40), demonstrando que a diferença significativa entre os tratamentos, mesmo que não proporcionando sobrevida aos animais. Entretanto, os animais tratados com ambas as frações de cogumelos por via oral demonstraram um aumento expressivo na curva de sobrevida quando comparado com controle PBS (figura 41). Os animais tratados via oral com G. lucidum morreram entre o $27^{\circ}$ e $26^{\circ}$ dia pós infecção e os tratados com A. auricula morreram entre o $28^{\circ}$ e $29^{\circ}$ dia. 


\section{DISCUSSÃO}

A atuação de macrófagos e células dendríticas é crucial para a resposta à criptococose, uma vez que na ausência destas células a sobrevivência diminui drasticamente (Osterholzer et al., 2009b; revisado por Coelho et al., 2013). Neste contexto, a atividade fagocítica aumentada é extremamente relevante no combate a $C$. neoformans, o que foi observado neste trabalho em DCs e macrófagos estimulados com Auricularia auricula (figura 30) e também demonstrado por Xu et al. (2016) e Hui-Xin (2009) após utilizar a mesma espécie de cogumelo. Ademais, outros polissacarídeos extraídos de cogumelos comestíveis também causaram um aumento na atividade fagocítica aumentada, tais como Agaricus blazei (revisado de Martins, 2008b), Flammulina velutipes, Pleurotus ostreatus e Lentinula edodes (Yang et al. 2015). Entretanto, o cogumelo G. lucidum não aumentou a atividade fagocítica das células avaliadas neste trabalho, apesar de vários estudos demonstrarem a fagocitose após o estímulo com o cogumelo (Zhu et al., 2007; Xu et al., 2011; Hsu et al., 2012). O que poderia justificar essa diferença seria a forma de obtenção do polissacarídeo na interferência no mecanismo biológico. O reconhecimento, internalização e a fagocitose de leveduras de $C$. neoformans no pulmão ocorre após o reconhecimento de padrões moleculares associados a patógenos pelos receptores de fagocitose como receptores do sistema complemento 3, FcgR e dectina-1 (revisado em Coelho et al., 2013; Rohatgi e Pirofski, 2015). No entanto, o C. neoformans apresenta uma capsula que dificulta o processo de fagocitose. Neste ensaio utilizamos o anticorpo 18B7 para opsonizar o fungo e auxiliar no processo de fagocitose. Somente a interação dos FcgR com o anticorpo opsonizante é capaz de induzir a fagocitose das leveduras, no entanto, a estimulação das células por outros componentes, como os polissacarídeos, aumentou o processo de fagocitose. Neste contexto, a internalização foi maior quando comparada com as células não estimuladas e infectadas com o fungo opsonizado (controle) (Figura 30).

Após o processo de internalização, a destruição do fungo é importante para a resolução da doença. Leucócitos residentes do pulmão, como as células dendríticas primárias e macrófagos alveolares, são as primeiras células imunes expostas a $C$. neoformans sendo essenciais na resposta do hospedeiro. Assim, a sobrevivência de camundongos diminui drasticamente na ausência destas células (Osterholzer et al., 2009b; revisado em Coelho et al., 2013). Avaliando a resposta de células dendríticas 
estimuladas durante a infecção fúngica (Figura 31 e 32 ) observa-se que ambos os cogumelos aumentaram uma possível atividade microbicida, demonstrando uma resposta favorável ao hospedeiro. Os macrófagos classicamente e alternativamente ativados são observados nos modelos experimentais para avaliação da criptococose (Arora et al., 2011). A resposta a $C$. neoformans nos pulmões está correlacionada com a polarização dos macrófagos (Fan et al., 2005); enquanto macrófagos M1 e M2 estão associados à resposta Th1 e Th2, respectivamente. Contudo, mudanças microambientais podem influenciar na polarização de macrófagos (Rohatgi e Pirofski, 2015). Classicamente, os macrófagos M1 são células fungicidas mais eficientes do que macrófagos M2 (Hernandez et al., 2005; McQuiston e Williamson, 2012). Entretanto, após o estímulo com as frações de A. auricula macrófagos M2 foram mais eficientes quando comparados a M1 na cinética de infecção e na porcentagem de eliminação (Figuras 31 e 32). Para este resultado, a hipótese é de que os mecanismos microbicidas dos macrófagos M1 já estavam ativados e o estímulo com os polissacarídeos dos basidiomicetos não foi capaz de aumentar este processo de ativação microbicida enquanto que para os macrófagos M2, devido ao seu perfil menos inflamatório, foi possível modular o aumento dos mecanismos microbicidas. Deste modo, a atividade de macrófagos M2 são consideradas opostas àquelas de macrófagos M1 (Morris et al., 2011; Roszer, 2015). Contudo, os M2 apresentam uma alta capacidade fagocítica (Bohlson et al., 2014; Roszer, 2015) e de remoção de células apoptóticas, promovendo uma resposta imunológica mais equilibrada e favorecendo a cicatrização de tecidos (Sica e Mantovani, 2012; Ferrante e Leibovich, 2012; Roszer, 2015). Porém, além de estar envolvido em processos alérgicos e auxiliar no crescimento de tecidos tumorais, células M2 são consideradas um reservatório de vários patógenos (Sica e Mantovani, 2012). Durante a infecção por C. neoformans, macrófagos M2 não são normalmente utilizados para a replicação do fungo (Osterholzer et al., 2009a; Voelz et al., 2009) e se infectados auxiliam na disseminação (Chrétien et al., 2002; Charlier et al., 2009). Neste contexto, isso ocorre provavelmente devido ao fato do patógeno estimular a produção de arginase, gerando uma baixa produção de $\mathrm{NO}^{-}$por estes macrófagos (Davis et al., 2013). Neste contexto, o estímulo apropriado destas células fagocíticas pode auxiliar na resposta imune inata contra C. neoformans, uma vez que a polarização destes é um fator chave na defesa contra o fungo, bem como na determinação do controle e progressão da infecção. 
A ativação do sistema imune inato por $C$. neoformans desencadeia o aumento da atividade fungicida de macrófagos in vitro, principalmente quando dectina-1 é capaz de reconhece-lo e a partir deste reconhecimento, mediar a ativação do inflamassoma e da produção de citocinas pró inflamatórias, o que gera uma resposta antifúngica efetiva (revisado de Coelho et al., 2013). A resposta orquestrada por linfócitos Th1 à criptococose envolve a produção de várias citocinas, dentre elas TNF- $\alpha$ e IL-1 $\beta$ (Retini et al., 1996; Herring et a. 2002; Rohatgi e Pirofski, 2015). Contudo, relatos da literatura indicam que $C$. neoformans apresenta a capacidade de suprimir a produção de TNF- $\alpha$ em macrófagos (Zaragoza et al., 2009; Chabrier-Roselló, 2013). Considerando a possibilidade de intervenção nestes mecanismos de escape observado por C. neoformans, as frações insolúveis dos fungos avaliados neste trabalho podem ser utilizadas como um modulador positivo da atividade de macrófagos, o que foi observado em células dendríticas cuja secreção de TNF- $\alpha$ aumentou 24 horas após a infecção (Figura 33). Entretanto, a redução da produção de IL-1 $\beta$ em células infectadas não foi revertida em DCs e macrófagos M1 e M2 (figura 34). A redução na produção de IL-1 $\beta$ por $C$. neoformans foi relatada anteriormente na literatura (Zaragoza et al., 2009). Neste ensaio foram usados os controles positivos LPS (agonista de TLR4), zimosan depletado (agonista de dectina-1) e Pam3CSK4 (agonista de TLR2). Estes agonistas são ativadores clássicos de citocinas pró-inflamatórias além de serem essenciais para a ativação de células importantes na proteção do hospedeiro pela indução de uma resposta imune adaptativa efetora. Estes agonistas demonstraram influenciar distintamente na função antimicrobiana, produzindo níveis distintos de citocinas e da capacidade fungicida (Gil e Gozalbo, 2009; Megias et al., 2016). No combate às doenças que cursam com depressão da imunidade do hospedeiro estão as novas abordagens utilizando ligantes (agonistas ou antagonistas), que interagem com seu respectivo receptor e modulam a atividade das células alvo. As vantagens desta estratégia seriam não causar a resistência do sistema imune, apresentar uma natureza rápida e gerar uma proteção ampla, permitindo a utilização combinada de agentes antimicrobianos e vacinas (Mifsud et al., 2014).

A molécula óxido nítrico é sintetizada por vários tipos de células em diversos tecidos e está envolvida em respostas fisiológicas e patológicas múltiplas, podendo ser ativada por estímulos do sistema imunológico, tais como IFN- $\gamma$, TNF- $\alpha$ e LPS (Moncada e Higgs, 1993; Bogdan et al., 2000; revisado de Mao et al., 2013). Avaliando os níveis de $\mathrm{NO}^{-}$in vitro, os polissacarídeos de Ganoderma lucidum, Pam 3 , LPS e zimosan 
depletado estimularam uma produção menor que $10 \mu \mathrm{M}$ (Figura 35), valores semelhantes aos descritos na literatura (Yao et al., 2004; Woo et al., 2005; Tsolmongyn et al., 2013). Ademais, Agaricus blazei e G. lucidum não apresentaram a capacidade de produzir NOem macrófagos (Woo et al., 2005; revisado de Martins, 2008b), diferentemente de Grifola frondosa (Sanzen et al., 2001) e A. auricula (figura 35). No tempo de 12 horas após estímulo, Auricularia auricula apresentou níveis de $\mathrm{NO}^{-}$de $32 \mu \mathrm{M}$ (M1) e $26 \mu \mathrm{M}$ (M2). As células dendríticas produziram nível menor, $22 \mu \mathrm{M}$ (Figura 35). Segundo Acharya et al. (2004), os polissacarídeos de Auricularia auricula estimularam uma produção de $\mathrm{NO}^{-}$ dependente do estímulo mesmo quando se utilizou o inibidor de L-arginina.

Estudos prévios demonstram que os metais ferro e cobre são importantes na virulência de $C$. neoformans, atuando na síntese de melanina, na captação de ferro e na detoxificação de espécies reativas de oxigênio. Relatos da literatura revelaram que $C$. neoformans foi capaz de inibir a produção de espécies reativas de oxigênio (EROS) (Walton et al., 2005; Jung et al., 2006; Jung et al., 2009; revisdo de Ding et al., 2013) e óxido nítrico (Naslund et al, 1995, Zaragoza et al., 2009; Chabrier-Roselló et al., 2013), o que implica na necessidade de uma avaliação inibitória direta a $C$. neoformans após estímulo com polissacarídeos de A. auricula e G. lucidum na produção de EROs (figura 36). Os resultados evidenciaram que os macrófagos M2 apresentaram um perfil distinto de produção de EROs após estímulo, uma vez que a fração de A. auricula estimulou a produção. Por outro lado a fração de G. lucidum além de não estimular inibiu a produção (Figura 36). Alguns relatos da literatura indicam que as frações de G. lucidum é capaz de inibir a produção de EROS (Hsu et al., 2004; Zhong et al., 2015), o que poderia explicar o resultado da figura 36. Após 2 horas de infecção os níveis de $\mathrm{NO}^{-}$foram reavaliados e os macrófagos M2 estimulados monstraram uma redução na produção de EROs. A cápsula de C. neoformans visa a proteção do patógeno de mecanismos efetores do sistema imune, assim como na inibição da ação de espécies reativas de nitrogênio e oxigênio em macrófagos (Zaragoza, 2011; O'Meara e Alspaugh, 2012); o que pode explicar o resultado observado no tempo de 2 horas pós infecção, cujos níveis diminuíram consideravelmente. Entretanto, os níveis permaneceram significativamente maiores quando comparado ao controle (zimosan não depletado) o que poderia indicar um nível residual importante para a resposta imune inata efetora contra $C$. neoformans. Posteriormente, será realizada uma avaliação no tempo de 24 horas será feita. 
Para confirmar a ativação das células avaliadas neste trabalho, os níveis de transcritos gênicos envolvidos na resposta imune contra $C$. neoformans de macrófagos M2 estimulados foram avaliados antes e após a infecção, como Syk, Nfkb, Illrl (gene codificador do receptor da interleucina 1 tipo 1), Tnfa, Illo e Nos2 (gene codificador da enzima óxido nítrico sintase, iNOS) (Figuras 38 e 39). Os resultados obtidos corroboraram com as avaliações anteriores, pois ocorreu a detecção de $\mathrm{NO}^{-}$, das citocinas TNF- $\alpha$ e IL-10, bem como foi demonstrado a participação da molécula adaptadora Syk e do fator de transcrição NF-kB após o estímulo das frações insolúveis dos cogumelos. Alguns genes não demonstraram uma regulação positiva ou negativa, caso dos receptores Mrcl e Tlr9, bem como de Plcg2 (gene codificador da enzima fosfolipase C gama 2, PLCG2) e de Stat1 (Figuras 38 e 39). Além disso, após 2 horas de infecção o fungo $C$. neoformans modulou negativamente a expressão dos genes Tnfa, Illo, Il1r1, Nos2 e Ptgs2, que foram regulados positivamente pelo estimulo prévio da fração insolúvel de $A$. auricula. Segundo Zaragoza et al. (2009) C. neoformans consegue modular a secreção das citocinas pró-inflamatórias TNF- $\alpha$ e Il-1 $\beta$, o que poderia explicar a diminuição dos níveis destes transcritos após a infecção (Figuras 38 e 39).

Os níveis elevados de transcritos de Ptx3 e Ptgs 2 destacaram-se dos demais genes avaliados. A proteína PTX3 faz parte de uma superfamília de proteínas multifuncionais, cuja ativação da expressão apresenta atividade de acordo com seus ativadores: (1) um efeito pró-inflamatório quando há a produção das citocinas TNF- $\alpha$ e IL-1 $\beta$ e (2) um efeito anti-inflamatório induzido pelo receptor lisosfingolipideo 1 (SP1) e da lipoproteína de alta densidade 3 (HDL3) (Kunes et al., 2012). Ademais, devido à complexidade das reações inflamatórias, mais de um estímulo é necessário para a produção de PTX3, podendo ser estimulado por agonistas do receptor TLR (LPS), microrganismos intactos (C. neoformans) (Polentarutti et al., 2000) ou particulados (lipoarabinomananas) (Kunes et al., 2012), o que poderia justificar o aumento dos níveis de transcrito de PTX3 estimulado por A. auricula (com níveis altos também após infecção) e G. lucidum (Figura 39). A expressão de PTX3 também pode ser regulada negativamente em células dendríticas e macrófagos com a participação do hormônio glicocorticoide (Doni et al., 2008), IL-4, calcitriol ( $\alpha$,25-dihidroxivitamina D3), prostaglandina E2 e IL-10 (Damazo et al., 2006; Kunes et al., 2012). Após estímulo, macrófagos M2 aumentaram os níveis de PTGS2 (ambos os cogumelos) e IL-10 (A. auricula), sugerindo um possível equilíbrio na resposta imune inata após estímulo com os cogumelos estudados neste trabalho (Figura 
39). No epitélio pulmonar a indução da produção de PTX3 está associada à resposta inflamatória aguda, principalmente pela presença de TNF- $\alpha$, e uma vez produzido favorece a opsonização de patógenos fúngicos como Paracoccidioides brasiliensis e Aspergillus fumigatus (Garianda et al., 2002; Brown, 2006; Bozza et al., 2014).

As enzimas ciclooxigenase 1 e 2 são codificadas pelos genes PTGS1 (constitutivo) e PTGS2 (estimulado), que catalisam a síntese do ácido graxo eicosanoide prostaglandina, um regulador chave da inflamação (Vogel et al., 2014). Em relação a PTGS2, o estímulo que desencadeia a produção pode ser devido à agonistas de receptores TLR, citocinas pró-inflamatórias e de PAMPs fúngicos (Rodríguez et al., 2014). A atividade de prostaglandina E2 pode ser considerada dúbia, devido à sua capacidade próinflamatória (promover vasodilatação, edema e migração/ativação de leucócitos) e imunomoduladora (indução da produção de IL-10 e diminuição da secreção de interleucina 12 subunidade p70 - (IL-12p70), porém isto pode ser explicada devido a ações distintas em tipos celulares diferentes. Nos pulmões, sítio primário de infecção de C. neoformans, a prostaglandina atua como um anti-inflamatório (Mezger et al., 2008), o que é interessante para células estimuladas com frações de A. auricula (Figura 39), uma vez que poderia gerar um balanço no processo inflamatório causado pela criptococose. A capacidade de produzir prostaglandina em resposta a PAMPs está associada á origem, ao tipo de macrófago e o receptor envolvido (Rodríguez et al., 2014). Os estudos que procuram correlacionar o estado fenotípico de macrófagos com a liberação de ecoisanoides demonstraram predominantemente a produção de prostaglandina E2 e D2 além de um padrão variável de resposta dependente da presença de moléculas coestimulatórias, como fatores de crescimento (fator estimulador de colônias de granulócitos e de macrófagos - GM-CSF e fator estimulador de colônia de macrófagos C-CSF). Estes interferem na expressão de receptores, tais como dectina-1 (Rosas et al., 2008; Municio et al. 2013), que reconheceram as beta-glucanas presentes nos compostos avaliados neste trabalho (Figuras 23 e 24) e justifica o aumento expressivo de transcritos após os estímulos de ambos os cogumelos (Figura 39). Entretanto, Valdez et al. (2012) demonstraram que a produção de prostaglandina E2 foi responsável por suprimir a atividade antifúngica da imunidade inata em modelos murinos infectados com $C$. neoformans. Ademais, os níveis de transcritos de PTGS2 aumentaram após a infecção por Candida albicans (Filler et al., 1996; Naglik et al., 2014) e Aspergillus fumigatus (Mezger et al., 2008), o que corrobora com o resultado de Valdez e et al. (2012). 
Um dos adjuvantes mais utilizados para a composição de vacinas é o hidróxido de alumínio. Alguns estudos demonstraram que as beta-glucanas podem ser utilizados em plataforma de vacinas, combinando adjuvantes e antígenos (Huang et al., 2013b; Berner et al., 2015; Wilber et al., 2016; Soto et al., 2016). Outros estudos serão realizados visando avaliar se os polissacarídeos utilizados neste trabalho podem ser empregados como adjuvantes.

Para diversos metabólitos oriundos de cogumelos descritos anteriormente, são necessários estudos para determinar se os benefícios demonstrados in vivo são comparáveis aos efeitos in vitro reportados (Lull et al., 2005). Após os resultados anteriores in vitro envolvendo o estímulo prévio de polissacarídeos e a resposta imune inata ao fungo $C$. neoformans, a avaliação in vivo foi feita pela curva de sobrevida em camundongos. A capacidade de alguns metabólitos no aumento ou supressão da resposta imune depende de vários fatores como a dose, a rota e o tempo de administração do composto avaliado. O tipo de atividade demonstrado por metabólitos depende do seu mecanismo de ação ou do sítio de atividade biológica (Lull et al., 2005), o que foi evidenciado utilizando diferentes vias de administração, intranasal e oral (figuras 40 e 41 respectivamente). A resposta distinta e o prolongamento ou não do tempo de sobrevivência dos animais demonstrado nas diferentes vias de tratamentos possivelmente se devem a dois fatos: (1) a administração por via intranasal em um local previamente inflamado pela resposta contra $C$. neoformans, que culminou em uma inflamação potencializada desfavorável ao hospedeiro diminuindo a capacidade de sobrevida (Figura 40); (2) a administração por via oral, envolvendo a interação do sistema imune e da microbiota do trato gastrointestinal, que prolongou a sobrevida dos animais infectados (Figura 41).

Os efeitos de probióticos de polissacarídeos de cogumelos comestíveis são descritos na literatura, o que corrobora com o resultado da figura 41, uma vez que enzimas digestivas humanas são capazes de hidrolisar $\beta$-glucanas e assim os polissacarídeos podem atuar como uma fonte (Aida et al., 2009) de crescimento de vários microorganismos como Lactobaccilus, Bifidibacterium e Enterococcus. O aumento dos microorganismos alvos citados foi observado anteriormente após o consumo dos cogumelos comestíveis Pleurotus ostreatus e Pleurotus eryngii (Synytsya et al., 2009), sendo ainda reportado o efeito protetivo de bactérias probióticas estimuladas no suco gástrico e da bile após consumo de cogumelos (Giavasis, 2014). Os micro-organismos probióticos com 
habilidade modulatória podem ser denominados como imunobióticos (Villena et al. 2016; Kobayashi et al., 2017). Atualmente, está sendo realizados estudos referente a capacidade de treinar ("training") e potencializar a resposta do sistema imune após estímulos, juntamente à participação da microbiota, é atualmente investigada. Rizzetto et al. (2016) demonstraram a capacidade do "training" de polissacarídeos de S. cerevisiae em monócitos, que aumentaram a produção de TNF- $\alpha$ e IL-6, bem como a população de bactérias e fungos comensais. Ademais, a composição da parede celular de determinados agonistas podem influenciar no "training” de células imunológicas (Rizzetto et al., 2016). A administração recorrente (três vezes por semana) de polissacarídeos dos cogumelos por via oral (Figura 41), pode ter proporcionado um "training" da imunidade inata, bem como ter contribuído para o aumento da sobrevida dos animais infectados. Porém, são necessários outros estudos são necessários para confirmar esta hipótese. $\mathrm{O}$ receptor dectina-1 foi correlacionado à homeostasia da imunidade intestinal, por meio da diferenciação de células T regulatórias (Tang et al., 2015). Os polissacarídeos estudados neste trabalho foram reconhecidos por dectina-1 e desencadearam uma sinalização intracelular (Figuras 23 e 24), sugerindo que contribuam a regulação da população da microbiota. Estudos estão em andamento para avaliar se os polissacarídeos estudados neste trabalho favorecem ou não diretamente a microbiota, assim como a sua interação com o sistema imune.

Portanto, neste capítulo conclui-se que a fração insolúvel de A. auricula é promissora nos estudos da infecção da criptococose, uma vez que estimula os principais mecanismos imunes relacionados à defesa inata contra o fungo patogênico $C$. neoformans.

\section{CONCLUSÃO}

Os resultados apresentados neste trabalho indicaram que ambos os cogumelos apresentam atividade imunomodulatória. Porém, conclui-se que os polissacarídeos de $A$. auricula demonstraram uma atividade biológica mais efetiva na ativação de macrófagos, como demonstrado no modelo esquemático (Figura 42) sendo assim mais promissores nos estudos referentes ao aumento da imunidade inata frente ao fungo patogênico $C$. neoformans. 


\section{MODELO PROPOSTO}
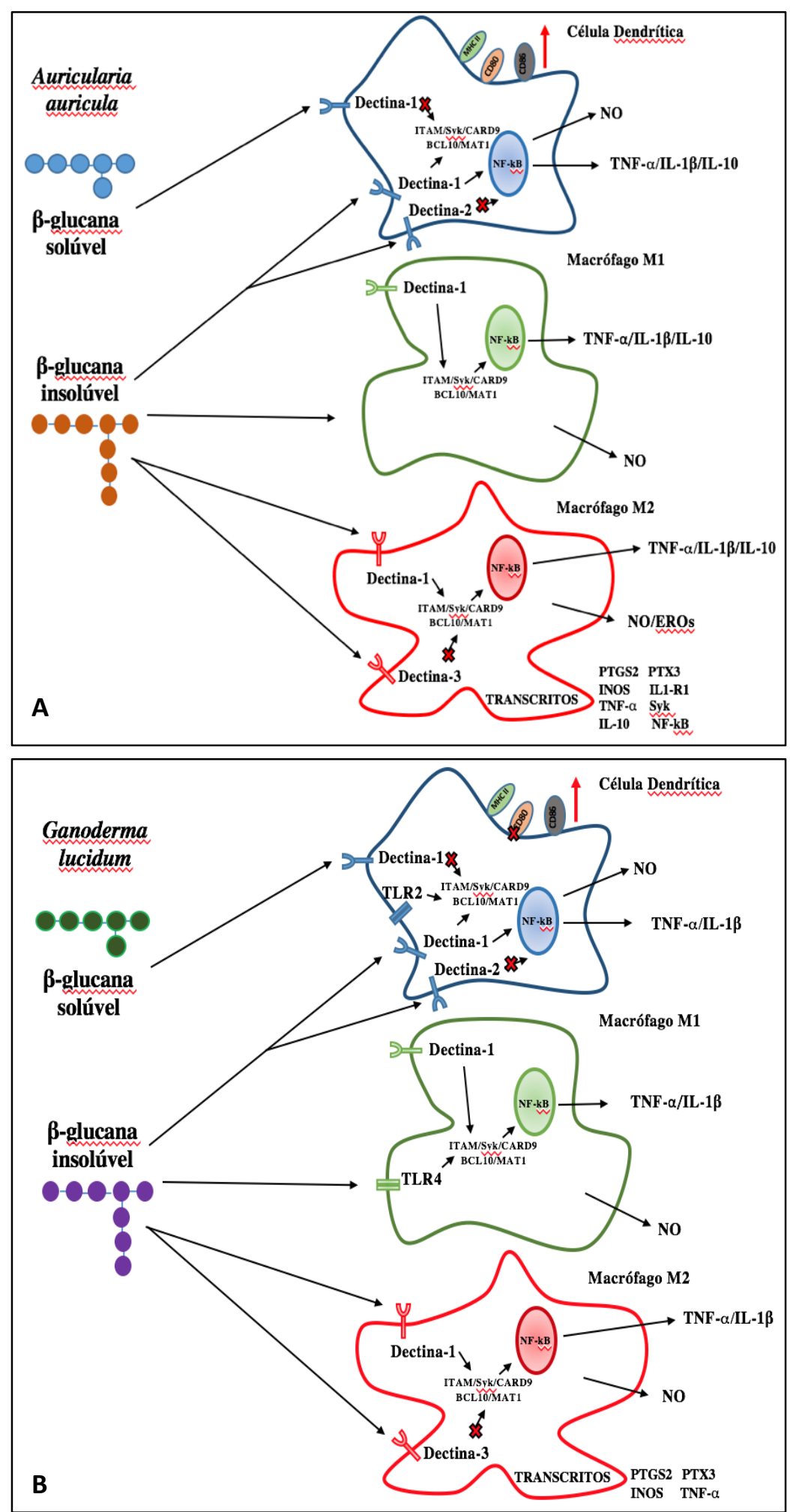

Figura 42. Modelo esquemático da sinalização de beta glucanas das frações dos cogumelos A. auricula (A) e $G$. lucidum (B) em células da imunidade inata. Apenas as frações insolúveis ligaram-se ao receptor dectina-1 $(A$. auricula), TLR2 e TLR4 ( $G$. lucidum) e desencadearam a jusante a transdução de sinal, com a participação da molécula adaptadora Syk e a ativação do fator de transcrição NF-kB. A ativação de NF-kB resultou na secreção das citocinas TNF- $\alpha$, IL-1 $\beta$ e IL-10 por DC, M1 e M2, bem como na produção de $\mathrm{NO}^{-}$, EROs e dos transcritos dos genes Ptgs2, Ptx3, Inos, Tnfo, Il10, Illr1, Syk, Nfkb em células M2 estimuladas. Houve aumento nos níveis das moléculas co-estimulatórias CD80, CD86 e MHCII em DCs estimuladas com as frações insolúveis de Auricularia auricula e aumento de CD86 e MHCII para DCs estimuladas com frações insolúveis de $G$. lucidum. DC - células dendríticas; M1 - macrófagos classicamente ativados; M2 macrófagos alternativamente ativados; $\mathrm{NO}^{-}$- óxido nítrico; EROs - espécies reativas de oxigênio, TNF- $\alpha$ - fator de necrose tumoral alfa; IL-1 $\beta$ interleucina 1 beta; IL-10 interleucina 10; Ptgs $2 \quad-$ prostaglandina E2; Ptx3 Pentraxina 3; Inos - óxido nítrico sintase; Illrl - receptor tipo 1 da interleucina 1 . 


\section{PERSPECTIVAS}

Como perspectivas deste trabalho:

- Avaliar a estrutura das frações de Ganoderma lucidum utilizando a técnica de ressonância magnética nuclear.

- Avaliar os estímulos de G. lucidum e A. auricula na acidificação do fagolisossomo antes e após infecção in vitro com C. neoformans in vitro.

- Avaliar a interação da microbiota com o sistema imune após o estímulo dos polissacarídeos de A. auricula e G. lucidum, analisando detalhadamente a população comensal durante essa interação.

- Avaliar a capacidade dos polissacarídeos no "training” de células imunológicas.

- Avaliar a resposta inflamatória e a carga fúngica nos pulmões após o tratamento por via oral e nasal em camundongos.

- Estudar a influência dos polissacarídeos de A. auricula e G. lucidum na imunidade adaptativa. 


\section{REFERÊNCIAS}

Abbas, A.K., Murphy, K.M. e Sher, A. Functional diversity of helper T lymphocytes. Nature, v.383,p.787-93. 1996.

Abbas, A.K., Lichman, A.H. e Pillai, S. Imunologia celular e molecular. $8^{\circ}$ edição. Editora Elsevier. 592p. Rio de Janeiro- RJ. 2015.

Acharya, K. et al. Antioxidant and nitric oxide synthase activation properties of Auricularia auricula. Indian Journal of Experimental Biology, v.42,n.5,p.538-40. 2004.

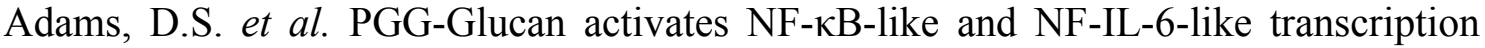
factor complexes in a murine monocyte cell line. Journal of Leukocyte Biology, v.62,p.865-873. 1997.

Aida, F.M.et al. Mushroom as a potential source of prebiotics: a review. Trends Food Science Technology, v.20,p.567-575. 2009.

Ali, S.H. The world of $\beta$-glucans - a review of biological roles, applications and potential areas of research. Mestre (Ciência - Biologia Médica). 45f. Instituto de Biologia Médica, Faculdade de Medicina, Universidade de Tromso, Noruega. 2009.

Almeida, F., Wolf, J.M., Casadevall, A. Virulence-associated enzymes of Cryptococcus neoformans. Eukaryotic Cell, v.14, n.12,p.1173-85. 2015.

Antachopoulos, C. e Walsh, T.J. Immunotherapy of Cryptococcus infections. Clinical Microbiology and Infection, v.18,n.2,p.126-133. 2012.

Arendrup, M.C. et al. Diagnostic issues, clinical characteristics, and outcomes for patients with fungemia. Journal of Clinical Microbiology, v.49,n.9,p.9. 2011.

Arora S. et al. Effect of cytokine interplay on macrophage polarization during chronic pulmonary infection with Cryptococcus neoformans. Infection and Immunity. v.79,n.5,p.1915-26. 2011.

Aspinall G.O. The polysaccharides. New York: academic Press. 1982; 1-2:340 e 503. 1982.

Bacic A et al. Structure and function of plant cell walls. In: Stumpf, PK, Conn EE (EDs), The Biochemistry of Plants academic Press. New York. p.297-371. 1998.

Bahn, Y.S. et al. Sensing the environment: lessons from fungi. Nature Reviews Microbiology, v.5,p.57-69. 2007.

Balloy, V. e Chignard, M. The innate immune response to Aspergillus fumigatus. Microbes and Infection, v.11,n.12,p.919-27. 2009. 
Barbosa, F.M. et al. Glucuronoxylomannan-mediated interaction of Cryptococcus neoformans with human alveolar cells results in fungal internalization and host cell damage. Microbes Infection, v.8,p.493-502. 2006.

Barnett, J.A. A history of research on yeasts 14: medical part 2, Cryptococcus neoformans. Yeast, v.27,n.11,p.875-904. 2010.

Barnett, J.A. e Barnett, L. Yeast research: a historical overview. 1 ed. Editora ASM Press, Washinton - DC. 2011.

Barros, A.L.N. Análise functional do gene VELB de Cryptococcus neoformans. Dissertação (Mestre em Ciências e Tecnologia em Saúde). 114 f. Universidade de Brasília - UnB. 2014.

Bartnicki-Garcia S. Cell wall chemistry, morphogenesis, and taxonomy off Fungi. Annual Review of Microbiology, v.22,p.87-108. 1968.

Baskar, G. et al., Statistical optimization of polysaccharide production by submerged cultivation of Lingzhi or Reishi medicinal mushroom, Ganoderma lucidum (W.Curt.:FR) P.Karst. MTCC 1039 (Aphyllophoromycetideae). International Journal of Medicinal Mushroom, v.13,n.1,p.41-49. 2011.

Battle, J. et al. Ligand binding to the $(1 \rightarrow 3)-\beta$-D-glucan receptor stimulates NFkB activation, but not apoptosis in U937 cells. Biochemical and Biophysical Research Communications, v.249,p.499-504. 1998.

Batbayar, S., Kim, M.J. e Kim, H.W. Medicinal mushroom Lingzhi or Reishi, Ganoderma lucidum (W.Curt.:Fr.) P. Karst., beta-glucan induces Toll-like receptors and fails to induce inflammatory cytokines in NF-kappaB inhibitor-treated macrophages. International Journal of Medicinal Mushroom, v.13,n.3,p.213-25. 2011.

Bell, J.E. et al. The Impacts of climate change on human health in the United States: A scientific assessment. Cap. 4: Impacts of extreme events on human health. Fungal diseases and change Climate. U.S. Global Change Research Program. p.99-128. 2016. Disponível em: < https://health2016.globalchange.gov/extreme-events $>$

Benzie, I.F.F. e Wachtel-Galor, S. Herbal Medicine: Biomolecular and Clinical Aspects. 2 ed. Taylor e Francis Group. p.175-197. 2011.

Berovic, M. et al. Submerged cultivation of G. lucidum biomass and immunostimulatory effects of fungal polysaccharides. Journal of Biotechnology, v.103,p.77-86. 2003.

Berner, V.K. et al. Microparticulate $\beta$-glucan vaccine conjugates phagocytized by dendritic cells activate both naïve CD4 and CD8 T cells in vitro. Cellular Immunology, v.298,n.1-2,p.104-14. 2015.

Bett, C. F. e Perondi M.A. Análise do Mercado de cogumelos comestíveis e medicinais: uma prospecção de alternativa de renda para a agricultura familiar na região sudoeste do Paraná. Synergismus scyentifica, v.06, n.01. 2011. 
Beutler, B. Innate immunity: An overview. Molecular Immunology, v.40,p.845-859. 2004.

Beyer, D (2008) Mushroom substrate preparation odor management plan. Disponível em $<$ http://extension.psu.edu/publications/x10082 $>$ Acessado em: 12 de Maio de 2015.

Bitencourt, E.L. Prospecção química de carboidratos isolados dos basidiomas das linhagens branca e cinza do cogumelo medicinal Grifola frondosa ("Maitake"). 2015. 119 f. Dissertação de Mestrado (Mestre em Química) Universidade de Goiás - UFG, Regional Catalão.

Bode, J.G., Ehlting, C. e Haussinger, D. The macrophage response towards LPS and its control through the p38(MAPK)-STAT3 axis. Cellular Signalling, v.24,p.1185-1194. 2012.

Bogdan, C., Röllinghoff, M. e Diefenbach, A. The role of nitric oxide in innate immunity. Immunological Reviews, v.173,p.17-26. 2000.

Boh, B. et al. G. lucidum and its pharmaceutically active compounds. Biotechnology Annual Review, v.13,p.265-301. 2007.

Boh B. G. lucidum: A potential for biotechnological production of anti-cancer and immunomodulatory drugs. Recent Patents on Anticancer Drug Discovery, v.8,n.3,p.255-87. 2013.

Bohlson, S.S. et al. Complement, C1q, and C1q-related molecules regulate macrophage polarization. Frontiers in Immunology, vol. 5, article 402, 2014.

Boon, J.K. Netherlands losing ground in fresh mushroom trade. Fruit and Vegetables Facts. Disponível em: http://www.freshplaza.com/2015/0724/Factsheet $\% 20$ CHAMPIGNONS $\% 20$ Primeur $\% 2$ 0-\%20Jan\%20Kees\%20Boon_EnglishFP.pdf. Acessado em: 01.09.2016.

Borchers, A.T., Keen, C.L. e Gershwin, M.E. Mushrooms, tumors, and immunity: an update. Experimental Biology and Medicine, v.229,n.5,p.393-406. 2004.

Bortoli, K. Avaliação da produção de polissacarídeos extracelulares por Lentinula edodes e Ganoderma lucidum em diferentes néctares de fruta. Graduação (Bacharel em Engenharia de Alimentos) 33f. Universidade Federal do Paraná - UFPR. 2015.

Bovers, M.; Hagen, F.; Boekhout, T. Diversity of the Cryptococcus neoformansCryptococcus gattii species complex. Revista Iberoamericana de Micologia, v.25p.S412. 2008.

Bozza, S. et al. PTX3 binds MD-2 ad promotes TRIF-dependent immune protection in aspergillosis. The Journal of Immunology, v.193,n.5p.2340-2348. 2014.

Brown G.D., et al. Dectin-1 is a major beta-glucan receptor on macrophages. The Journal of Experimental Medicine, v.196,n.3,p.407-12. 2002. 
Brown, G. D. et al. Dectin-1 mediates the biological effects of $\beta$-glucan. The Journal of Experimental Medicine, v.197,p.1119-1124. 2003.

Brown, G.D. Dectin-1: A signaling non TLR pattern-recognition receptor. Nature Reviews Immunology, v.6,n.1, p.33-43. 2006.

Brown, G.D. et al. Hidden Killers: Human Fungal Infections. Science Translational Medicine, v.4,n.165.:165rv13. 2012.

Buchanan, P.K. A taxonomic overview of the genus Ganoderma with special reference to species of medicinal and neutraceutical importance. Proceedings of the International Symposium Ganoderma Science, Aukland, 27-29. 2001.

Calil, I.L. et al. Lipopolysaccharide induces inflammatory hyperalgesia triggering a TLR4/MyD88-dependent cytokine cascade in the mice paw. PloS One, v.9: e90013. 2014.

Calugaru, A. et al. Recognition and modulation of Dectin-1 and TLR-2 receptors by curdlan derivatives and purified natural extracts. Roumanian Archives of Microbiology and Immunology, v.68,n.3,p.119-24. 2009.

Carbonero, E.R. et al. Chemical and biological properties of a highly branched B-glucan from edible mushroom Pleurotus sajor-caju. Carbohydrate polymers, v.90,p.814-819. 2012.

Carlile, M.J.; Watkinson, S.C.; Gooday, G.W. The Fungi. 2 ed. London: Academic Press, p.587. 2001.

Casadevall, A et al. Antibodies elicited by a Cryptococcus neoformans-tetanus toxoid conjugate vaccine have the same specificity as those elicited in infection. Journal of Infectious Diseases, v.165,n.6,p.1086-93. 1992.

Casadevall, A. et al. Characterization of a murine monoclonal antibody to Cryptococcus neoformans polysaccharide that is a candidate for human therapeutic studies. Antimicrobial Agents Chemotherapy, v.42,n.6,p.1437-46. 1998.

Casadevall, A. et al. Vesicular transport across the fungal cell wall. Trends in Microbiology, v.17,p.158-62. 2009.

Casadevall, A. e Pirofski, L.A. Antibody-mediated protection through crossreactivityintroduces a fungal heresy into immunological dogma. Infection and Immunity, v.75,n.1,p.5074-8. 2007.

Casadevall, A. e Pirofski, L.A. Immunoglobulins in defense, pathogenesis, and therapy of fungal diseases. Cell Host \& Microbe, v.11,n.5,p.447-56. 2012.

Chabrier-Roselló, Y. et al. Cryptococcus neoformans phosphoinositide-dependent kinase 1 (PDK1) ortholog is required for stress tolerance and survival in murine phagocytes.

Eukaryotic Cell, v.13,n.1,p.12-22. 2013. 
Chan, F.K.M. Moriwaki, K. e Rosa, M.J. detection of necrosis by release of lactate dehydrogenase (LDH) activity. Methods in Molecular Biology, v.979,p.65-70. 2013.

Chan, G.C.F., Chan, W.K., Sze, D.M.Y. The effects of $\beta$-glucan on human immune and cancer cells. Journal of Hematology \& Oncology, v.2,n.25,p.1-11. 2009.

Chandler, F. e Watts, J. Micotic, actinomycotic, and algal infections. In Kissane, J. Anderson's Pathology. 9 ed. Editora C.V. Mosby, St. Loius, p. 391:432. 1996.

Chang, S.T.; Miles, G. Mushrooms. Cultivation, nutritional value, medicinal effect, and environmental impact. 2 ed. Ed. CRC Press. 2004.

Charlier C. et al. Evidence of a role for monocytes in dissemination and brain invasion by Cryptococcus neoformans. Infection and. Immunity, v.77,p.120-127. 2009.

Chen, J.Z. e Seviour, R. Medicinal importance of fungal $\beta-(1 \rightarrow 3,(1 \rightarrow 6)$-glucans. Mycological Research, v.111, p.635-652. 2007.

Chen, S. et al. Epidemiology and host- and variety-dependent characteristics of infection due to Cryptococcus neoformans in Australia and New Zealand. Australasian Cryptococcal Study Group. Clinical Infectious Diseases, v.31: 499-508. 2000.

Cheung, P.C.K. e Ooi, V.E.C. Antitumor and immunomodulatory activities of mushroom polysaccharides. Mushroom and Funcional Foods, cap. 5,p.147-198. 2009.

Chrétien F, et al. Pathogenesis of cerebral Cryptococcus neoformans infection after fungemia. Journal of Infection Disease, v.186,p.522-530. 2002.

Coelho, C., Bocca, A., Casadevall, A. The intracellular life of Cryptococcus neoformans. Annual Review of Pathology Mechanisms of Disease, v.9,p.219-238. 2013.

Coelho, C. et al. Macrophage mitochondrial and stress response to ingestion of Cryptococcus neoformans. Journal of Immunology, v.194,n.5,p.2345-2357. 2015.

Confortin, F.G. Produção de biomassa fúngica da linhagem PS-2001 de Pleurotus sajor-caju (Fr.) Singer em cultura submersa. Mestrado (Mestre em Biotecnologia). 95 f. Universidade de Caxias do Sul - RS. 2006.

Coung, D.V. et al. Mitocondrial calcium uniporter inhibition attenuates mouse boné marrow-derived mast cell degranulation induced by beta-1,3-glucan. Korean Journal of Physiological Pharmacological, v.20,n.2,p.213-220. 2016.

Cox, G.M. et al. Urease as a virulence factor in experimental cryptococcosis. Infection and Immunity. v.68,n.2,p.443-8. 2000.

Cui, F.J., et al. Optimization of the medium composition for production of mycelia biomass and exo-polymer by Grifola frondosa GF9801 using response surface methodology. Bioresource Technology, v.97,p.1209-1216. 2006. 
Cui, F.J. et al. Structural analysis of anti-tumor heteropolysaccharide GFPS1b from the cultured mycelia of Grifola frondosa GF9801. Bioresource Technology, V.98, p.395401. 2007.

Cummings, B.S., Wills, L.P. e Schnellmann, R.G. Measurement of cell death in mammalian cells. Current Protocols in Pharmacology, v.56,p.1-24. 2013.

Cummings, R. D. e R.P. McEver. C-type lectins. In Essentials of Glycobiology, 2 ed. Cold Spring Harbor Laboratory Press, Cold Spring Harbor, NY, p. 403-414. 2009.

Dalmo, R. A., \& Bogwald, J. $\beta$-glucans as conductors of immune symphonies. Fish \& Shellfish Immunology, v.25,p.384-396. 2008.

Damazo, A.S. Spatial and temporal profiles for anti-inflammatory gene expression in leukocytes during a resolving model of peritonitis. Journal of Immunology, v.176, n.7, p.4410-4418. 2006.

Davis, J.M. et al. Macrophage M1/M2 polarization dynamically adapts to changes in cytokine microenvironments in Cryptococcus neoformans infection. mBio, v.4,n.3,p.110. 2013.

Denning, D.W. Minimizing fungal disease deaths will allow the UNAIDS target of reducing annual AIDS deaths below 500.000 by 2020 to be realized. Philosophical Transactions B, v.371, p.1-10. 2016.

Denning, D.W.H. e William, W. Therapy for fungal diseases: opportunities and priorities. Trends in Microbiology, v.18,n.5,p.195-204. 2010.

Desalermos, A.; Kourkoumpetis, T. K.; Mylonakis, E. Update on the epidemiology and management of cryptococcal meningitis. Expert Opinion Pharmacotherapy, v.13,p.783-9. 2012.

Dhama, K. et al. Effect of immunomodulation and immunomodulatory agents on health with some bioactive principles, modes of action and potent biomedical applications. International Journal of Pharmacology, v.11,n.4,p.253-290. 2015.

Ding, C. Cryptococcus neoformans copper detoxification machinery is critical for fungal virulence. Cell Host \& Microbe, v.13,n.3,p.265-276. 2013.

Djordjevic, J.T. Roleof phospholipases in fungal fitness, pathogenicity and drug development - lessons from Cryptococcus neoformans. Frontiers in Microbiology, v.1p.125. 2010.

Doni, A. et al. Cell-specific regulation of PTX3 by glucocorticoid hormones in hematopoietic and nonhematopoietic cells. Journal of Biological Chemistry, v.283, n. 44, pp.29983-29992. 2008.

Donot, F., Fontana, A., Baccou, J.C. e Schorr-Galindo, S. Microbial exopolysaccharides: main examples of synthesis, excretion, genetics and extraction. Carbohydrate Polymers, v.87,p.951-962, 2012. 
Dromer, F. et al. Cryptococcus neoformans: latency and disease, in Cryptococcus from human pathogen to model yeast. J Heitman, et al. Editors. 2011. ASM Press: Washingtion, DC.

Drummond, A. e Brown, G. The role of dectin-1 in the host defence against fungal infections. Current Opinion in Microbiology, v.12,p.392-399. 2011.

Drummond, R.A e Lionakis, M.S. Mechanistic Insights into the Role of C-Type Lectin Receptor/CARD9 Signaling in Human Antifungal Immunity. Frontiers in Cellular and Infection Microbiology, v.6,n.39,p.1-11. 2016.

Du P. et al. Genetic diversity of wild Auricularia auricula-judae revealed by ISSR analysis. Biochemical Systematics and Ecology, v.48,p.199-205. 2013.

DuBois, M. et al. Colorimetric method for determination of sugars and related substances. Analytical Chemistry, v.28,n.3,p.350-356. 1956.

Dubey, L.K. et al. Induction of innate immunity by Aspergillus fumigatus cell wall polysaccharides is enhanced by the composite presentation of chitin and beta-glucan. Immunobiology, v.219,n.3,p.179-188. 2014.

Eisenman, H.C. Cryptococcus neoformans laccase catalyses melanin synthesis from both D-and L-DOPA. Microbiology. v.153,p.3954-62. 2007.

Enshasy, H.A.E. e Hatti-Kaul, R. Mushroom immunomodulators: unique molecules with unlimited applications. Trends in Biotechnology, v.31,n.12,p.668-77. 2013.

Erickson, T. et al. Multiple virulence factors of Cryptococcus neoformans are dependent on VPH1. Molecular Microbiology, v.42,p.4,p.1121-31. 2001.

Esteban. E. et al. Immunomodulation in sepsis: the role of endotoxin removal by polymyxin B-immobolization cartridge. Mediators of Inflamation, p.1-12. 2013.

Evans, E.E. The antigenic composition of Cryptococcus neoformans. I.A. Serologic classification by means of capsular and agglutination reactions. Journal of Immunology, v.64,n.5,p.423-430. 1950.

Fan W. et al. Cryptococcus neoformans gene expression during murine macrophage infection. Eukaryotic Cell, v.4,n.8,p.1420-33. 2005.

Fang, Q.H. e Zhong, J.J. Submerged fermentation of higher fun- gus Ganoderma lucidum for production of valuable bioactive metabolites - ganoderic acid and polysaccharide. Biochemical Engineering Journal, v.10,p.61-65. 2002.

Feeney, M.J. et al. Mushroom and health summit proceedings. The Journal of Nutrion, v.144,n.7,p.1128S-1136S. 2014.

Feldmesser, M. et al. Cryptococcus neoformans is a facultative intracelular pathogen in murine pulmonary infection. Infection and Immunity, v.68,n.7,p.4225-37. 2000. 
Feldmesser, M. Dynamic changes in the morphology of Cryptococcus neoformans during murine pulmonary infection. Microbiology, v.147,p.2355-2365. 2001.

Ferreira, S.S. et al., Structure-function relationships of immunostimulatory polysaccharides: A review. Carbohydrate Polymers, v.132,p.378-396. 2015.

Ferrante, C.J. e Leibovich, S.J. Regulation of macrophage polarization and wound healing. Advances in Wound Care, vol. 1, no. 1, pp. 10-16, 2012.

Ferreira, S.S. Structure-function relationships of immunostimulatory polysaccharides: a review. Carbohydrate Polymers, v.132,p.378-96. 2015.

Filler, S. G. et al. Candida albicans stimulates cytokine production and leukocyte adhesion molecule expression by endothelial cells. Infection and Immunity, v. 64, n.7, p. 2609-2617, 1996.

Filipuzzi, I. et al. High-Resolution Genetics Identifies the Lipid Transfer Protein Sec14p as Target for Antifungal Ergolines. PLoS Genetics, v.12,n.11,p.e10006374

Fooksman, D.R. et al. Functional anatomy of $\mathrm{T}$ cell activation and synapse formation. Annual Review of Immunology, v.28,p.79-105. 2010.

Fraga, I. et al. Influence of culture medium growth variables on Ganoderma lucidum exopolysaccharides structural features. Carbohydrate Polymers, v.11,p.936-946. 2014.

Freimund, S. et al. A new non-degrading isolation process for 1,3- $\beta$-D-glucan of high purity from baker's yeast Saccharomyces cerevisiae. Carbohydrate Polymers, 54, 159$171,2003$.

Fuentes, A.L., Millis, L. e Sigola, L.B. Laminarin, a soluble beta-glucan, inhibits macrophage phagocytosis of zymosan but has no effect on lipopolysaccharide mediated augmentation of phagocytosis. International Immunopharmacology, v.11,1939-1945. 2011.

Galluzzi, L., et al. Guidelines for the use and interpretation of assays for monitoring cell death in higher eukaryotes. Cell Death and Differentiation, v16,p.1093-1107. 2009.

Gantner, B.N. et al. Collaborative induction of inflammatory responses by dectin-1 and Toll-like receptor 2. The Journal of Experimental Medicine, v.197,p.1107-1117. 2003.

Garcia-Solache, M. e Casadevall, A. Global warming will bring new fungal diseases for mammals. MBio, v.1,n.1,p.1-3. 2010.

Garianda, C. et al., Non-redundant role of the long pentraxin PTX3 in anti-fungal innate immune response. Nature, v.420, n.6912, pp.182-186, 2002.

Giaimis J., et al. Both mannose and beta-glucan receptors are involved in phagocytosis of unopsonized, heat-killed Saccharomyces cerevisiae by murine macrophages. Journal of Leukocyte Biology, v.54,p.564-71. 1993. 
Giavasis, I. Polysaccharides. Natural Fibers in Food and Nutrition. In Polysaccharides from medicinal mushrooms for potential use as nutraceuticals. 1 ed. CRC Press. Florida. 2014.

Gil, M.L. e Gozalbo, M. Role of Toll-like receptors in systemic Candida albicans infections. Frontiers in Biosicence, v.14,p.1970-8. 2009.

Gnauck, A., Lentle, R.G. e Kruger, M.C. The Limulus Amebocyte lysate assay may be unsuitable for detecting endotoxin in blood of healthy female subjects. Journal of Immunology Methods, v.416,p.146e56. 2015.

Goldman, D.L. et al. Serologic evidence for Cryptococcus neoformans infection in eraly childhood. Pediatrics, v.107,n.5,p.E66. 2001.

Gonçalves, J.M. Espécies comestíveis de cogumelos: perfil mineral, bioacumulação de metais e procedimentos de preparo de material de referência certificado. Tese (Doutor em Vigilância Sanitária) 110 f. Fundação Oswaldo Cruz. 2012.

Goodridge, H.S. et al. Activation of the innate immune receptor Dectin-1 upon formation of a 'phagocytic synapse'. Nature, v.472,p.471-475. 2011.

Gorin P.A. e Spencer J.F. Structural chemistry of fungal polysaccharides. Advances in Carbohydrate Chemistry and Biochemistry, v.23,p.367-417. 1968.

Grallert, H. et al. EnsoLISA ${ }^{\circledR}$ : a novel and realible method for endotoxin detection. Nature Methods, v.8,p.1-5. 2011.

Green, L.C., Tannenbaum, S.R., Goldman, P. Nitrate synthesis in the germfree and conventional rat. Science, v. 212, p. 56-58, 1981.

Griffiths, E. J.; Kretschmer, M.; Kronstad, J. W. Aimless mutants ofCryptococcus neoformans: Failure to disseminate. Fungal Biology Reviews, 2012; 26: 1-12.

Gringhuis, S.I. Dectin-1 directs T helper cell differentiation by controlling noncanonical NFkB activation through Raf-1 and Syk. Nature Immunology, v.10,n.2,p.203- 213. 2009.

Guillot, L. et al. Enhanced innate immune responsiveness to pulmonary Cryptococcus neoformans infection is associated with resistance to progressive infection. Infection and Immunity, v.76,n.10,p.4745-56. 2008.

Guo, C. et al. Acapsular Cryptococcus neoformans activates the NLRP3 inflammasome. Microbes and Infection, v.16,n.10,p.845-54. 2014.

Hawksworth, D.L. Mushroom: the extent of the unexplored potential. International Journal of Medicinal Mushroom, v.3,p.333-337. 2001.

He, W. et al. Phagocytic activity and monocyte chemotatic protein expression by pulmonar macrophages in persistente pulmonar cryptococcosis. Infection and Immunity, v.71,n.2,p.930-6. 2003. 
Hernandez, Y. et al. Distinct roles for IL-4 and IL-10 in regulating T2 immunity during allergic bronchopulmonary mycosis. Journal of Immunology, v.174,p.1027-1036. 2005.

Hermanns, J. el al. Alternatives to animal use for LAL-assay. ALTEX proceedings, p.8184. 2012.

Herre, J., Gordon, s. e Brown, G.D. Dectin-1 and its role in the recognition of beta-glucans by macrophages. Molecular Immunology, v.40,n.12,p.869-76. 2004.

Herrera, O.M. Produção, economicidade e parâmetros energéticos do cogumelo Agaricus blazei: um enfoque de cadeia produtiva. 2001. 200f. Tese de Doutorado (Doutora em Agronomia), Universidade Estadual Paulista "Júlio de Mesquita Filho" UNESP - SP. 2001.

Herring A.C. et al. Induction of interleukin-12 and gamma interferon requires tumor necrosis factor alpha for protectiveT1-cell-mediated immunity to pulmonary Cryptococcus neoformans infection. Infection and Immunity, v.70,n.6,p.2959-2964. 2002.

Hope, W., Natarajan, P. e Goodwin, L. Invasive fungal infections. Clinical Medicine, v.13,n.5,p.507-10. 2013.

Hsu, H.Y. Extract of Reish polysaccharides induces cytokine expression via TLR4modulated protein kinase signaling pathways. Journal of Immunology, v.173,p.59895999. 2004.

Hsu, P.Y. Extract of Sporoderm-Broken Germinating Spores of Ganoderma lucidum Activates Human Polymorphonuclear Neutrophils via the P38 Mitogen-activated Protein Kinase Pathway. Chang Gung Medical Journal, v.35,n.2,p.140-7. 2012.

Huang, H. et al. Robust stimulation of humoral and cellular immune responses following vaccination with antigen-loaded $\beta$-glucan particles. MBio, v.1: e00164-e001610. 2010.

Huang, H. et al. Regulatory dendritic cell expression of MHCII and IL-10 are jointly requisite for induction of tolerance in a murine model of OVA-asthma. European Journal of Allergy and Clinical Immunology, v.68,p.1126-1135. 2013a.

Huang, H. et al. Characterization and optimization of the glucan particle-based vaccine platform. Clinical and Vaccine Immunology, v.20,n.10,p.1585-1591. 2013 b.

Huang, J.H. et al. CR3 and dectin-1 collaborate in macrophage cytokine response through association on lipid rafts and activation of Syk-JNK-AP-1 pathway. PLoS Pathogens, v.11,n.7,1-26. 2015.

Huang, T.T. et al. The Anti-Tumorigenic Mushroom Agaricus blazei Murill Enhances IL-1b Production and Activates the NLRP3 Inflammasome in Human Macrophages. PLoS ONE, v.7,n.7, e41383. 2012. 
Hui-Xin, Z. et al. effect of polysaccharides from Auricularia auricular on immunologic function in mice. Progress in Venerinary Medicine, p.01-07. 2009.

Hull, C.M. e Heitman, J. Genetics of Cryptococcus neoformans. Annuual Review of Genetics, v.36,p.557-615. 2002.

Jackson A. et al New insights in the prevention, diagnosis, and treatment of cryptococcal meningitis. Current. HIV/AIDS Rep., v.9,n.3,p.267-277. 2012.

Jiang, Z.Y. e Lin, C. Study of Ganoderma lucidum polysaccharide on effects of cellular immune function in mice. Journal of Microbiolology, v.23,p.51-54. 2003.

Johnson, E. et al. Effect of an extract based on the medicinal mushroom Agaricus blazei murill on release of cytokines, chemokines and leukocyte growth factors in human blood ex vivo and in vivo. Clinical immunology. Scandinavian Journal of Immunology, v.69,n.3,p.242-50. 2009.

Johnston, S.A. e May, R.C. The human fungal pathogen Cryptococcus neoformans escapes macrophages by a phagosome emptying mechanism that is inhibited by Arp $2 / 3$ complex-mediated actin polymerization. PLoS Pathogens, v.6,n.8, 2010.

Jung, W.H. et al. Iron regulation of the major virulence factors in the AIDS-associated pathogen Cryptococcus neoformans. PLoS Biology, v.4, e410.2006.

Jung, W.H. et al. Role of ferroxidases in iron uptake and virulence of Cryptococcus neoformans. Eukaryotic Cell, v.8,p.1511-1520. 2009.

Kadnikova, I.A. et al. Chemical composition and nutritional value of the mushroom Auricularia auricular-judae. Journal of Food and Nutrition Research, v.3,n.8,p.478482. 2015.

Kaiko, G.E. et al. Immunological decision-making: how does the immune system decide to mount a helper T-cell response? Imunology, v.123,n.3,p.326-38. 2008.

Kataoka, K. et al. Activation of macrophages by linear $(1 \rightarrow 3)-\beta$-D-Glucans. The Journal of Biological Chemistry, v.277,n.39,p.36825-36831. 2002.

Khil'chenko, S.R. et al. Immunostimulatory activity of fucoidan from the brown alga Fucus evanescens: Role of sulfates and acetates. Journal of Carbohydrate Chemistry, v.30,n.903,p.291-305. 2011.

Kiggundu. R. et al. Unmasking cryptococcal meningitis immune reconstitution inflammatory syndrome in pregnancy induced by HIV antiretroviral therapy with postpartum paradoxical exacerbation. Mendical Mycology Case Reports, v.5,p.16-19. 2014.

Kim, D.H. et al Production of hypoglycemic, extracellular polysaccharide from the submerged culture of the mushroom, Phellinus linteus. Biotechnology Letters, v.23,p.513-517. 2001. 
Kim, H.M. et al. Stimulation of humoral and cell mediated immunity by polysaccharide from mushroom Phellinus linteus. International Journal of Immunopharmacology, v.18,n.5,p.295-303. 1996.

Kim, H.S. Curdlan activates dendritic cells through dectin-1 and toll-like receptor 4 signaling. International Immunopharmacology, v.39,p.71-78. 2016.

Kim, K. et al. Cyclo (Phe-Pro) Produced by the human pathogen Vibrio vulnificus inhibits host innate immune responses through the NF- $\kappa \mathrm{B}$ pathway. Infection and Immunity, v.83,p.n.3,p.1150-61. 2015.

Kirk, P.M., Cannon PF, David JC, Stalpers. Ainsworth \& Brisby's dictionary of the fungi, 10th ed. CAB International,Wallingford. 2008.

Knirel, Y.A. e Valvano, M.A. Bacterial Lipopolysaccharides. Struture, Chemical Synthesis, Biogenesis and Interaction with Host Cells. 1 ed., Springer. New York. 453 pagínas. 2011.

Koch, F. et al. High level IL-12 production by murine dendritic cells: upregulation via MHC class II and CD40 molecules and downregulation by IL-4 and IL-10. Journal of Experimental Medicine, v.84,p.741-6. 1996.

Kozel. T.R. et al. Role of the capsule in phagocytosis of Cryptococcus neoformans. Reviews of Infectious Diseases, v.10,n.2,p.S436-9. 1988.

Kozel T.R. et al. Antigenic and biological characteristics of mutant strains of Cryptococcus neoformans lacking capsular $\mathrm{O}$ acetylation or xylosyl side chains. Infection and Immunity, v.71,n.5,p.2868-75. 2003.

Krainer E. et al. Direct observation of cell wall glucans in whole cells of Saccharomices cerevisiae by magic-angle spnning 13C-NMR. Biopolymers. v.34,n.12,p.1627-35. 1994.

Kronin, V. et al. Regulation of T cell cytokine production by dendritic cells. Immunology and Cell Biology, v.78.p.214-223. 2000.

Kobayashi, H. et al. Development of an in vivo immunobiotic evaluation system against rotavirus infection in bovine intestinal epitheliocytes. Beneficial Microbes, v.2,p.1-14. 2017.

Kozubowski L, Lee SC, Heitman J. Signalling Pathways in the Pathogenesis of Cryptococcus. Cellular Microbiology, v.11,p.370-80. 2009.

Kunes, P. et al. Pentraxin 3 (PTX3): na endogenous modulator of the inflammatory response. Mediators of Inflammation, v.2012,n.920517,p.1-10. 2012.

Lai, C.Y. et al. Immunomodulatory and adjuvant activities of a polysaccharide extract of Ganoderma lucidum in vivo and in vitro. Vaccine, 28: 4945-4954. 2010. 
Lee, D.H. e Kim, H.W. Innate immunity induced by fungal B-glucan via dectin-1 signaling pathway. International Journal of Medicinal Mushrooms, v.16,n.1,p.1-16. 2014.

Lehninger, A.L. et al. Lehninger Princípios de Bioquímica. 3. ed. São Paulo: Sarvier, 2002.

Lemos, F.M.R. Elaboração e caracterização de produto análogo a hambúrguer de cogumelo Agaricus brasiliensis. Dissertação (Mestre em Tecnologia de Alimentos), 147f. Universidade Federal do Paraná-UFPR. 2009.

Leonowicz, A. et al. Higher fungi as a potential feed and food source from lignocellulosic wastes. Environmental Biotechnology, v.42,p.229-255. 1991.

Levitz, S.M. et al. Cryptococus neformans resides in an acidic phagolysosome of human macrophages. Infection and Immunity, v.67,n.2,p.885-90. 1999.

Levitz, S. M. Innate recognition of fungal cell walls. PLoS Pathogens, v. 6,n.4, e1000758 2010.

Li, M.C. et al. Effect of Ganoderma polysaccharides on IL-1 $\alpha$ and tumor necrosis factor $\alpha$ mRNA expression in murine peritoneal macrophages. Chinese Journal of Pharmacological Toxicology. v.14:27-229. 2000

Li, L., Zhong, C.H. e Bian, Y.B. The molecular diversity analysis of Auricularia auricular-judae in China by nuclear ribosomal DNA intergenic spacer. Electronic Journal of Biotechnology, v.17,p.27-33. 2014.

Li, Z. et al., Preparation of a novel glucuronomannan from Auricularia auricula and its immunological activity. Natural Products Communication, v.7,n.11,p.1507-10. 2012.

Lim, T.S. et al. Mechanical interactions between dendritic cells and T cells correlate with T cell responsiveness. The Journal of Immunology, v.187,n.1,p.258-65. 2011.

Lim, T.S. CD80 and CD86 Differentially Regulate Mechanical Interactions of T-Cells with Antigen-Presenting Dendritic Cells and B-Cells. PloS One, v.12,n.9,p.1-8. 2012.

Lin, X. e Heitman, J. The biology of the Cryptococcus neoformans species complex. Annu. Rev. Microbiol, v.60,p.69-105. 2006.

Lin, Z.B. Modern research on Ganoderma. 2 ed. Editora Beijing Medical University Press, Beijing, 2001.

Lindequist, U., Niedermeyer, T.H. e Jülich, W.D. The Pharmacological Potential of Mushrooms. Evidence- Based Complementary and Alternative Medicine, v.2,n.3,p.285-99. 2005.

Lionakis, M.S. e Netea, M.G. Candida and host determinants of susceptibility to invasive candidiasis. PLoS Pathogens, v.9,n.1,p.1-5. 2013. 
Liu M. et al. Induction of immunomodulating cytokines by a new polysaccharide-peptide complex from culture mycelia of Lentinus edodes. Immunopharmacology, v.40,n.3,p.187-198. 1998.

Liu, X.Y. et al. A new isolation method of b-D-glucans from spent yeast Saccharomyces cerevisiae. Food Hydrocolloids, v.22,p.239-247. 2008.

Lo, H.C. e Wasser, S.P. Medicinal mushroom for glycemic control in diabetes: histry, current statuts, future, perspectives, and unsolved problems. International Journal of Medicinal Mushroom, v.13,n.5,p.401-426. 2011.

Lobato-Pascual, A. et al. Mincle, the receptor for mycobacterial cord factor, forms a functional receptor complex with MCL and FceRI-g. European Journal of Immunology, v.43,p.3167-3174. 2013.

Loverock, B. et al. A recombinant factor C procedure for the detection of Gramnegative bacterial endotoxin. Pharmacopeial Forum, v.36,p.321-329. 2010.

Low, C.W. e Rotstein, C. Emerging fungal infections in immunocompromised patients. F1000 Reports Medicine, v.3,n.14,p.01-08. 2011.

Lucas, E.H. Tumor inhibitors in Boletus edulis and other holobasidiomycetes. Antibiotics Chemotherapy, v.7,n.1-4, 1957.

Lucisano, Y.M. e Mantovani, B. Lysosomal enzyme release from polymorphonuclear leukocytes induced by immune complexes of IgM and of IgG. Journal of Immunology, v.132,n.4,p.2015-20. 1984.

Lugt et al. Transcriptional programming of dendritic cells for enhanced MHC class II antigen presentation. Nature Immunology, v.15,n.02,p.161-9. 2014.

Lull, C., Wichers, H.J., Savelkoul H.F.J. Antiinflamatory and immunomodulating properties of fungal metabolites. Mediators of Inflammation, v.2005,n.2,p.63-80. 2005.

Lutz, M.B. et al. An advanced culture method for generating large quantities of highly pure dendritic cells from mouse bone marrow. Journal of Immunological Methods, v.223,v.1p.77-169. 1999.

Lutz, M.B. et al. Culture of bone marrow cells in GM-CSF plus high doses of lipopolysaccharide generates exclusively immature dendritic cells which induce alloantigen-specific CD4 T cell anergy in vitro. European Journal of Immunology, v.30,n.4,p.1048-1100. 2000.

Ma, Z. et al. Evaluation of water soluble $\beta$ - D-glucan from Auricularia auricular-judae as potential anti-tumor agent. Carbohydrate Polymers, v.80,n.3,p.977-983. 2010.

McQuiston, T.J. e Williamson, P.R. Paradoxical roles of alveolar macrophages in the host response to Cryptococcus neoformans. Journal Infection of Chemotherapy, v.18,p.19. 2012. 
Madigan, M. et al. Microbiologia de Brock. 12 edição, editora Artmed. 1160 páginas. 2010 .

Manzi, P., \& Pizzoferrato, L. Beta-glucans in edible mushrooms. Food Chemistry,v.68,p.315-318. 2000.

Mao, K. et al. Nitric oxide suppresses NLRP3 inflammasome activation and protects against LPS-induced septic shock. Cell Research, v.23,n.2,p.201-212. 2013.

Martins, R.P. et al. Polysaccharide-rich fraction of Agaricus brasiliensis enhances the candidacidal activity of murine macrophages. Memórias do Instituto Oswald Cruz, v.103,n.3, p.244-250. 2008.a.

Martins, P.R. O papel de receptores de imunidade inata BGR, MR, TLR2 e TLR4 no reconhecimento da Candida albicans por monócitos humanos estimulados com polissacarídeos extraídos do cogumelos Agaricus brazsiliensis. Tese (Doutora em Patologia). 79 f. Universidade Estadual Paulista Julio de Mesquita Filho. Botucatu UNESP. Botucatu - SP. 2008.b.

Maziero, R. et al. Screening of basidiomycetes for the production of exolpolysaccharide and biomass in submerged culture. Revista de Microbiologia, v.30,p.77-84. 1999.

McCann, F. et al. Macrophage internalization of fungal $\beta$-glucans is not necessary for initiation of related inflammatory responses. Infection and Immunity, v.73,n.10,p.634049. 2005.

Megias, J. et al. TLR2, TLR4 and Dectin-1 signalling in hematopoietic stem and progenitor cells determines the antifungal phenotype of the macrophages they produce. Microbes and Infection, v.16. p.S1286-4579. 2016.

Medzhitov, R. Approaching the asymptote: 20 years later. Immunity, v.30,p.766-775. 2009.

Meyer, W. et al. Consensus multi-locus sequence typing scheme for Cryptococcus neoformans and Cryptocuccus gattii. Medical Mycology, v.47,n.6,p.561-570. 2009.

Mezger, M. et al. Proinflamatory response of immature huan dendritic cells is mediated by dectin-1 after exposure to Aspergillus fumigatus germ tubes. The Journal if Infectious Diseases, v.197,p.924-31. 2008.

Mifsud, E.J., Tan, A.C. e Jackson, D.C. TLR agonists as modulators of the innate immune response and their potential as agents against infectious disease. Frontiers in Immunology, v.5,n.79,p.1-10. 2014.

Minato, K.I. et al., Pleurotus citrinopileatus polysaccharide induces activation of human dendritic cells through multiple pathway. International Immunopharmacology, v.40,p.156-163. 2016. 
Miyake, Y. et al. C-Type Lectin Receptor MCL Facilitates Mincle Expression and Signaling through Complex Formation. The Journal of Immunology, v.194,n.11,p.5366-74. 2015.

Moncada, S. e Higgs, A. The L-arginine-nitric oxide pathway. The New England Journal of Medicine, v.329,n.27,p.2002-12. 1993.

Monteiro, L.P. Determinação da atividade citotóxica do extrato vegetal de Croton urucurana Baill em linhagens de células tumorais. Mestrado (Mestre em Magister Scientiae). 103 f. Universidade Federal de Viçosa - UFV. 2015.

Morris, D.L.; Singer, K. e Lumeng, C.N. Adipose tissue macrophages: phenotypic plasticity and diversity in lean and obese states. Current Opinion in Clinical Nutrition and Metabolic Care, v. 14, n. 4, pp. 341-346. 2011.

Morgan, W. T. J. Studies in immuno-chemistry. I. The preparation and properties of a specific polysaccharide from $B$. dysenteriae (Shiga). Biochemical Journal, v.30,p. 909925. 1936.

Mueller, G.M. e Schmit, J.P. Fungal biodiversity: what do we know? What can we predict? Biodiversity and Conservation, v.16,p.01-05. 2007.

Muller, U. et al. IL-13 induces disease-promoting type 2 cytokines, alternatively activated macrophages and allergic inflammation during pulmonary infection of mice with Cryptococcus neoformans. Journal of Immunology, v.179,n.8,p.536-77. 2007.

Municio, C. et al. The response of human macrophages to $\beta$-glucans depends on the inflammatory milieu. PLoS ONE, v.8,p.e62016. 2013.

Naglik, J.R. Candida Immunity. New Journal of Science, v.2014,n.390241,p.1-27. 2014.

Nair, P.K. et al. Mechanism of macrophage activation by $(1,4)$-alpha-D-glucan isolated from Tinospora cordifolia. International Immunopharmacology, v.6,p.1815-24. 2006.

Naslund, P.K., Miller, W.C. e Granger, D.L. Cryptococcus neoformans fails to induce nitric oxide synthase in primed murine macrophage-like cells. Infection and Immunity, v.63,p.1298-1304. 1995.

Nyman, A.A.T. et al. Structural characterization of a branched (1-6)- $\alpha$-mannan and Bglucans isolated from the fruiting bodies of Cantharellus cibarus. Carbohydrate Polymers, v.146,p.197-207. 2016.

Odds, F.C. Antifungal agents: their diversity and increasing sophistication. Mycologist, v.17,n.02,p.51-5. 2003.

Offiah, C.E. e Naseer, A. Spectrum of imaging appearances of intracranial cryptococcal infection in HIV/AIDS patients in the anti-retroviral therapy era. Clinical Radiology, v.71, n.1,p.9-17. 2016. 
Ohta, Y. et al. In vivo anti-influenza virus activity of an immunomodulatory acidic polysaccharide isolated from Cordyceps militaris grown on germinated soybeans. Journal of Agricultural and Food Chemistry, v.55,p.10194-10199. 2007.

Ormerod, M.G. et al. Apoptosis in interleukin-3-dependent haemopoietic cells. Quantification by two flow cytometric methods. Journal of Immunology Methods, v.153,p.57-65. 1992.

Osinska-Jaroszuk, M. et al. Extracellular polysaccharides from Ascomycota and Basidiomycota: production conditions, biochemical characteristics, and biological properties. World Journal of microbiology and Biotechnology, v.31,p.1823-1844. 2015.

Osterholzer, J.J. et al. Cryptococcal urease promotes the accumulation of immature dendritic cells and a non-protective T2 immune response within the lung. The American Journal of Pathology, v.174,p.932-943. 2009a.

Osterholzer, J.J et al. Role of dendritic cells and alveolar macrophages in regulating eraly host denfense against pulmonar infection with Cryptococcus neoformans. Infection and Immunity, v.77,n.9,p.3750-58. 2009b.

Ozment, T.R. et al. Soluble glucan is internalized and trafficked to the golgi apparatus in macrophages via a clathrin-mediated, lipid raft-regulated mechanism. The Journal of Pharmacology and Experimental Therapeutics, v.342,n.3,p.808-15. 2012.

O'Meara, T.R. e Alspaugh, J.A. The Cryptococcus neoformans capsule: a sword and a shield. Clinical Microbiology Reviews, v.25,p.387-408. 2012.

Paramythiotou, E. et al. Invasive fungal infections in the ICU: how to approach, how to treat. Molecules, v.9n.1,p.1085-1119. 2014.

Park, B.J. et al. Estimation of the current global burden of cryptpcpccal meningitis among persons living with HIV/AIDS. AIDS, v.23,n.4,p.525-530. 2009.

Parveen, Y. Lipids and the immune response: from molecular mechanisms to clinical applications. Current Opinion in Clinical Nutrition \& Metabolic Care, v.6,n.2,p.133150. 2003.

Patel, M. et al. Transplacental transmission of Cryptococcus neoformans to an HIVexposed premature neonate. Journal of Perinatology, v.32,p.235-237. 2012.

Peng, L. et al. Effects of culture conditions on monosaccharide composition of Ganoderma lucidum exopolysaccharide and on activities of related enzymes. Carbohydrate Polymers, v.133,p.104-109. 2015.

Perfect, J.R., et al. Clinical practice guidelines for the management of cryptococcal disease: 2010 update by the infectious diseases society of America. Clinical Infection Disease, v.50,n.3,p.291-322. 2010. 
Piotrowski, J., Jedrzewski, T. e Kozak, W. Immunomodulatory and antitumor properties of polysaccharide peptide (PSP). Progress of Hygiene and Experimental Medicine, v.69,p.91-7. 2015.

Polentarutti, N. et al. Inducible expression. Of the long pentraxin PTX3 in the central nervous system. Journal of Neuroimmunology, v.106,n.1-2,p.87-94. 2000.

Powderly, W.G. Cryptococcal Meningitis in HIV Infected Patients. Current Infection Disease Reports, v.2,p.352- 7; 2000.

Prado, $\mathrm{M}$ et al. Mortality due to systemic mycoses as a primary cause of death or in association with AIDS in Brazil: a review from 1996 to 2006. Memórias do Instistuto Oswaldo Cruz, v.104,n.3,p.513-521. 2009

Pyrgos, V. et al. Epidemiology of cryptococcal meningitis in the US: 1997-2009. PLoS ONE, v.8,n.2. 2013.

Raele, R.A. Avaliação da citotoxicidade de quantum dots, in vitro, em células RAW 264.7. Mestrado (Mestre em Biologia Aplicada à Saúde). 77 f. Universidade Federal de Pernambuco - UFP. 2013.

Rai, M. et al. Antioxidant and nitric oxide synthase activation properties of Auricularia auricula. International Journal of Biomedical and Pharmaceutical Sciences, v.1,n.2,p.160-63. 2004.

Ramana, K.V. et al., Invasive fungal infections: a comprehensive review. American Jornaul of Infectious Diseases and Microbiology, v.1,n.4,p.64-69. 2013.

Ramberg, J.E., Nelson, E.D., Sinnott, R.A. Immunomodulatory dietary polysaccharides: a systematic review of the literatute. Nutritional Journal, v.9,n.54,p.01-22. 2010.

Ramesh, H.P., Yamaki, K., e Tsushida, T. Effect of fenugreek (Trigonella foenumgraecum L.) galactomannan fractions on phagocytosis in rat macrophages and on proliferation and IgM secretion in HB4C5 cells. Carbohydrate Polymers, v.50,p.79-83. 2002.

Rappleye, C.A. e Goldman, W.E. Fungal stealth technology. Trends in Immunology, v.29,p.18-24. 2008.

Rathore, S.S. Recent advancements in combinational antifungal therapy and immunotherapy. Recent Trends in Antifungal Agents and Antifungal Therapy. 1 ed. Springer. India. 2016.

Reich, J. Masking of endotoxin in surfactant samples: effects on Limulus-based detection systems. Biologicals, v.44,p.417-422. 2016.

Retini C. et al. Capsular polysaccharide of Cryptococcus neoformans induces proinflammatory cytokine release by human neutrophils. Infection and Immunity, v.64,n.8,p.2897-2903. 1996. 
Revskaya, E. et al. Compton scattering by internal shields based on melanin-containing mushrooms provides protection of gastrointestinal tract from ionizing radiation. Cancer Biotherapy \& Radiopharmaceuticals, v.27,p.570-6. 2012.

Riss, T.L. et al. Cell viability assays. Assay Guidance Manual. Ed. Eli Lilly. 2016. Disponível em: https://www.ncbi.nlm.nih.gov/books/NBK144065/. Acessado em: 12 Nov 2016.

Rizzetto, L. Fungal chitin induces trained immunity in human monocytes during crosstalk of the host with Sacchorimyces cerevisiae. The Journal of Biological Chemistry, v.291,n.15,p.7691-72. 2016.

Robert, V.A. e Casadevall, A. Vertebrate endothermy restricts most fungi as potential pathogens. Journal Infectious Disease, v.200,n.10,p.1623-6. 2009.

Rodríguez, M.R. et al. Poparization of the innaye imune response by prostaglandina E2: a puzzle of receptors and signals. The American Society for Pharmacological and Experimental Therapeutic, v.86,p.197-197. 2014.

Rogers, N. C. et al. Syk-dependent cytokine induction by dectin-1 reveals a novel pattern recognition pathway for C-type lectins. Immunity, v.22,p.507-517. 2005.

Rohatgi, S \& Pirofski, L.A. Host immunity to Crytococcus neoformans. Future Microbiology, v.10,n.4,p.565-581. 2015.

Romani, L. Immunity to fungal infections. Nature Reviews Immunology, v.11,p.275288. 2011.

Rosado, F. R. et al. Biomass and exopolysaccharide production in submerged cultures of Pleurotus ostreatoroseus Sing. and Pleurotus ostreatus "florida" (Jack.: Fr.) Kummer. Journal of Basic Microbiology, v.43,p.230-237. 2003.

Rosas, M. et al. The induction of inflammation by dectin-1 in vivo is dependent on myeloid cell programming and the progression of phagocytosis. Journal of Immunology, 181:3549-3557. 2008.

Roszer, T. Understandng the mysterious M2 macrophage through activation markers and effector mechanisms. Mediators of Inflammation, v.2015,n.ID816460,p.1-16. 2015.

Rowan, N.J. et al. Immunomodulatory activities of mushroom glucans and polysaccharide-protein complexes in animals and humans. International Journal of Medicinal Mushrooms, 5, 95-110, 2003.

Samuelsen, A.B. et al. Immunomodulatory activity of dietary fiber: arabinoxylan and mixed-linked beta-glucan isolated from barley show modest activities in vitro. International Journal of Molecular Sciences, v.12,p.570-587. 2011.

Santos, T.C. Caracterização functional dos genes Velvet Vea e Velc no fungo patogênico humano Cryptococcus neoformans. Dissertação de Mestrado (Mestre em Ciências e Tecnologias em Saúde). 94 f. Universidade de Brasília-DF. 2014. 
Sanzen, I. et al. Nitric oxide-mediated antitumor activity induced by the extract from Grifola frondosa (Maitake mushroom) in a macrophage cell line, RAW264.7. Journal of Experimental \& Clinical Cancer Research: CR. v.20,n.4,p.591-7. 2001.

Schepetkin, I.A. et al. Macrophage immunomodulatory activity of polysaccharides isolated from Juniperus scopolorum. International Immunopharmacology, v.5,p.17831799. 2005.

Schepetkin, I.A. e Quinn, M.T. Botanical polysaccharides: Macrophage immunomodulation and therapeutic potential. International Immunopharmacology, v.6, 317-333, 2006.

Shao B.M. Immune receptors for polysaccharides from Ganoderma lucidum. Biochemical and Biophysical Research Communications, v.323,n.1,p.133-141. 2004.

Sheng Z. New Lead Structures in Antifungal Drug Discovery. Current Medicinal Chemistry, v.18,n.5,p.768. 2011.

Sica, A. e Mantovani, A. Macrophage plasticity and polarization: in vivo veritas. The Journal of Clinical Investigation, v. 122, n. 3, pp. 787-795. 2012.

Siddiqui, A.A.; Shattock, R.J. e Harrison, T.S. Role of capsule and interleukin-6 in longterm imune controlo of Cryptococcus neoformans infection by specifically activated human peripheral bood mononclear cells. Infection and Immunity, 74.,n.9,p.5302-10. 2006.

Silva, L.C; Determinação da composição qu[imica e de compostos bioativos em cogumelos comestíveis. Dissertação de mestrado (Mestre em Engenharia de Alimentos) 74 f. Universidade Estadual do Sudoeste da Bahia - UESB. 2013.

Silva, M. M. Cultivo de cogumelos comestíveis pela técnica Jun-Cao. 2011. $41 \mathrm{f}$. Especialidade (Especialista em Microbiologia). Universidade Federal de Minas Gerais UFMG.

Silva, N. G. Estudo da capacidade antioxidante de cogumelos comestíveis. Dissertação de Mestrado (Mestre em segurança alimentar). 90 f. Universidade de Coimbra, Portugal. 2015.

Siqueira, I.M. Avaliação do tratamento da cromoblastomicose experimental utilizando vacina de DNA (DNA-hsp65). 2010. 109f. Dissertação de Mestrado (Mestre em Patologia Molecular).Universidade de Brasília - UnB.

Smiderle, F.R. Caracterização estrutural de alguns polissacarídeos presentes no basidioma de Pleurotus pulmonarius e aplicações. 2008. $71 \mathrm{f}$. Dissertação (Mestre em Bioquímica) Universidade Federal do Paraná - UFPR.

Smith, J. E. et al. Medicinal mushrooms: a rapidly developing area of biotechnology for cancer therapy and other bioactivities. Biotechnology Letters, v.24,p.1939-1845. 2002. 
Smith, S.H. et al. A simple protocol for using a LDH-based cytotoxicity assay to assess the effects of death and growth inhibition at the same time. PloS ONE, v.6,n.6,e26908. 2011.

Soltani, M. Molecular weight (Mw) and monosaccharide composition (MC): Two major factors affecting the therapeutic action of polysaccharides extracted from Cordyceps sinensis - mini review. Journal of Pure and Applied Microbiology, v.7,n.3,p.16011613. 2013.

Song, J.S. et al. Zymosan and PMA activate the immune responses of mutz3-derived dendritic cells synergistically. Immunology Letters, v.167,p.41-46. 2015.

Soto, E.R. et al. Targeted delivery of glucan particle encapsulated gallium nanoparticles inhibits HIV growth in human macrophages. Journal of Drug Delivery, v.2016,n.8520629,p.1-8. 2016.

Souza, R.S. $\beta$-1,3-glucanases e digestão de leveduras em larvas de Aedes aegypti Linnaeus, 1762 (Diptera: Culicidae): Aspectos fisiológicos e moleculares. Dissertação de mestrado (Mestre em Biologia Celular e Molecular) 123 f. Instituto Oswaldo Cruz FIOCRUZ. RJ. 2014.

Stanikunaite, R. et al. Lanostane-type triterpenes from the mushroom Astraeus pteridis with antituberculosis activity, Journal of Natural Products, v.71,p.2077- 2079. 2008.

Steele, C. et al. Alveolar macrophage-mediated killing of Pneumocystis carinii f. sp. muris involves molecular recognition by the dectin-1 $\beta$-glucan recptor. The Journal of Expimental Medicine, v.198,p.1677-1688. 2003.

Steenbergen JN, et al. Cryptococcus neoformans virulence Is Enhanced after Growth in the Genetically Malleable Host Dictyostelium discoideum. Infection and Immunity, v.71,p.4862-72. 2003.

Steinman, R.M. The control of immunity and tolerance by dendritic cell. Pathologie Biologie, v.51,p.59-60. 2003.

$\mathrm{Su}, \mathrm{C} . \mathrm{H}$. Comparative characterization of physicochemical properties and bioactivities of polysaccharides from selected medicinal mushrooms. Applied Microbiology and Biotechnology, v.100,n.10,p.4385-93. 2016.

Synytsya, A. et al. Glucans from fruit bodies of cultivated mushrooms Pleurotus ostreatus and Pleurotus eryngii: Structure and potential prebiotic activity. Carbohydrate Polymers, v.76,n.4,p.548-556. 2009.

Takeuchi, O. e Akira, S. Pattern recognition receptors and inflammation. Cell, v.140, p.805-820. 2010.

Tang, C. et al. Inhibition od dectin-1 signaling ameriolates colitis by inducing lactobacillus-mediated regulatory T cell expansion in the intestine. Cell Host \& Microbe, v.12,n.8,p.183-97. 2015. 
Tang, Y.J. e Zhong, J.J. Exopolysaccharide biosynthesis and related enzyme activities of the medicinal fungus, Ganoderma lucidum, grown on lactose in a bioreactor. Biotechnology Letters, v.24, p.1023-1026. 2002.

Tang, Q.J. Activation of mouse macrophages by the alkali-extracted polysaccharide from spore of Ganoderma lucidum. Chinese Journal of Cellular and Molecular Immunology, v.20,p.142-144. 2004.

Tavares, A.H. Turning Up the Heat: Inflammasome Activation by Fungal Pathogens. PLoS Pathogens, v.11,n.7,p.1-7. 2015.

Thaiss, C. et al. Integration of Innate Immune Signaling. Trends in Immunology, v.37,n.2,p.84-101. 2016.

Thomaz, L. Proteção ou exarcebação de anticorpos monoclonais gerados contra antígenos de Paracoccidioides brasiliensis na infecção experimental. 2012. 174 f. Tese de Doutorado (Doutora em Ciências). Universidade de São Paulo-SP.

Tong, H. et al. Structural characterization and in vitro antitumor activity of a novel polysaccharide isolated from the fruiting bodies of Pleurotus ostreatus. Bioresource Technology, v.100,n.4,p.1682-1686. 2009.

Tripathi, L. e Meena, K. Genomic identification of potential targets unique to Candida albicans for the discovery of antifungal agents. Current Drug Targets, v.15,n.1,p.13649. 2014.

Tsolmongyn, B. et al. A Toll-like receptor 2 ligand, Pam3CSK4, augments interferoncinduced nitric oxide production via a physical association between MyD88 and interferon-c receptor in vascular endothelial cells. Immunology, v.140,p.352-361. 2013.

Underhill, D.M. e Goodridge, H.S. Information processing during phagocytosis. Nature Reviews Immunology, v.12,p.492-502. 2012.

Universidade de Rai, Índia. Fungi, Course B.S.C. (Micro) Subject: Elementary microbiology. Unit 3.3. Disponível em: http://www.slideshare.net/raiuniversity/bscmicro-i-em-unit-33-fungi. Acessado em: 11 de Setem de 2016.

Valdez, P.A. et al. Prostaglandin-E2 is a potente inhibitor of human interleukin 12 production. The Journal of Experimental Medicine, v.181,p.775-779. 2012.

Van der Meer, J. et al. Trained immunity: a smart way to enhance innate immune defence. Molecular Immunology, v.68,n. 1,p.40-44. 2015.

Vance, D. T. et al. A phagocytosis assay for oxidized low-density lipoprotein versus immunoglobulin G-coated microbeads in human U937 macrophages. Analytical Biochemistry, v.500,p.24-34. 2016.

Varelas, V. et al., An evaluation study of different methods for production of $\beta$-D-glucan from yeast biomass. Drug Testing and Analysis, v.8,46-55. 2015. 
Vecchiarelli, A. Cytokines and costimulatory molecules: positive and negative regulation of the immune response to Cryptococcus neoformans. Archivium Immunologiae et Therapia Experimentalis (Warsz), v.48,n.6,p.465-72. 2000.

Vecchiarelli, A. Fungal capsular polysaccharide and T-cell suppression: the hidden nature of poor immunogenicity. Critical Reviews in Immunology. v.27p.547-557. 2007.

Vetvicka, V. e Vetvickova, J. $\beta$ 1,3-Glucan: Silver bullet or hot air? Open Glycoscience, v.3p.1-6. 2010.

Vetvicka, V. Glucan-immunostimulant, adjuvante, potential drug. World Journal of Clinical Oncology, v.10,n.2,p.115-119. 2011.

Vetvicka V. e Vetvickova J. Comparison of immunological effects of commercially available $\beta$-glucans. Applied Scientific Reports, v.1:p.2-7. 2014 a.

Vetvicka V e Vetvickova J. Immune-enhancing effects of Maitake (Grifola frondosa) and Shiitake (Lentinula edodes) extracts. Annals of Translational Medicine, v.2,n.2,p.1-14. $2014 \mathrm{~b}$

Viana, S.R.F. Comportamento agronômico e caracterização bioquímica de linhagens de Ganoderma lucidum cultivadas em serragem. 2014. 66 f. Mestrado (Mestre em Agronomia). Universidade Estadual Paulista Júlio Filho - UNESP.

Vijai, K G. et al. Biotechnology of Bioactive Compounds. Sources and applications. 1 ed. Editora. Wiley. f.736. 2015.

Villena, J., Vizoso-Pinto, M.G. e Kitazawa, H. Intestinal innate antiviral immunity and immunobiotics: benefical effects against rotavirus infection. Frontiers in Immunoloy, v.7,p.563. 2016.

Voelz, K.; Lammas, D.A. e May, R.C. Cytokine signaling regulates the outcome of intracellular macrophage parasitism by Cryptococcus neoformans. Infection and Immunity, v.77,p.3450-3457. 2009.

Voelz, K. e May, R.C. Cryptococcal interactions with the host immune system. Eukaryotic Cell, v.9,n.6, p.835-46. 2010.

Vogel, L.K. et al. Intestinal PTGS2 mRNA levels, PTGS2 gene polymorphism, and colorectal carcinogenesis. PLoS One, v.9,n.8,p.e105254. 1-8. 2014.

Volman, J.J. et al. Effects of mushroom-derived $\beta$-glucan-rich polysaccharide extracts on nitric oxide production by bone marrow-derived macrophages and nuclear factor- $\mathrm{k} B$ transactivation in Caco-2 reporter cells: Can effects be explained by structure? Molecular Nutrition \& Food Research, v.54,p.268-76. 2010.

Walton, F.J.; Idnurm, A. e Heitman, J. Novel gene functions required for melanization of the human pathogen Cryptococcus neoformans. Molecular Microbiology, v.57,p. 13811396. 2005. 
Wang, C.H. et al. Concentration variation and molecular characteristics of soluble $(1,3 ; 1,6)-\beta$-D-glucans in submerged cultivation products of Ganoderma lucidum mycelium. Journal of Agricultural and Food Chemistry, v.62,p.634-641. 2014.

Wang, C.L. et al. Extracellular polysaccharides produced by Ganoderma formosanum stimulate macrophage activation via multiple pattern-recognition receptors. BMC Complementary and Alternative Medicine, v.12,n.119,p.1-10. 2012.

Wan-Monhtar, W.A.A.Q.I., Malek, R.A. Harvey, L.M. e McNeil, B. Exopolysaccharide production by Ganoderma lucidum immobilized on polyurethane foam in a repeatedbatch fermentation. Biocatalysis and Agricultural Biotechnology, v.8,p.24-31.2016.

Wellington, M. et al. Candida albicans triggers NLRP3-mediated pyroptosis in macrophages. Eukaryotic Cell, v.13,n.2,p.329-340. 2014.

Wasser, S.P. Medicinal mushroom science: history, current status, future trends, and unsolved problems. International Journal of Medicinal Mushrooms, v.12,n.1,p.01-16. 2010.

Wasser, S.P. Current findings, future trends, and unsolved problems in studies of medicines mushroom. Applied Microbiology and Biotechnology, v.89,p.1323-1332. 2011.

Wasser, S.P. Medicinal mushroom science: current perspectives, advances, evidences, and challenges. Biomedical Journal, v.37,n.6,p.345-56. 2014.

Wei, W.C. et al. GM-CSF plays a key role in zymosan-stimulated human dendritic cells for activation of Th1 and Th17 cells. Cytokine, v.55,p.79-89. 2011.

Wessels, J. e Siestma, J. Fungal cell walls: a survey. In Tanner W, Loewus F. (Eds.) Encyclopedia of Plant Physiolog. New Series, Plant Carbohydrates I. Berlin: SpringerVerlag.13B 352-394. 2. 1982.

Wilber, R.H. et al. Physical interaction of T cells with dendritic cells not required for the immunomodulatory effects of the edible mushroom Agaricus subrufescens. Frontiers in Immunology, v.7,n.519,p.ecollection. 2016.

Williams, D. L. et al. Modulation of the phosphoinositide 3-kinase pathway alters innate resistance to polymicrobial sepsis. Journal of Immunology, v.172,p.449-456. 2004.

Willment, J. A. et al. The human $\beta$-glucan receptor is widely expressed and functionally equivalent to murine dectin-1 on primary cells. European Journal of Immunology, v.35,p.1539-1547. 2005.

Woo, C.W. et al. Ganoderma lucidum inhibits inducible nitric oxide synthase expression. In macrophages. Molecular and Cellular Biochesmitry, v.27,n.275(1-2),p.165-171. 2005.

Wozniak, K.; Vyas, J. e Levitz, S. In vivo role of dendritic cells in a murine model of pulmonary cryptococcosis. Infection and Immunity, v.74,n.7,p.3817-3824. 2006. 
Wu, J., Ding, Z.Y., Zhang, K.C. Improvement of exopolysaccharide production by macro-fungus Aricularia auricula in submerged culture. Enzyme and Microbial Technology, v.39p.743-749. 2006.

Yang, W.J. et al. Enhancing immunomodulatory and antioxidant functions of superfine edible mushroom flour. Mycosysntema, v.34.n.2,p.301-310. 2015.

Yao, V. et al. Zymosan induces nitric oxide production by peritoneal mesothelial cells. Surgical Research, v.74,p.266-269. 2004.

Xie, G. et al. Fractionation and characterization of biologically-active polysaccharides from Artemisia tripartita. Phytochemistry, v.69,p.1359-1371. 2008.

Xie, J. et al. Laminarin-mediated targeting to dectin-1 enhances antigen-specific immune responses. Biochemical and Biophysical Research Communications, v.391,p.958-962. 2010.

Xu, C.P., Kim, S.W., Hwang, H.J., Yun, J.W. Application of statistically based experimental designs for the optimization of exo-polysaccharide production by Cordyceps militaris NG3. Biotechnology and Applied Biochemistry, v.36,p.127-131. 2002.

$\mathrm{Xu}, \mathrm{Q}$. et al. Role od dectin-1 in the innate immune response of rat corneal ephitelial cells to Aspergillus fumigatus. BMC Ophthalmology, v.15,n.126,p.1-7. 2015.

$\mathrm{Xu}$, S. e Zhang, Y. Antioxidant activity in vitro and in vivo of the polysaccharide from different varieties of Auricularia auricula. Food \& Function, v.14,n.9,p.3868-79. 2016.

$\mathrm{Xu}, \mathrm{X}$. , Yan, H., e Zhang, X. Structure and immuno-stimulating activities of a new heteropolysaccharide from Lentinula edodes. Journal of Agricultural and Food Chemistry, v.60,p.11560-11566. 2012.

Xu, Z. et al. Ganoderma lucidum polysaccharides: immunomodulation and potential antitumor activities. The American Journal of Chinese Medicine, v.39,n.1,p.15-17. 2011.

Zaragoza, O. et al. The polysaccharide capsule of the pathogenic fungus Cryptococcus neoformans enlarges by distal growth and is rearranged during budding. Molecular Microbiology, v.59,p.67-83. 2006.

Zaragoza, O. et al. Capsule enlargement in Cryptococcus neoformans confers resistance to oxidative stress suggesting a mechanism for intracellular survival. Cellular Microbiology, v.10,p.2043-2057. 2008.

Zaragoza, O. The capsule of the fungal pathogen Cryptococcus neoformans. Advances in Applied Microbiology, v.68,p.133-216. 2009.

Zaragoza, O. Multiple disguises for the same party: the concepts of morphogenesis and phenotypic variations in Cryptococcus neoformans. Frontiers in Microbiology, v.2,p.181. 2011. 
Zekovic, D.B., et al. Natural and modified (1-3)-beta-D-glucans in health promotion and disease alleviation. Critical Reviews in Biotechnology, v.25,n.4,p. 205-30. 2005.

Zhang, H. et al. Purified Auricularia auricular-judae polysaccharide (AAP I-a) prevents oxidative stress in an ageing mouse model. Carbohydrate Polymers, v.84,n.1,p.638348. 2011.

Zhang, M. et al. Antitumor polysaccharide from mushrooms: a review on their isolation process, structural characteristics and antitumor activity. Trends in Food Science \& Technology, 18, 4-19, 2007.

Zhang, R. e Edgar, K. Properties, Chemistry, and Applications of the Bioactive Polysaccharide Curdlan. Biomacromolecules, v.15, p.1079-1096. 2014.

Zhao, G.Q. et al. The role of Dectin-1/Raf-1 signal cascade in innate immune of human corneal epithelial cells against Aspergillus fumigatus infection. International Journal of Ophthalmology, v.9,n10,p.1371-75. 2016.

Zhao, Q. et al. Physicochemical properties and regulatory effects in $\mathrm{db} / \mathrm{db}$ diabetic mice of $\beta$-glucans extracted from oat, wheat and barley. Food Hydrocolloids, v.37,p.60-68. 2014.

Zhong, D. et al. Ganoderma lucidum polysaccharide peptide prevents renal ischemia reperfusion injury via counteraxting oxidative stress. Scientific Reports, v.5,n.16910,p.1-14. 2015.

Zhu, C.C. et al. Dectin-1 agonist curdlan modulates innate immunity to Aspergillus fumigatus in human corneal epithelial cells. International Journal of Ophthalmology, v.8,n.4,p.6906. 2015.

Zhu, L.L. et al. C-type lectin receptors Dectin-3 and Dectin-2 form a heterodimeric pattern-recognition receptor for host defense against fungal infection. Immunity, v.39,p.324-334. 2013.

Zhu, R., Chen, X. e Lan, J. Advance in the study on liquid fermentation for medicinal fungi. Journal of Chinese Medicinal Material, v.26,n.1,p.55-7. 2003.

Zhu, X.L., Chen, A.F. e Lin, Z.B. Ganoderma lucidum polysaccharides enhance the function of immunological effector cells in immunosuppressed mice. Journal of Ethnopharmacology, v.111,n.2,p.219-226. 2007.

Zied, D.C. Influence of productivity and processing method on physicochemical characteristics of white button mushrooms in Brazil. Journal of the Science of Food Agriculture, v.94,n.14,p.2850-5. 2014.

Zuo, J.C. et al. Effect of Auricularia auricula polysaccharide on PBMCs proliferation and cytokine expression in vitro. Journal of Chinese Medicinal Materials, v.31,n.1,p.76-79. 2008. 
Zygmunt, B. e Veldhoen, M. T helper cell differentiation. More than just cytokines. Advances in Immunology, v.109,p.159-196. 2011. 


\section{ANEXO 9.1. AUTORIZAÇÃO DE ACESSO AO BANCO DE GERMOPLASMA DE COGUMELOS.}

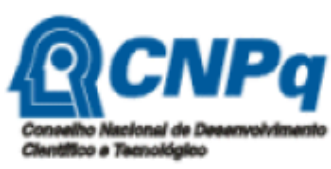

4386058045266733

\section{AUTORIZAÇÃO DE ACESSO E DE REMESSA DE AMOSTRA DE COMPONENTE DO PATRIMONIO GENETICO ${ }^{\circ}$ 010342/2014-1}

O CONSELHO NACIONAL DE DESENVOLVIMENTO CIENTÍFICO E TECNOLÓGICO - CNPq, credenciado pelo Conselho de Gestão do Patrimônio Genético (CGEN/MMA), por meio da Deliberação CGEN n ${ }^{\circ} 246$, de 27 de agosto de 2009 , para autorizar instituiç̧̃es nacionais, públicas ou privadas, que exerçam atividades de pesquisa e desenvolvimento nas áreas biológicas e afins, a acessar e remeter amostras de componente do patrimônio genético para fins de pesquisa científica sem potencial de uso econômico, neste ato representado pelo seu Diretor de Ciências Agrárias, Biológicas e da Saúde, nos termos da Portaria CNPq n 104/2011, autoriza a instituição abaixo qualificada a acessar e remeter amostras de componentes do patrimônio genético.

Instituição: UNIVERSIDADE DE BRASILIA - UNB

CNPJ: 000.381.740/0001-43

Representante Legal: JAIME MARTINS DE SANTANA

Cargo/Função: Decano (Pró-Reitor) de Pesquisa e Pós-Graduação

CPF: $308.595 .651-49$ RG: 358372

Projeto: Avaliação do potencial imunomodulador in vitro e in vivo de beta;-glicanas extraídas dos fungos basidiomicetos Auricularia auricular e Ganoderna lucidum

Coordenador do Projeto: Anamélia Lorenzetti Bocca

CPF: 093.874.008-32 RG: 10482487 - SSP / SP

Finalidade do projeto: Os cogumelos são importantes fontes de compostos bioativos e de impacto benéfico à saúde humana. Os compostos bioativos podem ser provenientes de corpos frutíferos, esporos e micélios. Os cogumelos das espécies Auricularia auricular e Ganoderma lucidium são importantes fontes de compostos biativos, principalmente beta-glicanas com ação imumoduladora envolvendo efeitos antitumoral e antimicrobiano. As beta-glicanas são polímeros de glicose que fazem parte, como constituintes estruturais, da parede celular de diversas espécies fúngicas e bacterianas. Ocorrem diversas variações estruturais nas beta-glicanas dessas diferentes fontes, que podem influenciar em sua bioatividade. De fato, estudos in vitro e in vivo em animais e humanos indicam que especialmente beta-glicanas provenientes de leveduras e cogumelos têm propriedades de modulação do sistema imunológico. O principal receptor envolvido no reconhecimento de \#-glicana é Dectina-1 presente principalmente nas células do sistema imunológico inato como macrófagos e células dendriticas. Diversos trabalhos demonstram um papel importante na imunidade antifúngica mediada por dectina-1 ao reconhecer beta-glicanas. Camundongos deficientes para esse receptor demonstram suscetibilidade elevada para C. albicans, A. fumigattus e Pneumocystis carinii devido à resposta inflamatória e destruição fúngica insuficientes. Ademais, indivíduos homozigotos para um polimorfismo na dectina-1 em humanos (Y238X), o que impede a expressão desse receptor na membrana plasmática, são suscetíveis a infecções muco-cutâneas por $\mathrm{C}$. albicans e Trichophyton rubrum. Nesse contexto, e considerando a experiência do grupo no tema de projeto proposto, o objetivo da presente proposta é selecionar beta-glicanas de diferentes cogumelos nutracêuticos que apresentem as melhores respostas na modulação do sistema imunológico do hospedeiro murino e avaliar a eficácia da dessas beta-glicanas nanoencapsulada com o antifúngico fluconazol para o tratamento da infecção causada pelo patógeno Paracoccidioides brasilinensis. Esse fungo é o causador da paracoccidioidomicose, a micose sistêmica de maior prevalência na America Latina, principalmente Brasil. O fluconazol é um dos medicamentos antifúngicos mais utilizados devido ao baixo custo e um amplo espectro de ação contra várias espécies de fungos patogênicos. Porém, o tratamento de doenças fúngicas à base de fármacos convencionais pode resultar: (i) diversos efeitos colaterais (devido a sua toxicidade) ; (ii) na incapacidade em reverter à imunossupressão descrita em diversas micoses e (iii) no surgimento de cepas resistentes. Dessa maneira, a utilização da nanotecnologia como um sistema de distribuição sustentável poderia ser utilizada junto a fármacos, como fluconazol e ao polissacarídeo beta glicana, para assim controlar a carga fúngica de forma mais eficiente e menos toxica, além de auxiliar no restabelecimento da resposta imune do hospedeiro.

\section{Amostras a serem acessadas:}

Grupos Taxonômicos: Ganoderna lucidium e Auricularia auricular

Tipo de material/quantidade de amostras: não se aplica

Local de depósito de subamostra: EMPRESA BRASILEIRA DE PESQUISA AGROPECUARIA

Equipe do projeto: ANAMELIA LORENZETTI BOCCA / CPF 093.874.008-32

ALDO HENRIQUE FONSECA PACHECO TAVARES / CPF 795.110.151-68

MARCIO SOUSA JERONIMO / CPF 035.187.734-70 


\section{ANEXO 9.2. ANÁLISES ADICIONAIS DAS FRAÇÕES DE $\boldsymbol{A}$. auricula}

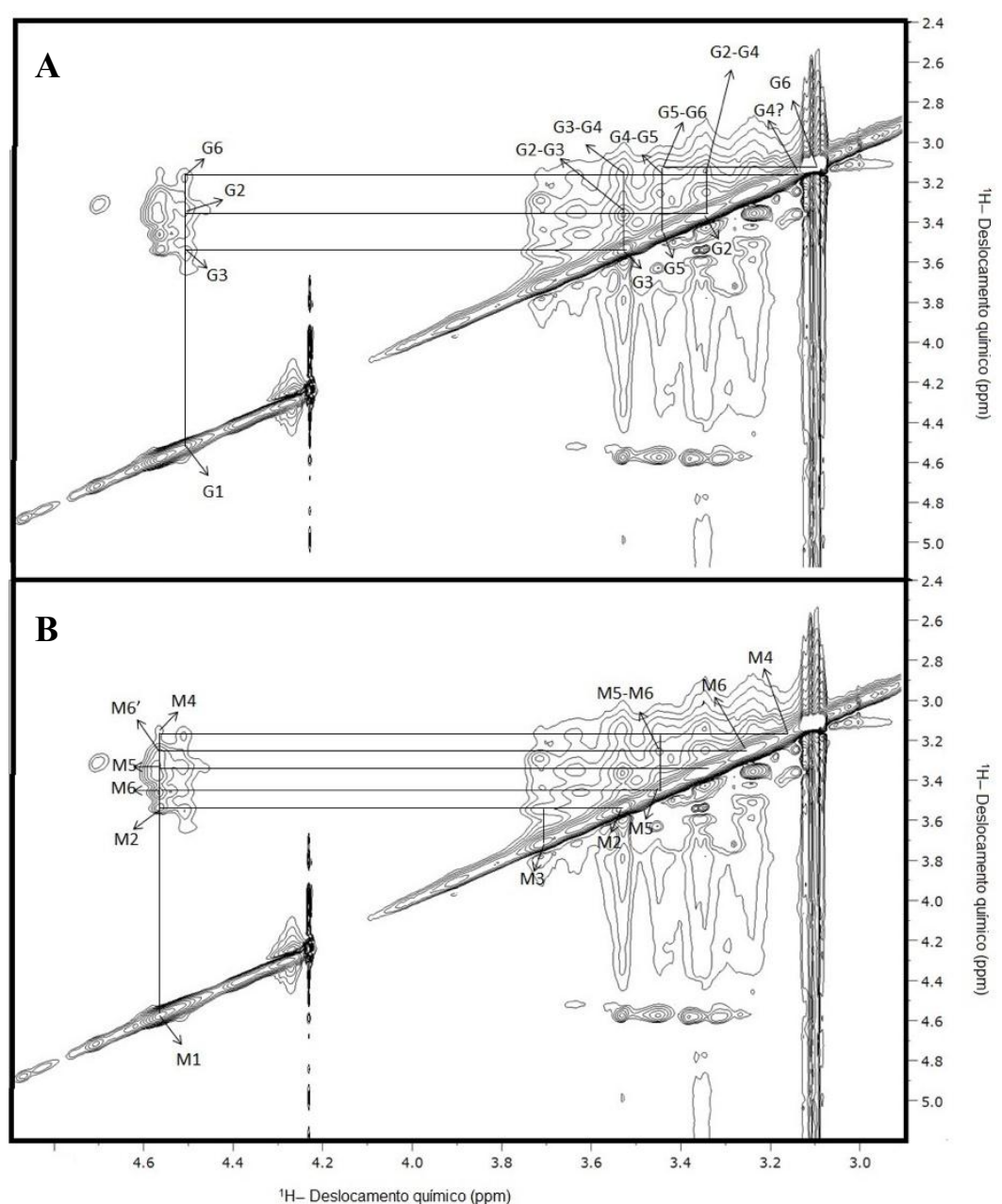

Figura 1. Espectro 2D- ${ }^{1} \mathrm{H}-{ }^{1} \mathrm{H}$ NOESY de RMN da fração solúvel de $A$. auricula. ( $\delta_{\mathrm{H}}: 4.9$ a $\left.2.1 \mathrm{ppm}\right)$. (A) - espectro da amostra com os assinalamentos feitos para os resíduos de Glc $p(\mathrm{G})$. (B) assinalamentos obtidos para os resíduos de Manp (M). O número após a letra refere-se ao ${ }^{1} \mathrm{H}$ respectivo no anel glicosídico. Os espectros foram gravados em um espectrômetro Bruker $500 \mathrm{MHz}$ Avance III a $298 \mathrm{~K}$. 


\section{ANEXO 9.3. ESPECTRO 1D- ${ }^{1}$ H DE RMN DA FRAÇÃO SOLÚVEL DE A. auricula}

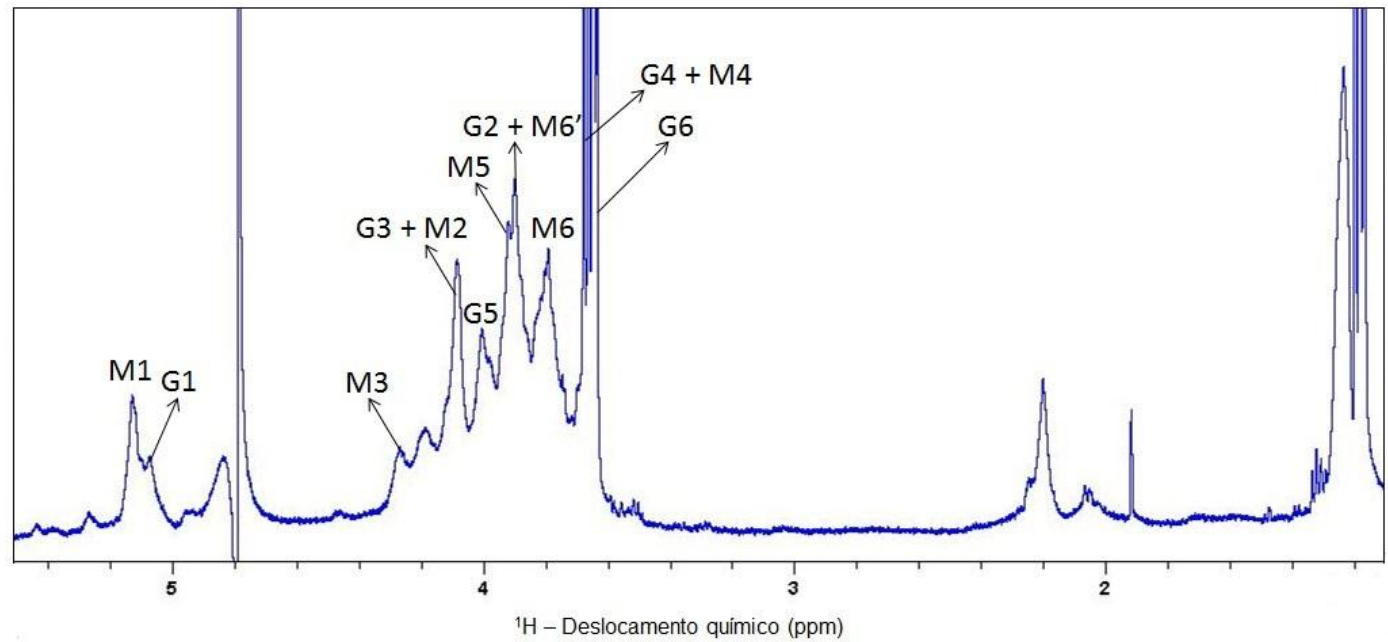

Figura 1. Espectro $1 \mathrm{D}-{ }^{1} \mathbf{H}$ de RMN da fração solúvel de $\boldsymbol{A}$. auricula. $\left(\delta_{\mathrm{H}}: 5.6\right.$ a $\left.1.0 \mathrm{ppm}\right)$. As letras M e $\mathrm{G}$ indicam as unidades de Man $p$ e Glc $p$, respectivamente. Os espectros foram gravados em um espectrômetro Bruker $500 \mathrm{MHz}$ Avance III a $298 \mathrm{~K}$.

ANEXO 9.4. TABELA DE DESLOCAMENTOS QUÍMICOS DA FRAÇÃO SOLÚVEL DE A. auricula.

\begin{tabular}{|c|c|c|c|c|c|}
\hline Açúcar & Unidade & $\begin{array}{l}{ }^{1} \mathrm{H} /{ }^{13} \mathrm{C} \\
\text { (ppm) }\end{array}$ & Açúcar & Unidade & $\begin{array}{l}{ }^{1} \mathrm{H} /{ }^{13} \mathrm{C} \\
\text { (ppm) }\end{array}$ \\
\hline \multirow{7}{*}{$\begin{array}{l}1 \rightarrow 2,6 \alpha-D- \\
\operatorname{Manp}(1 \rightarrow\end{array}$} & M1 & $4,56 / 108,02$ & \multirow{7}{*}{$\begin{array}{c}1 \rightarrow 6 \text { 林-Glcp } \\
(1 \rightarrow\end{array}$} & G1 & $4,52 / 103,60$ \\
\hline & M2 & $3,53 / 74,00$ & & G2 & $3,32 / 78,04$ \\
\hline & M3 & $3,71 / 72,70$ & & G3 & $3,53 / 75,83$ \\
\hline & M4 & $3,12 / 72,47$ & & G4 & $3,12 / 72,41$ \\
\hline & M5 & $3,37 / 73,16$ & & G5 & $3,44 / 77,12$ \\
\hline & M6 & $3,34 / 66,76$ & & G6 & $3,10 / 63,18$ \\
\hline & M6' & $3,22 / 66,16$ & & G6' & $N D^{*}$ \\
\hline
\end{tabular}

Tabela 1. Tabela demonstrando os deslocamentos químicos dos principais constituintes da amostra AS com base nos deslocamentos químicos de ${ }^{1} \mathrm{He} \mathrm{e}^{13} \mathrm{C}$ obtidos do ${ }^{1} \mathrm{H}-{ }^{13} \mathrm{C}$ HSQC obtidos da figura 5 para Man $p(\mathrm{M})$ e Glcp $(\mathrm{G})$ e as possíveis ligações destes carboidratos. 


\section{ANEXO 9.5 HiSTOGRAMA do ENSAIO de AVALIAÇÃO DE EXPRESSÃO dAS MOLÉCULAS CO-ESTIMULATÓRIAS CD80, CD86 E MHC II.}

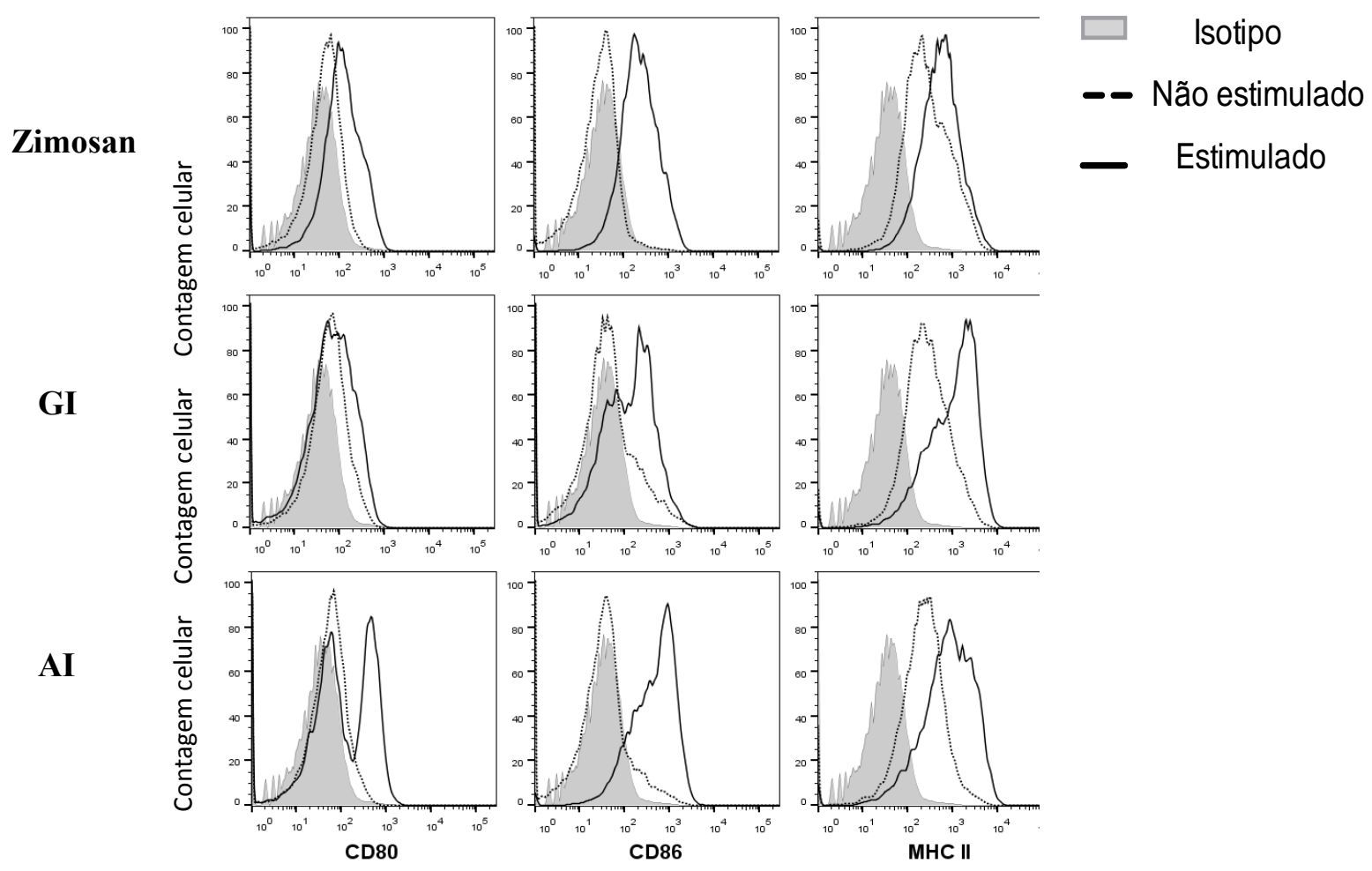

Figura 1. Histograma da fenotipagem de células dendríticas estimuladas com polissacarídeos de $\boldsymbol{A}$. auricula e G. lucidum positivas para os receptores CD80, CD86 e MHC II. DC - Células dendríticas, Zim - zimosan não depletado, GI - Ganoderma lucidum fração insolúvel, AI - Auricularia auricula fração insolúvel; Concentração de $100 \mu \mathrm{g} / \mathrm{mL}$ para todas as amostras testadas; MHC II - complexo de histocompatibilidade tipo II, Isotipo CD11 $\mathrm{b}^{+}$. Histograma demonstra a fluorescência no eixo horizontal (em unidade exponencial logarítmica) e a quantidade de células dendríticas contadas no eixo vertical; Experimento realizado em triplicata biológica. 


\section{ANEXO 9.6. ESTRATÉGIA DE SELEÇÃO DA FENOTIPAGEM DE CÉLULAS DENDRÍTICAS.}

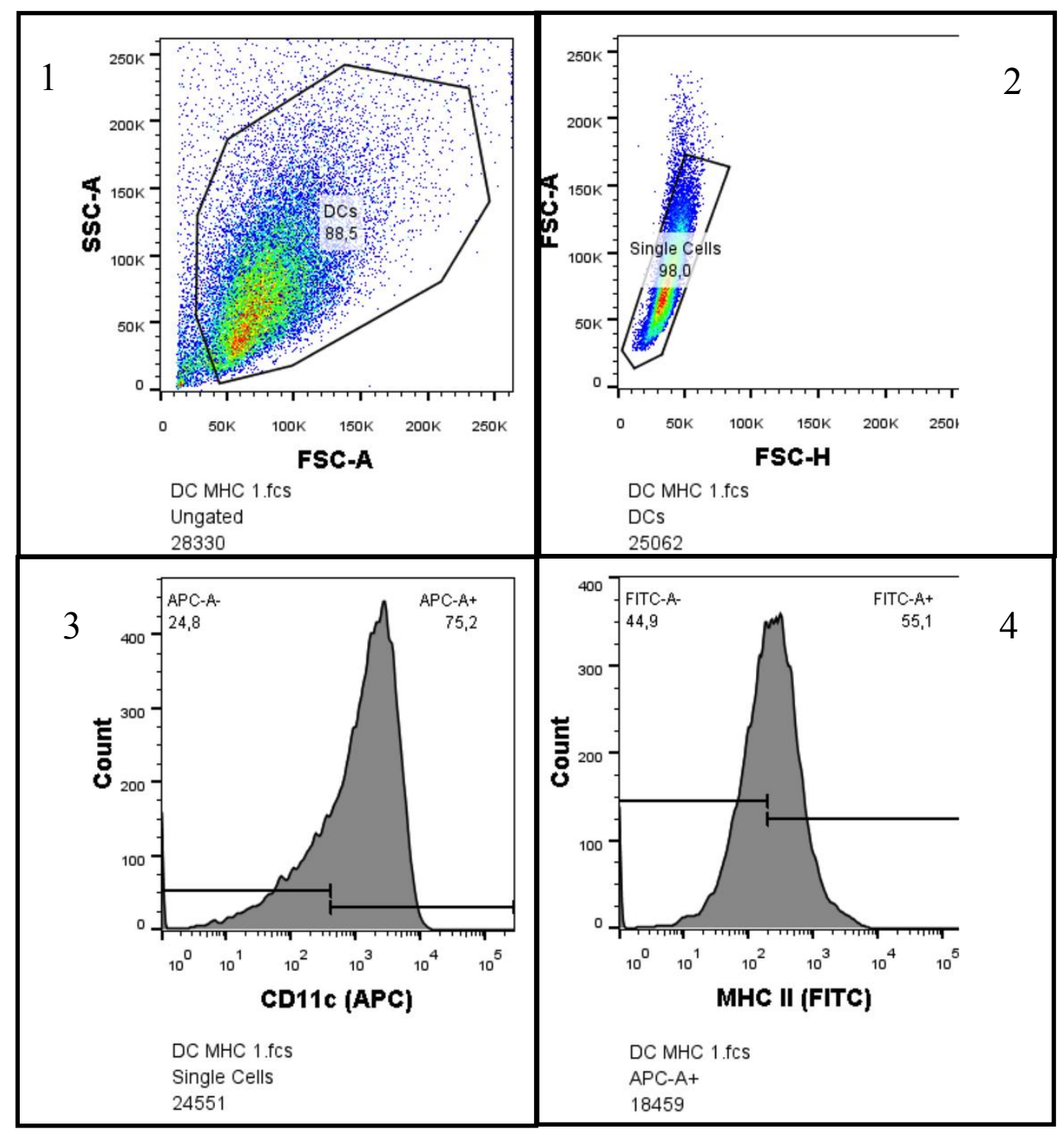

Figura 1. Estratégia de seleção usado para análise de fenotipagem de CD80, CD86 e MHC II. Para a estratégia de seleção de células positivas foram (1) selecionadas população de células de acordo com tamanho e granulosidade para o tipo celular (BMDC) (SSC-A vs FSC-A), (2) excluídos os doublets (grumos de células) (FSC-A vs FSC-W), (3) selecionados células positivas para o marcador de identificação $\mathrm{CD} 11 \mathrm{c}^{+}$, (4) o mesmo parâmetro e utilizado para todos os tratamentos. 


\section{ANEXO 9.7 HISTOGRAMA DA ANÁLISE DA PRODUÇÃO DE ESPÉCIES REATIVAS DE OXIGÊNIO.}
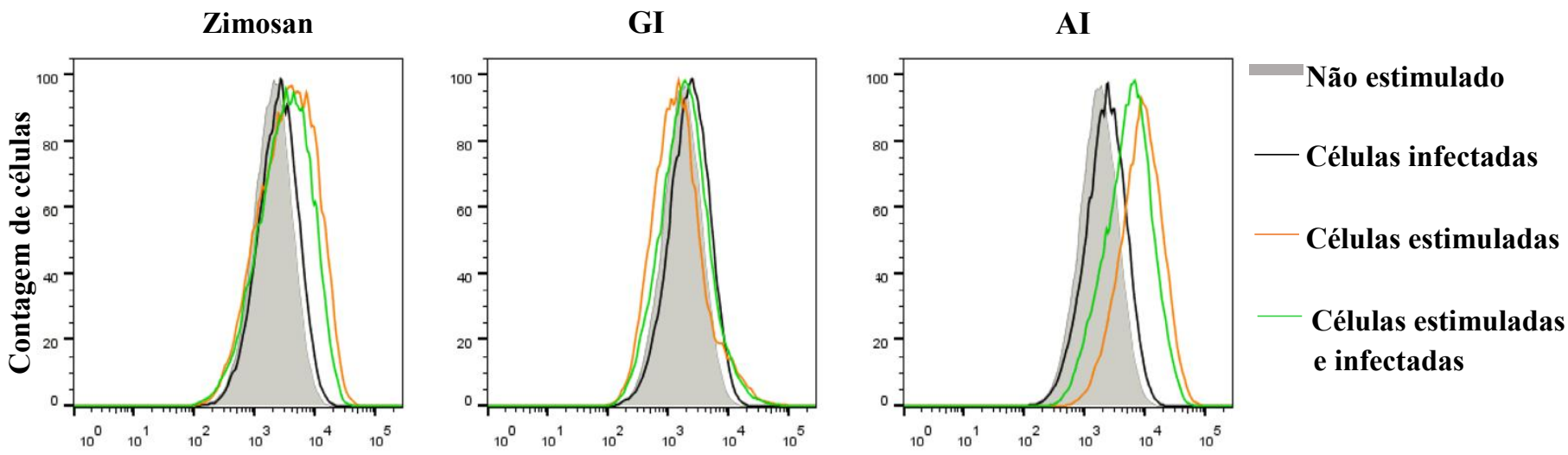

Células positivas para EROs

Figura 1. Histograma da produção de espécies reativas de oxigênio (EROs) por células M2 antes e durante infecção de $C$. neoformans após estímulo de polissacarídeos de A. auricula e G. lucidum. O tempo de estímulo dos polissacarídeos foi de 12 horas; Tempo de infecção após estímulo com polissacarídeos foi de 2 horas; Zim - zimosan não depletado, GI - Ganoderma lucidum fração insolúvel; AI - Auricularia auricula fração insolúvel; Concentrações de todos os estímulos foi de $100 \mu \mathrm{g} / \mathrm{mL}$; M2 macrófagos alternativamente ativados; (A) histograma demonstra a fluorescência no eixo horizontal (em unidade exponencial logarítmica) e a quantidade de macrófagos alternativamente ativados (M2) contadas no eixo vertical; Experimento realizado em triplicata biológica. 


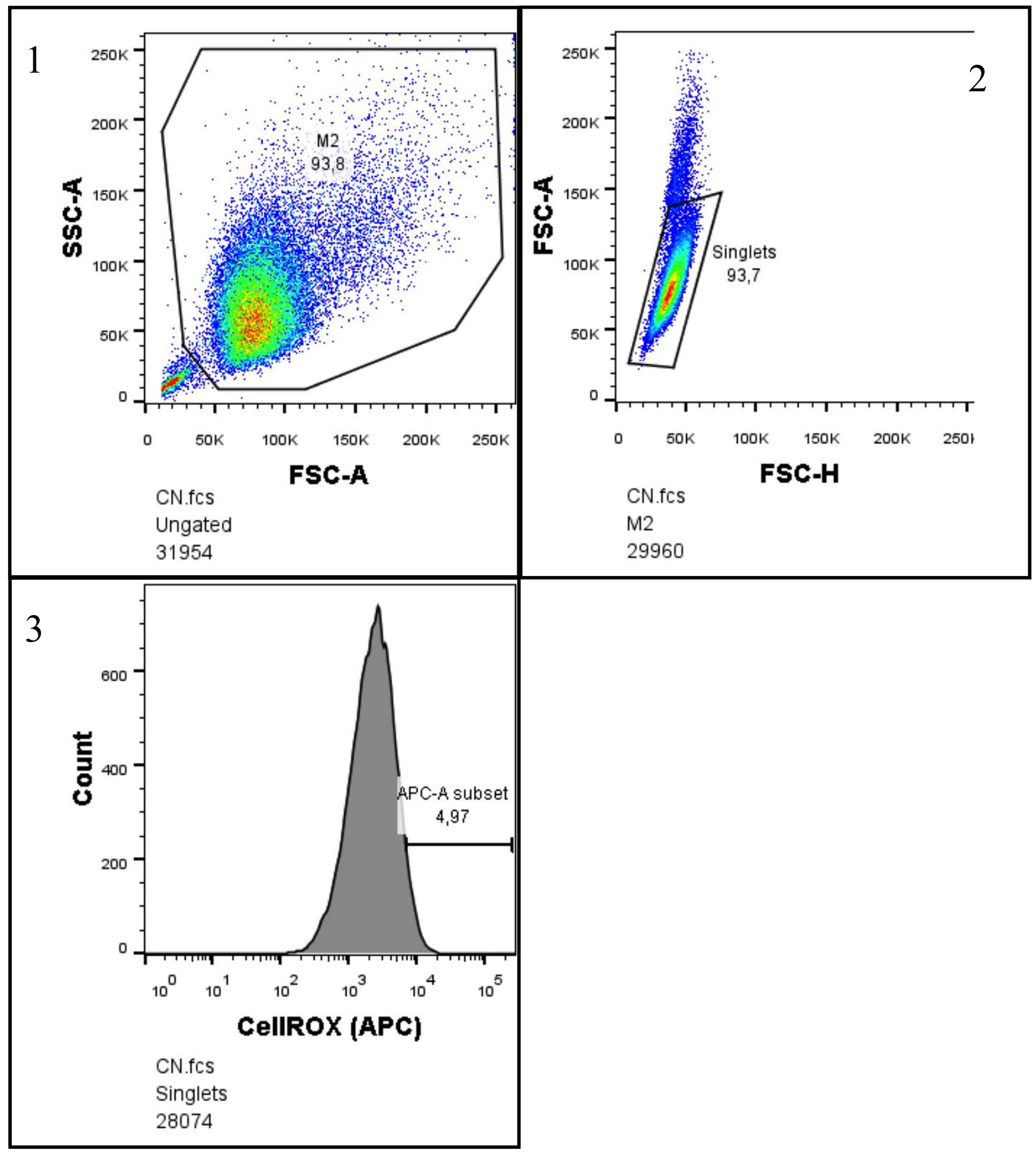

Figura 1. Montagem da estratégia de seleção para avaliação da produção de EROs em macrófagos M2. Para a estratégia de seleção de células positivas foram (1) selecionadas população de células de acordo com tamanho e granulosidade para o tipo celular (BMDC) (SSC-A vs FSC-A), (2) excluídos os doublets (grumos de células) (FSC-A vs FSC-W) e (3) selecionados células positivas para o marcador de identificação CD11 $\mathrm{c}^{+}$(Anexo 9.6). 


\section{ANEXO 9.9 AUTORIZAÇÃO COMITÊ DE ÉTICA PARA USO DE ANIMAIS}

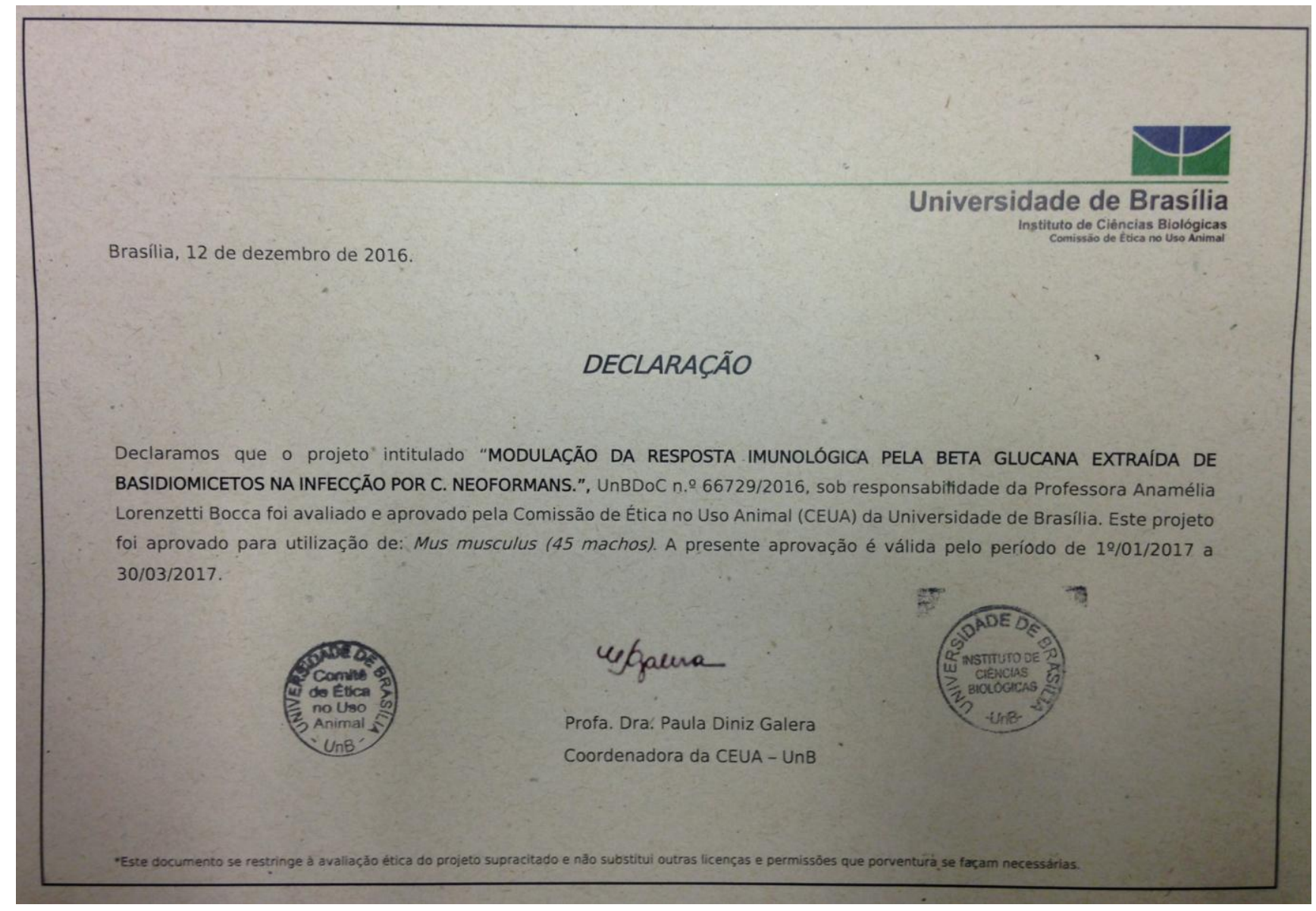

\section{PUBLICAÇÕES DO ALUNO}

\section{Artigo relacionado a tese}

Basso, A.M.M.; Castro, R.J.A.; Jeronimo, M.S.; Carbonero, E.R.; Queiroz, I.L.N; Pomim, V.H.; Tavares, A.H.; Grossi de Sá, M.F., Bocca, A.L. IMMUNOLOGICAL ACTIVATION BY BASIDIOMYCETES POLYSACCHARIDES AND APPLICATION IN $C$. neoformans EXPERIMENTAL INFECTION. Frontiers in Immunology, EM PREPARAÇÃO. 


\title{
Outras publicações.
}

\section{Biopharmaceutical and Biosimilar Products in Brazil: From Political To Biotechnological Overview}

\author{
Angelina M. M. Basso ${ }^{1}$, Maria Fátima Grossi de Sá ${ }^{1}$ and Patrícia B. Pelegrini ${ }^{2 *}$
}

'Embrapa - Genetic Resources and Biotechnology, PqEB Av. W5, Asa Norte, Cx. Postal 02372, Brasilia - DF, Brazil ${ }^{2}$ BioLife Brasil Ltda., Distrito Agroindustrial de Formosa, Quadra 01, Lotes 19 e 20, Formosa - GO, Brazil

\begin{abstract}
According to the World Health Organization (WHO), one third of the world's population don't have the necessary access to pharmaceutical products, including essential drugs. In Brazil, the Governmental Health System (SUS) distributes some medicaments for free to the population. They were, then, classified into three categories in the country: basic, strategic and specialized components. Among these categories, the last one is highlighted due to the expensive costs of its products, which are essential for the treatment of rare and specific diseases. For this reason, the Ministry of Health created, in 1993, the Program for Specialized Medicaments, where all the drugs included in this category were distributed for free through Clinics and Hospitals. During the first year of this Program's implementation, there were 15 different items distributed into 31 distinct presentations. Nowadays, the list expanded to 150 different items dispensed into 310 presentations. Hence, the availability of imported pharmaceutical products in Brazil overloaded the expenses by the Brazilian Ministry of Health. Only during 2011, US\$1.5 billion were spent on these products, where $30 \%$ of this amount was related to specialized ones. In order to reduce costs, the Brazilian Federal Government developed, in 2004, the Technological Innovation Law. According to the Decree number 6.041, the National Politics for Biotechnology and the National Committee of Biotechnology were created in order to stimulate the development of Biotechnology for human health, targeting mainly the national production of biopharmaceuticals. Furthermore, the end of patents for several medicaments during the last 5 years enhanced the motivation for national production of new drugs. In this way, some Governmental Institutions, in partnership with International Pharmaceutical Industries, started developing the first biosimilar molecules. Therefore, this report describes the evolution of Biotechnology in Brazil, relating the laws, regulations and Programs created along the last 20 years for Human Health application.
\end{abstract}

Keywords: Brazil; Biotechnology; Biopharmaceuticals; Biosimilars; Regulations

\section{Introduction}

The use of pharmaceutical compounds for treatment of several diseases has been described for more than 3000 years. However, only during the last century that pharmaceuticals started being produced in large scale by the properly named "Pharmaceutical Industries". Improvements in science, such as the discovery of penicillin for production of antibiotics, and advances on recombinant DNA ( $\mathrm{rDNA})$ and hybridome allowed the development of Biotechnology and new techniques applied on the production of more efficient pharmaceuticals.

Nowadays, the production of biological medicaments occurs by companies with Biotechnology application and also by traditional pharmaceutical industries, or even by a partnership between them. due to investments by the Government for national production of such medicaments, as well as due to the enhancement of partnerships between Public Research Institutions and Private Companies. Only until 2008, there were 12 Biopharmaceutical companies registered at ANVISA, 8 of each where national ones: Aché, Blausiegel, Cristália, Eurofarma, Fiocruz, Prodotti and Silvestre Lab [4].

Moreover, the increasing expenses by the Ministry of Health with imported medicaments have motived the Government to invest on the national production of many biosimilar drugs. In 2011, the Brazilian Government spent US $\$ 4.9$ billion on the importation of medicaments [5], and among them, 8 biopharmaceuticals imported represented $18 \%$ of the total costs, including: philgastim, glucagon, growth hormones, human recombinant insulin, $\alpha$-interferon, $\beta$-interferon and somathrophin. For this reason, the development of biosimilar molecules in Brazil can be seen as a strategy for the improvement of Brazilian Biopharmaceutical Industries. In addition, the market for 


\title{
Recombinant glucagon: a differential biological activity
}

Angelina M M Basso ${ }^{1,2}$, Patrícia B Pelegrini ${ }^{2}$, Fernanda Mulinari ${ }^{2,3}$, Michelle C Costa $^{2}$, Antonio B Viana ${ }^{2,4}$, Luciano P Silva ${ }^{5}$ and Maria Fatima Grossi-de-Sa, ${ }^{2,4^{*}}$

\begin{abstract}
In Brazil, there is a growing demand for specialised pharmaceuticals, and the high cost of their importation results in increasing costs, reaching US\$ 1.34 billion in 2012 and US\$ 1.61 billion in 2013. Worldwide expenses related to drugs could reach US\$ 1.3 trillion in 2018, especially due to new treatments for hepatitis C and cancer. Specialised or high-cost pharmaceutical drugs used for the treatment of viral hepatitis, multiple sclerosis, HIV and diabetes are distributed free of charge by the Brazilian government. The glucagon peptide was included in this group of high-cost biopharmaceuticals in 2008. Although its main application is the treatment of hypoglycaemia in diabetic patients, it can also be used with patients in an alcoholic coma, for those patients with biliary tract pain, and as a bronchodilator. Therefore, in order to reduce biopharmaceutical production costs, the Brazilian government passed laws focusing on the development and increase of a National Pharmaceutical Industrial Centre, including the demand for the national production of glucagon. For that reason and given the importance and high cost of recombinant glucagon, the purpose of this study was to develop methods to improve production, purification and performance of the biological activity of recombinant glucagon. Glucagon was recombined into a plasmid vector containing a Glutathione S-transferase tag, and the peptide was expressed in a heterologous Escherichia coli system. After purification procedures and molecular analyses, the biological activity of this recombinant glucagon was examined using in vivo assays and showed a highly significant $(p<0.00001)$ and prolonged effect on glucose levels when compared with the standard glucagon. The experimental procedure described here facilitates the high level production of recombinant glucagon with an extended biological activity.

Keywords: Recombinant Glucagon; Peptide expression; Heterologous system; Enterokinase; GST tag; Biological activity
\end{abstract}

\section{Introduction}

The development of recombinant proteins has been extremely promising. In 2009, pharmaceutical industries spent US\$ 90 billion on the activity evaluation of 400 different drugs. Moreover, in 2012, more than 150 recombinant drugs were approved by FDA (Food and Drug Administration) regulators and/or by the European Medicine Agency (Huang et al. 2012). By 2017, it is expected that over 300 products will be in the biopharmaceutical market, with a value of about US\$ 109 billion and an expected growth of US\$ 166 billion (Ibarra Cabrera et al. 2013). Worldwide expenses related to drugs could reach US\$ 1.3 trillion in 2018, especially due to new treatments for hepatitis $C$ and cancer (Chen, 2014).

According to the World Health Organization, one third of the world's population has no regular access to essential medicines (Nowbike 2006; Blatt et al. 2012). In Brazil, the Government provides free, high-cost drugs to the population, which are classified into three different categories: basic, strategic and specialised. The specialised components are expensive, which limits access of the population to important medicines. Hence, in 1993, the Program for Specialized Medicaments (SM) became a prospective solution to this problem. However, most of these medicines are imported from other countries, 

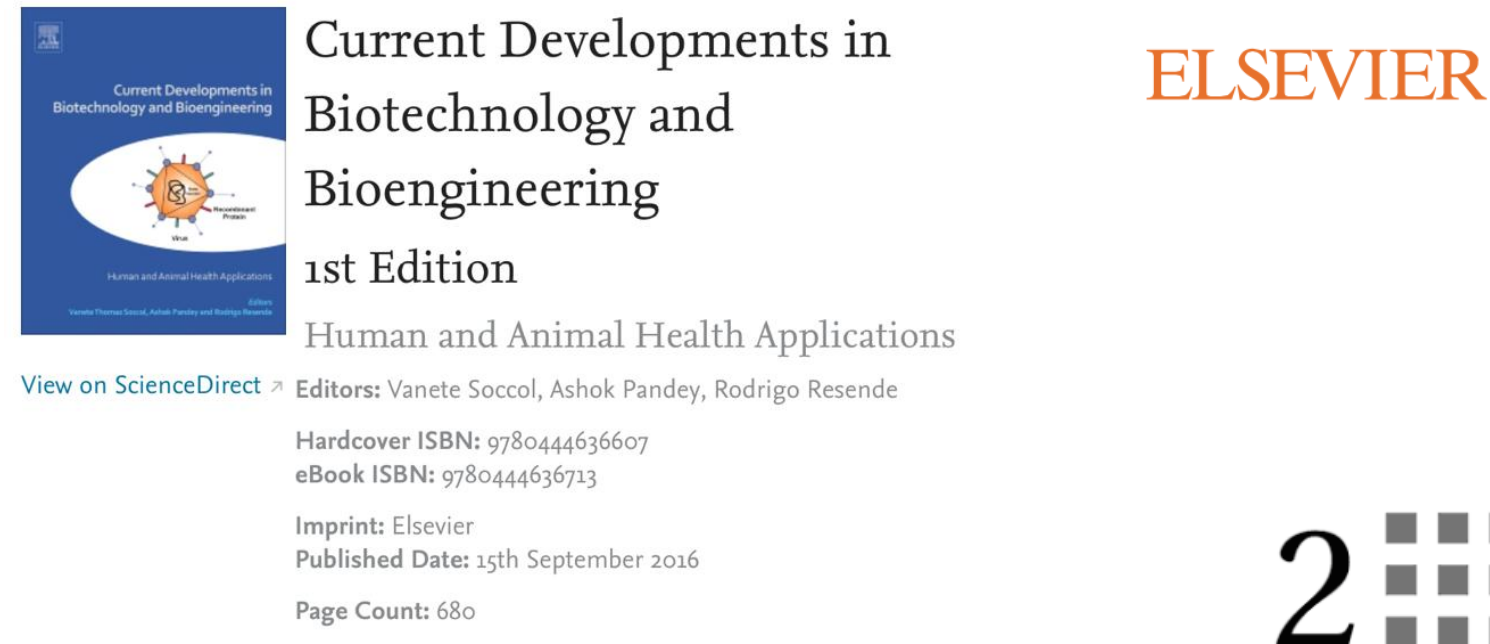

\title{
Biopharmaceuticals and Biosimilars
}

\author{
A.M.M. Basso ${ }^{1,3}$, G.S. Prado ${ }^{2,3}$, P.B. Pelegrini ${ }^{3,4}$, \\ M.F. Grossi-de-Sa ${ }^{2,3, *}$ \\ ${ }^{1}$ UNIVERSITY OF BRASILIA (UNB), BRASILIA-DF, BRAZIL; ${ }^{2}$ CATHOLIC UNIVERSITY \\ OF BRASILIA (UCB), BRASILIA-DF, BRAZIL; ${ }^{3} E M B R A P A-G E N E T I C ~ R E S O U R C E S$ \\ AND BIOTECHNOLOGY, BRASÍLIA-DF, BRAZIL; ${ }^{4}$ DIAGENE DIAGNÓSTICOS MOLECULARES \\ LTDA, BRASILIAA-DF, BRAZIL
}

\subsection{Introduction}

Until the 19th century, pharmaceuticals provided to the population were based on plantderived natural compounds and were applied in the form of infusions, teas, and creams. In 1885, Louis Pasteur attenuated the rabies virus in the laboratory and applied it to a boy who was bitten by a dog with rabies disease, thereby saving his life [1]. It was the first report of virus manipulation as medicine in the history of human health sciences.

Later, in 1928, Alexander Fleming developed the penicillin antibiotic. Immediately, pharmaceutical companies such as Pfizer, Squibb, and Merck tried to synthesize it for largescale production without success. Hence, the North Agriculture Regional Search Laboratory in the United States developed a methodology to produce penicillin but did not have a specific application. The need for the large-scale production of penicillin occurred during the Second World War (1939-45), because the number of American soldiers dying from bacterial infections and gangrene, accounting for $12-15 \%$ of all men. The administration of penicillin to wounded soldiers reduced mortality to $3 \%$, saving hundreds of lives $[2,3]$.

The post-Second World War period was the beginning of the biopharmaceutical industry, when the production of large-scale antibiotics started, as did the development of novel drugs from animal sources [4]. During the 1970s, researchers developed DNA recombinant technology, which facilitated the production of recombinant proteins. One of the first molecules produced by this technology was somatostatin [5]. Through genetic engineering techniques, the gene coding for somatostatin was inserted into Escherichia coli cells, which expressed a recombinant protein with activity similar to the human hormone [5]. In 1982, the same procedure was applied for the production and commercialization of the first recombinant insulin [6]. 